\author{
UNIVERSIDADE DE SÃO PAULO \\ FACULDADE DE FILOSOFIA, LETRAS E CIÊNCIAS HUMANAS \\ DEPARTAMENTO DE HISTÓRIA \\ PROGRAMA DE PÓS-GRADUAÇÃO EM HISTÓRIA SOCIAL
}

ELIEL WALDVOGEL CARDOSO

Relações Bilaterais entre o Brasil e a Venezuela (1983-1998)

Versão corrigida

São Paulo

2014 
UNIVERSIDADE DE SÃO PAULO

FACULDADE DE FILOSOFIA, LETRAS E CIÊNCIAS HUMANAS DEPARTAMENTO DE HISTÓRIA PROGRAMA DE PÓS-GRADUAÇÃO EM HISTÓRIA SOCIAL

ELIEL WALDVOGEL CARDOSO

Relações Bilaterais entre o Brasil e a Venezuela (1983-1998) Versão corrigida

ile Acordo Profa. Inaing Heleva 99. Cogelitro. S.Panlo, 16 de maio de 2014

São Paulo 2014 
UNIVERSIDADE DE SÃO PAULO

FACULDADE DE FILOSOFIA, LETRAS E CIÊNCIAS HUMANAS DEPARTAMENTO DE HISTÓRIA

PROGRAMA DE PÓS-GRADUAÇÃO EM HISTÓRIA SOCIAL

\section{Relações Bilaterais entre o Brasil e a Venezuela (1983-1998)}

Versão corrigida

Eliel Waldvogel Cardoso

Dissertação apresentada ao Programa de História Social do Departamento de História da Faculdade de Filosofia, Letras e Ciências Humanas da Universidade de São Paulo para obtenção do título de Mestre em História Social.

Orientadora: Prof ${ }^{\mathrm{a}}$. Dra ${ }^{\mathrm{a}}$. Maria Helena Rolim Capelato 


\section{AGRADECIMENTOS}

Registrar os agradecimentos é reconhecer um curioso paradoxo. Ao mesmo tempo em que o trabalho de pesquisa e redação é solitário, ele também é uma obra coletiva. Ao longo desses três anos, muitas pessoas me ajudaram no processo de seleção das fontes e de material bibliográfico. Mais do que isso, frequentemente me apoiaram de muitas outras maneiras, me fazendo reconhecer que esta dissertação só foi possível porque muitas pessoas acreditaram e se esforçaram por me ajudar.

Agradeço ao Departamento de História da Universidade de São Paulo por ter acolhido, através de seus professores, funcionários e alunos, o projeto que marcou o início deste trabalho.

Agradeço também à Coordenação de Aperfeiçoamento de Pessoal de Nível Superior (CAPES) pelo financiamento que recebi durante os meses finais da pesquisa e que foi de grande importância para que a dissertação pudesse tomar a sua forma final.

No Arquivo Histórico do Ministério das Relações Exteriores recebi grande ajuda do Oficial de Chancelaria Clovis Gomes de Aguiar Júnior, responsável pelo Arquivo durante a minha segunda visita. Clovis me atendeu com muita diligência, tanto presencialmente como à distância, e sou grato por isso. Meus agradecimentos a ele se estendem a todos os funcionários do Arquivo.

$\mathrm{Na}$ Hemeroteca do Senado Federal, a ajuda de Maria de Fátima da Silva Costa possibilitou que eu tivesse acesso às valiosas reportagens utilizadas na pesquisa. Ela também me atendeu à distância, complementando a pesquisa que fiz pessoalmente.

Também fui muito bem recebido na Embaixada da Venezuela em Brasília, onde o acervo da Biblioteca me proporcionou o contato com importante bibliografia.

Em Brasília, minha estadia durante a primeira visita foi garantida pelos amigos Helder Gonzales, Lucas Chalella das Neves e Bruno de Toledo de Almeida. Se fosse apenas pela estadia, minha gratidão já seria muito grande. Mas eles também contribuíram com ideias e, principalmente, com fraterna amizade. Para o Helder, registro ainda um segundo 
agradecimento, por me haver recebido outra vez, durante minha segunda visita à Capital Federal.

Também o Major Brigadeiro do Ar Álvaro Knupp dos Santos, sua esposa Maria Cristina e seus filhos Analice e Lucca me receberam muito amavelmente em sua casa, durante minha segunda estadia em Brasília. O apoio logístico e as dicas sobre a Base Aérea e a cidade foram muito úteis e são motivos para minha gratidão. Mais ainda devo agradecer pelos cuidados fraternos que me dispensaram em todos os momentos.

Ainda nessa ocasião pude me hospedar no hotel de trânsito da Base Aérea de Brasília, e sou grato pelos bons momentos que passei ali.

$\mathrm{Na}$ Venezuela, a equipe do Ateneo de Caracas contribuiu para que a minha estadia fosse agradável e produtiva.

Eu gostaria de agradecer aos funcionários do Ministério de Relações Exteriores da Venezuela, por me haverem franqueado amplo acesso à Biblioteca em que foram coletadas as informações do relatório anual do Ministério.

O Professor Alejandro Mendible Zurita, da Universidade Central da Venezuela, é um pioneiro dos estudos sobre as relações bilaterais. Para mim é um motivo de honra que ele tenha me recebido em sua sala na Universidade para mais de uma entrevista. O Professor acreditou no projeto e me deu preciosas dicas sobre a Biblioteca da Universidade, sobre os Arquivos do Ministério e sobre a rotina em Caracas. Mais ainda, ele me colocou em contato com acadêmicos e diplomatas que também contribuíram para aumentar o meu conhecimento. Foi um verdadeiro anfitrião e a sua cordialidade não pode ser esquecida.

Dentre as pessoas que me foram apresentadas pelo Professor Alejandro, quero agradecer especialmente à Professora Beatriz Demoly e à Irlanda Rincón Chalbaud, Diretora do Instituto Cultural Brasil Venezuela, órgão da Embaixada do Brasil em Caracas. Elas vivenciaram e continuam vivenciando dia a dia os esforços para construir uma relação cada vez mais sólida entre os dois países, e compartilharam com muita generosidade a sua experiência.

Os diplomatas venezuelanos José Bruzual e Jesús Mazzei Alfonso também foram generosos ao me receber para entrevistas, por indicação do Professor Alejandro. Eles 
compartilharam sua experiência como funcionários da Embaixada da Venezuela em Brasília e ajudaram a esclarecer valiosos detalhes sobre a cooperação nos anos 1990.

Quero agradecer também aos colegas e às Professoras do Laboratório de Estudos de História das Américas, do Departamento de História da USP. A convivência desses últimos três anos contribuiu imensamente para o amadurecimento deste trabalho, e foi importante para que eu aprendesse as imensas possibilidades desse campo que é a História.

Agradeço à Professora Maria Lígia Coelho Prado pelas aulas do curso de América Latina: Diálogos entre Política e Cultura, e pelas fecundas discussões que se estenderam pelo pós aula.

Agradeço ainda à Professora Gabriela Pellegrino, que muito contribuiu com os apontamentos feitos no exame de qualificação. Além disso, pude enriquecer meu conhecimento em disciplina ministrada por ela no Programa de Pós-Graduação e atuando como estagiário no curso de História da América Independente I para a Graduação. Assim se formou uma relação de amizade e de cooperação que valorizou es te trabalho.

Ao Professor Wagner Iglecias, quero agradecer pelos produtivos debates travados no curso de Pensamento Político Latino-Americano, ministrado no PROLAM-USP. Daqueles debates e de muitos outros que vieram depois, muita coisa contribuiu para a forma final de meu texto e para o artigo que apresentamos conjuntamente na CEPAL/ONU.

Por este trabalho e por todos os debates e leituras que compartilhamos, quero agradecer ainda ao meu bom amigo Ricardo Streich.

Muitos outros amigos contribuíram com debates e ideias para o amadurecimento desta pesquisa. Alguns deles foram colegas em disciplinas da pós-graduação. Tal é o caso de Alexsandro Silva, André Ponce, Ângela Meirelles, Brisa Cristina, Bruna Muriel, Caio Gomes, Carine Dalmás, Eça Pereira, Frederico Assis, Maria Antônia, e Rodolpho Gauthier. Outros amigos não foram colegas de disciplina, mas se interessaram pela pesquisa e debateram comigo. Agradeço ao Abimael Carvalho, Douglas Romão, Leandro Marques e Rodolfo Oliveira.

Agradeço aos meus pais, Eliel e Regina, por todo o apoio material, intelectual e emocional que me deram sempre, e mais intensamente durante o processo dessa pesquisa. 
Também quero agradecer aos meus sogros, Quirino e Olívia, que dedicaram à Catarina todo o tempo que as obrigações profissionais e acadêmicas não me possibilitaram.

Deixo também o meu muito obrigado à minha esposa, Viviane, que é também uma colega pesquisadora e que sempre aliou o suporte emocional a um estimulante convívio intelectual. A Viviane foi quem primeiramente acreditou no projeto de pesquisa e a que mais diretamente me apoiou em todos os desafios que a realização de um trabalho como este exige. O seu profundo conhecimento sobre a História foi sempre muito generosamente compartilhado comigo.

Por fim, quero destacar a importância que teve para mim a orientação da Prof ${ }^{a}$. Dr ${ }^{a}$. Maria Helena Rolim Capelato. A Professora orientou através de indicações de leituras, de ideias, da crítica atenta e minuciosa a todos os meus textos e muito além. Ele foi crucial para a elaboração do projeto com que obtive a bolsa de financiamento da CAPES. A Professora também supervisionou o meu estágio no curso que ministrou sobre História da América para os alunos da graduação, no segundo semestre de 2012. Naquela ocasião, pude aprender mais sobre a profícua relação entre pesquisa e docência, alargando os horizontes de minha formação. O seu apoio também foi fundamental para que eu pudesse expor, em conferência da CEPAL/ONU, alguns resultados preliminares da pesquisa. Por tantas coisas eu registro aqui o meu profundo agradecimento. 


\title{
RESUMO
}

O objetivo do trabalho é analisar o processo de aproximação diplomática empreendido pelos governos do Brasil e da Venezuela entre os anos de 1983 e 1998. Esse período foi marcado por forte crise econômica na América Latina, decorrente da elevação dos juros da dívida externa e da interrupção dos fluxos de financiamento. A situação de crise provocou reconfiguração de políticas econômicas e estruturas políticas nos dois países: os contextos similares permitiram o estreitamento de relações entre eles, mesmo a despeito das turbulências da crise. Procuraremos mostrar como se desenvolveram essas relações de natureza política e econômica, e suas relações com as estruturas de poder no sistema internacional.

\section{PALAVRAS-CHAVE}

História das Relações Internacionais; História Política; Integração Latino-Americana; Política Externa Brasileira; Política Externa Venezuelana.

\begin{abstract}
The object of the present dissertation is to analyze the process of diplomatic approximation undertaken by the governments of Brazil and Venezuela between the years of 1983 and 1998 . This period was marked by the profound economic crisis in Latin America, due to the rise of the interest rates of the external debt and the interruption of the finance flows. The critical situation led to the reconfiguration of economic politics and political structures in both countries: the similar contexts allowed the development of closer relations between them, in spite of the disturbances of the crisis. We seek to demonstrate how these relations of political and economic nature developed, and their relations with the power structures of the international system.
\end{abstract}

\section{KEYWORDS}

International Relations History; Political History; Latin American Integration; Brazilian Foreign Policy; Venezuelan Foreign Policy. 


\section{SUMÁRIO}

INTRODUÇÃO

1. APROXIMAÇÕES EM CONTEXTO DE CRISE (1983-1989) 27

1.1 AUGE E DECLÍNIO DO DESENVOLVIMENTISMO 32

1.2 COOPERAÇÃO EM INSTÂNCIAS MULTILATERAIS: CONTADORA E CARTAGENA $\quad 34$

1.3 CRISE ECONÔMICA E SEUS EFEITOS NA VENEZUELA E NO BRASIL 42

1.4 FORMAÇÃO DE UMA AGENDA BILATERAL A PARTIR DA COOPERAÇÃO

MULTILATERAL

1.5 INTENSIFICAÇÃO DA CRISE DA DÍVIDA EXTERNA E O FRACASSO DAS TENTATIVAS DE COOPERAÇÃO

2. APOIO MÚTUO À DEMOCRACIA E REFORMAS (1989-1994) 74

2.1 AS RELAÇÕES EM UM CONTEXTO DE REFORMAS ECONÔMICAS E A ELEIÇÃO DE CARLOS ANDRÉS PÉREZ

2.1.1 A eleição de Fernando Collor de Mello 85

2.2 AS RELAÇÕES BILATERAIS APÓS AS ELEIÇÕES VENEZUELANA E BRASILEIRA $\quad 88$

2.2.1 As trocas comerciais nesse novo contexto 90

2.2.2 Assuntos fronteiriços $\quad 97$

2.3 CRISE POLÍTICA 101

2.4 AS RELAÇÕES BILATERAIS DIANTE DO AGRAVAMENTO DA CRISE POLÍTICA

3. ADENSAMENTO DAS RELAÇÕES BILATERAIS A PARTIR DE NOVAS BASES (1994-1998)

3.1 PRIMEIROS RESULTADOS DO ENCONTRO DA GUZMANIA 118

3.1.1 O plano Real e suas consequências para as relações com a Venezuela 125

3.1.2 A diplomacia presidencial a partir da eleição de Fernando Henrique Cardoso $\quad 128$

3.1.3 Persistência da crise econômica na Venezuela 139

3.2 A SEGUNDA FASE DO NEOLIBERALISMO: NOVAS DIRETRIZES ECONÔMICAS

3.2.1 A Venezuela frente ao FMI

3.2.2 A visita de Caldera ao Brasil: novo marco nas aproximações

3.2.3 FHC e Rafael Caldera: protagonistas do encontro de 11 de abril de 1996

3.2.4 1998: eleições desviam atenção das relações bilaterais 158

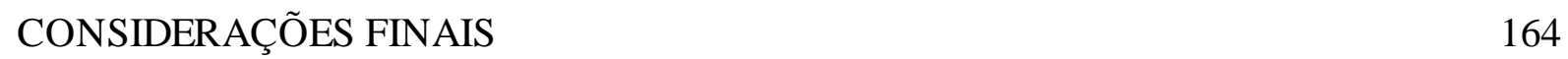

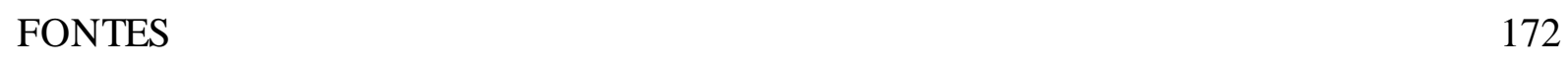

$\begin{array}{ll}\text { BIBLIOGRAFIA } & 174\end{array}$ 


\section{INTRODUÇÃO}

\section{ESTUDOS BRASILEIROS SOBRE A VENEZUELA E AS RELAÇÕES BILATERAIS}

Nos últimos anos, houve uma considerável produção acadêmica publicada sobre as relações internacionais do Brasil com diversos parceiros comerciais e políticos como Alemanha, EUA, Itália, Espanha, África do Sul, Argentina, e também Venezuela. Neste último caso, figuram a dissertação de mestrado de Mônica Vier Loss, que versou sobre $O s$ condicionantes econômicos e políticos no relacionamento Brasil-Venezuela de 1990-1998, ${ }^{1} \mathrm{e}$ o mais recente livro de Thiago Gehre Galvão, chamado Uma história de parceria: as relações entre Brasil e Venezuela (1810-2012). ${ }^{2} \mathrm{O}$ interesse de outros autores pelas relações bilaterais propriamente ditas tem sido superado pelo interesse relacionado à emergência da liderança do Presidente Hugo Chávez; muitos recorrem à história com o objetivo de compreender a deterioração das instituições do sistema político venezuelano a partir da segunda metade do século XX até a ascensão de Chávez ao poder. ${ }^{3}$ As análises de Rafael Villa sobre a política externa da Venezuela ${ }^{4}$ constituem exceções a esse padrão de interesse pela dinâmica política

\footnotetext{
${ }^{1}$ LOSS, Mônica V. Os condicionantes econômicos e políticos no relacionamento Brasil-Venezuela de 1990 1998. Dis sertação de Mestrado. Porto Alegre: UFRGS, 2007.

${ }^{2}$ GALVÃO, Thiago G. Uma história de parceria: as relações entre Brasil e Venezuela (1810-2012). Belo Horizonte: Fino Traço, 2012.

${ }^{3}$ ALMADA, Izaías. Venezuela: Povo e Forças Armadas. São Paulo: Caros Amigos, 2007.

BARROS, Pedro. Governo Chávez e desenvolvimento: a política econômica em processo. São Paulo: PUC, 2007. Dis sertação de Mestrado.

HITNER, Verena. Uma análise do malogro do modelo de desenvolvimento latino-americano dos anos 1990: os limites internos da Venezuela. São Paulo: USP, 2011. Dis sertação de Mestrado.

MARINGONI, Gilberto. A Venezuela que se inventa: poder, petróleo e intriga nos tempos de Chávez. São Paulo: Ed. Fundação Perseu Abramo, 2004. . A Revolução Venezuelana. São Paulo: UNESP, 2008.

MENDES, Flávio da Silva. Hugo Chávez em seu labirinto. O movimento bolivariano e a política na Venezu ela. São Paulo: Alameda/Fapesp, 2011.

NEVES, Rômulo F. Cultura política e elementos de análise da política venezuelana. Brasília, FUNA G, 2010. UCHOA, Pablo. Venezuela: a encruzilhada de Hugo Chávez. Rio de Jane iro: Globo, 2003.

4 VILLA, Rafael A. D. Carlos Andrés Pérez (1921-2010), de líder regional ao impeachment. In: Política Externa, Vol. 19, №. 4. São Paulo: Paz e Terra, Março/Abril/Maio 2011.

Rafael Caldera (1916-2009) e a democracia: memória política de um estadista latino-americano. In: Política Externa, Vol. 18, No. 4. São Paulo: Paze Terra, Março/Abril/Maio 2010. . Limites do ativismo venezuelano para A mérica do Sul. In: Política Externa, Vol. 16, No. 2. São Paulo: Paze Terra, Sete mbro/Outubro/Novembro 2007. Política externa na administração Hugo Chávez. In: Política Externa, vol. 13, № 1, São Paulo: Paz e Terra, Junho/Julho/Agosto 2004.
} 
interna sob Hugo Chávez, e por isso constituem referência de grande importância para nosso trabalho.

O estudo da política venezuelana das décadas que antecederam a eleição do presidente Chávez, em 1998, tem sido feito de maneira superficial. Por esse motivo, nosso trabalho tem por objetivo responder à demanda por um estudo da política dos tempos do "Punto Fijo" (1958-1998), e também identificar o lugar das relações bilaterais na estratégia de superação da crise. Mas, a compreensão dessas relações tal como se desenvolveram durante a crise dos modelos de desenvolvimento adotadas até então pelo Brasil e pela Venezuela nos levará mais além, fornecendo os subsídios para a compreensão do movimento de aproximação diplomática e comercial empreendido nos anos 1990, percebido em seu ineditismo pela maioria dos observadores e dos analistas.

Já existem alguns trabalhos voltados especificamente para as relações bilaterais entre o Brasil e a Venezuela. O mais antigo deles é o livro do venezuelano Julio Portillo, VenezuelaBrasil - Relaciones Diplomaticas 1842-1982, publicado em 1983, e que adotou um recorte cronológico bastante amplo. Em 1997, Alejandro Mendible Zurita, professor da Universidade Central da Venezuela, publicou Venezuela-Brasil - La historia de sus relaciones desde sus inicios hasta el umbral del Mercosur (1500-1997), ampliando ainda mais a cronologia. O primeiro trabalho brasileiro foi a publicação, em livro, dos textos e intervenções realizados em um seminário organizado pelo Itamaraty em 1995, e que envolveu autoridades e acadêmicos dos dois países. O diplomata brasileiro Samuel Pinheiro Guimarães foi o organizador da edição em livro, e também co-organizou outro trabalho, Venezuela: Visões brasileiras, publicado em 2001 também a partir de um seminário realizado sobre o tema, envolvendo dessa vez apenas autores do Brasil. Apenas mais recentemente, Mônica Vier Loss defendeu a dissertação de mestrado já citada, na qual se propôs a analisar um período mais restrito, entre os anos 1989 e 1998. Por fim, a publicação do livro acima citado de Thiago Gehre Galvão retomou a perspectiva de longa duração, e considerou que a década de 1980 significou para as relações bilaterais uma "primeira onda de adensamento". 5

\footnotetext{
${ }^{5}$ GA LVÃ O, op. cit., p. 136.

GUIMARÃ ES, Samuel P.(org.). Brasil e Venezuela: Esperanças e Determinação na Virada do Século, Brasília: FUNAG, 1995.

LOSS, op. cit.

; CARDIM, Carlos H.(orgs.). Venezuela: Visões Brasileiras, Brasília: FUNA G, 2001.
} 
Assim, o tema desta dissertação foi escolhido a partir do interesse que essas obras suscitaram em conhecer melhor a dinâmica dessas relações, recortando um período mais conciso do que fizeram os tratados de longa duração mas ao mesmo tempo mais amplo do que o enfoque de Mônica Loss, buscando analisar a inserção desse movimento de aproximação que caracterizou as relações no final do século XX em um contexto de crise econômica e política.

\section{APRESENTAÇÃO DO TEMA}

A crescente importância que a Venezuela ganhou no planejamento diplomático brasileiro ao longo da década de 1990 é consequência tanto de imposições conjunturais, como a baixa prioridade conferida pelos países desenvolvidos aos problemas econômicos da América Latina naquele momento; ${ }^{6}$ como do amadurecimento de uma maior disposição política para a cooperação no âmbito regional, na esteira dos entendimentos com a Argentina, na década anterior, ou mesmo do apoio brasileiro ao Grupo de Contadora, liderado pela Venezuela para dar solução política aos conflitos na América Central. É também um capítulo do projeto brasileiro de ampliação de seus contatos comerciais e políticos, segundo o entendimento de que ao Brasil está destinada uma posição de ator global, e não como apêndice de uma potência. ${ }^{7}$

A diversificação das relações internacionais do Brasil tem sido um objetivo de Estado, com pequenas revisões, desde a política de equidistância pragmática ${ }^{8}$ de Getúlio Vargas, no começo da II Guerra Mundial. O objetivo estratégico dessa política de diversificação, na maioria das vezes, tem sido a melhoria dos termos de barganha do Brasil frente à potência

MENDIBLE ZURITA, Alejandro. Venezuela-Brasil: La Historia de Sus Relaciones Desde Sus Inicios Hasta El Umbral del Mercosur (1500-1997), Caracas: FEPUVA, 1999.

PORTILLO, Ju lio. Venezuela-Brasil-Relaciones Diplomaticas 1842-1982. Caracas: Ed. Arte, 1983.

${ }^{6}$ SARDENBERG, Ronaldo M. As Relações Brasil-Europa. In: BAHIA, Luiz A. Questões críticas da situação internacional. Brasília: Ed. Un B, 1982.

SEIXAS CORREA, Luis. F. "A política externa de José Sarney.” In: ALBUQUERQUE, J. A. G. Sessenta anos de política externa brasileira (1930-1990). Crescimento, modernização e política externa. São Paulo: NupriUSP/Cultura Editores Associados, V. I, 1996, p. 361 - 385.

${ }^{7}$ BATISTA, P. N. “A política externa de Collor: modernização ou retrocesso?” Política externa, V. I, n. 4, 1993.

${ }^{8}$ MOURA, Gérson. Autonomia na dependência: a política externa brasileira de 1935 a 1942 . Rio de Janeiro: Nova Fronteira, 1980. 
he gemônica, o que no século XX quer dizer Estados Unidos. Em diversos momentos, porém, e a depender da importância estratégica de cada país, o incremento das relações bilaterais do Brasil tem servido aos propósitos de desenvolvimento nacional independentemente de sua repercussão nas relações entre o Brasil e os EUA. Parceiros estratégicos como a Argentina, a Alemanha, a Itália, a Espanha e Portugal apresentam historicamente fortes laços com o Brasil, o que já têm justificado a escrita de histórias das relações bilaterais. ${ }^{9}$ Tal produção historiográfica tem demonstrado de que maneira as conjunturas internas dos parceiros contribuem para mudanças de postura. A solução negociada das disputas em torno da cons trução da hidrelétrica de Itaipu, assim como a assinatura de um tratado de renúncia ao uso da energia nuclear com fins bélicos são identificados como momentos cruciais da distensão política com a Argentina. Mencionamos este exemplo para mostrar como as conjunturas internas, no caso a redemocratização quase simultânea dos dois países, ajudaram a modificar as relações entre ambos. ${ }^{10}$

O presente trabalho se diferencia das análises já realizadas sobre as relações bilaterais envolvendo o Brasil porque, no caso proposto para estudo, as relações não foram fruto, como as mencionadas anteriormente, de fluxos migratórios ou laços históricos de longa duração. Isto faz com que, no caso específico das relações com a Venezuela, seja engrandecida a importância do cálculo estratégico como motivador das políticas adotadas.

Através de pesquisa preliminar, constatamos também que a intensificação das relações bilaterais entre Brasil e Venezuela não é resultante de suposta densidade econômica ou populacional que pudesse encontrar-se nas áreas de fronteira, ou mesmo de intercâmbios culturais mais densos, até porque esses eram quase insignificantes ${ }^{11}$ quando os governos nos dois países decidiram por uma aproximação. Nossa pesquisa pretende contribuir para a historiografia que aborda as relações diplomáticas do Brasil com outro país, procurando mostrar como esse tipo de aproximação (Brasil-Venezuela) resulta de um complexo

\footnotetext{
9 SOUZA, Is mara I. Caminhos que se cruzam: relações históricas entre Brasil e Espanha. (1936-1960). FFLCH/USP, 2008. A tese de doutorado de Ismara Souza é um exemplo para o caso das relações do Brasil com a Espanha. Outros exemplos que envolvem os demais países mencionados estão na seção de Discussão Bibliográfica.

${ }^{10}$ GUERREIRO, Ramiro S. Lembranças de um empregado do Itamaraty. São Paulo: Siciliano, 1992.

${ }^{11}$ Existiram poucos mo mentos de interação cultural, apenas no sentido do Brasil para a Venezuela. Falamos especificamente no caso do acolhimento que alguns exilados brasileiros - figuras ilustres como Darcy Ribeiro e Celso Furtado - receberam naquele país durante os anos da ditadura, e do surto de popularidade que as novelas brasileiras experimentaram junto ao público venezuelano, nos anos 1980. MENDIBLE ZURITA, op. cit., p. 179189. Idem, "Darcy Ribeiro" Cadernos de História da Educação. V. 10, n. 1, Curitiba: UFP, jan./jun. 2011, p. 3350.
} 
planejamento estratégico, que visa fortalecer a atuação brasileira em âmbito internacional ao mesmo tempo em que serve a propósitos de desenvolvimento e integração econômica doméstica, notavelmente junto aos estados do Amazonas e Roraima, limítrofes com aquele país.

Para compreender as formas que a aproximação diplomática tomou, e o momento em que ela se tornou possível, além de politicamente desejável, é preciso voltar ao contexto dos anos finais da década de 1970 e começo da década de 1980. Esse momento está marcado economicamente pelo agravamento da situação financeira nos países da região. No âmbito externo, a elevação da taxa de juros nos EUA, como resposta unilateral à sua própria crise econômica, levou a uma elevação generalizada em todas as demais taxas flutuantes, incluindo aquelas que regulavam os pagamentos da dívida contraída pela maioria dos países latinoamericanos que, havendo contratado grande volume de empréstimos a taxas flutuantes de juros no período anterior, viram a dívida se multiplicar. No âmbito interno, o desajuste das contas nacionais se fazia sentir através da escalada das taxas de inflação.

Essas dificuldades econômicas, somadas à pressão política interna pela volta à democracia, obrigavam o governo brasileiro a abandonar temporariamente as pretensões de projeção de poder na região amazônica. As desconfianças dos vizinhos com relação às pretensões hegemônicas do Brasil foram sempre um obstáculo a mais para a diplomacia durante o regime militar. Os próprios venezuelanos somente se haviam disposto a assinar o "Tratado de Cooperação Amazônica", iniciativa brasileira para concertar entre os vizinhos as políticas para a região, depois de alguma relutância. ${ }^{12}$ No aspecto político, pesava contra o Brasil o histórico então recente de intervenções na política dos países vizinhos em nome do combate ao comunismo internacional, racionalizado segundo a doutrina das fronteiras ideológicas, que submetia a soberania estatal e o princípio de não-intervenção às necessidades de defesa da civilização cristã ocidental contra a ameaça oriental comunista. Essas desconfianças recíprocas, tão enraizadas na história da região, ${ }^{13}$ somente seriam superadas de

\footnotetext{
12 O tratado criava a Organização do Tratado de Cooperação Amazônica, e foi assinado por Bolívia, Brasil, Colômbia, Equador, Guiana, Peru, Suriname e Venezuela em julho de 1978. ARTEA GA S., Rosalia. A Organização do Tratado de Cooperação Amazônica (Otca): um desafio permanente. Diplomacia, Estratégia e Política. $\mathrm{N}^{\circ}$ 4. Abril/Junho, 2006, p. 86 - 100.

${ }^{13}$ CAPELATO, Maria Helena R. "O 'Gigante Brasileiro' na América Latina: ser ou não ser latino-americano". In: MOTA, Carlos G. (org.). Viagem Incompleta: A experiência brasileira. A Grande Transação. São Paulo: SENAC, 2000, p. 287-316.

PRADO, Maria Líg ia C. O Brasil e a distante América do Sul. Revista de História. N $^{\mathrm{O}} 145,2^{\circ}$ semestre de 2001. São Paulo: Hu manitas, USP, 2001.
} 
maneira gradual ao longo de toda a década, e para isso foram de crucial importância os entendimentos entre Brasil e Argentina, maiores potências da América do Sul. ${ }^{14}$

A crise da dívida não tardou em repercutir sobre as relações comerciais com o mundo desenvolvido de maneira geral. ${ }^{15}$ As maiores economias do planeta passavam, elas também, por uma reestruturação profunda. Este cenário possibilitou que, em meio à crise latinoamericana, o comércio do Brasil com esta região recebesse um inesperado estímulo, em razão do fechamento dos canais comerciais do norte. A crise econômica, contudo, se intensificava, e seria necessário recorrer à ajuda internacional para solucioná-la. Inspirados por aquelas reformas que aconteceram nos EUA e Reino Unido, economistas do Fundo Monetário Internacional (FMI), do Banco Mundial, do Tesouro estadunidense e de diversos países da América Latina realizaram um conjunto de trabalhos e reuniões em Washington D. C., já nos anos 1990. Participaram também consultores econômicos independentes e membros do Congresso dos EUA. ${ }^{16}$ As recomendações privilegiavam a abertura dos mercados e o recuo da participação estatal na economia.

O Consenso de Washington, como ficou conhecido este conjunto de recomendações, passou a ser aplicado de forma generalizada nos anos que se seguiram. Para a América Latina foi formulado o Plano Brady, que promoveu a renegociação da dívida externa da região, concedendo descontos sobre o montante e os juros da dívida, sob a condição de que as políticas do Consenso fossem implementadas. A aplicação das recomendações do Consenso, contudo, não se deu de maneira uniforme nos países da América Latina. O Chile, que já vinha liberalizando sua economia desde alguns anos antes sob a liderança de Pinochet, a Argentina e o México são frequentemente listados como os países que mais fielmente executaram as transformações sugeridas pelo Consenso. Venezuela e Brasil faziam parte do grupo de países mais reticentes, que buscaram manter certas características-chave do período

\footnotetext{
${ }^{14}$ OLIVEIRA, Henrique A. Política Externa Brasileira, São Paulo: Saraiva, 2005.

MELLO, Leonel I. A. Brasil e Argentina em Perspectiva. Revista de História. No 147. 2002. P. 211 - 234.

15 OLIVEIRA, op. cit.

ALMEIDA, Paulo R. de. Os primeiros anos do século XXI: O Brasil e as relações internacionais contemporâneas. São Paulo: Paze Terra, 2002.

CERVO, A mado L.; BUENO, Clodoaldo. História da Política Externa do Brasil. São Paulo: Ed. Ática, 1992.

16 BANDEIRA, Moniz. Conflito e integração na América do Sul - Brasil, Argentina e Estados Unidos: da Tríplice Aliança ao Mercosul (1870 - 2003). Rio de Janeiro: Revan, 2003.

SARAIVA, José F. S. (org.). História das Relações Internacionais Contemporâneas. São Paulo: Saraiva, 2007.
} 
desenvolvimentista enquanto reformavam também diversos setores da economia. ${ }^{17}$ No caso venezuelano, embora muitas empresas estatais estivessem sendo privatizadas durante o segundo mandato de Carlos Andrés Pérez, do partido Ação Democrática (AD), (1989-1993), a estatal petrolífera Petróleos de Venezuela, S. A. (PDVSA) constituiu exceção.

Mesmo reticente, a reforma econômica venezuelana se fez provocando muitas críticas em diversos setores da população. Já em fevereiro de 1989 uma manifestação popular contra o ajuste econômico do novo governo, provocada pelo aumento do preço das tarifas de transporte público, ${ }^{18}$ foi duramente reprimida, com saldo de centenas de mortos, segundo estimativas oficiais (fontes extraoficiais elevam os números a mais de mil pessoas). Some-se às instabilidades políticas a forte crise econômica em que se encontravam Brasil e Venezuela, enfrentando problemas similares no que diz respeito às altas taxas de inflação com baixo crescimento da atividade econômica e mau estado das contas públicas. Agravava a condição venezuelana a baixa dos preços do petróleo observada ao longo da década anterior. ${ }^{19}$

O Brasil, embora não escapasse, durante o século XX, da preponderância conferida por quase todos os países latino-americanos às relações com os EUA, possuía um portfólio mais diversificado em suas relações exteriores. ${ }^{20}$ Mesmo assim, concentrou-se em seus esforços de integração sul-americana principalmente com os países da bacia do Prata. Entretanto, incidentes com garimpeiros ilegais de origem brasileira, que atuavam em território venezuelano, forçaram uma aproximação entre os dois países já durante as gestões de Fernando Collor (1990-1992) e Carlos Andrés Pérez (1989-1993). ${ }^{21}$ Mas foi nos governos seguintes, de Itamar Franco (que substituiu Collor em 1992) e Rafael Caldera que os dois chefes de Estado, reunidos em março de 1994 na Venezuela, firmaram o "Protocolo da Guzmania", marco da aproximação entre os dois países.

\footnotetext{
${ }^{17}$ CERVO, Amado L. Relações Internacionais da América Latina - velhos e novos paradigmas. 2. Ed. São Paulo: Saraiva, 2007, p. 216.

18 AMORIM NETO, Octavio. "De João Goulart a Hugo Chávez: a política venezuelana à luz da experiência brasileira” In: GUIMARÃ ES, Samuel P.; CA RDIM, Carlos H.(orgs.). op. cit.

19 VIZENTINI, Paulo G. F.; CARRION, Raul K. M. A crise do capitalismo globalizado na virada do milênio. Porto Alegre: Editora da Universidade Federal do Rio Grande do Sul, 2000.

20 LAFER, Celso. Mudam-se os tempos: Diplomacia Brasileira - 2001/2002. Vols. I e II. Brasília: IPRI: FUNA G, 2002. SARAIVA, op. cit.

21 VIZENTINI, Paulo G. F. “A política externa da Venezuela frente à Globalização (1989 - 2001)” In: GUIMARÃES; CA RDIM. op. cit.
} 
No Comunicado Conjunto divulgado ao término da reunião, ficaram estabelecidos os objetivos de ampliação dos laços comerciais, criação de uma área de livre comércio sulamericana, articulação de projetos técnicos comuns à PDVSA e à Petrobrás e a proposta de desenvolvimento sustentável da região amazônica compartilhada entre os dois países, referindo-se especialmente aos setores de infraestrutura. Entre os dias seis e oito de setembro o Presidente Caldera esteve no Brasil onde participou das celebrações em torno do aniversário de Independência do país. Entrevistou-se com os dois principais candidatos à Presidência da República naquele ano, Luís Inácio Lula da Silva (PT) e Fernando Henrique Cardoso (PSDB), no que foi percebido pela imprensa venezuelana como demonstração do consenso brasileiro quanto ao estreitamento das relações.

Durante o período em que coincidiram as administrações de Caldera e FHC, a integração comercial entre Brasil e Venezuela aumentou consideravelmente, tornando-se o Brasil em um dos principais sócios comerciais do país vizinho. Ao mesmo tempo, os dois governos lideravam os esforços de aproximação entre a Comunidade Andina e o Mercosul. As propostas para conectar os dois blocos chegaram à ambiciosa meta de, no futuro, fundi-los. Paralelamente, o governo venezuelano estudava a possibilidade de estar filiado às duas organizações, fato que acabou não se concretizando.

Sobre as razões de tal evolução, o historiador Amado Luiz Cervo opina: "Durante as administrações dos presidentes Caldera, Chávez e Cardoso, de 1994 ao presente, o empenho pessoal dos chefes de Estado foi o motor principal da cooperação que engrandeceu nas esferas da ação política e econômica". ${ }^{22}$ Para a Venezuela, o mercado brasileiro oferecia oportunidades de negócios ainda inexploradas, a começar pela região Norte do país, onde está sediada a Zona Franca de Manaus, enclave industrial no seio da floresta amazônica.

Apesar de ter sido bem-sucedido na condução das relações com o Brasil, o mes mo não se pode dizer da administração econômica doméstica do segundo governo de Rafael Caldera, que vivenciou três anos de recessão econômica em cinco anos de gestão. Se nos primeiros anos de seu mandato o Presidente Caldera procurou desacelerar as reformas neoliberais em curso desde a gestão anterior, a crise financeira que atingiu o país na época o obrigou a buscar o auxílio financeiro do FMI em 1996, o que implicava nova adesão à receita econômica ortodoxa. Sua popularidade como governante entrou em declínio e com ela a confiança dos

\footnotetext{
${ }^{22}$ CERVO, A mado L., A Venezuela e seus Vizinhos, In: GUIMARÃ ES; CARDIM. op. cit.
} 
venezuelanos na capacidade de solução dos problemas econômicos do país dentro do quadro político herdado do Pacto de Punto Fijo. ${ }^{23}$ Nas eleições de dezembro de 1998 elegeu-se, com 56,2\% dos votos, o militar Hugo Chávez Frías (Movimento Quinta República - MVR, do qual foi fundador). A profundidade da mudança verificada na política venezuelana pode ser atestad a pelo seguinte trecho do artigo escrito pelo cientista político Octavio Amorim Neto:

Foi eleito para a presidência um militar golpista, Hugo Chávez, que, durante toda a campanha, atacou violentamente não apenas os partidos dominantes como toda a ordem política vigente, prometendo nada menos que a convocação de uma assembleia constituinte com poder para dissolver o Congresso. Ou seja, um outsider por excelência. ${ }^{24}$

A análise que estamos propondo se insere nessa conjuntura de crise econômica e grandes transformações políticas ocorridas na Venezuela, até hoje fruto de muita controvérsia.

\section{EXPOSIÇÃO DOS OBJETIVOS}

Tendo em vista a realidade do estreitamento das relações empreendido durante o período da crise entre os anos de 1983 e 1998, constitui objetivo desta pesquisa verificar de que maneira as relações bilaterais se inseriram em cálculos estratégicos de superação da crise, bem como a relação entre esses cálculos e as forças profundas que sobre eles incidiram. Partindo da constatação de que a integração entre os países latino-americanos estava, durante os primeiros anos da década de 1980, ideologicamente inserida dentro de um projeto de desenvolvimento de inspiração cepalina clássica, ${ }^{25}$ buscamos identificar o papel cambiante que as relações entre o Brasil e a Venezuela desempenharam dentro da racionalidade política nos dois países e a maneira como essa racionalidade foi afetada por eventos alheios ao

\footnotetext{
${ }^{23}$ Esse documento foi assinado em 1958, prevendo a cooperação entre os partidos políticos que se formaram com a restauração da democracia, após um período ditatorial sob o general Marcos Pérez Jiménez. Desde então a democracia venezuelana funcionou pela alternância no poder entre dois partidos: Acción Democrática (AD) e Comité de Organización Política Electoral Independiente (Copei). As crises econômicas a que nos referimos foram acompanhadas da crise política desse mesmo sistema de representação, culminando com o rechaço eleitoral aos partidos dominantes, em 1998.

${ }^{24}$ AMORIM NETO, op. cit, p. 94.

25 Desde os anos 1950, os trabalhos da CEPAL preconizavam a industrialização como caminho ao desenvolvimento da América Latina, mediante a as sociação entre países com economias de semelhante grau de industrialização, que gerasse economias de escala. BIELSCHOWSKY, Ricardo. (comp.) Sesenta años de la CEPAL: textos seleccionados del decenio 1998-2008. Buenos Aires: Sig lo Veintiuno Editores, 2010.
} 
controle dos tomadores de decisão, tal como a elevação das taxas de juros estadunidenses que desatou a crise da dívida externa.

De maneira subordinada e complementar a esse objetivo mais amplo, perfilam-se também outros objetivos. O primeiro deles ocupa o principal espaço nos capítulos centrais e consiste em construir a narrativa dos acontecimentos das relações entre os dois países segundo critérios de fidelidade às fontes e de relevância para o objetivo principal. Outro objetivo, para o qual nos voltamos na conclusão, é revisar, à luz dos acontecimentos narrados e dos critérios metodológicos apresentados nesta introdução, os conceitos de autonomia e de política externa para o desenvolvimento, propostos por Amado Cervo como eixos de suas análises sobre a história das relações internacionais do Brasil.

Por fim, o presente trabalho também tem por objetivo: confirmar a existência de um processo de aproximação intensificado a partir do encontro presidencial de 1994, tal como já exposto por outros autores, ${ }^{26}$ inserindo-o, porém, em um movimento contínuo que remonta às mudanças ocorridas na política externa brasileira frente aos vizinhos latino-americanos, desde a presidência de João Figueiredo (1979-1985).

\section{PER CURSO METODOLÓGICO}

Foi a partir da consolidação de uma nova história política que a história das relações internacionais se renovou, incorporando muitas de suas perspectivas teórico-metodológicas. ${ }^{27}$ Pierre Renouvin, e, mais tarde, seu discípulo, Jean-Baptiste Duroselle, procuraram desenvolver uma metodologia própria para a abordagem das relações internacionais, que foi sintetizada no livro Introduction à l'Histoire des Relations Internationales. Publicada pela primeira vez em 1964, a obra ainda permanece como uma das principais referências para a

\footnotetext{
${ }^{26}$ CERVO, Amado L. "A Venezuela e seus vizinhos". In: GUIMA RÂES; CARDIM. op. cit. GALVÃ O, op. cit. LOSS, op. cit.

${ }^{27}$ RÉMOND, René (org.). Por uma história política. Trad. Dora Rocha. 2 ed. Rio de Janeiro: Editora FGV, 2003.
} 
escrita da história das relações internacionais, juntamente com desenvolvimentos posteriores dessa metodologia, expostos no livro Todo Império Perecerá, de Duroselle. ${ }^{28}$

Os autores contribuíram para reformar o edifício da história diplomática removendo os escombros da destruição da velha história política, factual, monocausal, biográfica. Destacaram a relevância dos esforços feitos até então pela história diplo mática no sentido de se reconstituir as ações dos homens de estado, os processos decisórios e, até onde possível, as intenções dos policy-makers, ou seja, os "fazedores de política" externa consagrados pela ciência política anglo-saxã. Mas procuraram ampliar o escopo analítico do historiador estudioso das relações internacionais, destacando o papel das "forças profundas" que condicionavam o leque de escolhas disponíveis ao "tomador de decisões". Os autores afirmavam que:

\footnotetext{
“As condições geográficas, os movimentos demográficos, os interesses econômicos e financeiros, os traços da mentalidade coletiva, as grandes correntes sentimentais, estas são as forças profundas que têm formado a moldura das relações entre os grupos humanos e, em grande parte, determinado seu caráter. O homem de Estado, em suas decisões ou nos seus planos, não as pode negligenciar; ele sofre a sua influência, e ele é obrigado a constatar quais limites elas impõemà sua ação". 29
}

Renouvin e Duroselle buscaram integrar determinantes estrut urais e decisões humanas dentro de um mesmo quadro analítico, aproximando o objeto da história diplomática das inovações metodológicas representadas pelas novas correntes historiográficas do século XX. Pierre Milza atribuiu a Renouvin e Duroselle a introdução da política interna dos Estados no grupo dos principais determinantes do sistema internacional. Esta contribuição dos autores passou a ser incorporada em toda a Escola Francesa de história das relações internacionais e acabou se tornando seu traço mais marcante. A contribuição teórica daqueles autores, ao identificar os múltiplos elementos condicionantes das decisões em política externa, contribui para expor a fragilidade da dicotomia entre política interna e externa. Segundo Milza, foi a partir da publicação da Introduction, ou talvez um pouco antes em outras obras do próprio Renouvin, que o “dogma hobbesiano”, responsável pela ideia de separação entre as políticas interna e externa, começou a ser superado. ${ }^{30}$

\footnotetext{
28 DUROSELLE, Jean-Baptiste. Todo Império Perecerá: teoria das relações intemacionais. Brasília: UNB, 2000.

${ }^{29}$ RENOUVIN, Pierre; DUROSELLE, Jean-Baptiste. Introduction à l'histoire des relations internationales. $4^{\mathrm{a}}$ ed., Paris: Armand Colin Éditeur, 1991, p. 2.

${ }^{30}$ MILZA, Pierre. Política Interna e Política Externa. In RÉMOND, op. cit., p. 365-399.
} 
Renouvin e Duroselle descartaram a necessidade de o historiador das relações internacionais aderir, definitiva e antecipadamente, à determinação de razões ou econômicas ou políticas; eles reconhecem que ambos são condicionantes, mas que se alternam historicamente em sua preponderância. Cabe, assim, ao historiador, identificar momentos de predomínio das motivações políticas ou econômicas, e também a relação de mútua influência entre elas. Esta é a perspectiva que norteia nossa análise sobre as relações entre Brasil e Venezuela.

\subsection{DISCUSSÃO SOBRE A HISTÓRIA DAS RELAÇÕES INTERNACIONAIS DO BRASIL}

Durante muito tempo, a escrita da história diplomática no Brasil ficou a cargo dos próprios diplomatas, considerados desde os primórdios da nacionalidade como reserva intelectual da sociedade brasileira. Dentre os mais conhecidos autores que se dedicaram a essa vertente historiográfica, podemos citar Varnhagen, Joaquim Nabuco e, sobretudo, o Barão do Rio Branco, patrono da diplomacia brasileira.

Segundo Paulo Roberto de Almeida, ao longo do século XX, os historiadoresdiplomatas optaram pela análise de "períodos históricos mais limitados, espaços geográficos mais restritos ou temas políticos mais específicos, versando geralmente sobre problemas de fronteiras ou sobre questões diversas da diplomacia imperial", em comparação com os trabalhos de seus predecessores do século XIX. ${ }^{31}$

Em 1946 foram organizados cursos para a formação e aperfeiçoamento dos diplomatas brasileiros, no âmbito do Instituto Rio Branco, ligado à chancelaria brasileira. O contato que se fez possível entre historiadores, geó grafos, diplomatas e outros membros e professores das escolas militares foi decisivo para a consolidação de um cânone que marcou profundamente e, por muitos anos, a prática de história diplomática no Brasil. Esse cânone pode ser identificado com as histórias diplomáticas escritas por Hélio Vianna e Carlos Delgado de Carvalho. Estas duas obras, que sintetizaram o que até então se havia escrito sobre o tema, eram consideradas

\footnotetext{
${ }^{31}$ ALMEIDA, Paulo R. O estudo das relações internacionais do Brasil. São Paulo: Unimarco Editora, 1999 , p. 123.
} 
os guias mais confiáveis para a formação de diplomatas - e para informação do público interessado em geral.

José Flávio Sombra Saraiva destacou que, já em 1976, foi estabelecido na Universidade de Brasília o primeiro programa de pós-graduação em história das relações internacionais da América do Sul. Em torno daquela universidade se formou o que Saraiva chamou "grupo de Brasília", cujos componentes mais destacados são Amado Luiz Cervo, Paulo Roberto de Almeida, Clodoaldo Bueno, Paulo Fagundes Vizentini e o próprio José Flávio Saraiva. Nem todos esses autores são professores na Universidade de Brasília, mas a citação de seus nomes por Saraiva expressa a interpretação do autor de que há outros elementos que os unificam, constituindo assim uma verdadeira escola de história de relações internacionais no Brasil. $\mathrm{O}$ autor indica o que ele acredita serem esses elementos: a continuidade da tradição de Hélio Vianna e Delgado de Carvalho; a influência dos historiadores franceses e, em menor medida, britânicos, a "percepção de que os arquivos diplomáticos não são suficientes para uma boa pesquisa", devendo ser complementados por outras fontes, como as parlamentares, jornalísticas e entrevistas; e a "investigação sobre a inserção internacional do Brasil nos dois últimos séculos". 32

Sobre essa inserção internacional, o aspecto mais marcante do grupo de Brasília é a perspectiva de que a política externa brasileira, desde os anos 1930, estaria subordinada a objetivos de desenvolvimento do Brasil, perseguidos pelas elites políticas. Segundo Saraiva, a busca pelo desenvolvimento é o traço contínuo da política exterior brasileira desde então, com diferenças de interpretação entre grupos nacionalistas e grupos livre-cambistas. $\mathrm{O}$ autor acredita que a apreensão dessa regularidade é superior aos "velhos dogmas da teoria da dependência" porque os substitui pela "identificação das oportunidades concretas de desenvolvimento", substituindo a ênfase no estudo de conflitos pela ênfase nas "possibilidades e na prática da cooperação". ${ }^{33}$ Essa proposta metodológica do autor foi por nós compartilhada para a realização desta pesquisa sobre as relações entre o Brasil e a Venezuela, buscando observar em que medida a cooperação entre os dois países se influenciou por ideais nacionalistas ou livre-cambistas.

\footnotetext{
32 SARAIVA, José F. S. "História das Relações Internacionais: o objeto de estudo e a evolução do conhecimento". In: SA RAIVA, op. cit., p. 37.

33 Ibid. p. 38-39.
} 
Paulo Roberto de Almeida, embora citado por José Flávio Saraiva como integrante do grupo de Brasília, com cujos autores de fato participou em publicações conjuntas, é um autor diferenciado. Filiado à ideologia liberal, Almeida se diferencia dos autores citados acima quando se refere aos objetivos permanentes da política exterior brasileira, diluindo a autonomia em diversas manifestações, tais como a "afirmação e preservação da independência nacional, integridade territorial e manutenção da paz e da segurança militar, elevação do status do país, plena inserção internacional e afirmação renovada dos valores da nacionalidade", que se colocam ao lado do desenvolvimento econômico e social. ${ }^{34}$ Em livro sobre "O Estudo das Relações Internacionais do Brasil", o autor oferece um quadro bem mais amplo dos principais autores e temas que versaram sobre o assunto, reconhecendo, porém, a centralidade do conceito de autonomia, abordado por diversos autores. Lamentavelmente, a popularidade do conceito nunca suscitou maiores preocupações por delimitar precisamente a sua aplicação.

É notável que a palavra autonomia seja tão utilizada, tendo em vista a contraposição semântica que se estabelece em relação a outras abordagens, agrupadas sob o rótulo de "teorias da dependência". Segundo Almeida, os estudiosos da autonomia buscaram elaborar receitas para a inserção mais autônoma possível para o Brasil em um sistema internacional oligárquico, ainda que, para isso, tenham negligenciado o desenvolvimento de perspectivas teóricas mais ambiciosas. ${ }^{35}$

Dentre os autores do grupo de Brasília, Paulo Roberto de Almeida identifica particularmente Amado Cervo como um autor que enfatiza a questão da autonomia do Brasil. A forma como a obra de Cervo se relaciona com a autonomia, na interpretação de Almeida, que compartilhamos, é dicotômica, classificando a política externa brasileira em alguns momentos como "liberal-conservadora", contrária à busca por autonomia e a defesa do interesse nacional, e em outros momentos como "nacional-desenvolvimentista", comprometida com a autonomia, o interesse nacional e o desenvolvimento. ${ }^{36}$

A publicação de "História da Política Exterior do Brasil" (1992), escrita por Amado Cervo e Clodoaldo Bueno consolidou a atualização metodológica das práticas de pesquisa, com marcada influencia da academia francesa e das contribuições de Renouvin e Duroselle.

\footnotetext{
${ }^{34}$ ALMEIDA, Paulo R. op. cit, p. 16.

${ }^{35}$ Ibid. p. 138-140.

${ }^{36}$ Ibid. p. 141-143.
} 
Os autores incorporaram os ensinamentos dos franceses reconhecendo que: "o historiador transita, constantemente, das condições objetivas, estabelecidas pelas forças profundas, aos fins da política, passando pela análise das decisões de Estado". 37

Sobre esse livro, que se tornou a maior referência no campo da história das relações internacionais do Brasil, Paulo Roberto de Almeida escreveu uma resenha bastante elogiosa, em que saudou especialmente:

A recusa da chamada "teoria da dependência", que contaminou bom número de trabalhos acadêmicos nas últimas duas décadas. Realmente, a alegada conivência das elites com um projeto de dominação externa não encontra fundamentos empíricos, a não ser ao nível do anedótico. ${ }^{38}$

$\mathrm{Na}$ introdução para a quarta edição desse livro, Amado Cervo e Clodoaldo Bueno afirmam sua missão de "consolidar o conhecimento elaborado sobre as relações internacionais do Brasil e revestir a síntese resultante desse esforço com uma nova interpretação histórica". 39 Em outro trecho, os autores esclarecem que tal interpretação:

Corresponde precisamente ao caráter supletivo do setor externo, em um país como o Brasil, em função dos condicionamentos objetivos e da vontade política, para promover ou retardar o processo de desenvolvimento econômico e social, que se deu por inserção na expansão e nas mudanças do sistema capitalista. Essa hipótese orientou a procura, através do tempo, dos fatores repressivos e estimulativos da dinâmica social, sem respeito a postulados mecanicistas ou a teorias explicativas isoladas. ${ }^{40}$

A metodologia do presente trabalho consiste na aplicação do conceito de Pierre Renouvin de "forças profundas" à hipótese de que as relações entre o Brasil e a Venezuela no período em destaque podem ser entendidas em função do caráter supletivo da política exterior em relação ao objetivo do desenvolvimento, conforme a interpretação acima mencionada a respeito da história da política exterior brasileira. Buscamos estender essa interpretação também para a política exterior da Venezuela no mesmo período e, mais especificamente, para suas relações com o Brasil.

\footnotetext{
${ }^{37}$ CERVO; BUENO. op. cit, p. 10. José Flávio So mbra Saraiva também reconheceu explicitamente a influência preponderante de Pierre Renouvin e Jean-Baptiste Duroselle sobre a nova história das relações internacionais no Brasil. SARAIVA, op. cit.

38 ALMEIDA, Paulo R. “A nova his tória dip lo mática”. In: Revista Política Externa. Vol. 1, n 2, Setembro 1992 , p. 204.

${ }^{39}$ CERVO, A mado L.; BUENO, Clodoaldo. História da Política Exterior do Brasil. 4. Ed. Brasília: UnB, 2011 , p. 13.

${ }^{40}$ Ibid, p. 16.
} 


\section{ORGANIZAÇÃO DOS CAPÍTULOS}

O primeiro capítulo se refere ao momento de aproximação entre representantes do Brasil e da Venezuela, num contexto de crise que deixou evidente a necessidade de cooperação multilateral entre os países da América Latina. O impacto da crise da dívida externa, que significou a falência dos modelos de desenvolvimento adotados nas décadas anteriores na maioria dos países da região, provocou mudanças importantes na prática diplomática dos países da região, incluindo o Brasil e a Venezuela.

Nesse momento, os formuladores da política externa do Brasil, que durante os anos 1970 se mantiveram distantes das posições terceiro-mundistas, acabaram se conscientizando de que o "Gigante Brasileiro" compartilhava da fragilidade dos demais países latinoamericanos perante os atores mais fortes do capitalismo internacional, fossem eles os Estados mais desenvolvidos ou os bancos privados. Tal conscientização se materializou na disposição de cooperação multilateral com os países vizinhos: a Venezuela logo emergiu como um dos parceiros mais receptivos à aproximação com o Brasil.

Procuraremos mostrar, a partir da exposição do contexto internacional, que a Venezuela foi, dentre os países latino-americanos e no período anterior à crise, um dos mais ativos promotores das posições terceiro-mundistas que reivindicavam a construção de uma ordem internacional mais equitativa.

No segundo capítulo, nos propusemos a analisar o momento no qual os dois países aderiram ao modelo neoliberal, formulado através do Consenso de Washington, com o objetivo de solucionar o problema da crise econômica. Destacamos semelhanças entre os dois países no que se refere tanto aos resultados da crise, como em relação aos programas políticos e econômicos adotados para solucionar os problemas.

Constatamos, a partir das análises sobre o momento da crise que ele foi particularmente fértil para a mobilização dos atores com vistas à interferência nas estruturas econômicas e políticas. A reflexão sobre o significado político da eleição de Carlos Andrés Pérez, na Venezuela, e de Fernando Collor de Mello, no Brasil nos ajuda a compreender as mudanças que ocorreram no período. Os traços de personalidade impulsiva que caracterizou a "performance nacionalista" dos dois presidentes, contribuíram para ocultar a origem externa 
das políticas que estavam sendo adotadas inspiradas no Consenso de Washington. A análise desse processo tem como objetivo mostrar o entrelaçamento entre as estruturas econômicas e políticas vigentes, a atuação dos atores e as tentativas de transformações estruturais empreendidas nos dois países, bem como a incidência dessas transformações sobre as relações bilaterais.

Nas relações entre o Brasil e a Venezuela, em cujo território fronteiriço está situada parte da floresta amazônica, os temas do combate ao narcotráfico e da proteção ambiental ganharam materialidade na cooperação pelo patrulhamento fronteiriço. Esse aggiornamento do manejo dos assuntos fronteiriços de acordo com os temas emergentes conviveu com formas mais antigas de se interpretar os incidentes da fronteira. O histórico de desconfiança geopolítica, particularmente presente na cobertura da imprensa venezuelana sobre os assuntos de fronteira, conviveu com os esforços governamentais para apresentar soluções de cooperação "técnicas" e de baixo perfil hierárquico, evitando a contaminação da agenda bilateral.

O terceiro capítulo procura mostrar a alteração das prioridades no que se refere às relações bilaterais na agenda diplomática do Brasil e da Venezuela. Contrariamente ao que se chegou a temer, o impedimento dos presidentes Carlos Andrés Pérez e Fernando Collor de Mello não acarretou a interrupção do processo democrático nos dois países. A estabilização relativa da economia brasileira, empreendida pelos presidentes Itamar Franco e Fernando Henrique Cardoso, possibilitou uma mudança no perfil diplomático do país através da qual a aproximação com a Venezuela tornou-se um dos objetivos prioritários, tendo como perspectiva a formação de uma comunidade política e econômica ampliada na América do Sul. Com relação à Venezuela, a incorporação do México ao Acordo de Livre Comércio da América do Norte (NAFTA) frustrou um projeto da diplomacia venezuelana de se aproximar dos mexicanos, mas favoreceu a aproximação com o Brasil.

\section{A ESCOLHA DAS FONTES}

Para escrever a história dessa aproximação, recorremos a uma série documental abrangente sobre o período, combinando a correspondência trocada entre a embaixada 
brasileira em Caracas e o Ministério das Relações Exteriores, os relatórios anuais do Minis tério das Relações Exteriores venezuelano, artigos publicados em revistas especializadas em ambos os países (Revista de Política Internacional na Venezuela e Revista Brasileira de Política Internacional) com periódicos da grande imprensa brasileira para analisar como noticiaram os eventos políticos venezuelanos. Quanto aos periódicos especializados, a sua cobertura cronológica é mais tardia, pois a Revista de Política Internacional foi publicada apenas entre 1986 e 2000, e a Revista Brasileira de Política Internacional publicada durante todo o período sob análise neste trabalho (1983-1998).

A documentação produzida pelos ministérios de relações exteriores e suas representações no estrangeiro também compõe a lista de fontes para análise. No entanto, cabe esclarecer que não tivemos acesso à totalidade desse material, uma vez que parte dele não foi disponibilizado para consulta, inclusive as correspondências trocadas entre embaixadores e as chancelarias. $^{41}$

O Ministério das Relações Exteriores da Venezuela publica anualmente um relatório, chamado Libro Amarillo, em que são compiladas diversas atividades administrativas, juntamente com o texto dos tratados e acordos assinados pelas autoridades venezuelanas no período, além dos discursos proferidos em visitas bilaterais e fóruns multilaterais. Consultamos esses relatórios que estão disponíveis tanto na embaixada da Venezuela em Brasília como na sede do Ministério das Relações Exteriores, em Caracas.

Por se tratar de uma pesquisa histórica do tempo presente, foi importante recorrer a entrevistas. Cabe fazer referência às pessoas que colaboraram conosco neste sentido: a professora Beatriz Demoly, brasileira, professora do Instituto Cultural Brasil-Venezuela desde 1998; os diplomatas venezuelanos Jesús Mazzei Alfonzo, adido político da embaixada

\footnotetext{
41 A legislação venezuelana estabelece que todas as correspondências oficiais permaneçam por trinta anos em segredo. A legislação brasileira diferenciava os documentos em cinco categorias: ostensiva, reservada, confidencial, secreta e ultrassecreta. A correspondência reservada requeria um prazo mínimo de cinco anos para ser acessada, mas esses cinco anos eram prorrogáveis, em regime automático, por mais cinco, totalizando dez anos de isolamento. Os documentos classificados como confidenciais permaneciam guard ados por dez anos, prorrogáveis por mais dez, enquanto os documentos secretos e os documentos ultrassecretos permaneciam inacessíveis por vinte e trinta anos, respectivamente, e esses prazos também eram prorrogáveis por igual período. Contudo a Lei de Acesso à Informação ( $n^{\circ}$ 12.527, de 18 de novembro de 2011) exigiu a reavaliação das informações classificadas no grau ultrassecreto e secreto, em prazo máximo de dois anos contados a partir da Lei $\mathrm{n}^{\circ}$ 12.527. Fizemos, por isso, segunda viagem de coleta de fontes a Brasília, onde os documentos secretos produzidos entre 1983 e 1988 já estavam reclassificados, e a maioria deles estava disponível para consulta. Por isso, foram incorporados a esta pesquisa. Os documentos secretos produzidos pela embaixada brasileira em Caracas entre os anos de 1989 e 1998 se encontram, no momento, em processo de reavaliação.
} 
venezuelana entre 1996 e 2000 e José Bruzual, seu sucessor a partir de 2000. Especialmente importantes para nosso trabalho foram as entrevistas concedidas pelo professor vene zuelano Alejandro Mendible Zurita, especialista em história das relações bilaterais, da Universidade Central da Venezuela. 
Para melhor compreender o contexto no qual se alteraram e se intensificaram as relações entre o Brasil e a Venezuela, consideramos necessário fazer referência aos modelos de desenvolvimento que foram adotados nesses países a partir do pós-guerra. Esta referência é importante porque os sucessos e os fracassos desses modelos orientaram, em grande parte, as opções políticas adotadas nos anos de crise. A partir delas foi atribuído papel importante à parceria estratégica entre os dois países.

As semelhanças e diferenças apresentadas entre os modelos de desenvolvimento venezuelano e brasileiro na segunda metade do século merecem destaque. No campo econômico predominou, a partir dos anos 1930, a orientação keynesiana que atribuía ao Estado uma função promotora do desenvolvimento, através de investimentos em infraestrutura, da operação de empresas estatais em setores considerados estratégicos, e de um sistema de seguridade social capaz de distribuir parte dos benefícios do crescimento econômico. Tal orientação seguia o paradigma dominante no mundo capitalista desse período e estava enraizada na experiência de superação da crise econômica de 1929 Também o desempenho das economias do bloco socialista decorrente da rápida industrialização, contribuía para reforçar a importância do papel do Estado no planejamento e operação de atividades econômicas. $\mathrm{Na}$ interpretação de Amado Cervo, esse modelo de desenvolvimento econômico se conjugou com uma linha de atuação diplomática que buscou complementar os esforços de desenvolvimento perdurando, com poucas interrupções, até o seu abandono por decorrência da crise da dívida externa, já no final dos anos $1980 .^{42}$

Brasil e Venezuela, durante a maior parte desse período, que corresponde às décadas de 1930-80, estruturaram modelos econômicos a partir dessa concepção de Estado que atribuía a ele funções de protagonista na promoção do desenvolvimento; tal política econômica ficou conhecida na região como desenvolvimentista.

No entanto, cabe lembrar que o financiamento para o desenvolvimento desses países provinha, majoritariamente, do sistema financeiro internacional. A partir do final dos anos 1960 e começo dos anos 1970, a economia mundial passou por um processo de expansão das atividades dos bancos privados no plano interacional. Tais bancos receberam, a partir de então, volumosos aportes dos países exportadores de petróleo que através da Organização dos

\footnotetext{
42 CERVO, A mado L. Relações Internacionais na América Latina: velhos e novos paradigmas. 2. Ed. São Paulo: Saraiva, 2007, p. 219.
} 
Países Exportadores de Petróleo (OPEP) conseguiram elevar os preços pagos por esse produto. A liquidez desses bancos internacionais foi repassada, em grande parte, para os países do chamado Terceiro Mundo, que emprestaram o dinheiro a taxas de juros relativamente baixas, mas condicionadas à flutuação da taxa de juros praticada nos Estados Unidos e no Reino Unido.

O desenvolvimento econômico promovido pelos governos do Brasil e da Venezuela foi financiado, na década de 1970, pelos recursos desses bancos. As consequências desses financiamentos para a autonomia daqueles países serão abordadas posteriormente.

A principal diferença entre o modelo brasileiro e o modelo venezuelano era que, neste último caso, as exportações de petróleo, matéria prima altamente valorizada nas economias industrializadas constituíam, praticamente, a única fonte de receita para sustentação das funções do Estado e garantir o pagamento dos empréstimos. Também as exportações de ferro contribuíam com pequeno porcentual das receitas governamentais. ${ }^{43}$

O nível da industrialização na economia venezuelana era baixo, à exceção da indústria ligada ao setor extrativista. A Venezuela se valia das receitas das exportações de petróleo e ferro para importar bens de capital e principalmente de consumo. ${ }^{44} \mathrm{~A}$ economia brasileira era mais diversificada. Não sendo um produtor de petróleo em grande escala, o Brasil importava o produto, mas em contrapartida contava com um parque industrial desenvolvido o bastante para prover boa parte do consumo do mercado interno, além de gerar receitas de exportações destinadas, especialmente, para os mercados dos países vizinhos. As commodities, concentradas em produtos agrícolas e minerais, também contribuíam muito para o aumento das receitas.

A partir dos anos 1970, o contexto latino-americano foi se modificando. No caso do Brasil, o regime civil-militar que se instaurou no país a partir do golpe de 1964, também passou por modificações e, na década de 1970 tornou-se evidente a pretensão dos representantes do regime, no plano geopolítico, de alçar o país à condição de potência hegemônica na América do Sul. Os presidentes militares, orientados por essas pretensões de hegemonia, tinham como objetivo a constituição de uma ampla rede de cooperação, em

\footnotetext{
${ }^{43}$ O Globo, 28/11/1978.

44 Jornal de Brasília, 12/08/1978.

FURTADO, Celso. Ensaios sobre a Venezuela: subdesenvolvimento com abundância de divisas. Rio de janeiro: Contraponto: Centro Internacional Celso Furtado, 2008.
} 
termos de segurança política e desenvolvimento econômico, que abrangesse a América do Sul, o Atlântico Sul e o Pacífico Sul-americano. Havia requisitos a preencher na construção desse espaço sob a liderança brasileira: além de neutralizar as pretensões de qualquer rival que pudesse fazer frente ao Brasil, tanto na América do Sul, como em outras regiões, cabia ao governo brasileiro aprofundar o controle territorial do país, integrando as diversas regiões e fortalecendo a proteção das fronteiras. ${ }^{45}$ Somava-se a esses desafios o controle da política interna que já caminhava no sentido de uma abertura política, de forma "lenta, gradual e segura". Já nessa década, as restrições aos direitos civis e políticos, as recorrentes formas de violência e tortura praticadas por agentes do Estado, passaram a ser contentadas, tanto no exterior, como internamente. O regime autoritário perdia legitimidade frente à opinião pública doméstica e internacional. Nesse contexto, as relações com a Venezuela eram problemáticas do ponto de vista político: o país vivia sob um regime liberal e os governos, através de seu corpo diplomático, assumiam o papel de promotores da democracia no continente. Havia, portanto, forte discrepância política entre os dois países.

Os objetivos geopolíticos dos governos militares brasileiros não foram jamais explicitados pela diplomacia que, através de um discurso pacifista, procurava legitimar as pretensões dos governantes de exercer domínio militar na região, sempre em nome da ameaça comunista. O discurso pacifista dos diplomatas servia também para encobrir a fragilidade do poderio militar que contava com escassos recursos e, portanto, contrastava com o poder dos militares na política. Além disso, o distanciamento do Brasil em relação aos demais países da América Latina e as desconfianças mútuas, historicamente nutridas entre o Brasil e seus vizinhos, persistiam e bloqueavam o caminho, não só da aproximação mas, sobretudo, da liderança na região, pretendida pelos governantes militares. Em suma, apesar das pretensões de transformar o Brasil numa grande potência, sempre invocando a extensão territorial e a abundância dos recursos naturais, o país continuava apresentando baixos índices de desenvolvimento, visíveis através do quadro de desigualdade social e precariedade dos serviços públicos. Apesar disso, no final da década de 1970, o bom desempenho de alguns

\footnotetext{
45 CA VA GNARI FILHO, Geraldo L. "Estratégia e Defesa (1960-1990)". In: ALBUQUERQUE, José A. G. (org.). Sessenta anos de política externa brasileira (1930-1990): Prioridades, atores e políticas. São Paulo: Annablume / NUPRI/USP, 2000. V. 4, P. 119-121.
} 
setores da economia, foi usado como instrumento de propaganda: os dados eram apresentados como sinal de um futuro radioso já nos primórdios do século XXI. ${ }^{46}$

A experiência política venezuelana no período da guerra fria foi bastante distinta da brasileira. Em 1958 foi deposta a ditadura militar chefiada por Marcos Pérez Jiménez desde 1948, inaugurando um período de continuidade democrática que não foi interrompida em nome da luta contra o comunismo, como aconteceu nos países do Cone Sul. Entre 1958 e 1994, ou seja, durante 36 anos, a política se caracterizou pela alternância entre dois partidos no poder - Ação Democrática (AD, ligado aos sindicatos, membro da Internacional Socialista e de tendência socialdemocrata) e Comitê Político Eleitoral Independente (Copei, de orientação democrata cristã). A bibliografia sobre a política venezuelana do período cunhou a expressão "democracia de Punto Fijo" para se referir a esse arranjo político que funcionou até os anos finais do século XX. Os dois partidos dominavam a vida política nacional, mas a alternância no poder era desigual: a Ação Democrática venceu mais eleições (cinco) do que o Copei (duas), e estava profundamente conectada com a maior central sindical do país, a Confederação dos Trabalhadores da Venezuela (CTV). O funcionamento desse sistema político foi bem definido pelo autor Carlos Romero nos seguintes termos:

\begin{abstract}
Pudiera definirse como el tiempo en el cual las elites políticas nacionales diseñaron un modelo de negociación entre ellas que se conceptualizó como el modelo populista de conciliación de elites y conocido popularmente como el "Pacto de Punto Fijo". Este modelo fue desarrollando una ingeniería política, una politeia basada en un proyecto nacional con rasgos democráticos representativos y una fuerte intervención del Estado en la economía y en la vida social, en el marco de unas reglas de juego explícitas garantizadas por la Constitución Nacional del año 1961 y con el respaldo de las Fuerzas Armadas y de la comunidad democrática internacional al experimento democrático. ${ }^{47}$
\end{abstract}

A política externa venezuelana foi muito condicionada pela "excepcionalidade democrática" em um continente de profusas intervenções dos militares na política. Desde a eleição do Presidente, Rómulo Betancourt, após o término da ditadura, consagrou-se na Venezuela a chamada "doutrina Betancourt", que preconizava a missão de defesa da democracia contra as ameaças comunistas e militaristas. ${ }^{48}$ Veremos ao longo deste trabalho

\footnotetext{
${ }^{46}$ Ibidem, p. 123-125.

47 ROMERO, Carlos. "La crisis política en Venezuela", In: ARAÚJO, Helo isa V. de (org.). Os Países da Comunidade Andina. Brasília: Fundação Alexandre de Gusmão: Instituto de Pesquisa de Relações Internacionais, 2004, p. 15.

48 Amado Cervo considera a diplomacia venezuelana do período imediatamente após a ditadura permeada por certo desejo isolacionista, alimentando desconfianças frente às doutrinas terceiro-mundistas, e também por qualquer outro projeto de integração sub-regional, como a própria Associação Latino-A mericana de Livre
} 
que a diplomacia venezuelana nem sempre foi fiel a essa doutrina, e nem sempre conseguiu manter-se equidistante dos blocos capitalista e comunista.

Em 1964, a Venezuela rompeu relações diplomáticas com o Brasil em razão do golpe militar. Tal situação não se sustentou por muito tempo e, já em 1966, o governo venezuelano anunciou a normalização das relações. ${ }^{49}$

Ao longo dos anos seguintes, o proselitismo democrático foi se fragilizando à medida que se tornavam evidentes os interesses da política externa venezuelana na região. A diplomacia venezuelana tinha como meta exercer influência econômica e política nas seguintes direções: ao sul da região andina, que compreendia o Peru, o Equador e a Colômbia; a leste, na região amazônica, que compreendia Brasil, a Guiana e o Suriname e, ao norte, que compreendia a bacia caribenha, incluindo os países da América Central. ${ }^{50}$ Tal projeto, que implicava maior proximidade com os países vizinhos, fragilizava o proselitismo democrático. Para exercer influência, convinha reduzir áreas de atrito, em um contexto onde proliferavam ditaduras militares.

Historicamente, a diplomacia venezuelana era integracionista, rejeitando posições de isolamento. Simón Alberto Consalvi, ministro de Relações Exteriores da Venezuela entre 1977 e 1979, escreveu, posteriormente, que a luta pela independência do país conduzida por Simón Bolívar, comandante dos exércitos que partiram dessa região com o propósito de libertar a América hispânica, deixou fortes marcas na política externa do país. ${ }^{51}$

Comércio (ALALC) e mes mo o GATT (General Agreement on Tariffs and Trade - Acordo Geral sobre Tarifas e Comércio). CERVO. op. cit.

${ }^{49}$ MENDIBLE ZURITA. op. cit., p. 175.

${ }^{50}$ MICHELE Y, Giovanna de. "Venezuela-Brasil no Cenário Internacional” In: GUIMARÃES, op. cit., p.51. SERBIN, Andrés, "Venezuela ante el Caribe de habla inglesa: categorizaciones y contrastes cognitivos". In: Revista de Política Internacional, Ano 1987 - Nro. 6 - Abril-Junio, p. 23-24.

${ }^{51}$ CONSALVI, Simón Alberto. Una Política Exterior Democratica en Tiempos de Crisis, Caracas: Editorial Pomaire, 1988, p. 26-27. Quanto à importância da versão heróica da história da independência venezuelana para a formação dos conceitos de política externa do país concordou ainda ROMERO, Aníbal. "La Situación Estratégica de Venezuela" In: Revista de Política Internacional. Ano 1986 - Nro. 1 - Enero-Marzo, p. 10-13. 


\subsection{AUGE E DECLÍNIO DO DESENVOLVIMENTISMO}

A década de 1970 trouxe mudanças no funcionamento do sistema econômico internacional. Já em 1973, a elevação dos preços do petróleo, coordenada entre os países membros da OPEP, reconfigurou o fluxo de recursos internacionais. Para os países produtores, a subida dos preços (que foi sucedida por uma nova elevação, em 1979) significou a súbita multiplicação da entrada de dólares. Para todos os demais países, a nova situação pressionou o equilíbrio das finanças, ainda mais porque o petróleo era um insumo energético imprescindível. O Brasil foi particularmente afetado em um momento de crescimento econômico através da industrialização.

Na Venezuela, a primeira presidência de Carlos Andrés Pérez (AD, 1974-1979) caracterizou-se por um forte ativismo diplomático. Foi uma época de prosperidade para o país, em razão da elevação dos preços internacionais do petróleo, que correspondeu também ao auge da democracia de Punto Fijo que se legitimava graças à redistribuição dos dividendos da exportação. Durante esse governo, foi celebrado o Acordo de San José, através do qual Venezuela e México garantiam a venda de petróleo aos pequenos países do Caribe em condições especiais de financiamento. O Acordo garantia influência na região "beneficiada". 52 Também nesse período, houve um esforço de aproximação entre a Venezuela e o Brasil, evidenciadas nas declarações positivas do presidente venezuelano à imprensa brasileira, por ocasião da primeira visita oficial de um presidente ao país. Como resultado desse encontro, concretizou-se a adesão da Venezuela ao Pacto Amazônico que, por iniciativa do Brasil, congregava os interesses e iniciativas dos países sul-americanos nesse território. ${ }^{53}$

Nos tempos da alta renda do petróleo, as empresas estatais - Companhia Petróleos da Venezuela, Edelca e Cadafe (geração de energia elétrica), a grande Siderúrgica do Orinoco (Sidor) e a Companhia Venezuelana de Fomento - tinham o compromisso de promover investimentos na infraestrutura do país. A outra parte da renda, oriunda das vendas do petróleo, deveria ser investida no exterior pelo Fundo de Investimentos da Venezuela, para

\footnotetext{
52 CARDOZO DA SILVA, Elsa. "Venezuela: ¿Potencia Media en el Caribe?” In: Revista de Política Internacional, Ano 1986 - Nro. 2 - Abril-Junio, p. 19.

BARRERA T., A lberto; MARCANO, Cristina. Hugo Chávez Sin Uniforme. Caracas: Ed. Melvin, 2006.

${ }^{53}$ MENDIBLE ZURITA, op. cit. p. 186-187. Jornal do Brasil, 13/11/1977, Folha de S. Paulo, 13/11/1977.
} 
evitar que a entrada abrupta de todo esse dinheiro gerasse alta inflacionária no país ${ }^{54}$. Entre 1929 e 1970, a Venezuela foi o primeiro exportador de petróleo do mundo, tendo sido superado, a partir da crise de 1973, pela Arábia Saudita e pelo Irã. Como parte da política de valorização de preços da OPEP, além das preocupações com o eventual esgotamento das reservas, o governo venezuelano mantinha uma política de controle da produção, o que também dificultava o incremento das vendas de petróleo ao Brasil.

No contexto da crise provocada pela elevação dos preços do petróleo, o porta-voz do Itamaraty, Luiz Felipe Lampreia, reiterou o interesse do Brasil pelo petróleo venezuelano, afirmando: "o desejo do Brasil de comprar petróleo da Venezuela em quantidades maiores, é, não só antigo, mas agora reiterado ${ }^{55}$ ". É bom lembrar que o projeto desenvolvimentista das décadas de 1950-60, privilegiara o transporte rodoviário em detrimento do ferroviário e hidroviário. Esta característica, que foi reforçada durante o regime militar, explica o impacto que a elevação dos preços do petróleo tenha sido muito forte no Brasil. Além de tornar as importações brasileiras mais caras, o choque do petróleo provocou recessão econômica nos países industrializados, acarretando prejuízos para as exportações brasileiras e para o nível de investimentos externos recebidos pelo país. No que se refere à geração de energia, a escassez de petróleo serviu de importante catalisador para os projetos brasileiros de aproveitamento do álcool, da energia nuclear, de construção de novas usinas hidrelétricas e de prospecção de petróleo. Todos esses projetos foram apresentados durante a presidência de Ernesto Geisel $(1974-79) .{ }^{56}$

No final dos anos 1970, a ofensiva diplomática do presidente dos Estados Unidos Jimmy Carter dividiu brasileiros e venezuelanos, criando um impasse político desde que o presidente venezuelano expressara sua adesão à diplomacia de direitos humanos de Jimmy Carter, que tanto desagradou ao governo militar brasileiro. Outro impasse entre os dois países resultara das críticas anteriormente expressas pelo presidente venezuelano ao programa de energia nuclear do Brasil, endossando a condenação dos EUA e da Argentina. Para superar esse outro mal-estar, Andrés Pérez afirmou, em entrevista ao Jornal do Brasil, publicada em

\footnotetext{
54 Jornal do Brasil, 06/10/1977.

55 Jornal do Brasil, 07/10/1977.

Em seu livro de memórias, Lampreia narra mais detalhadamente o papel da diplomacia brasileira nas tentativas do governo brasileiro de atenuar o impacto que os choques do petróleo tiveram sobre o projeto de desenvolvimento nacional. LAMPREIA, Luiz F. O Brasil e os ventos do mundo, Rio de Janeiro: Ob jetiva, 2010.

${ }^{56}$ VIZENTINI, Pau lo G. F. A política externa do Regime Militar brasileiro: multilateralização, desenvolvimento e a construção de uma potência média (1964 - 1985). Porto Alegre: Ed. UFRGS, 1998, p. 198-199.
} 
novembro de 1977, discordar da ideia propalada entre os vizinhos e em boa parte da própria imprensa de seu país de que um "Brasil grande potência" ameaçava os demais países latinoamericanos; ao contrário, dizia acreditar que a presença de um grande país no projeto de integração latino-americana era benéfica. ${ }^{57}$ No entanto, as declarações favoráveis do Presidente venezuelano em relação ao "Brasil grande potência" talvez se expliquem pelo fato de que a economia brasileira, porém, já não apresentava o desenvolvimento vigoroso dos anos do "milagre", deixando de parecer o prenúncio de uma expansão ameaçadora.

Mais do que por razões políticas, o interesse brasileiro em aumentar as importações de petróleo venezuelano naquele momento se viu bloqueado pela erosão da capacidade de pagamento da economia brasileira. Ao choque do petróleo se seguiu a elevação dos juros da dívida externa, inviabilizando a continuidade do modelo de desenvolvimento adotado até ali.

\subsection{COOPERAÇÃO EM INSTÂNCIAS MULTILATERAIS: CONTADORA E CARTAGENA}

Como já foi dito antes, a renda do petróleo conferia à economia venezuelana possibilidade de redistribuição de renda - ainda que desigual - pela mediação do Estado e afiançava a estabilidade política do país. Tal estabilidade econômica e política permitiu que a Venezuela tivesse aspirações diplomáticas elevadas, que foram reforçadas durante o governo de Carlos Andrés Pérez. Na passagem da década de 1970-80, a situação, bastante favorável da Venezuela permitiu que o país passasse a exercer certa liderança regional, especialmente na área da América Central e Caribe. ${ }^{58}$

\footnotetext{
${ }^{57}$ Jornal do Brasil, 13/11/1977. CERVO, op. cit., p. 248, adota um ponto de vista distinto. Ali, diz o autor, sobre Carlos Andrés Pérez: "Não tinha simpatias pelo desenvolvimento brasileiro que podia tolher-lhe o caminho da influência regional, por isso buscou aproximar-se da Argentina e aderiu ao Pacto Andino por razões puramente políticas. As duas áreas de interesse concreto da Venezuela prosseguiam sendo o Caribe e os países bolivarianos". De qualquer maneira, veremos ao longo deste capítulo que Andrés Pérez, se carregava alguma prevenção contra o Brasil, ao menos conseguiu esconder esse sentimento e projetar uma imagem bastante positiva sobre a imprensa brasileira, de maneira geral, até que a crise da dívida "explodisse" em suas mãos, já no final dos anos 1980.

${ }^{58}$ Carlos Andrés Pérez, reforçando o papel de liderança da Venezuela na região, declarou, em 1977, seu apoio às negociações entre o Panamá e os EUA, visando à devolução da soberania deste último sobre o Canal do Panamá. Jornal de Brasília, 12/03/1977.
} 
Nesse mesmo contexto, a resolução dos conflitos reais e potenciais com o Brasil permitia que a diplomacia brasileira reconhecesse esse papel de liderança da Venezuela. Ainda no finalde seu mandato, Andrés Pérez afirmou, em entrevista no palácio de Miraflores:

Cada dia vemos o Brasil mais próximo de nós e mais interessado nas relações bilaterais e multilaterais de caráter regional. Uma prova evidente disso é a forma entusiástica com que o governo brasileiro aderiu ao Sistema Econômico LatinoAmericano (SELA). Esta adesão me deixa muito otimista quanto ao êxito da integração, porque o Brasil, é inegável, tem um peso específico dentro da região e devemos aceitá-lo dessa forma. Isso, porém, não quer dizer que o Brasil esteja buscando uma liderança nem que os demais países estejam dispostos a aceitá-la. ${ }^{59}$

O presidente venezuelano havia anunciado a criação de linhas de crédito para a venda de petróleo para os países latino-americanos em março de 1977, antecipando-se a uma decisão que a OPEP iria tomar no sentido de estabelecer relações comerciais especiais com os países do Terceiro Mundo, levando em conta as dificuldades que a elevação dos preços causara para suas economias.

O sucessor de Carlos Andrés Pérez foi Luis Herrera Campíns (Copei, 1979-1984). Sua gestão transcorreu em meio ao declínio econômico do país, fruto da excessiva dependência das receitas do petróleo, cujos preços declinavam frente à ofensiva dos países industrializados contra a política da OPEP. De fato, os Estados Unidos começaram nesse período a explorar jazidas petrolíferas em seu litoral atlântico, e incentivaram o aumento da participação de outros produtores no mercado, como era o caso do México, do Reino Unido e da Noruega. ${ }^{60}$

A fragilização da posição econômica venezuelana provocou retração do ativismo diplomático que caracterizou a gestão anterior. Mesmo assim, a Venezuela continuou exercendo protagonismo na região da América Central e do Caribe.

A diplomacia venezuelana, nos anos de mandato de Herrera Campíns, pautava-se por cinco diretrizes elencadas pelo estrategista do governo, José Rodriguez Iturbe: a) nãointervenção nos assuntos dos países latino-americanos, b) distância de blocos ideológicos, c) desencorajamento da rivalidade de superpotências na região, d) prestígio da OEA, e) criação de uma nova ordem econômica internacional.

No entanto, apesar de manifestar-se contra intervenções, o governo venezuelano, colaborava, no Caribe e na América Central, na repressão ao comunismo. Cabe mencionar o

\footnotetext{
${ }^{59}$ O Globo, 06/03/1977.

${ }^{60}$ O Globo, 23/02/1978.
} 
fato, noticiado pelos jornais venezuelanos, que, nos primeiros meses de 1980, a Venezuela fornecera armas ao governo salvadorenho, contribuindo para a repressão à insurgência revolucionária que ocorria no país. ${ }^{61}$ Em 1981, o Presidente venezuelano advertiu ao presidente norte-americano recém-eleito, Ronald Reagan, de que o intervencionismo seria rechaçado na América Latina, revelando contradições entre o discurso e a prática política. ${ }^{62}$

A diplomacia venezuelana do governo de Herrera Campíns buscou maior aproximação com os países signatários do Pacto Andino, embora de uma forma mais pragmática do que havia feito seu antecessor, que insistira, sem sucesso, na missão "democratizadora" na região. $^{63}$

Baseados no poder do petróleo, nas condições geográficas e nas divergências ideológicas, a diplomacia venezuelana, nesse período, conferia baixa prioridade às relações com Brasil, Argentina e Uruguai, no Cone $\mathrm{Sul}^{64}$. Este cenário se modificou quando, a partir do início da década de 1980, os países mais desenvolvidos da América Latina já não estavam mais dispostos a continuar seguindo as estratégias norte-americanas para a Guerra Fria e optaram por priorizar os interesses econômicos e geopolíticos da região.

A situação conturbada da América Central provocada por conflitos de natureza diversa abalaram a influência dos EUA na região. Cabe mencionar algumas situações que mostram um contexto bastante convulsionado: a vitória do governo panamenho ao conseguir a devolução do Canal do Panamá e consequente afirmação da soberania panamenha em 1977, a vitória da Revolução Sandinista em 1979, as insurreições contra o governo de El Salvador aliado dos EUA e os movimentos de guerrilha na Guatemala. Ao final da década de 1970, apenas em Honduras e na Costa Rica a fidelidade aos Estados Unidos não estava posta em questão.

No entanto, os conflitos de maior relevância ocorriam em torno do posicionamento dos EUA em relação a Cuba. A Venezuela apoiava o bloqueio a Cuba, ainda que recusasse a utilização de meios militares. Também se opunha a um ataque contra a Nicarágua e ajudava economicamente o regime revolucionário. Em contraposição aos argumentos do Presidente Reagan para dar sustentação às ditaduras latino-americanas, as autoridades venezuelanas

\footnotetext{
${ }^{61}$ Folha de S. Paulo, 02/04/1980.

62 Gazeta Mercantil, 10/08/1981.

63 Ibid, p. 248.

${ }^{64}$ O Estado de S. Paulo, 23/08/1981.
} 
consideravam que a ameaça de infiltração comunista era menos importante do que os desajustes sociais como explicação para a instabilidade política. No entanto, essas discordâncias não impediram que, como estratégia de contenção da ameaça soviética na América Latina, o governo norte-americano se empenhasse na venda de 20 aviões de caça F16 para a Venezuela. O país era importante para os EUA porque, através da diplomacia do petróleo, concedia créditos aos pequenos países da região; tal posição permitia que a Venezuela fosse vista como uma aliada alternativa em face das pressões de Cuba e dos EUA. $^{65}$

Com relação ao Brasil, cabe destacar que o governo militar se recusou a apoiar os projetos intervencionistas dos EUA na América Central. ${ }^{66}$ Esta posição sugeria afastamento em relação ao país do Norte. No entanto, também não sugeria aproximação com seus vizinhos sul-americanos. A imagem de uma potência agressiva e subimperialista que havia se consolidado entre eles a partir do Governo Médici persistia apesar da mudança da política externa no governo de Ernesto Geisel (1974-1979). Nesse período, houve uma disputa entre o Itamaraty e o Conselho de Segurança Nacional, em torno de uma mudança de enfoque da política externa brasileira, que estava em processo de realocação de suas prioridades, enfatizando cada vez mais as tarefas do desenvolvimento econômico em detrimento da preocupação com as questões de segurança. No entanto, essa mudança de orientação da política brasileira demorou a ser percebida por seus vizinhos, que continuaram a temer a projeção militar brasileira. ${ }^{67}$

Apesar da permanência das desconfianças em relação às pretensões do "Gigante brasileiro", a nova política para a América do Sul da gestão de Geisel resultou em abertura para a distensão e aproximação com a Argentina e com a Venezuela, através do Pacto Amazônico orientado por uma política de integração territorial que o Brasil buscava implementar buscando aliança com os demais países da região.

A região amazônica era considerada estratégica para os governos militares do Brasil, que implementaram diversos projetos buscando integrá-la economicamente ao restante do

\footnotetext{
${ }^{65}$ O Estado de S. Paulo, 18/11/1981.

${ }^{66}$ LIMA, Maria R. S. de. “As relações do Brasil com os Estados Unidos: 1964-1990”. In: ALBUQUERQUE, José A. G. (org.). Sessenta Anos de Política Externa Brasileira 1930-1990. Vol. III. O Desafio Geoestratégico. São Paulo: Annablume/NUPRI/USP, 2000, p. 79.

OLIVEIRA, op. cit. p. 199.

${ }^{67}$ Folha de S. Paulo, 06/10/1977. Jornal de Brasília, 08/08/1978.
} 
país. O Pacto Amazônico representava a face internacional dessa mesma estratégia, mas encontrou obstáculos devido ao temor que os países vizinhos tinham em relação à hegemonia brasileira, acrescido ao fato de que havia, historicamente, desinteresse recíproco de aproximação dos países sul-americanos, cada um deles mais voltado para os oceanos ${ }^{68}$. O último país a superar tais receios foi a Venezuela; ${ }^{69}$ sua adesão ao projeto integracionista permitiu que se realizasse, em outubro de 1980, a I Reunião de Chanceleres dos países do Tratado de Cooperação Amazônica. Congregando Bolívia, Brasil, Equador, Colômbia, Guiana, Peru, Suriname e Venezuela, o Tratado buscava concertar as políticas desses países no que dizia respeito à atenção a ser dada às comunidades indígenas, à soberania no uso e aproveitamento dos recursos naturais, à criação de parques nacionais e unidades de conservação, ao desenvolvimento econômico da região em cada país e ao aproveitamento dos rios para transporte ${ }^{70}$. No contexto mais amplo, buscava-se criar um antídoto institucional às manobras de internacionalização da Amazônia. ${ }^{71}$

Maria Helena Capelato, em artigo sobre as relações entre o Brasil e os vizinhos latinoamericanos, demonstrou com detalhes esse processo de distensão. Tal processo foi iniciado durante o governo de Geisel e continuou a operar durante as gestões posteriores. Também remonta á época de Geisel a bipartição da estratégia brasileira para a região, segundo critérios geográficos. Capelato demonstra que os anos de 1974 a 1976 foram de especial ênfase nas relações com os vizinhos da região do Prata, enquanto, a partir de 1977, “o Brasil se movimentou para criar nova política, convidando seus vizinhos do Norte para discutir um tratado para a cooperação no desenvolvimento da bacia amazônica". ${ }^{72}$

Com a chegada do general João Baptista Figueiredo ao poder (1979-1985), a diplomacia brasileira continuou se transformando. A política externa conduzida pelo chanceler Ramiro Saraiva Guerreiro adotava um tom mais reivindicativo frente ao que

\footnotetext{
${ }^{68}$ MAIOR, Luiz A. S. "A diplo macia econômica brasileira no pós-guerra (1964-1990)". In: ALBUQUERQUE, José A. G. (org.). Sessenta anos de política externa brasileira (1930-1990). Diplomacia para o desenvolvimento. São Paulo: Cultura Ed itores/Nupri-USP, V. II, 1996, p. 283.

69 Telegrama n ${ }^{\circ}$ 498, 05/06/1980. De Embaixada do Brasil em Caracas, ao Ministério de Relações Exteriores. PREG TCA (1977 a 2003) Caixa 106.

70 VIZENTINI, op. cit., p. 307.

71 MAIOR, op. cit., p. 284.

${ }^{72}$ CAPELATO, op. cit., p. 307-315.
} 
considerava as injustiças da ordem econômica internacional, em comparação com o que fizeram seus antecessores ${ }^{73}$. Es sa política externa foi assim definida por Paulo Vizentini:

\begin{abstract}
Esforçou-se por manter a autonomia do Brasil num cenário crescentemente desfavorável, conservando fortes traços de continuidade com o Pragmatismo Responsável. Definindo o país como parte do Terceiro Mundo, a diplomacia brasileira continuou a atuar nos fóruns internacionais em convergência com o Movimento Não-Alinhado (embora não o integrando), denunciando as estruturas políticas e econômicas internacionais. (...) A América do Sul, por sua vez, constituía cada vez mais um espaço valorizado pela diplo macia brasileira, incrementando uma cooperação político-econômica, cujo eixo central era o acercamento com a Argentina. Além disso, o Brasil observava com extrema inquietação a crescente pressão americana pela redemocratização no Cone Sul, interpretando o fenômeno como uma estratégia de desarticulação das potências médias e de legitimação do pagamento da dívida externa destas. ${ }^{74}$
\end{abstract}

Em discurso pronunciado ao Congresso, por ocasião de seu primeiro ano como presidente, Figueiredo reafirmou a aproximação com as "nações vizinhas e irmãs da América Latina", baseado em uma política de "igualdade, não intervenção e descontração". E prosseguiu, afirmando:

O Brasil assume integralmente a sua condição de país latino-americano. Acredita que, em conjunto, as nações latino-americanas devem buscar as mais aperfeiçoadas formas de integração regional, que permitam não só acelerar o desenvolvimento e o intercâmbio entre elas, com o realismo e a atenção às potencialidades e necessidades de cada país, senão também que lhes facilite presença mais homogênea nas negociações econômicas com os países desenvolvidos. ${ }^{75}$

Em visita ao Brasil, em dezembro de 1982, Reagan procurou apoio brasileiro para o combate ao que via como ameaça comunista na Nicarágua e em El Salvador. Essa visita fazia parte de um giro pela América Latina que incluía o México e a Venezuela. O presidente estadunidense comparou a ameaça das armas nucleares e dos exércitos convencionais com o perigo representado por "pretensos revolucionários", "armados, a um custo muito elevado pelo preposto de uma potência longínqua, uma potência que esposa uma filosofia alheia às Américas, cujo objetivo é a desestabilização dos nossos governos e das nossas economias". À interpretação de Reagan, o presidente brasileiro João Baptis ta Figueiredo contrapôs a ideia de que "não podem as soluções pluralistas e democráticas prosperar num quadro de pobreza e instabilidade social”. Com essa argumentação, não apenas Figueiredo, mas também a maior

\footnotetext{
${ }^{73}$ Em discurso de abertura da Primeira Sessão Plenária do Fórum das Américas, em São Paulo, 11 de junho de 1979, A zeredo da Silveira disse:

"É preciso, de qualquer modo, que a comunidade internacional evolua para a superação de toda uma série de atitudes protecionistas, que afetam o acesso dos países em desenvolvimento às duas áreas onde se concentra a essência mes ma da vida econômica atual". Documento do Arquivo do Itamaraty, armazenado em PREG TCA (1977 a 2003) Caixa 106.

${ }^{74}$ VIZENTINI, op. cit., p. 275-276.

${ }^{75}$ Resenha de Política Externa do Brasil. 1980, n.24, p. 3. apud VIZENTINI, op.cit., p. 276.
} 
parte dos líderes latino-americanos buscou excluir a crise centro-americana do contexto da disputa entre os Estados Unidos e a União Soviética. Ao final de suas observações feitas em resposta aos argumentos do presidente norte-americano, o presidente brasileiro enfatizou a sua confiança na capacidade dos países latino-americanos de resolver a crise por seus próprios esforços e em seus próprios termos:

Cremos, firmemente, que naquela região (América Central), como nas demais, o direito dos povos e a soberania dos governos devem ser respeitados sem ingerências ou pressões externas. Vemos com grande esperança a contribuição que podem dar à pacificação dos espíritos e à pesquisa de soluções democráticas e livres os países latino-americanos que, como o México, a Venezuela e a Colômbia, aliam uma inestimável experiência política a u ma tradicional presença naquela região. ${ }^{76}$

Nesse cenário de acirramento da Guerra Fria, os representantes dos países latinoamericanos temiam, tanto o transbordamento dos conflitos na região, caso a possibilidade de que as forças em disputa estabelecessem bases de operações em qualquer país do subcontinente, quanto a ingerência norte-americana no sentido de uma ocupação militar direta.

Segundo Marcelo Santos, nesse contexto, os fatos mostravam que, não só "os governos, mas também os movimentos sociais e partidos políticos latino-americanos eram favoráveis e lutavam pelo rompimento total ou pela reformulação das condições de dependência em que se encontram diante dos EUA". ${ }^{77}$

A situação exigia a busca de soluções para impedir formas de intervenção dos EUA. O México, a Venezuela e a Colômbia, por sua proximidade geográfica com a região, assim como pelos seus antecedentes de cooperação política, eram os países mais capacitados a fornecer alternativas para a escalada dos confrontos. Esses três países haviam apoiado as negociações do Panamá com os Estados Unidos para a transferência de soberania sobre o Canal, que resultaram no acordo de 1977. A Venezuela e o México haviam assinado, em 1980, os Acordos de San José, pelos quais conferiam auxílio econômico aos países centroamericanos e caribenhos, e também assinaram uma declaração conjunta sobre os conflitos entre Nicarágua e Honduras em setembro de $1982 .{ }^{78}$ Essa declaração conjunta foi precedida

\footnotetext{
${ }^{76}$ Apud ALEIXO, José C. P. “O Brasil e a América Central”, In: Revista Brasileira de Política Internacional. n 101-104, 1983, p. 31.

${ }^{77}$ SANTOS, Marcelo. O poder norte-americano e a América Latina no pós-guerra fria. São Paulo: Annablume; Fapesp, 2007, P. 44.

78 GONZA LO, Marisol de. "La Significación del Grupo Contadora como Actor Internacional”, In: Revista de Política Internacional. Ano 1986, nº 3, p. 18.
} 
pela troca de correspondências a respeito do assunto, em um primeiro momento entre os presidentes da Venezuela, Luis Herrera Campíns, e do México, José López Portillo.

Em outubro de 1982, os dois presidentes propuseram um encontro entre o presidente de Honduras, Roberto Suazo Córdova e o Coordenador da Junta de Governo de Reconstrução Nacional da Nicarágua, Daniel Ortega que aceitou a proposta do encontro. No entanto, ele não se realizou em razão da negativa de Suazo Córdova, que alegou compromissos em seu país. Naquele mesmo mês, o Panamá manifestou interesse em participar da mediação. A esse país não convinha o recrudescimento dos conflitos porque sediava o Comando Sul do Exército dos Estados Unidos e seria afetado pelas operações militares. ${ }^{79}$ Ademais, as desconfianças panamenhas em relação aos Estados Unidos eram altas naquele momento. Suspeitava-se de envolvimento da CIA no acidente aéreo em que morreu o líder nacionalista do país, Omar Torrijos.

Diante do acirramento dos conflitos na América Central e recrudescimento da Guerra Fria durante a gestão de Ronald Reagan, diplomatas de diversos países se reuniram para discutir medidas capazes de fazer frente ao intervencionismo dos EUA na região. Os chanceleres do México, Bernardo Sepúlveda Amor, da Colômbia, Rodrigo Lloredo Caicedo, da Venezuela, José Alberto Zambrano Velasco, e do Panamá, Juan José Amado se reuniram na ilha de Contadora, Panamá, no dia 8 de janeiro de 1983, dando origem ao que ficou conhecido como Grupo de Contadora. O Grupo atuou ao longo da década como um mecanismo de consulta política para a solução dos conflitos internos da América Central, e acabou favorecendo a aproximação dos países da América Latina. Tal aproximação abriu terreno para o estreitamento das relações entre Brasil e Venezuela, ainda que a diplomacia brasileira tenha aderido ao Grupo apenas dois anos e meio depois da sua criação.

Nesse contexto no qual o Brasil se aproximava de seus vizinhos, os esforços dos diplomatas para que fosse apagada a imagem de país imperialista ainda não tinham sido compensados completamente. Mas o apoio dado à Argentina na questão das Malvinas contribuiu muito nesse sentido. ${ }^{80}$

\footnotetext{
${ }^{79}$ MURILlO VIAÑA, Fernando. América Latina en los Ochenta. Madrid: Ediciones Cultura Hispánica, 1986, p. 149.

${ }^{80} \mathrm{O}$ Brasil expressou oficialmente seu apoio à reivind icação territorial, mas não à utilização de meios militares para a reintegração das Malvinas ao território argentino. Mas extraoficialmente, o apoio brasileiro ao governo argentino incluiu a venda de aviões de combate. VIZENTINI, op. cit., p. 273.
} 
A atitude do governo brasileiro em relação à Argentina contrastava com o apoio que os Estados Unidos concederam ao Reino Unido na Guerra das Malvinas, que significou o reconhecimento definitivo do fracasso do Tratado Interamericano de Assistência Recíproca

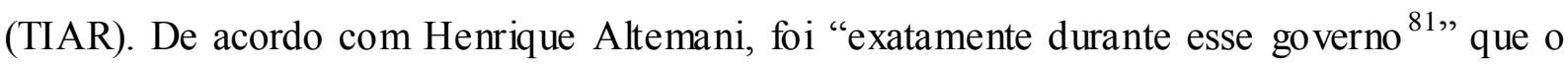
Brasil iniciou um processo duradouro e coerente de aproximação com a América Latina:

\begin{abstract}
O acerto com a Argentina sobre a exp loração dos recursos hidrelétricos, por meio do Acordo Tripartite Argentina-Brasil-Paraguai (outubro de 1979) terá um papel fundamental para a remoção de desconfianças em relação ao Brasil. De outro lado, o Tratado de Cooperação Amazônica (julho de 1978), em conjunto com a participação brasileira nos processos negociadores dos conflitos Peru-Equador e Argentina-Chile são peças que possibilitam a ampliação de um clima de confiança em relação ao Brasil. (...) Essa latino-americanização da política externa brasileira vai, ainda, ser mais realçada com as dificuldades de inserção internacional em decorrência das crises econômicas e financeiras que se abatem, principalmente, sobre o Terceiro Mundo na metade dos anos 1980. Nesse sentido, pode-se aventar a hipótese de que a retomada da inserção brasileira na região decorre, de um lado, das maiores dificuldades encontradas em outros espaços e, de outro, de uma reversão na imagem negativa que o País detinha no espaço latino-americano. ${ }^{82}$
\end{abstract}

\title{
1.3 CRISE ECONÔMICA E SEUS EFEITOS NA VENEZUELA E NO BRASIL
}

Antes de analisarmos as contribuições do Grupo de Contadora para o fortalecimento das relações bilaterais entre Brasil e Venezuela, convém fazer referência à situação econômica da região abalada pela crise da dívida externa. A elevação das taxas de juros praticadas no mercado financeiro internacional atingiu as economias latino-americanas, que haviam feito empréstimos de vulto durante a década de 1970. Eles foram concedidos a taxas de juros flutuantes, condicionadas à variação das taxas dos governos dos Estados Unidos e do Reino Unido. A elevação dos juros nesses países levou ao aumento abrupto dos serviços da dívida latino-americana, num momento em que os preços das matérias primas e outras commodities

Cabe esclarecer que o governo militar brasileiro temia a possibilidade de uma guerra com a Argentina A recente desclassificação de arquivos secretos e inéditos do Estado-Maior das Forças Armadas revelou a criação, em agosto de 1978, de um "Plano de Informações Estratégicas Militares", que consistia em verdadeiras redes de espionagem de militares e diplomatas brasileiros nos países vizinhos da América do Sul. Também foi revelado o temor que a alta cúpula das Forças Armadas brasileiras tinha de uma possível guerra contra a Argentina, nos anos finais da década de 1970. O Presidente Geisel, contudo, recusou pedido de dotação orçamentária para reaparelhamento baseado nessa hipótese de conflito. Segundo o general Tácito Oliveira, então min istro -chefe do EMFA: "(O Presidente) disse que não há nenhuma possibilidade de uma guerra no curto prazo e constitui um esforço muito grande despender uma quantia dessa, sem ter em vista nenhuma guerra iminente". O Estado de $S$. Paulo, 11/08/2013.

${ }^{81}$ OLIVEIRA, op. cit., p. 194.

${ }^{82}$ Ibidem, p. 198-199. 
entravam num ciclo de baixa no mercado internacional. Em poucos meses, os países latinoamericanos viram aumentar os seus encargos financeiros, ao mesmo tempo em que diminuíam suas receitas de exportação. Esse mecanismo enfraqueceu sobremaneira a capacidade de atuação internacional dos países da região.

No mesmo momento em que esses países se posicionavam de forma ofensiva em relação à política internacional, articulando um esforço até então inédito de cooperação para afastamento da ingerência norte-americana na América Latina, suas economias se encontravam em situação calamitosa que persistiu durante toda a década de $1980 .{ }^{83} \mathrm{O}$ ano de 1982, que precedeu imediatamente a formação do Grupo de Contadora, é considerado pela historiografia como o marco inicial da "crise da dívida": nesse ano o México declarou moratória por falta de meios de pagamento. A moratória mexicana logo foi seguida por dificuldades de pagamentos enfrentadas pelo Brasil, Argentina, Peru e Venezuela, conferindo contornos continentais ao problema. ${ }^{84}$

A crise que se abateu sobre a América Latina nos primeiros anos da década de 1980 foi decorrente de circunstâncias adversas no cenário econômico internacional. Cabe destacar, primeiramente, o segundo choque do petróleo em consequência da guerra entre o Irã e o Iraque (1980-88). Embora a crise tenha sido benéfica para os países exportadores de petróleo (como era o caso da Venezuela), significou mais um golpe para o desenvolvimento econômico de países como o Brasil, importadores líquidos daquela matéria prima. O encarecimento das importações de petróleo tinha que ser respondido através da obtenção de moeda forte (dólar), seja pela via dos empréstimos junto ao sistema financeiro internacional, seja pela via do incremento das exportações. Essas possíveis soluções, contudo, estavam se esgotando pelo fato de que os países industrializados responderam à recessão, que também os afetou, através desses mesmos mecanismos. Os Estados Unidos, para financiar o aumento de seus gastos com o petróleo, e para estancar a crescente inflação, elevaram a taxa de juros (1979), provocando um afluxo de capitais para o seu mercado, o que tornou seus empréstimos menos disponíveis aos países do Terceiro Mundo.

À elevação da taxa de juros norte-americana, seguiram-se movimentos similares nos mercados da Europa, e as dívidas latino-americanas, cujos juros estavam vinculados às

\footnotetext{
${ }^{83}$ VIZENTINI, Paulo G. F. O descompasso entre as nações. Rio de Janeiro: Record, 2004, p. 97-98.

${ }^{84}$ Jornal de Brasília, 28/12/1982.
} 
oscilações das taxas dos EUA e do Reino Unido, multiplicaram-se subitamente. Outra medida adotada pelos países industrializados para melhorar a situação de seu balanço de pagamentos foi a diminuição de suas importações, o que também dificultava o acesso dos países em desenvolvimento aos dólares necessários para fazer frente à alta do preço do petróleo e dos juros de sua dívida. A situação foi agravada pelo despreparo das instituições financeiras em lidar com o problema, como podemos verificar através da seguinte citação do Relatório sobre o Desenvolvimento Mundial 1981, do Banco Mundial: “Os países em desenvolvimento terão mais dificuldade em gerir a sua dívida, no entanto [as tendências] não anunciam nenhum problema generalizado". 85

Em maio de 1983, a embaixada brasileira em Caracas enviou um telegrama ao Ministério das Relações Exteriores, contendo o documento "Bases para uma resposta da América Latina à crise econômica internacional", elaborado em conjunto pela Comissão Econômica para a América Latina e Caribe (CEPAL), ligada à Organização das Nações Unidas (ONU) e pelo SELA, por solicitação do presidente do Equador. ${ }^{86}$ Esse documento de 70 páginas continha algumas hipóteses sobre as causas da crise e uma série de recomendações para a sua superação. Após alertar para a gravidade da situação econômica, considerada pior do que a Grande Crise de 1929-33, o documento apontava para os efeitos negativos da elevação dos juros e da diminuição da demanda por commodities:

Con todo, el rasgo más distintivo de la crisis ha sido el nivel excepcionalmente alto
alcanzado por las tasas reales de interés. En efecto, como resultado de la alta
prioridad que los países industrializados otorgaron en años recientes a la reducción
de la inflación, de la considerable magnitud de los déficit fiscales y, sobretodo, del
enorme énfasis que en dicha tarea se dio en algunos de ellos al control de la oferta
monetaria, las tasas de interés subieron marcadamente en los principales centros
financieros internacionales a partir de 1978, y en términos reales alcanzaron durante
el bienio $1980-1981$ niveles comparados solo a los registrados durante la Gran
Depresión. (...) El nivel excepcionalmente alto de las tasas reales de interés ha
contribuido, asimis mo, a reducir fuertemente la demanda de inventarios, entre ellos
los de productos básicos, lo que, a su vez, explica en gran parte el deterioro de los
términos de intercambio de las economías en desarrollo. ${ }^{87}$

Os autores desse relatório entendiam que a crise, originada a partir dos países industrializados, contagiara as economias latino-americanas de três maneiras. Em primeiro lugar, a já citada redução da demanda pelos produtos básicos que logo atingiu a demanda por

\footnotetext{
85 Apud MILLET, Damien; TOUSSAINT, Éric. 50 perguntas 50 respostas sobre a dívida, o FMI e o Banco Mundial. São Paulo: Boitempo, 2006, p. 63.

86 Telegrama $n^{\circ}$ 169, 26/05/1983. De Afonso Arinos de Mello-Franco, Embaixador, à Secretaria de Estado. PREG TCA (1977 a 2003) Caixa 106.

${ }^{87}$ CEPAL/SELA. Bases para una respuesta de América Latina a la crisis económica internacional. P. 5-6.
} 
petróleo que resultou na contaminação da Venezuela pela crise. Em segundo lugar, a alta das taxas de juros elevou o valor dos pagamentos do serviço das dívidas. E, por último, o capital antes disponível para empréstimos afluiu para os países industrializados, acabou levando os países da América Latina à asfixia financeira.

Uma das tentativas de solucionar esse impasse consistia na desvalorização das moedas nacionais, o que tornava os seus produtos mais baratos para os países do Norte, que os compravam em moedas fortes. Havia um inconveniente nessa estratégia: a desvalorização cambial tornava as importações mais caras, inflacionando os preços. É importante detalhar esses mecanismos econômicos da crise, porque eles condicionaram as escolhas políticas realizadas pelas autoridades brasileiras e venezuelanas ao longo das décadas de 1980 e 1990, afetando as relações bilaterais.

A Venezuela foi golpeada, no curto espaço de tempo de cinco anos, entre 1978 e 1983, por um duplo revés: a elevação das taxas de juros da dívida, causadora da elevação nas taxas de juros das dívidas contratadas em regime flutuante pelos países latino-americanos, e a contraofensiva dos países compradores de petróleo, que não permaneceram passivos frente ao aumento dos preços conseguido pela OPEP, passando a incentivar a produção em seus próprios países ou adquirir o produto fora da organização que controlava abusivamente a oferta. A queda das receitas da exportação do petróleo coincidiu, para a Venezuela, com o momento de maior pressão sobre seu orçamento, e o impasse gerado por essa situação pressionou, por sua vez, o sistema político venezuelano, assentado sobre a redistribuição dos benefícios do petróleo. Marcano e Barrera descreveram os primeiros anos da década de 1980, que marcaram o governo de Herrera Campíns, nos seguintes termos:

Los últimos meses del gobierno de Carlos Andrés Pérez (1974-1979) transcurren en medio de escándalos de corrupción, que allanan el camino para el triunfo de la oposición. En las elecciones presidenciales de diciembre de 1978, los venezolanos confían la presidencia al de mócrata cristiano Lu is Herrera Campíns, quien durante la transmisión de mando as egura que recibe 'un país hipotecado' por la deuda externa; Después de la bonanza petrolera que disfrutó el país durante la administración Pérez llega la hora de las vacas flacas. ${ }^{88}$

Alejandro Mendible Zurita identificou, precisamente no mecanismo de financiamento daqueles anos prósperos, a raiz do endividamento venezuelano, que seria fatal para o advento da crise venezuelana da década de 1980:

\footnotetext{
${ }^{88}$ BA RRERA T.; MA RCANO, op. cit., p. 88.
} 
Es un país que tiene entonces una economía rentista, altamente dependiente de un producto. Se ha hecho en el caso de Guayana [região oriental da Venezuela que recebeu investimentos para a diversificação econômica] esa sustitución de importaciones tardía, en el 1950, 1960 y tal. Pero es una economía en que el petróleo es fundamental. En ese momento, hay un crecimiento con endeudamiento. Porque ahí empie za el endeudamiento. ${ }^{89}$

No começo de 1983 a situação das reservas venezuelanas já estava insustentável, devido à fuga de capitais, à elevação dos juros da dívida e à diminuição das receitas do petróleo. Em 18 de fevereiro, o dia que ficou conhecido como "sexta-feira negra", o governo venezuelano anunciava o abandono da taxa fixa de câmbio: ela passava a ser flutuante, de acordo com o mercado ${ }^{90}$. Na semana que antecedeu a desvalorização da moeda, as operações de câmbio já haviam sido bloqueadas, para controlar a saída de divisas do país, cujas reservas haviam diminuído de US\$ 16 bilhões, em outubro de 1982, para US\$ 8,7 bilhões em fevereiro de 1983. Também começaram a ser estudados outros mecanismos não cambiais para o controle de importações ${ }^{91}$. Tal cenário foi relatado pelo embaixador brasileiro na Venezuela nos seguintes termos: "Esta é a situação de quebra virtual das finanças venezuelanas". 92

À "sexta-feira negra" seguiu-se, já em março, a primeira moratória venezuelana, quando Arturo Sosa, ministro da Fazenda da Venezuela, anunciou a decisão do governo de suspender o pagamento do principal da dívida pelo menos até o dia $1^{\circ}$ de julho, e de recorrer ao FMI para refinanciamento. ${ }^{93}$ Contudo, após o relatório do FMI ao governo venezuelano, houve uma mudança de planos: as autoridades consideraram excessivamente rigorosas as recomendações do Fundo e incompatíveis com a realidade do país. Em ano eleitoral, o partido no poder não poderia executar as mudanças solicitadas sem que isso significasse a derrota nas eleições. ${ }^{94}$

À exceção do Brasil, todos os demais países da América Latina apresentavam acentuado predomínio de produtos básicos em sua pauta exportadora. E mesmo o Brasil apenas na entrada da década de oitenta passara a exportar mais produtos manufaturados e

\footnotetext{
${ }^{89}$ Prof. Ale jandro Mendible Zurita. Entrev ista ao autor. Caracas, 02/02/2012.

${ }^{90}$ Gazeta Mercantil, 18/03/1983.

91 Jornal de Brasília, 22/02/1983.

92 Telegrama $n^{\circ}$ 170, 25/02/1983. De A fonso Arinos de Mello-Franco, Embaixador em Caracas, para o Ministério das Relações Exteriores. Confidencial. Microfilmes, Telegramas recebidos, 1983.

93 Telegrama $n^{\circ}$ 268, 29/03/1983. De Afonso Arinos de Mello-Franco, Embaixador em Caracas, para o Ministério das Relações Exteriores. Ostensivo. Microfilmes, Telegramas recebidos, 1983.

94 Telegrama $\mathrm{n}^{\circ}$ 300, 05/04/1983. De A fonso Arinos de Mello-Franco, Embaixador em Caracas, para o Ministério das Relações Exteriores. Confidencial. Microfilmes, Telegramas recebidos, 1983.
} 
semimanufaturados do que produtos básicos, ${ }^{95}$ permanecendo a receita de exportação de commodities um elemento fundamental da economia brasileira. A dependência de produtos básicos para sustentar os superávits comerciais acabou se revelando mais uma debilidade na estrutura econômica desses países quando eclodiu a crise. Isto porque os preços dos alimentos, bebidas, metais e minerais no mercado internacional caíram consideravelmente a partir daqueles anos. ${ }^{96}$

A economia brasileira continuou crescendo durante os anos de 1979 e 1980, embora já não apresentasse o mesmo desempenho dos anos do "milagre". Mas em 1981 o Brasil registrou taxa de crescimento negativa pela primeira vez no pós-guerra. ${ }^{97}$ Marcílio Marques Moreira, que foi ministro da Fazenda durante o governo de Fernando Collor de Mello (19901992), assim descreveu aquela conjuntura:

No momento em que se tornava clara a necessidade de ajustes estruturais, um choque externo, de dimensão e alcance sem precedentes, agregou novo elemento agravante ao já doloroso processo de transição. Seus principais elementos foram: o segundo choque do petróleo; a escalada das taxas internacionais de juros; recessão mundial generalizada, o que significava mercados declinantes para nossos produtos de exportação; preços de matérias primas em queda; e crise da dívida externa. ${ }^{98}$

Em setembro de 1982, quando o México declarou a interrupção dos pagamentos relacionados à dívida externa, a reação dos principais bancos internacionais foi a de interromper as negociações de novos empréstimos aos países da América Latina, afetando também o Brasil. Segundo Paulo Nogueira Batista Jr., ${ }^{99}$ este foi o "golpe de misericórdia" contra a economia brasileira, e pode ser comparado ao que representou a "sexta-feira negra" para a Venezuela. A pressão que o pagamento do serviço da dívida passou a exercer sobre o balanço de pagamentos, com o agravante de que os bancos se recusavam a conceder novos empréstimos, colocou para o governo brasileiro a obrigação de renegociar o reembolso da dívida. ${ }^{100}$

Essa conjuntura recessiva fez com que o Brasil tivesse que recorrer ao Fundo Monetário Internacional (FMI) para obter, além de empréstimos em moeda forte, a credibilidade que os

\footnotetext{
${ }^{95}$ KUNZLER, Jacob P. Mercosul e o Comércio Exterior. $2^{\text {a }}$ Ed. São Paulo: Aduaneiras, 2002, p. 266.

${ }^{96}$ MILLET; TOUSSAINT, op. cit., p. 66.

${ }^{97}$ MAIOR, op. cit, p. 270.

${ }^{98}$ MOREIRA, Marcílio M., "O Brasil e o novo contexto econômico internacional”. In ALBUQUERQUE, op. cit., p. 25.

${ }^{99}$ Bat ista Jr. integrou a equipe do Ministério da Fazenda que elaborou o plano da moratória de 1987.

${ }^{100}$ BATISTA JR. Paulo N. Da crise internacional à moratória brasileira. Rio de Janeiro: Paz e Terra, 1988, p. 65.
} 
bancos agora lhe negavam. A impopularidade desse recurso ao Fundo fez com que o ministro do Planejamento Delfim Neto e sua equipe negassem a intenção de negociar até as eleições de novembro daquele ano, para não prejudicar os candidatos do governo. Passadas as eleições, porém, foi anunciada a abertura das negociações. O fim definitivo do ciclo de crescimento econômico retirou um pilar de legitimidade sobre o qual se sustentavam os governos militares e contribuiu para a redemocratização. ${ }^{101}$ As negociações não foram fáceis, porém, conforme as palavras de Paulo Vizentini:

O ministro Delfim Neto, que voltaria à direção da economia, conduziu difíce is negociações com o FMI, o qual exigia a aplicação de um programa ainda mais recessivo para sanear as finanças e liberar novos empréstimos. A estratégia brasileira foi a de ganhar tempo, prometendo e não cumprindo, enquanto aceitava alguns itens do programa mas manobrava para tentar manter o projeto de desenvolvimento. Este, concretamente, ingressava num processo de desagregação, temperado por medidas paliativas e, geralmente, contraditórias. ${ }^{102}$

O auxílio do FMI contribuiu muito pouco para a solução do problema da dívida externa. Enquanto insistia na necessidade de aprofundamento das reformas econômicas (corte de gastos do Estado, privatizações, desvalorização cambial para aumentar a competitividade das exportações), o papel do Fundo foi o de emprestar dinheiro que deveria ser usado para o pagamento do próprio serviço da dívida. Dessa forma, o Brasil se endividava ainda mais para fazer frente aos elevados valores desse serviço. Entre os anos de 1983 e 1986, o Brasil pagou US\$ 36 bilhões, dos quais US\$ 21 bilhões tiveram como destino os bancos comerciais, que se recusavam a oferecer novos empréstimos. ${ }^{103}$

Tal era o contexto internacional que pressionava a diplomacia dos dois países a buscarem a diversificação de suas relações comerciais. Para a Venezuela, era imprescindível elevar as vendas de petróleo, ampliando o leque de compradores, uma vez que os mercados dos países industrializados se encontravam em recessão. O Brasil apareceu, então, como potencial comprador, e a diplomacia venezuelana passou a gestar o incremento de suas vendas de petróleo. No caso brasileiro, a meta era diversificar os compradores de produtos industrializados, que pudessem gerar as divisas necessárias para o pagamento dos crescentes juros da dívida. Esses foram os temas comerciais mais importantes ao longo do período que abrange este estudo, como veremos adiante.

\footnotetext{
${ }^{101}$ SKIDMORE, Thomas E. Brasil: de Castelo a Tancredo. Rio de Janeiro: Paz e Terra, $4^{\text {a }}$ Ed., 1991, p. 451452.

102 VIZENTINI, Paulo G. F. A política externa do Regime Militar brasileiro: multilateralização, desenvolvimento e a construção de uma potência média (1964 - 1985). Porto Alegre: Ed. UFRGS, 1998, p. 273. ${ }^{103}$ BATISTA JR., op. cit., p. 36-37.
} 
Para fazer avançar os temas que exigiam cooperação multilateral, como era o caso da guerra na América Central e da dívida externa, e os temas comerciais bilaterais, os dois países precisaram construir uma relação de confiança que superasse as antigas desconfianças de caráter geopolítico. Essas desconfianças ganhavam materialidade na região fronteiriça entre os dois países, que em 1983 não estavam sequer demarcadas corretamente. Por se tratar de regiões distantes dos centros de povoamento e atividade econômica, tanto no caso do Brasil quanto no caso venezuelano, a região de fronteira era escassamente povoada, mal demarcada e vulnerável às atividades irregulares de garimpeiros, principalmente oriundos do lado brasileiro, mas que atuavam em território venezuelano, ocasionalmente se envolvendo em conflitos com indígenas e forças de segurança daquele país.

Um exemplo da sensibilidade dos temas fronteiriços na relação bilateral nos é fornecido pela repercussão, na imprensa venezuelana, da suposta criação de uma unidade de "ação rápida" do exército brasileiro para atuar na região de fronteira com a Guiana e a Venezuela. No caso, foi o jornal El Diario de Caracas que reportou matéria de $O$ Estado de $S$. Paulo, e a notícia foi repassada pelo embaixador brasileiro ao Ministério das Relações Exteriores. ${ }^{104} \mathrm{~A}$ medida era uma resposta à tensão crescente na região. Fontes militares teriam dito a $O$ Estado de $S$. Paulo que o Brasil negara diversos pedidos da Venezuela para usar território brasileiro para ações contra a Guiana, em janeiro de 1982. A Venezuela reivindicava - e continua reivindicando - uma região atualmente sob a soberania da Guiana, chamada Essequibo, e que corresponde a cerca de $70 \%$ do território atual daquele país.

A guerra esteve a ponto de acontecer durante o aquele ano, e a possibilidade de um conflito armado só foi relativamente afastada após a malsucedida guerra da Argentina contra o Reino Unido, em que os Estados Unidos apoiaram seu aliado da OTAN, como anteriormente mencionado. É fato que em diversos momentos nas décadas finais do século XX o Brasil se viu obrigado a declarar neutralidade na disputa entre a Guiana e a Venezuela, frente às tentativas das partes de envolver o vizinho. Ainda em 1983, havia políticos venezuelanos que defendiam abertamente a invasão da Guiana como forma de resolver o

\footnotetext{
104 Telegrama $n^{\circ}$ 342, 18/04/1983. De Afonso Arinos de Mello-Franco, Embaixador em Caracas, para o
} Ministério das Relações Exteriores. Confidencial. Microfilmes, Telegramas recebidos, 1983. 
litígio territorial. Tal era o caso do ex-senador Luis Beltrán Prieto Figueroa, que expressou essas ideias no jornal de grande circulação El Nacional. ${ }^{105}$

Em paralelo com tais desenvolvimentos políticos, os dois países buscavam reforçar suas exportações, como forma de gerar receita para o pagamento da dívida externa e compensar a desaceleração do comércio com os países industrializados. Em fevereiro de 1983, o embaixador brasileiro em Caracas relatou seus esforços para concretizar a venda de aviões de treinamento militar EMB - 312 Tucano, à Força Aérea venezuelana. Também havia empresas estadunidenses oferecendo aviões à Venezuela, e o Brasil era o único país latinoamericano capaz de competir com os Estados Unidos nesse tipo de comércio. ${ }^{106}$

A Venezuela, porém, encontrava dificuldades para aumentar as vendas de petróleo para o Brasil. O mercado brasileiro era abastecido pelos fornecedores do Oriente Médio, região que era também a maior compradora de armas fabricadas no Brasil. Durante a década de 1980, a vinculação comercial entre fluxos de petróleo e de armas foi uma constante, e veremos que ela também se manifestou nas relações entre o Brasil e a Venezuela. Durante aqueles primeiros anos da década, porém, o comércio bilateral de petróleo diminuiu. ${ }^{107}$ Outra dificuldade para o incremento daquele comércio era a própria crise econômica em que estavam envolvidos os dois países. Em abril, a Venezuela chegou a suspender embarques de petróleo ao Brasil por atraso nos pagamentos. O incidente só foi superado por uma decisão política do presidente da PDVSA, Humberto Calderón Berti, em setembro daquele ano. ${ }^{108}$

Em sentido oposto, a crise também fragilizava a capacidade compradora da Venezuela. A escassez de dólares, que eram usados para o pagamento dos juros da dívida, levou a que o go verno venezuelano instituísse barreiras para as operações de câmbio, vitais para a execução do comércio exterior. As restrições incidiam sobre as atividades do escritório do Banco do Brasil em Caracas. Uma vez que era esse banco que intermediava o comércio das empresas brasileiras com aquele país, tais restrições criaram uma espécie de barreira não tarifária ao

\footnotetext{
105 Telegrama $\mathrm{n}^{\circ}$ 154, 22/02/1983. De Afonso Arinos de Mello-Franco, Embaixador em Caracas, para o Ministério das Relações Exteriores. Ostensivo. Microfilmes, Telegramas recebidos, 1983.

106 Telegrama no 96, 02/02/1983. De A fonso Arinos de Mello-Franco, Embaixador em Caracas, para o Minis tério das Relações Exteriores. Confidencial. Microfilmes, Telegramas recebidos, 1983.

Telegrama nº 99, 03/02/1983. De Afonso Arinos de Mello-Franco, Embaixador em Caracas, para o Ministério das Relações Exteriores. Secreto. Urgente. Microfilmes, Telegramas recebidos, 1983.

107 Telegrama $\mathrm{n}^{\circ}$ 260, 24/03/1983. De Afonso Arinos de Mello-Franco, Embaixador em Caracas, para o Ministério das Relações Exteriores. Confidencial. Microfilmes, Telegramas recebidos, 1983.

108 Telegrama $\mathrm{n}^{\mathbf{0}}$ 904, 20/09/1983. De Afonso Arinos de Mello-Franco, Embaixador em Caracas, para o Ministério das Relações Exteriores. Secreto. Microfilmes, Telegramas recebidos, 1983.
} 
comércio. ${ }^{109}$ Mas a Venezuela também usou a ele vação de tarifas para barrar o escoamento de dólares. Tal foi o caso da elevação de tarifa sobre a importação de madeiras, que impactou principal produto de exportação do Território de Roraima ao país vizinho. Nem mesmo a proposta dos empresários roraimenses de comprar calcário, cimento e ferro da Venezuela foi capaz de motivar o cancelamento da sobretaxa, que incidia sobre as exportações de terceiros países também. ${ }^{110} \mathrm{O}$ problema com a exportação de madeira de Roraima tanto exasperou o embaixador Afonso Arinos que ele chegou a pedir, em dezembro, que o Brasil preparasse a retaliação comercial à Venezuela, na forma de embargo de suas compras. ${ }^{11}$

Ainda assim, a ofensiva comercial brasileira prosseguia, e em abril empresas brasileiras do ramo de siderurgia, em especial a Açominas, manifestaram interesse em participar das obras paralisadas da Siderzulia, no que eram ajudadas pelo embaixador. ${ }^{112} \mathrm{Em}$ junho, uma missão empresarial e governamental venezuelana viajou ao Brasil, a convite da General Motors, para ouvir propostas de compra de partes e peças automotrizes que substituíssem aquelas importações que a Venezuela já fazia dos EUA, pagando em dólares. ${ }^{113}$

O ministro da Fazenda do Brasil, Ernane Galvêas, visitou a Venezuela entre 11 e 12 de julho de 1983. Galvêas manteve encontros com o presidente Herrera Campíns, com os ministros da Fazenda, Meio Ambiente e Agricultura, para tratar de convênios de pagamento para facilitar o comércio entre os dois países. ${ }^{114}$ Mais tarde, entre os dias 30 de julho e 3 de agosto de 1983, o chanceler José Alberto Zambrano Velasco esteve no Brasil, a convite do Comitê Jurídico Interamericano, sem que fosse realizado qualquer encontro para discussões das relações bilaterais. ${ }^{115}$

Em dezembro de 1983, quando chegou o momento das eleições na Venezuela para a escolha do sucessor de Herrera Campíns, a possibilidade de guerra entre aquele país e a

\footnotetext{
109 Telegrama $\mathrm{n}^{\mathbf{o}}$ 317, 12/04/1983. De Afonso Arinos de Mello-Franco, Embaixador em Caracas, para o Ministério das Relações Exteriores. Confidencial. Microfilmes, Telegramas recebidos, 1983.

110 Telegrama $n^{\circ}$ 326, 13/04/1983. De Afonso Arinos de Mello-Franco, Embaixador em Caracas, para o Ministério das Relações Exteriores. Confidencial. Microfilmes, Telegramas recebidos, 1983.

111 Telegrama $\mathrm{n}^{\circ}$ 1191, 02/12/1983. De Afonso Arinos de Mello-Franco, Embaixador em Caracas, para o Ministério das Relações Exteriores. Secreto. Microfilmes, Telegramas recebidos, 1983.

112 Telegrama $n^{\circ}$ 315, 11/04/1983. De Afonso Arinos de Mello-Franco, Embaixador em Caracas, para o Ministério das Relações Exteriores. Confidencial. Microfilmes, Telegramas recebidos, 1983.

113 Telegrama $\mathrm{n}^{\circ}$ 521, 15/06/1983. De Afonso Arinos de Mello-Franco, Embaixador em Caracas, para o Ministério das Relações Exteriores. Ostensivo. Microfilmes, Telegramas recebidos, 1983.

114 Telegrama $n^{\circ}$ 663, 22/07/1983. De Afonso Arinos de Mello-Franco, Embaixador em Caracas, para o Ministério das Relações Exteriores. Secreto. Microfilmes, Telegramas recebidos, 1983. Libro Amarillo correspondente ao ano de 1988, p. 250.

${ }^{115}$ Libro Amarillo correspondente ao ano de 1988, p. 149.
} 
Guiana já estava afastada. Esse conflito já não era tão intenso e outros problemas geopolíticos atraíam as atenções dos países americanos, em Granada, na Nicarágua e em El Salvador. Ainda naquele mês, 214 parlamentares brasileiros, entre deputados e senadores, enviaram carta ao presidente venezuelano expressando seu apoio às negociações pela paz na América Central conduzidas pelo Grupo de Contadora (Colômbia, México, Panamá e Venezuela). Na carta, os parlamentares explicitaram sua preocupação com o crescente envolvimento militar dos EUA na região ${ }^{116}$. De fato, a diplomacia brasileira se fez cada vez mais presente no cenário político latino-americano, ainda que somente fosse institucionalizar seu apoio ao Grupo de Contadora, com a participação no Grupo de Apoio, a partir de julho de 1985. Apenas naquele momento é que a intensificação da Guerra Fria e a solução militar protagonizada pelos EUA (conflito de baixa intensidade na Nicarágua e El Salvador e invasão de Granada) levou o Brasil a finalmente integrar o Grupo de Apoio, que depois evoluiu para formar o G-8, convergindo com a diplomacia mexicana, venezuelana e argentina. Ressalte-se, porém, que a condenação à intervenção norte-americana em Granada, ocorrida em outubro de 1983, não foi tão enfática, para que não se confundisse com uma aprovação da influência cubana sobre o governo granadino.

Jaime Lusinchi (AD), que fora ativista político, preso, torturado e exilado durante a ditadura de Pérez Jiménez, foi eleito presidente da Venezuela por maioria absoluta de votos (56\%), em dezembro de 1983. Na sua posse, em fevereiro de 1984, expressou o desejo de aproximar-se mais do Brasil, sem o qual não seria possível desenvolver uma política coerente na América Latina, segundo declarou; prometeu manter o compromisso venezuelano com a promoção da democracia no continente e reiterou a disposição de continuar promovendo o Grupo de Contadora, para evitar que intervenções militares criassem na região "um novo Vietnã ${ }^{117}$. Na cobertura feita pelo Jornal da Tarde sobre a posse, uma pergunta reveladora destacou-se na matéria, que cabe transcrever:

No que nos diz respeito, a posse do presidente Lusinchi oferece-nos a oportunidade de - entre humilhados e amargurados - formu lar uma pergunta: por que será que o Brasil, sob tantos aspectos um país mais desenvolvido e amadurecido do que a Venezuela, está ainda tão longe de igualá-la em uma autêntica prática democrática? ${ }^{118}$

\footnotetext{
116 Jornal de Brasília, 03/12/1983.

${ }_{117}$ O Globo, 06/12/1983.

118 Jornal da Tarde, 03/02/1984.
} 
O texto demonstra admiração pela política venezuelana, mas também preocupações que rond avam a política interna brasileira ainda sob ditadura.

Do lado venezuelano, persistiam ainda desconfianças quanto às pretensões de hegemonia do Brasil na América Latina, de modo geral, e na região amazônica, em particular porque ali se localiza a fronteira entre os dois países. Em conferência sobre "O desafio democrático na América Latina", realizado em Lisboa, em julho de 1984, autoridades venezuelanas ligadas ao ministério da Defesa e ao partido do governo (AD), criticaram a Escola Superior de Guerra do Brasil, ao dizer que esta seria a inspiradora dos demais regimes militares na América do Sul e deturpadora dos princípios democráticos. Segundo os venezuelanos, a doutrina da ESG estaria marcada pela concepção das Forças Armadas como mantenedoras da ordem e, por isso, manifestava desdém pela política, considerada fonte de desordem. Afirmaram também que os militares brasileiros deixavam a defesa externa a cargo dos Estados Unidos porque estavam em consonância com em harmonia com as doutrinas postuladas por Robert McNamara e Samuel Huntington. ${ }^{119}$

Pouco tempo depois da posse, em fevereiro de 1984, do presidente Jaime Lusinchi (1984-1989), o problema da dívida externa repercutia sobre as relações entre os países latinoamericanos e nas relações entre estes e os países industrializados. Lusinchi não renegava a dívida de seu país, nem ameaçava com a moratória, como tinha acontecido no México e tampouco pretendia assinar acordo com o FMI, como faria o Brasil, naquele mesmo mês. O presidente venezuelano advertia que não iria aceitar que "os credores imponham condições que sacrifiquem a economia interna do país e os trabalhadores venezuelanos". ${ }^{120}$ Essa posição do governo venezuelano visava prevenir o Fundo Monetário Internacional (FMI) de que o país não estava disposto a se submeter ao mesmo tratamento que estava sendo dispensado aos seus vizinhos da América Latina. Mesmo a Argentina, que ainda não se havia aprofundado na crise com a mesma intensidade que o México e o Brasil, já havia convidado uma equipe do Fundo para uma visita exploratória ao país. Já naquele momento, o exemplo brasileiro, que havia sido obrigado a adotar metas de superávit comercial para conseguir um novo empréstimo, servia de advertência sobre a incompatibilidade entre a manutenção de taxas satisfatórias de crescimento e as reformas preconizadas pelo FMI. O problema, no caso

\footnotetext{
${ }^{119}$ Folha de S. Paulo, 05/07/1984. A persistência da indisposição do governo venezuelano contra a ditadura militar também foi mencionada em BARBOSA, Rubens. O Brasil e a integração regional: a ALALC e a ALADI (1960-1990). In: ALBUQUERQUE, op. cit., p. 140.

${ }^{120}$ Gazeta Mercantil, 04/02/1984.
} 
brasileiro, foi que, impossibilitado de elevar satisfatoriamente as exportações no curto prazo, o governo se viu na necessidade de reprimir as importações, com prejuízo para a atividade econômica doméstica.

\subsection{FORMAÇÃO DE UMA AGENDA BILATERAL A PARTIR DA COOPERAÇÃO MULTILATERAL}

O ministro de Relações Exteriores do Brasil, Ramiro Saraiva Guerreiro, visitou a Venezuela no dia 15 de março de 1984. Naquela ocasião, foram examinados assuntos bilaterais, e foi acordado que a Comissão de Coordenação Brasil-Venezuela seria reativada (a Comissão não se reunia desde 1981). O intuito da reativação da Comissão era prosseguir com os projetos de cooperação que se desenvolviam como fruto de acordos anteriores, além de estudar formas de ampliar o intercâmbio comercial. ${ }^{121}$ Evidência da prioridade que se atribuiu aos temas comerciais foi a participação destacada do Instituto de Comércio Exterior do governo da Venezuela (ICE) na confecção da agenda da visita. O lado brasileiro indicou, como contraparte do ICE, o embaixador Roberto Abdenur, assessor econômico do ministro Saraiva Guerreiro.

Anteriormente à reunião, o embaixador brasileiro em Caracas enviou sugestões de temas para que fossem abordados, dentre os quais figuravam a elevação das tarifas para a madeira exportada de Roraima (que constituía praticamente todo o comércio fronteiriço naquele momento) e a cobertura governamental para dívidas de importadores venezuelanos com empresas brasileiras. ${ }^{122}$ Também resultou daquela reunião a decisão de se renegociarem dívidas de importadores venezuelanos de açúcar. ${ }^{123}$ Poucas semanas após a reunião, El Diario de Caracas aind a repercutia as expectativas de elevação do fluxo comercial. Segundo o jornal venezuelano, o Brasil comprava petróleo e vendia açúcar e peças industriais e automotivas,

\footnotetext{
${ }^{121}$ Libro Amarillo correspondente ao ano de 1984, p. 181.

122 Telegrama $n^{\circ}$ 252, 20/02/1984. De Afonso Arinos de Mello-Franco, Embaixador em Caracas, para o Ministério das Relações Exteriores. Secreto. Microfilmes, Telegramas recebidos, 1984.

Telegrama $n^{\circ}$ 257, 22/02/1984. De Afonso Arinos de Mello-Franco, Embaixador em Caracas, para o Ministério das Relações Exteriores. Secreto. Microfilmes, Telegramas recebidos, 1984.

${ }^{123}$ Libro Amarillo correspondente ao ano de 1984, p. 654.
} 
especialmente da General Motors, Ford e Fiat, radicadas em ambos países, caracterizando um comércio intraempresarial. O Diario considerou que a visita era uma oportunidade de aproximação comercial inédita, rompendo com um passado de mútua ignorância. ${ }^{124}$

A preocupação em diferenciar-se dos demais países latino-americanos fez com que a Venezuela não assinasse, em maio, a declaração conjunta dos países devedores latinoamericanos (Argentina, Brasil, Colômbia e México), acreditando poder conduzir melhor suas negociações individualmente. Ainda assim, decidiu-se que o país iria participar da reunião de chanceleres daquele grupo, realizada em Bogotá, entre sete e onze de junho de $1984 .{ }^{125}$ Além dos quatro protagonistas, o Equador manifestou seu apoio ao grupo, mas outros países não demonstraram interesse em participar como foi o caso do Paraguai que não tinha problemas com sua dívida externa, do Chile de Pinochet que adotava uma política econômica muito mais alinhada com o FMI e do Uruguai que preferiu acompanhar o caso com distanciamento. A Bolívia, o Peru, a República Dominicana e a Costa Rica manifestaram simpatia pela proposta do grupo, deixando em aberto a possibilidade de aderir em um momento posterior. A iniciativa dos quatro países devedores antecipava a conferência dos dez maiores países industrializados, que se reuniriam em Londres no mês de julho, e visava concertar posições para negociar o fim da elevação das taxas de juros e do protecionismo naqueles países.

A adesão do Brasil ao grupo foi considerada uma vitória do Itamaraty sobre os responsáveis pelo setor econômico do go verno de João Figueiredo, que até então conduziam o assunto da dívida externa. Alguns analistas temiam que a radicalização por parte dos devedores pudesse ser respondida, simetricamente, pelos credores, dificultando a saída da crise. Essa interpretação foi aventada também na Venezuela, ${ }^{126}$ como mostra o discurso do Minis tro das Relações Exteriores Simón Alberto Consalvi, no qual afastou a possibilidade de empenhar a diplomacia de seu país na formação de um grupo de devedores. Na reunião ministerial anual do Grupo dos 77, em outubro de 1985, afirmou:

El problema de la deuda se ha convertido en la expresión más dra mática de la situación actual. Una situación en la cual, si bien necesitamos urgentemente de la toma de acciones concertadas de cooperación, difícilmente podríamos lograr

\footnotetext{
124 Telegrama $n^{\circ}$ 513, 10/05/1984. De Afonso Arinos de Mello-Franco, Embaixador em Caracas, para o Ministério das Relações Exteriores. Ostensivo. Microfilmes, Telegramas recebidos, 1984.

${ }_{125}$ Libro Amarillo correspondente ao ano de 1985.

${ }^{126}$ Correio Braziliense, 23/05/1984.
} 
progresos significativos a través de" grandes" acciones dirigidas a la reforma estructural del sistema económico internacional. ${ }^{127}$

Apesar das resistências, a articulação de Contadora acabou sendo adotada como modelo para uma possível união dos devedores com vistas a fortalecer a posição negociadora dos países latino-americanos frente aos maiores bancos privados internacionais, seus maiores credores. De fato, o próprio Grupo de Contadora, após uma curta fase em que se dedicou exclusivamente ao tema da paz na América Central, evoluiu para uma organização internacional amplificada, em número de membros e de temas que compuseram sua pauta. Esse processo se viu reforçado a partir da Reunião Ministerial de Cartagena de Índias, realizada em junho de 1984. A Reunião congregou os ministros de Relações Exteriores e da Fazenda de Argentina, Brasil, Colômbia, México e Venezuela para discutir o problema da dívida externa e resultou na produção de um documento chamado Consenso de Cartagena, que estabeleceu os parâmetros para a reivindicação de uma solução política para a dívida, que significasse a renegociação dos termos de pagamento de juros. Segundo o relatório anual da Chancelaria venezuelana referente àquele ano, o Consenso operava como um espaço de diálogo informal e de definição de posições comuns para os países latino-americanos, fortalecendo sua posição nas negociações com os bancos credores. ${ }^{128}$

Uma diferença entre o Brasil e a Venezuela se manifestava na composição do corpo diplomático. Enquanto a diplomacia brasileira já se firmara como uma referência de profissionalismo na região, no caso da Venezuela, o preenchimento de cargos no serviço de Relações Exteriores se dava, sobretudo, por critérios políticos. Em 1984, as relações com o Brasil ainda recebiam baixa prioridade, e isso foi notado pelo embaixador brasileiro em Caracas, quando relatou a indicação de um general venezuelano que fora preterido em remanejamento do Alto Comando para o cargo de embaixador no Brasil. Na ocasião, o Presidente Lusinchi teria dito: "Estou-lhes mandando (como embaixador) um general democrata. Se não o quiserem, recusem- no". ${ }^{129}$

Em julho de 1984, o Ministro da Fazenda, Ernane Galvêas, fez um convite a seu homólogo venezuelano para visitar o Brasil com o objetivo de "desenvolver as relações

\footnotetext{
127 CONSALVI, op. cit., p. 28.

${ }^{128}$ Libro Amarillo correspondente ao ano de 1984, p. IX.

129 Telegrama $n^{\circ}$ 398, 03/04/1984. De Afonso Arinos de Mello-Franco, Embaixador em Caracas, para o Ministério das Relações Exteriores. Secreto. Microfilmes, Telegramas recebidos, 1984.
} 
bilaterais" e trabalhar "em prol da recuperação do comércio intrarregional". ${ }^{130}$ Tal visita acabou não acontecendo, e o Brasil enviou à Venezuela, em agosto, uma delegação composta por um assessor do Ministro e outros membros da Embaixada. Nessa ocasião, os problemas de pagamento do açúcar brasileiro e da restrição à importação de madeiras não haviam ainda sido solucionados, apesar das tratativas do ministro Saraiva Guerreiro no mês de março. ${ }^{131}$

Durante o ano de 1984, a imprensa venezuelana dedicou especial atenção para assuntos fronteiriços, adotando um viés bastante crítico ao Brasil. Já em fevereiro, El Universal publicou artigo em que se acusava o Brasil de apoiar secretamente a Guiana, por razões geopolíticas de acesso facilitado ao mar do Caribe, em uma disputa territorial com a Venezuela. ${ }^{132}$ Ainda sobre a fronteira, no segundo semestre daquele ano, houve grande destaque, na imprensa dos dois países, para notícias sobre o narcotráfico. Essa era uma preocupação que ascendia na região. ${ }^{133}$

Paralelamente à formação de uma agenda propriamente bilateral, os dois países continuavam cooperando em instâncias multilaterais. No dia sete de setembro de 1984, o Grupo de Contadora apresentou uma proposta para a paz às autoridades centro-americanas da Costa Rica, El Salvador, Guatemala, Honduras e Nicarágua. Os Estados Unidos e mais quatro daqueles países inicialmente aprovaram a proposta, mas voltaram atrás depois que a Nicarágua também aprovou. A estratégia dos Estados Unidos e de seus aliados era a de apenas ganhar tempo, enquanto fortaleciam suas posições militares. Um dia após as eleições norte-americanas, no dia sete de novembro, o International Herald Tribune publicou documentos secretos do governo dos Estados Unidos em que eles se congratulavam por haver bloqueado eficazmente a proposta de paz de Contadora. ${ }^{134}$ Em um gesto carregado de significado político, as autoridades nicaraguenses anteciparam as eleições que estavam programadas para acontecer em 1985, para que ocorressem apenas dois dias antes das eleições norte-americanas, no dia quatro de novembro de 1984. Os sandinistas venceram as

\footnotetext{
130 Telegrama $n^{\circ}$ 888, 29/07/1984. De Afonso Arinos de Mello-Franco, Embaixador em Caracas, para o Ministério das Relações Exteriores. Secreto. Microfilmes, Telegramas recebidos, 1984.

${ }^{131}$ Libro Amarillo correspondente ao ano de 1984, p. 654.

132 Telegrama $n^{\circ}$ 239, 17/02/1984. De Afonso Arinos de Mello-Franco, Embaixador em Caracas, para o Ministério das Relações Exteriores. Ostensivo. Microfilmes, Telegramas recebidos, 1984.

133 Telegrama $n^{\circ}$ 1390, 17/12/1984. De Afonso Arinos de Mello-Franco, Embaixador em Caracas, para o Ministério das Relações Exteriores. Ostensivo. Microfilmes, Telegramas recebidos, 1984.

Jornal do Brasil, 12/08/1984.

${ }^{134}$ MURILLO VIAÑA, op. cit., p. 141.
} 
eleições com mais de $65 \%$ dos votos. ${ }^{135} \mathrm{O}$ ano terminava, porém, em um novo impasse para a pacificação da América Central. A importância desses eventos para as relações bilaterais se revelam na coincidência de posições do Brasil e da Venezuela, que se opuseram às soluções militaristas.

No primeiro semestre de 1985, seguidas reuniões foram desmarcadas em razão do recrudescimento dos conflitos. O Congresso norte-americano recusou uma solicitação do Executivo para maiores financiamentos aos contras, mas em seguida Daniel Ortega viajou a Moscou, gerando repercussões políticas negativas. Em uma nova escalada, o Congresso dos Estados Unidos aprovou novo pedido de financiamento, concedendo US\$ 27 milhões em ajuda humanitária para os contras. Em resposta, a Nicarágua voltou atrás em sua decisão de não comprar mais armamentos. A acusação de que aquele país era uma potência militar desestabilizadora na região era um argumento recorrente entre os apoiadores da política militarista. A reunião conjunta de Contadora programada para maio de 1985 não se realizou porque a Nicarágua insistiu em que os ministros deveriam se pronunciar sobre a decisão do Congresso dos Estados Unidos. Em julho, os ministros do Grupo de Contadora propuseram um plano de seis pontos para acelerar a assinatura de um acordo de Paz, em reunião que aconteceu no Panamá. Houve propostas para que o Grupo se expandisse, aceitando a Argentina e outros países. Mas o México se opôs, alegando que a composição era eficaz. $\mathrm{O}$ México aceitava, porém, a criação de um "mecanismo de apoio". Em que pesem os contratempos, houve quem avaliasse que o Grupo de Contadora impediu que os Estados Unidos atacassem diretamente a Nicarágua, como haviam feito com Granada em 1983. ${ }^{136}$

Seguindo a proposta mexicana, os presidentes da Argentina, do Brasil e do Uruguai se uniram ao presidente peruano que tomava posse, Alan Garcia, para formar o Grupo de Apoio a Contadora. Essa decisão foi tomada em Lima, no dia 29 de julho de 1985. Para a Argentina, essa iniciativa se inseria em um contexto no qual os laços com a Europa e os Estados Unidos estavam abalados em razão da Guerra das Malvinas. Mas também se inseriam em um

\footnotetext{
${ }^{135}$ JAKOBS KIND, Mário A. América Latina: histórias de dominação e libertação. Campinas: Papirus, 1985, p. 100.

${ }^{136}$ MURILLO VIAÑA, op. cit. p. 156-159.
} 
contexto no qual a aproximação com os vizinhos latino-americanos, especialmente com o Brasil, dava a tônica de sua diplomacia. ${ }^{137}$

Tal aproximação se beneficiou de transformações no contexto político da América Latina. Desde a sua redemocratização, a Argentina também se havia convertido, ao lado da Venezuela, em um dos países promotores da democracia na região. $\mathrm{O}$ tema da democracia não estava restrito à América Central. No Brasil, o primeiro presidente civil em 21 anos, Tancredo Neves apenas tinha sido eleito, e ainda pelo voto indireto. Havendo falecido em abril, sem haver tomado posse, fora substituído por José Sarney. No Paraguai e no Chile, ainda eram dúbios os sinais de que a volta à democracia poderia acontecer em curto prazo.

Para o Brasil, continuava em jogo a mudança de suas relações com os vizinhos latinoamericanos. O período de vigência da ditadura militar havia sido marcado pela indiferença em relação a eles, quando não pela atuação aberta em favor de soluções autoritárias. Desde o último governo militar, porém, o Brasil havia iniciado um movimento de aproximação, condicionado, em parte, pelas mencionadas dificuldades em suas relações com os Estados Unidos, e pela necessidade de concertar esforços pela solução da crise da dívida externa. ${ }^{138}$ Ramiro Saraiva Guerreiro, chanceler durante o governo de João Figueiredo, já expressara o seu apoio à iniciativa de Contadora, em 1983. ${ }^{139}$ Esse apoio foi reafirmado pelo então candidato à presidência da República, Tancredo Neves, em exposição para a Comissão de Relações Exteriores da Câmara de Deputados, realizada entre os dias 28 e 29 de outubro de 1984. ${ }^{140}$ Após a formação do Grupo de Apoio, José Sarney discursou na Assembleia Geral das Nações Unidas, em setembro de 1985, reafirmando a prioridade que seu governo devotava às negociações de paz na América Central. ${ }^{141}$ Em novembro daquele ano, um encontro entre os presidentes do Brasil e da Argentina ratificou a conexão entre a cooperação desses dois países em projetos de escopo bilateral e multilateral, como era o caso de Contadora. ${ }^{142}$

\footnotetext{
137 MONIZ BANDEIRA, Luiz A. Formação do Império Americano. Rio de Janeiro: Civilização Brasileira, 2005, p. 270-271.

138 MENDIBLE ZURITA, op. cit., p. 191. OLIVEIRA, op. cit., p. 199. VAN KLAVEREN, Alberto. "Understanding Latin American Foreign Policies". In: MUÑOZ, Heraldo; TULCHIN, Joseph S. (orgs.) Latin American Nations in World Politics. Boulder, EUA: Westview Press, 1996, p. 48.

139 GUERREIRO, Ramiro S. Entrevista ao jornal O Globo. Revista Brasileira de Política Internacional. N. 101104, Ano XXVI, p. 163-171, 1983.

${ }^{140}$ NEVES, Tancredo. Exposição à Comissão de Relações Exteriores da Câmara de Deputados. Revista Brasileira de Política Internacional. N. 109-110, Ano XXVIII, p. 149-158, 1985.

141 SARNEY, José. Discurso perante a Assembleia Geral das Nações Unidas. Revista Brasileira de Política Internacional. N. 111-112, Ano XXVIII, p. 170-179, 1985.

${ }^{142}$ CAMARGO, Sônia. A integração do Cone Sul (1960-1990). In: ALBUQUERQUE, Vol. III, 2000, p. 158.
} 
No início de 1985, as vendas de petróleo venezuelano para o Brasil continuavam em declínio, o que ameaçava a expansão das exportações brasileiras para aquele país. ${ }^{143}$ Isto não impediu que a estatal brasileira Embraer vencesse a concorrência para vender à Força Aérea venezuelana 30 aviões de treinamento. A concretização do negócio, porém, apenas ocorreria no ano seguinte, com a troca de petróleo por 20 aviões, ao invés dos 30 inicialmente ne gociados.

Embora as autoridades venezuelanas pudessem ver na transição política brasileira uma oportunidade para maior aproximação com o Brasil, dada a proximidade histórica entre o partido da Ação Democrática e alguns membros do PMDB, o inesperado falecimento do presidente eleito Tancredo Neves introduziu incertezas que levaram à desaceleração dos contatos bilaterais. Jaime Lusinchi compareceu às exéquias de Tancredo Neves, em Brasília, entre os dias 22 e 24 de abril de 1985. Naquele contexto de incerteza, não estava definido o procedimento para suceder um presidente eleito, mas não empossado, e o Presidente venezuelano acabou não sustentando nenhum encontro bilateral. ${ }^{144}$ Em 21 de setembro de 1985, Sarney fez escala em Caracas a caminho de um compromisso no exterior e entrevistouse com o Presidente e com o Chanceler da Venezuela sobre relações bilaterais e conjuntura internacional. ${ }^{145}$

No dia 9 de abril de 1986, o Presidente venezuelano fez escala em Brasília em voo que o levaria para Buenos Aires. Jaime Lusinchi manteve entrevista de duas horas com José Sarney. Ao jornal $O$ Estado de S. Paulo, Lusinchi declarou: "A Venezuela dá uma importância muito grande ao reencontro do Brasil com a democracia já que nada se pode fazer na América Latina sem que o Brasil participe". ${ }^{146}$ O conteúdo da conversa foi revelado, ao menos parcialmente, por Lusinchi a jornalistas venezuelanos, já em solo argentino. Segundo reportagem do El Nacional que foi transmitida da embaixada brasileira para o ministério, o tema principal foram as negociações em torno da compra dos 20 aviões Tucanos brasileiros em troca de um incremento das exportações venezuelanas de petróleo. No entendimento dos

LIMA, Maria R. S. de. As relações do Brasil comos Estados Unidos: 1964-1990. In: ALBUQUERQUE, op. cit., p. 79.

${ }^{143}$ Telegrama $\mathrm{n}^{\circ}$ 54, 17/01/1985. De Fernando Antonio de Oliveira Santos Fontoura, min istro conselheiro na Embaixada brasileira em Caracas, para o Ministério das Relações Exteriores. Confidencial. Microfilmes, Telegramas recebidos, 1985 .

144 Carta Telegrama ${ }^{\circ}$ 1, 28/05/1985. De Afonso Arinos de Mello-Franco, Embaixador em Caracas, para o Minis tério das Relações Exteriores. Confidencial. Microfilmes, Telegramas recebidos, 1985.

${ }_{145}$ Libro Amarillo correspondente ao ano de 1985, p. 187.

${ }^{146}$ MENDIBLE ZURITA, op. cit., p. 191. 
repórteres venezuelanos, o presidente de seu país estava "eufórico e bem confiante de que se fará realidade uma frutífera vinculação política e comercial entre os dois países vizinhos". ${ }^{147}$ A negociação fechada em torno da troca de petróleo por aviões era vista como potencialmente a inauguração de uma nova era nas relações comerciais entre os países, em que a troca fosse mais frequente. Também foi retratada pelo jornal como o princípio de uma nova era nas relações políticas bilaterais. O relatório da chancelaria venezuelana para aquele ano revelou, posteriormente, que também a dívida externa e a situação centro-americana foram objeto de análise durante o encontro presidencial. ${ }^{148}$

\subsection{INTENSIFICAÇÃO DA CRISE DA DÍVIDA EXTERNA E O FRACASSO DAS TENTATIVAS DE COOPERAÇÃO}

No que se refere ao problema da dívida externa, foram se delineando nos dois países, duas maneiras distintas de interpretar a crise e elaborar estratégias. A primeira delas foi a que Paulo Nogueira Batista Jr. chamou "convencional”. No Brasil, e já durante o governo de José Sarney, esta perspectiva contava entre seus principais advogados, além do ministro Delfim Netto (no cargo até março de 1985), com Fernão Bracher (Presidente do Banco Central entre agosto de 1985 e fevereiro de 1987), Marcílio Marques Moreira (Embaixador do Brasil em Washington entre 1986 e 1991), diretores do Banco Central e assessores do presidente da República, além da imprensa, bancos, FIESP e setores exportadores, temerosos de uma confrontação com os bancos internacionais. Ernane Galvêas, quando foi Ministro da Fazenda, entre 1980 e 1985, chegou a declarar que, para os conhecedores do mercado financeiro, a dívida deveria ser saldada diretamente com os bancos credores, e não negociada entre governos. ${ }^{149}$ A proposta "convencional" era a de que o país deveria evitar atrasos no

\footnotetext{
147 Telegrama no 291, 11/04/1986. De Pau lo Henrique de Paranaguá, Embaixador em Caracas, para o Ministério das Relações Exteriores. Ostensivo. Microfilmes, Telegramas recebidos, 1986.

${ }^{148}$ Libro Amarillo correspondente ao ano de 1986, p. 156.

149 Telegrama no 728, 18/06/1984. De Afonso Arinos de Mello-Franco, Embaixador em Caracas, para o Ministério das Relações Exteriores. Ostensivo. Microfilmes, Telegramas recebidos, 1984.
} 
pagamento de juros, adotar as medid as de reforma preconizadas pelo FMI, e negociar com os bancos credores nos termos dos contratos assinados na década anterior, sem forçar maiores confrontações. Temiam os defensores dessa proposta que o fracasso em saldar os pagamentos da dívida externa gerasse retaliações comerciais ao país. Não por acaso, os setores mais ligados à economia internacional, eram os defensores mais aguerridos desta interpretação.

Essa proposta foi aplicada pelo governo brasileiro até fevereiro de 1987, quando o Brasil declarou a sua moratória. Durante aquele ano, prevaleceu o entendimento de que o país deveria interromper os pagamentos como forma de forçar os credores a aceitarem uma solução política para a crise, que implicasse o reconhecimento de que o Brasil não era o único responsável por atingir aquele nível de endividamento, uma vez que o país tinha sido prejudicado pela elevação das taxas de juros, recessão mundial, queda nos preços das exportações, situações sobre as quais não tinha qualquer controle. O Ministro da Fazenda Dilson Funaro (agosto de 1985 a abril de 1987) ficou fortemente identificado como o responsável pela sugestão da moratória; o Ministro tinha expectativa de agradar setores contrários à proposta "convencional", dentre eles, os setores nacionalistas de seu novo partido (MDB) e parcela da opinião pública. ${ }^{150}$ A moratória brasileira coincidiu com a instalação da Assembleia Constituinte, também em fevereiro daquele ano. Os debates sobre a organização econômica que foram travados no seio da Assembleia Constituinte demonstraram o predomínio de ideias nacionalistas e estatizantes entre os políticos brasileiros. ${ }^{151}$

Paralelamente às negociações com os credores, o governo brasileiro buscava abrir novos mercados para as exportações brasileiras e gerar as divisas necessárias para os pagamentos. Essa estratégia vigorou durante a presidência do general João Figueiredo e também com Sarney. As empresas multinacionais instaladas no país foram instruídas a direcionar parcelas crescentes de sua produção para as exportações, e os salários foram comprimidos como forma de aumentar a competitividade internacional dos produtos brasileiros. $^{152}$

$\mathrm{Na}$ Venezuela, a composição dos grupos de interesses na resolução da crise da dívida era bastante similar à dos grupos brasileiros. Lembramos que o ex-presidente Carlos Andrés

\footnotetext{
${ }^{150}$ BATISTA JR., op. cit., p. 41.

151 CARDOSO, Fernando H. A Arte da Política - A História que vivi. $3^{\mathrm{a}}$ Ed., Rio de Janeiro: Civilização Brasileira, 2006, p. 109.

152 VIZENTINI, op. cit., p. 146.
} 
Pérez, que permaneceu como figura bastante influente nos meios políticos de seu país, mesmo estando fora do cargo, foi uma das vozes mais críticas à proposta "convencional", bem como das exigências e atuação do FMI. Líder partidário da Ação Democrática, Andrés Pérez compareceu à reunião da Internacional Socialista em Copenhague, em maio de 1984, quando fez declarações contundentes contra os meios bancários internacionais, alegando:

A cúpula desse sistema é o FMI, que é a expressão mais acabada do totalitarismo econômico que se exerce contra nós, e que, embora não mate com bombas e com balas, mata de fome os nossos povos.

Afirmou, também, que os países em desenvolvimento e os países industrializados estavam atados com a mesma corrente, razão pela qual “(...) as moratórias podiam converterse numa cadeia que abarque todos os países, e, em lugar de moratória, passar à situação de embargo, e então sim, seria a catástrofe, onde os que mais têm a perder são os países industrializados". ${ }^{153} \mathrm{O}$ ex-presidente era um político experimentado, influente em seu partido e em permanente campanha para voltar ao poder em seu país. Suas declarações podem ser entendidas como mensagens a uma parcela considerável da opinião pública venezuelana e, neste sentido, foram eficazes.

Assim como no Brasil, os setores mais identificados com a proposta "convencional" eram aqueles cujos interesses econômicos estavam mais ligados a grupos internacionais: o setor financeiro e os empresários do comércio exterior. Em junho de 1984, uma fonte da embaixada mexicana informou ao embaixador brasileiro que a Venezuela estaria empenhada em criar obstáculos à articulação do consenso entre os países latino-americanos destinado a questionar a estratégia dos credores para gerência da dívida externa. A fonte apontou a pressão exercida pelo grupo empresarial Cisneros, o mais forte da Venezuela, como o principal responsável por essa pressão junto à diplomacia venezuelana. Esse grupo representava o establishment estadunidense na Venezuela: Chase Manhattan, Pepsi Cola, Inter-Continental Hotels, Sears, entre outros que tinham acesso "fácil e regular" ao Palácio de Miraflores, na condição de financiadores majoritários da campanha presidencial que levou Jaime Lusinchi ao poder. O Embaixador brasileiro e o seu interlocutor mexicano acreditavam que o grupo teria convencido o Presidente a recusar a adesão venezuelana a iniciativas multilaterais latino-americanas de renegociação dos termos da dívida. A adesão seria prejudicial aos interesses daqueles grupos econômicos e, portanto, pairava a ameaça de que

\footnotetext{
153 Telegrama $n^{\circ}$ 553, 15/05/1984. De Afonso Arinos de Mello-Franco, Embaixador em Caracas, para o
} Ministério das Relações Exteriores. Ostensivo. Microfilmes, Telegramas recebidos, 1984. 
deixassem de "prestar bons serviços à causa da Ação Democrática". ${ }^{154}$ Os principais jornais, tanto no Brasil, quanto na Venezuela, tendiam a defender os interesses dos setores financeiros internacionais, em detrimento das soluções políticas, que exigiriam a renegociação dos contratos. O jornal venezuelano El Universal chegou a ser identificado pelo embaixador brasileiro como "porta-voz habitual dos interesses norte-americanos, bancários e empresariais neste país". 155

A Venezuela atrasou os pagamentos de juros e da principal parte da dívida diversas vezes ao longo da década devido à indisponibilidade de recursos para o pagamento das obrigações; esses atrasos eram definidos como "moratórias". No entanto, mesmo que o governo não tivesse condições de pagar os juros no prazo estipulado, ele jamais repudiou, ou mesmo questionou, a obrigação de respeitar o cronograma e pagar o montante exigidos pelos credores com base em contratos que já não tinham condições de serem cumpridos. Além disso, o pagamento dos juros da dívida impedia que o governo respeitasse os direitos sociais dos trabalhadores e comprometia os investimentos do Estado em setores prioritários para a sociedade.

Cabe esclarecer que as chamadas "moratórias" venezuela nas não devem ser confundidas com o que o Brasil tentou fazer em 1987. Naquele momento, o governo brasileiro também alegou insuficiência de divisas para o pagamento de parcelas da dívida e declarou moratória em fevereiro. O ministro Funaro fez tentativas de forçar a renegociação das condições dos pagamentos, mas não teve sucesso porque, também no Brasil, houve pressão de grupos nacionais e internacionais que se sentiam prejudicados: o presidente Sarney se curvou a ela e em pouco menos de um ano o Brasil deu prosseguimento aos pagamentos da dívida porque os credores recusaram qualquer tipo de rene gociação. ${ }^{156}$

O governo da Venezuela se solidarizou com a moratória brasileira e Jaime Lusinchi chegou mesmo a telefonar para Sarney. Não houve intenção, contudo, de apoiar o Brasil de forma mais veemente nesse assunto, e muito menos de imitar o ges to brasileiro. ${ }^{157}$

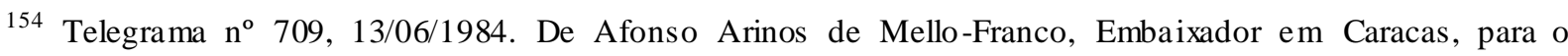
Ministério das Relações Exteriores. Secreto. Microfilmes, Telegramas recebidos, 1984.

155 Telegrama $n^{\circ}$ 588, 22/05/1984. De Afonso Arinos de Mello-Franco, Embaixador em Caracas, para o Ministério das Relações Exteriores. Ostensivo. Microfilmes, Telegramas recebidos, 1984.

${ }^{156}$ BATISTA JR., op. cit., p. 111-119.

157 Telegrama n 223, 27/02/1987. De Pau lo Henrique de Paranaguá, Embaixador em Caracas, para o Ministério das Relações Exteriores. Secreto. Microfilmes, Telegramas recebidos, 1987.
} 
A cooperação entre os dois países no que diz respeito a outros temas avançava. Em março de 1987 o Ministro brasileiro das Relações Exteriores, Roberto de Abreu Sodré, fez uma visita a Caracas. ${ }^{158}$ Nessa ocasião, aludiu aos avanços logrados na aproximação entre os dois países em virtude do aumento das visitas, afirmando: "Brasil e Venezuela vivem momentos dos mais propícios em suas relações. $\mathrm{O}$ instrumental jurídico que regula as relações entre os dois países está montado e posto em prática e o que estamos fazendo é adaptá-lo às novas necessidades". ${ }^{159}$

Foi celebrada a assinatura de um Protocolo Adicional do Acordo de Alcance Parcial $n^{\circ}$ 13, que ampliava as preferências comerciais entre os países. Os setores de petróleo, ferro, aço, mineração, papel e celulose foram apontados como sendo os mais adiantados em matéria de cooperação, principalmente pela ação das empresas estatais Petróleos de Venezuela (PDVSA), Petrobras, Corporação Venezuelana de Guayana (CVG) e Companhia Vale do Rio Doce (CVRD). A necessidade de reforçar a cooperação na região fronteiriça também foi reafirmada, e o documento saudou o encontro que o Governador do Estado Bolívar (Venezuela) e o Interventor do Território de Roraima mantiveram no mês de abril. ${ }^{160}$

O Libro Amarillo relativo àquele ano de 1987 registrou que a visita foi retribuída entre os dias $1^{\circ}$ e 6 de junho. O Ministro venezuelano foi recebido em Brasília pelo presidente José Sarney, pelo presidente do Senado Federal, Humberto Lucena, pelo Presidente da Câmara de Deputados e da Assembleia Constituinte, seu velho conhecido Ulysses Guimarães e pelo Presidente do Supremo Tribunal Federal, Rafael Mayer. Viajou também para São Paulo onde se encontrou com o governador Orestes Quércia e compareceu a almoço promovido pela

\footnotetext{
${ }^{158}$ Telegrama no 600, 07/07/1987. De Os mar Vladimir Chohfi, min istro conselheiro na Embaixada do Brasil em Caracas, para o Ministério das Relações Exteriores. Ostensivo. Microfilmes, Telegramas recebidos, 1987.

${ }_{159}$ MENDIBLE ZURITA, op. cit., p. 192.

${ }^{160}$ Libro Amarillo correspondente ao ano de 1987, p. 891-896. A Gazeta Mercantil noticiou a visita, e destacou a urgência conferida pelo chanceler venezuelano ao problema da crise econômica: "Os latino-americanos não podem esperar a chegada do colapso econômico porque temos responsabilidades sociais, de uma parte, e porque também temos direito ao bem estar e ao progresso". O jornal registrou também que a visita aconteceu após sete anos de queda no comércio bilateral, que em 1981 atingiu US\$ 1,3 bilhão (US \$ 968 em importações brasileiras de petróleo). Em 1985 o comércio havia caído para US\$ 554 milhões e em 1986 ficou em US\$ 386 milhões, dos quais apenas US\$ 57 milhões corresponderam a exportações venezuelanas ao Brasil. As exportações brasileiras centravam-se em máquinas e veículos, tratores e caminhões. Esperava-se ainda um aumento nas vendas brasileiras de produtos da "linha branca" (fogões e geladeiras), co mo resultado da diminuição dos impostos de exportação brasileiros sobre produtos manufaturados, conferida pelo Protocolo Adicional. Gazeta Mercantil, 02/06/1987.
} 
Federação das Indústrias do Estado de São Paulo (FIESP) e pela Câmara de Comércio BrasilVenezuela. ${ }^{161}$

Consideramos importante mencionar a extensa agenda de contatos de Simón Alberto Consalvi com representantes de setores políticos e econômicos do Brasil porque esses contatos refletem o aprofundamento das relações que já vinham sendo construídas há algum tempo. Também é notável que a agenda tenha incluído principalmente autoridades, mas que tenha se expandido à participação dos empresários da FIESP e da Câmara de Comércio, em uma tentativa de envolver mais ativamente setores da sociedade civil no âmbito das relações bilaterais.

A crise econômica mundial e o problema da dívida externa foram objeto do Comunicado Conjunto assinado pelos Chanceleres dos dois países. O texto se referia ao protecionismo e aos subsídios praticados pelos países industrializados como entraves para a recuperação econômica dos países "em desenvolvimento". Neste caso, o eufemismo utilizado tinha a intenção de minimizar as reivindicações, para não haver identificação com as que haviam sido feitas, anteriormente, por "militantes" da causa do "Terceiro Mundo". No Comunicado também foram expressas críticas à alta dos juros internacionais, sem, contudo, postular nenhuma proposta específica de renegociação. No que diz respeito à cooperação econômica multilateral na América Latina, os representantes dos dois países concordavam em fortalecer a sua atuação junto ao Sistema Econômico Latino-americano (SELA) e à Associação Latino-americana de Inte gração (ALADI).

Convidado pelo presidente venezuelano, José Sarney realizou visita oficial à Venezuela entre os dias 15 e 17 de outubro de 1987. Enquanto esteve na Venezuela, cumpriu extensa agenda que visava deixar evidente a aproximação das relações: recebeu as chaves da cidade de Caracas, símbolo da amizade recíproca, e pronunciou discurso em Sessão Solene do Congresso Nacional. Além disso, encontrou o ex-presidente Luis Herrera Campíns, visitou o Panteão Nacional, rendendo homenagem ao libertador Simón Bolívar, participou em reunião do SELA, onde discursou, e visitou o Complexo Hidrelétrico de Guri em companhia do Presidente Lusinchi.

${ }^{161}$ Libro Amarillo correspondente ao ano de 1987, p. 193. 
Durante as reuniões com o presidente venezuelano, foram abordados diversos temas da atualidade internacional e regional de interesse para os dois países. A Declaração Conjunta resultante dos encontros entre os dois presidentes continha 37 tópicos, dentre os quais se destacava a celebração das iniciativas de cooperação em relação ao problema da guerra civil na América Central, quando os dois países se empenharam em encontrar uma solução negociada que evitasse a intervenção dos Estados Unidos. Em um movimento contraditório com suas posições anteriores, o governo venezuelano concordou em que a Declaração aludisse á urgência de retomar, as iniciativas de cooperação dos países latino-americanos para encontrar uma saída política para o problema da crise da dívida externa. Os presidentes tomaram conhecimento dos temas tratados nas visitas bilaterais dos chanceleres naquele ano, mas estenderam o escopo da cooperação às matérias de proteção ao meio ambiente e de utilização pacífica da energia nuclear. Não foi por acaso que a cooperação no que se referia à política nuclear, tenha sido mencionada no mesmo ano em que o Brasil realizava com a Argentina uma aproximação sem precedentes nesse campo. As desconfianças recíprocas entre Brasil e Argentina sobre a utilização de tecnologia nuclear para fins energéticos e bélicos foi um dos motivos do afastamento político do Brasil em relação aos seus vizinhos latinoamericanos, que tendiam a incorporar as desconfianças dos argentinos. $\mathrm{O}$ desarme de tais suspeitas constituía, portanto, uma etapa fundamental na melhoria das relações brasileiras com os demais países da América Latina, incluindo a Venezuela.

O último artigo da Declaração Conjunta versava sobre o Programa de Ação que os dois países se propunham implementar. Tratava-se de um conjunto de metas bastante ambiciosas se comparadas com o histórico de relativa indiferença que caracterizou as relações bilaterais nas décadas seguintes. O Programa de Ação enfatizava metas de promoção comercial, fosse pela ação de empresas estatais ou pelo incentivo à realização de outros encontros com empresários, o que de fato aconteceu em São Paulo, em setembro daquele ano. Os governos se comprometiam também a incrementar a infraestrutura que unia os dois países, cooperando para o asfaltamento do trecho da estrada BR-174, que unia Boa Vista à fronteira. Brasil e Venezuela se comprometeram, ainda, a reforçar a cooperação cultural, incentivando a integração das indústrias cinematográficas e a promoção de festivais de teatro e música promovidos pelos dois países. ${ }^{162}$

${ }^{162}$ Libro Amarillo correspondente ao ano de 1987, p. 906-915. 
A Gazeta Mercantil foi o único grande jornal brasileiro a publicar matéria sobre a visita de Sarney à Venezuela e a reportagem só mencionou as dificuldades em aumentar a cooperação em matéria petrolífera. Segundo a Gazeta, o interesse manifestado pela Petrobras em investir na exploração de petróleo na Venezuela esbarrava nas leis de monopólio estatal e as vendas de petróleo venezuelano ao Brasil não conseguiam aumentar devido à concorrência dos países do Oriente Médio. ${ }^{163}$

Além da Declaração Conjunta, os dois presidentes assinaram ainda o Compromisso de Caracas, no qual afirmavam a "irreversível vontade política" que a nimava os dois governos a continuar impulsionando as relações bilaterais. Os meios para isso seriam as reuniões bilaterais regulares de altos funcionários que os mandatários se comprometiam a providenciar. De fato, a visita de Sarney a Caracas e a assinatura do documento podem ser considerados marcos do estreitamento bilateral, e por isso o Compromisso de Caracas seria reconhecido, nos anos seguintes, como o "documento mais importante" das relações entre os dois países e símbolo do sucesso dessa visita. ${ }^{164}$

O Compromisso de Caracas teve como primeiro fruto a formação da Câmara Venezuelano-Brasileira de Comércio e Indústria. $\mathrm{O}$ ato oficial aconteceu no auditório da Federação de Câmaras e Associações de Comércio e Produção da Venezuela (Fedecámaras), no dia 24 de março de 1988. O ministro conselheiro Osmar Chohfi, funcionário da embaixada brasileira presente no evento, considerou a cerimônia "muito expressiva", porque lá estiveram Carlos Andrés Pérez, já candidato à presidência, e o chanceler Germán Navas Carrillo, além de diversas autoridades e empresários. A junta diretora da Câmara estava composta de membros de primeiro escalão no ambiente de negócios venezuelanos, tais como Antonio Herrera, do Grupo Cisneros, Pedro Carmona, e Alfredo Baldó Casanova, entre outros. O Chanceler venezuelano e Andrés Pérez discursaram em apoio à iniciativa. ${ }^{165}$

Entre os dias 11 e 15 de abril de 1988, esteve presente na Venezuela uma delegação de 20 empresários da Associação Brasileira de Bens de Capital (ABDIS). Dentre os objetivos da delegação estavam: a troca de informações, o estabelecimento de contatos com os setores de

\footnotetext{
163 Gazeta Mercantil, 16/10/1987.

${ }^{164}$ Libro Amarillo correspondente ao ano de 1987, p. 915-916.

Libro Amarillo correspondente ao ano de 1988, p. 268-269 e p. 631.

Correio Braziliense, 02/02/1989.

${ }^{165}$ Telegrama n $\mathrm{n}^{\circ}$ 325, 30/03/1988. De Osmar Vladimir Chohfi, Ministro Conselheiro na Embaixada do Brasil em Caracas, para o Ministério das Relações Exteriores. Ostensivo. Microfilmes, Telegramas recebidos, 1988.
} 
bens de capital e serviços de engenharia da Venezuela, o conhecimento de projetos de investimento da Venezuela nas áreas de energia elétrica, petróleo, siderurgia, transporte ferroviário, portos e saneamento básico e, finalmente, avaliar as possibilidades de cooperação no setor ind ustrial para desenvolver projetos conjuntos, inclusive em outros mercados que não os dos dois países. ${ }^{166}$

No mês seguinte, uma delegação de empresários brasileiros do setor de pesca visitou a Venezuela. Essa iniciativa foi organizada por um órgão governamental brasileiro, a Superintendência do Desenvolvimento da Pesca (SUDEPE), e contou com o apoio, na Venezuela, do Ministério de Transportes e Comunicações. ${ }^{167}$ Dessa maneira, outras instâncias governamentais materializavam a aproximação de relações que os altos funcionários promoviam em seus encontros, discursos e tratados.

O ministro de Relações Exteriores da Venezuela, Germán Nava Carrillo, fez uma visita oficial ao Brasil, entre 16 e 17 de maio de 1988, a convite do chanceler brasileiro Roberto de Abreu Sodré. Naquele contexto, os dois ministros examinaram as matérias mais relevantes da política internacional, regional y bilateral, com especial destaque para os temas de cooperação fronteiriça e do tráfico de drogas. Concomitantemente, se realizou em Brasília a quarta Reunião da Comissão de Coordenação Venezuela-Brasil, em conformidade com o que fora estabelecido na visita do presidente Sarney a Caracas, realizada no ano anterior. ${ }^{168}$

O Grupo de Cooperação Consular se reuniu pela primeira vez entre os dias 16 e 18 de novembro daquele mesmo ano, em Puerto Ordaz, com o intuito de incentivar melhorias, em cada um dos países, de aspectos como o turismo e os negócios. A reunião também serviu para procurar soluções aos frequentes incidentes fronteiriços que envolviam índios e garimpeiros. No ano seguinte, entre os dias 11 e 12 de maio, o Grupo realizou a sua primeira Reunião Extraordinária, em Caracas e concentrou-se especificamente no tema das incursões de garimpeiros brasileiros em território venezuelano e nos danos ambientais decorrentes dessas

\footnotetext{
${ }^{166}$ Libro Amarillo correspondente ao ano de 1988, p. 633

167 Telegrama no 456, 03/05/1988. De Osmar Vladimir Chohfi, Ministro Conselheiro na Embaixada do Brasil em Caracas, para o Ministério das Relações Exteriores. Ostensivo. Microfilmes, Telegramas recebidos, 1988.

${ }^{168}$ Da visita do chanceler e da Reunião de Coordenação resultaram sete documentos bilaterais: um Acordo sobre a Zona de Não-Edificação, que restringia a construção na área fronteiriça; u m Memorando de Entendimento para a construção da estrada BR-174; um Acordo de Co-produção Cinematográfica; uma primeira Nota Reversal e Memorando para regular o transporte fronteiriço de passageiros; uma segunda Nota Reversal para a constituição de um Grupo de Cooperação Consular; uma terceira Nota Reversal para o Programa de Cooperação Técnica e a formalização de um Programa Cultural para o biênio 1988-1989. Libro Amarillo correspondente ao ano de 1988, p. 321-322.
} 
ações. A Segunda Reunião aconteceu entre os dias 10 e 11 de outubro de 1989, e resultou na aprovação de um projeto de acordo sobre circulação de pessoas e bens na área de fronteira, envolvendo inicialmente os habitantes da cidade venezuelana Santa Elena de Uairén e da capital de Roraima, Boa Vista. ${ }^{169}$ A atribuição da discussão desse tema tão delicado a uma instância especial de cooperação foi uma solução engenhosa, pois se fosse tratado através das declarações dos ministros e presidentes, seriam exploradas, de forma sensacionalista, pela imprensa gerando entraves à aproximação.

Como consequência da quarta Reunião de Coordenação Venezuela-Brasil e do Compromisso de Caracas, aconteceu no Rio de Janeiro, entre os dias 26 e 28 de julho de 1988, a Reunião sobre Cooperação Econômica Venezuela-Brasil. A delegação venezuelana foi presidida pelo Ministro das Relações Exteriores da Venezuela, e composto por funcionários do Ministério de Energia e Minas, da PDVSA, do Instituto do Comércio Exterior e do presidente e dois vice-presidentes da Câmara de Comércio e Indústria VenezuelanoBrasileira. A composição dessa delegação indica que uma aproximação inicialmente política se transformava em relação comercial. Segundo os atores envolvidos, esse procedimento estava de acordo com as exigências da época.

A Reunião versou sobre as perspectivas de ambas as economias para a complementação industrial e comercial, levando-se em conta os diferentes níveis de industrialização dos dois países. Foram definidos os seguintes setores prioritários para a complementação industrial e comercial: elétrico, eletrônico, metal-mecânico, petrolífero, de plásticos e de mineração. ${ }^{170}$ É notável que alguns dos referidos setores pressupunham uma capacidade industrial prévia que estava disponível, principalmente, no Brasil. Ainda que o documento resultante da reunião tenha explicitado a preferência oficial por ações conjuntas que envolvessem intercâmbio tecnológico e comercialização conjunta dos produtos elaborados, consideramos que a centralidade dos temas industriais foi uma vitória da diplomacia brasileira, posto que facilitava às empresas brasileiras, mais desenvolvidas que as venezuelanas, a entrada no mercado venezuelano.

Nos dias 8 e 9 de outubro de 1988, Jaime Lusinchi encontrou-se com José Sarney em visita a São Luís, no Maranhão. Ficou resolvido, naquela ocasião, que os governos iriam

\footnotetext{
${ }^{169}$ Libro Amarillo correspondente ao ano de 1989, p. 131-136.

${ }^{170}$ Libro Amarillo correspondente ao ano de 1988, p. 632.
} 
acelerar os arranjos para a assinatura de um Acordo de Integração, que poderia ser fechado ainda no primeiro semestre de 1989. Esperava-se que tal acordo reforçasse a institucionalização da cooperação entre os dois países nos setores de bens de capital e da indústria petrolífera. O referido projeto de asfaltamento de uma estrada de 220 quilômetros entre a fronteira com a Venezuela e a cidade de Boa Vista permanecia na ordem do dia e um consórcio de empresas dos dois países deveria executar a obra, estimada em US\$ 1,2 milhão. Nas conversas entre os dois presidentes, os principais assuntos abordados foram a dívida externa e o narcotráfico. ${ }^{171}$

No mês seguinte, entre os dias 9 e 11, foi realizada em Caracas uma Reunião Extraordinária da Comissão de Coordenação, em conformidade com o que fora acertado através do Compromisso de Caracas. Os assuntos abordados na Reunião se concentraram novamente em torno da cooperação econômica, especialmente nos setores de bens de capital e petróleo. Também foi objeto da Reunião a necessidade de cooperação técnica para a complementação econômica e para a construção da estrada BR-174. Por fim, foi assinado um Memorando de Entendimento Sobre Cooperação Institucional entre o Instituto de Comércio Exterior da Venezuela (ICE) e a Carteira de Comércio Exterior do Banco do Brasil (CACEX). Paralelamente a essa Reunião, o Ministro brasileiro Roberto de Abreu Sodré realizou visita de dois dias à Venezuela (10 e 11 de novembro). Em encontros com seu homólogo venezuelano, assinou um Acordo sobre Transporte Aéreo Regular, visando incentivar o desenvolvimento de voos na região fronteiriça e também de mais longo alcance, conectando os centros econômicos do Brasil com a capital venezuelana.

Após ter sido declarado vencedor nas eleições de 1988, Carlos Andrés Pérez se dedicou a um giro internacional, antes de sua cerimônia de posse realizada no dia 2 de fevereiro de 1989. Durante aquele mês de janeiro, a Embaixada brasileira em Caracas acompanhou e reportou ao Ministério das Relações Exteriores as notícias relacionadas com a sucessão presidencial, dando especial destaque para a viagem que o novo presidente fez ao México. Ali, Andrés Pérez se entrevistou com o presidente mexicano, Carlos Salinas de Gortari e se declarou "trabalhador em tempo integral" pela integração latino-americana e não "líder" dessa integração. ${ }^{172}$ Depois de sua visita ao México, Andrés Pérez veio ao Brasil, onde

\footnotetext{
171 Correio Braziliense, 02/02/1989. Libro Amarillo correspondente ao ano de 1989, p. 131.

172 Telegrama nº26, 06/01/1989. De Renato Prado Gu imarães, Embaixador do Brasil em Caracas, ao Minis tério de Relações Exteriores. Ano 1989 Telegramas e Despachos Caixa 12.
} 
conversou com o presidente José Sarney, no dia 7 de janeiro. Essa visita repercutiu na imprensa venezuelana, à qual o presidente eleito se referiu como "conversa extraordinária".

Naquela ocasião, Carlos Andrés Pérez elogiou a atuação do Grupo dos Oito, que qualificou como "revolucionário", e a política de aproximação com o Brasil conduzida pelo seu antecessor, Jaime Lusinchi. Além disso, declarou sua intenção de aprofundar aquele processo, enfatizando a cooperação na área de transportes e de manejo das bacias do Orinoco e do Amazonas.

Ainda naquele mesmo mês, o embaixador brasileiro anunciou a disposição do novo presidente venezuelano em custear a viagem de cinco jornalistas brasileiros para que fizes sem a cobertura da cerimônia de posse: Mauro Guimarães, do Jornal do Brasil, Clóvis Rossi, do Estado de S. Paulo, Newton Carlos, da Folha de S. Paulo, A. Rolemberg, do Jornal de Brasília, e um representante da TV Globo, a ser designado. ${ }^{173}$ A delegação de autoridades brasileiras foi chefiada pelo Presidente José Sarney, que esteve acompanhado pelo Ministro das Relações Exteriores, Roberto de Abreu Sodré, pelo Ministro-chefe do Gabinete Militar da Presidência da República Gal. Rubens Bayma Denys, pelos Governadores do Estado do Amazonas e do Território de Roraima, e por cinco embaixadores. ${ }^{174}$ A presença de Sarney na posse do novo presidente venezuelano era uma prova do aprofundamento das relações bilaterais, pois esta foi a primeira vez que um presidente brasileiro compareceu a esse tipo de cerimônias. $^{175}$

Fiel ao estilo grandiloquente de Carlos Andrés Pérez, sua cerimônia de posse foi a maior das que, até então, tinham ocorrido na história na América Latina; contou com a presença de 25 chefes de Estados e outras 700 autoridades e personalidades estrangeiras. Ali estiveram o recém-eleito vice-presidente dos Estados Unidos, Dan Quayle, o presidente de Cuba, Fidel Castro, o presidente da Nicarágua, Daniel Ortega, o ex-presidente norteamericano, Jimmy Carter e o primeiro-ministro espanhol Felipe Gonzalez, entre outros. O transito de Andrés Pérez entre os líderes regionais era tão grande que, no dia anterior à posse,

\footnotetext{
${ }^{173}$ Telegrama no 071, 19/01/1989. De Renato Prado Gu imarães, Embaixador do Brasil em Caracas, ao Ministério de Relações Exteriores. Ano 1989 Telegramas e Despachos Caixa 12.

${ }^{174}$ Telegrama n ${ }^{\circ}$ 071, 31/01/1989. De Ministério de Relações Exteriores à Embaixada do Brasil em Caracas. Ano 1989 Telegramas e Despachos Caixa 12.

${ }^{175}$ Folha de S. Paulo, 02/02/1989.
} 
ele se reuniu, em separado, com o Presidente Daniel Ortega e com o líder dos rebeldes antissandinistas, Alfredo Cesar. ${ }^{176}$

O presidente brasileiro declarou, ao chegar a Caracas, que as dívidas externas dos países latino-americanos eram impossíveis de pagar, e precisariam ser reduzidas pois: " $\mathrm{O}$ montante atual é certamente impagável". No dia seguinte, Sarney deveria reunir-se com outros quatro presidentes do Grupo dos Oito: Carlos Andrés Pérez, da Venezuela, Julio Maria Sanguinetti, do Uruguai, Alan García, do Peru, e Virgílio Barco, da Colômbia. Esperava-se que ratificassem o documento elaborado em dezembro pelos Ministros da Fazenda do Grupo dos Oito, no Rio, que estabeleceu mecanismos para reduzir os pagamentos da dívida, mediante concessões dos países credores. A agenda programada do presidente brasileiro incluía ainda audiências com Fidel Castro, Daniel Ortega e Dan Quayle. ${ }^{177}$ O Panamá não enviou representante por estar temporariamente suspenso do Grupo, o presidente da Argentina, Raúl Alfonsín, ficou em seu país para resolver uma crise político-militar, mas talvez a ausência mais significativa tenha sido a de Carlos Salinas de Gortari, do México, que, segundo noticiou $O$ Estado de S. Paulo: "estaria negociando um acordo em separado com os Estados Unidos e preferiu não se comprometer com uma proposta global de renegociação". ${ }^{178}$

O último encontro entre José Sarney e Carlos Andrés Pérez se realizou em Manaus, em reunião dos presidentes dos países membros do Tratado de Cooperação Amazônica, no dia 6 de maio de 1989. Nas conversas que mantiveram sobre assuntos da relação bilateral, o tema mais destacado foi a iniciativa conjunta das obras da estrada fronteiriça, BR-174. ${ }^{179}$ Esse encontro buscava revitalizar o Tratado, que apesar de ter sido firmado a mais de uma década, não havia proporcionado a cooperação esperada, principalmente porque a crise da dívida externa e a crise de segurança na América Central exigiram a concentração dos esforços da diplomacia na região. Assim mesmo, o presidente venezuelano destacou o significado da reunião para a emergência de um novo tema nas relações internacionais: a proteção do meio ambiente. A mesma interpretação prevaleceu na Declaração da Amazônia, documento resultante da reunião e assinado pelos presidentes dos países membros do Tratado. ${ }^{180}$

\footnotetext{
176 O Estado de S. Paulo, 02/02/1989.

177 Gazeta Mercantil, 03/02/1989.

178 O Estado de S. Paulo, 02/02/1989.

${ }^{179}$ Libro Amarillo correspondente ao ano de 1989, p. 135-136.

${ }^{180}$ Libro Amarillo correspondente ao ano de 1989, p. 855-860.
} 


\section{APOIO MÚTUO À DEMOCRACIA E REFORMAS (1989-1992)}

A intensificação das relações bilaterais ocorrida nos últimos anos da década de 1980 não pode impedir o agravamento da crise econômica decorrente da elevação dos pagamentos da dívida externa, e a ajuda internacional se tornou indispensável.

Frente a essa situação, aconteceram uma série de reuniões entre economistas e funcionários das principais agências financeiras internacionais e do governo dos Estados Unidos em Washington D. C., em novembro de 1989. ${ }^{181}$ Dessas reuniões surgiram recomendações para que os países do mundo capitalista, especialmente os menos desenvolvidos, adotassem a nova política que privilegiava a abertura dos mercados e o abandono da intervenção estatal na economia que havia caracterizado a política desenvolvimentista da América Latina nas décadas anteriores. Segundo as referidas instituições financeiras, as novas regras deveriam ser adotadas para solucionar os problemas que as economias nacionais vinham enfrentando desde os choques do petróleo na década de 1970, ou seja: crise fiscal, inflação intensa, déficits em conta corrente no balanço de pagamentos, crescimento econômico insuficiente, baixa produtividade de empresas nacionais superprotegidas e distorções na distribuição da renda funcional e regional.

O Consenso de Washington passou a ser aceito como a única receita capaz de solucionar a crise econômica. No entanto, a aplicação das recomendações do Consenso não se deu de maneira uniforme nos países da América Latina. O Chile, que foi pioneiro na aplicação dessas medidas, a Argentina e o México são frequentemente listados como os países que executaram fielmente as reformas neoliberais. Na Venezuela e Brasil as recomendações foram acatadas com reticências e as políticas econômicas mantiveram certas características-chave do período desenvolvimentista. ${ }^{182}$

Configurava-se, assim, uma oportunidade única e longamente esperada pelos dirigentes dos países latino-americanos para encaminhar a solução da crise econômica de seus países. Além de toda a argumentação doutrinária, o programa neoliberal contava com um

\footnotetext{
${ }^{181}$ MONIZ BANDEIRA. Conflito e integração na América do Sul - Brasil, Argentina e Estados Unidos: da Tríplice Aliança ao Mercosul (1870 - 2003). Rio de Janeiro: Revan, 2003.

SARAIVA, op. cit.

182 CERVO, op. cit., p. 216
} 
poderoso incentivo ao que os países devedores aderissem: as organizações financeiras internacionais condicionavam a concessão de novos empréstimos à aplicação das políticas recomendadas.

Nesse novo contexto, fechou-se o ciclo de questionamento à legitimidade da dívida externa e de seu manejo pelos bancos credores. Frente a essa oportunidade de negociação das dívidas e retomada dos fluxos financeiros, governos de tendências políticas diversas, aderiram ao Plano Brady e ao Consenso de Washington. A retórica de confronto, muito utilizada na década anterior, foi deixada de lado ao se constatar que, nos marcos da economia capitalista e de mercado, não haveria solução possível que não passasse pela adesão ao pacote de ajuda "oferecido" pelos detentores do capital internacional. A aplicação das reformas liberais teve que enfrentar muitos obstáculos porque feria interesses longamente estabelecidos no interior de cada país, mas apesar deles a década de 1990 acabou sendo marcada por essas reformas, que incidiram sobre os projetos de integração então em curso, incluindo as relações entre o Brasil e a Venezuela.

\subsection{AS RELAÇÕES EM UM CONTEXTO DE REFORMAS ECONÔMICAS E A ELEIÇÃO DE CARLOS ANDRÉS PÉREZ}

A prolongada crise econômica dos anos 1980 teve como efeito colateral a deterioração da confiança dos venezuelanos no sistema político. Pesquisas de opinião realizadas no período indicavam o descontentamento crescente dos venezuelanos com as instituições governamentais e partidárias do país. Antes mesmo de a crise eclodir, Vamireh Chacon escreveu, no Jornal do Brasil, que "uma parte considerável da população sabe e proclama que a revolução bolivariana está inconclus - falta completá-la socialmente, como o Libertador pregava na segunda etapa que a morte impediu de realizar". ${ }^{183}$ Tal insatisfação foi importante para que o candidato oposicionista, Jaime Lusinchi, da Ação Democrática, vencesse as eleições realizadas em dezembro de 1983.

No entanto, o novo governo, embora contasse com ampla maioria no parlamento, não conseguiu encontrar uma saída para a crise econômica porque as tentativas foram tolhidas

183 Jornal do Brasil, 20/09/1982. 
pela situação recessiva do comércio internacional e pelas obrigações do pagamento da dívida externa. ${ }^{184}$ Mesmo assim, nas eleições de 1988, o eleitorado venezuelano concedeu ao candidato do partido do governo - AD - uma vitória que a imprensa brasileira considerou "esmagadora". 185

Carlos Andrés Pérez foi eleito para seu segundo mandato (lembramos que ele havia governado o país entre 1974 e 1979). Essa vitória se deveu, fundamentalmente, ao seu prestígio pessoal. Cabe esclarecer que, ao longo do mandato de Lusinchi, o ex-presidente fez declarações críticas às políticas do governo, sobretudo em relação às negociações da dívida e à política externa. Tais declarações foram reportadas pelos embaixadores brasileiros em Caracas, desde o primeiro ano do governo de Lusinchi. ${ }^{186}$ Além desse distanciamento público em relação a um presidente impopular, Carlos Andrés Pérez tinha a seu favor a memória dos venezuelanos que viveram os tempos de bonança econômica e prestígio internacional que caracterizaram seu primeiro mandato: foi na segunda metade dos anos 1970 que os preços internacionais do petróleo e, consequentemente, a receita venezuelana de exportações, atingiram o ponto mais alto. Também fazia parte da memória de seu primeiro governo a nacionalização do petróleo e do ferro que conferiram a ele reputação de nacionalista com sentido positivo.

Tal reputação foi muito útil para sua campanha à reeleição. Andrés Perez fez muitas declarações críticas em relação aos bancos credores e às instituições financeiras internacionais, reforçando sua imagem de político nacionalista. Como mostramos no capítulo anterior, declarações dessa natureza foram feitas por ele na reunião da Internacional Socialista em 1984. Em outubro de 1987, quando foi escolhido para ser o candidato da Ação Democrática às eleições do ano seguinte, Andrés Pérez deixou bem clara sua intenção de fazer uso dessa imagem em afirmações como as que foram publicadas pela Gazeta Mercantil: "Não creio na epidemia nefasta do neoliberalismo. Não creio na política monetarista, de

\footnotetext{
${ }^{184}$ Durante o governo de Jaime Lusinchi, o preço internacional do petróleo caiu de US\$ 34 por barril para US\$ 11 por barril, com consequências severas para a economia de um país dependente dessa fonte de receitas. Gazeta Mercantil, 10/10/1987.

${ }^{185}$ Gazeta Mercantil, 06/12/1988. O Jornal da Tarde (06/12/1988) e O Estado de S. Paulo (07/12/1988) ta mbém enfatizaram a grande vantagem obtida por Carlos Andrés Pérez.

186 Especialmente em 1984, primeiro ano de mandato de Jaime Lusinchi, o embaixador brasileiro relatou seguidas iniciativas de Carlos Andrés Pérez para aglutinar, dentro do partido do governo, um grupo de oposição ao presidente. Telegrama ${ }^{\circ}$ 553, 15/05/1984. De Afonso Arinos de Mello-Franco, Embaixador em Caracas, para o Ministério das Relações Exteriores. Ostens ivo. Microfilmes, Telegramas recebidos, 1984.

Telegramas $n^{\circ} 774,26 / 06 / 1984$ e no 1112, 28/09/1984. De Afonso Arinos de Mello-Franco, Embaixador em Caracas, para o Ministério das Relações Exteriores. Secreto. Microfilmes, Telegramas recebidos, 1984.
} 
consequências tão desastrosas para os nossos países". ${ }^{187} \mathrm{Na}$ mesma reportagem, o jornal noticiou a intenção do candidato de se reunir, no Brasil, com dirigentes do Partido do Movimento Democrático Brasileiro (PMDB) e com o ministro da Fazenda, Luiz Carlos Bresser Pereira.

Ainda mais significativa foi a publicação de um artigo assinado por Carlos Andrés Pérez no número da Revista de Política Internacional referente ao último trimestre de 1988, que corresponde ao período em que foram realizadas as eleições. No artigo, intitulado $L a$ Deuda Externa: hacia uma nueva estrategia internacional, o autor ressaltou que nos seis anos transcorridos desde o estalo da crise na América Latina em 1982, a dívida total da região aumentara de US\$ 300 bilhões para US\$ 400 bilhões e isso apesar do contínuo pagamento de juros, que totalizou US\$ 150 bilhões. Ao mesmo tempo, o fluxo de recursos financeiros para a região havia "desaparecido". Considerando esse fenômeno como injusto, Andrés Pérez propôs que a solução deveria passar pela redução negociada do montante e dos juros da dívida, acompanhada de racionalização dos gastos públicos supervisionada pelas agências internacionais. ${ }^{188}$ Esse último aspecto da argumentação está longe de ser superficial porque, concedendo às agências internacionais - das quais a mais importante era o FMI - a legitimidade como supervisoras do processo de resolução da crise, o autor sinalizava com a possibilidade de que, em seu governo, pretendia entrar em acordo com aquelas instituições. Cabe notar que esse novo posicionamento estava em contradição com sua declaração anterior na qual definira o FMI como "expressão mais acabada do totalitarismo econômico".

Esta última declaração fora mal recebida pelos representantes dos bancos internacionais, dos executivos das agências financeiras e de boa parte da imprensa venezuelana e estrangeira, que estavam então bastante identificadas com os pontos de vista dos credores. O embaixador brasileiro em Caracas documentou isso em um telegrama que enviou poucos dias após a vitória eleitoral de Carlos Andrés Pérez. Segundo o embaixador, o jornal venezuelano Notipress reproduziu, a dois dias da eleição de quatro de dezembro de 1988, um artigo de Tyler Bridger, publicado no Wall Street Journal sob o título "Venezuela: débil caricatura de democracia". No entender do Embaixador, o artigo era bastante crítico

\footnotetext{
${ }^{187}$ Gazeta Mercantil, 10/10/1987.

188 ANDRÉS PÉREZ, Carlos. "La Deuda Externa: hacia una nueva estrategia internacional”. In: Revista de Política Internacional. Ano 1988, nº 12, p. 1-3.
} 
ao candidato da $\mathrm{AD}$ e refletia má vontade dos investidores internacionais para com ele. Neste sentido afirmou que havia

(...) má vontade dos meios financeiros norte-americanos para com o futuro presidente e, talvez, suas apreensões diante da possibilidade, bastante plausível, de o agora presidente eleito da Venezuela adotar posição mais rígida quanto ao pagamento da dívida externa de seu país. ${ }^{189}$

A compreensão exata do que poderia representar essa posição mais rígida dos credores era difícil para os observadores brasileiros, tanto os ligados à diplomacia quanto à imprensa, especialmente porque o presidente eleito dava declarações ambíguas, ora mais confrontadoras, ora mais conciliadoras. André Perez, ora apelava à união dos países endividados, ora enfatizava a excepcionalidade do caso venezuelano. No dia da eleição, o Jornal do Brasil publicou reportagem que sugeria comparação entre o panorama político da Venezuela e do Brasil, que realizaria eleições no ano seguinte, com boas chances para o candidato esquerdista do Partido dos Trabalhadores (PT), Luis Inácio Lula da Silva. Nesse texto o autor afirmou que:

A quase certa eleição de Carlos Andrés Pérez parece ser a primeira de uma série de sucessões presidenciais na América Latina prevista para 1989, onde a tendên cia predominante até agora é a da vitória de candidatos situados à esquerda do espectro político. ${ }^{190}$

Na mesma linha de interpretação, o Jornal da Tarde noticiou que Carlos Andrés Pérez prometia uma solução para o problema da dívida externa inspirado no presidente peruano Alan García: condicionar os pagamentos a um percentual da receita das exportações. ${ }^{191} O$ Estado de S. Paulo, do mesmo grupo empresarial do Jornal da Tarde, enfatizou a prioridade que os temas da dívida externa ocuparam no debate eleitoral, retratando o novo presidente venezuelano como um "populista-progressista, falando sempre em grandes impulsos reformistas externos e internos", ${ }^{192}$ e como "grande amigo" do político trabalhista brasileiro Leonel Brizola, outro candidato esquerdista às eleições brasileiras de $1989 .{ }^{193}$

Mas as dificuldades de interpretar o significado político da eleição de Carlos Andrés Pérez transparecem quando verificamos a existência de vozes dissonantes na cobertura da imprensa brasileira. Para o Correio Braziliense, as eleições daquele ano marcariam, não

\footnotetext{
189 Telegrama n 1237, 10/12/1988. De Renato Prado Guimarães, Embaixador em Caracas, para o Ministério das Relações Exteriores. Secreto. Microfilmes, Telegramas recebidos, 1988.

190 Jornal do Brasil, 04/12/1988.

191 Jornal da Tarde, 03/12/1988 e 05/12/1988.

192 O Estado de S. Paulo, 07/12/1988.

193 O Estado de S. Paulo, 09/12/1988.
} 
apenas a mudança de presidente, mas também uma mudança de época, deixando o EstadoProvidência de ser viável na Venezuela. Embora o candidato do Copei, Eduardo Fernandez, fosse mais identificado com as propostas neoliberais, ambos os candidatos concordavam que a solução para a crise deveria passar pela diminuição do "peso" do Estado, pela liberalização e pelo "vigoroso impulso ao setor privado". Em particular, seus assessores confessavam que essas medidas deveriam implicar maior inflação e "dramático reajuste das economias familiares". ${ }^{194}$ A Gazeta Mercantil reproduziu matéria do Business Week, que abordava o tema:

Para reforçar sua credibilidade como porta-voz financeiro da América Latina, Pérez
parece disposto a despir a imagem eleitoral populista que vinha cultivando. Nas
primeiras semanas de sua administração, afirmam seus as sessores, ele vai anunciar
medidas de austeridade que provavelmente cairão sobre os venezuelanos como uma
ducha fria. Entre elas, uma pronunciada desvalorização do Bolívar, estrito controle
das importações, e a quase duplicação das taxas de juro.

Carlos Andrés Pérez era um político experimentado e certamente tinha consciência das possibilidades de seu jogo naquelas circunstâncias. Ele pretendida contrabalançar a ira que suas declarações de campanha poderiam despertar nos credores e seus representantes, com o apoio da maioria dos eleitores que garantiriam sua vitória. A estratégia foi bem sucedida e, uma vez eleito, restava o desafio de cumprir as expectativas que criou para a solução da crise. Em todas as suas declarações como candidato ignorou que as classes políticas que dominavam a Venezuela e também o Brasil não poderiam levar a estratégia da moratória às últimas consequências sem que fossem elas mesmas também prejudicadas pela desestabilização econômica decorrente. ${ }^{196} \mathrm{O}$ rompimento definitivo com o mecanismo da dívida, caso evoluísse do discurso para a prática atingiria os interesses de setores econômicos nacionais conectados com as finanças internacionais que se colocariam contra tais medidas. $\mathrm{O}$ enfrentamento em relação aos interesses dos bancos privados e dos governos dos países desenvolvidos punha em risco a base de legitimidade de Carlos Andrés Pérez até porque os empréstimos cujos juros acabaram por estrangular a economia do país foram acertados durante o seu primeiro mandato presidencial.

\footnotetext{
${ }^{194}$ Correio Braziliense, 04/12/1988.

195 Gazeta Mercantil, 06/12/1988.

196 Naquela reunião da Internacional Socialista em 1984, citada no capítulo anterior, Andrés Pérez afirmou: "Enquanto nossos governos não se concertam para uma postulação categórica, nada faremos com lançar as culpas do que nos está sucedendo ao Fundo, aos Estados Unidos ou à Europa, porque nos inibe o temor frente a uns poderes que não pretendemos confrontar, mas perante os quais temos hoje uma força tão poderosa quanto a deles. Porque, ainda que pareça paradoxal, na nossa imensa debilidade está hoje a nossa força poderosa". Telegrama no 553, 15/05/1984. De Afonso Arinos de Mello-Franco, Embaixador em Caracas, para o Ministério das Relações Exteriores. Ostensivo. Microfilmes, Telegramas recebidos, 1984.
} 
No dia 16 de fevereiro de 1989, menos de duas semanas após a cerimônia de posse, o presidente anunciou um novo plano para resolver a crise econômica. O plano surpreendeu os observadores porque algumas das ideias do Consenso de Washington e do FMI seriam aplicadas à realidade econômica venezuelana. Anunciado por Carlos Andrés Pérez como uma estratégia para “impulsionar o processo de modernização econômica e social do país", o pacote econômico previa a liberalização do câmbio e da taxa de juros segundo as regras de mercado; diminuição da burocracia e das tarifas relativas ao comércio exterior; suspensão das contratações de funcionários públicos; aumento do salário mínimo, dos funcionários públicos e das Forças Armadas; congelamento dos preços da cesta básica e retirada de subsídios ao preço da gasolina, do telefone e da eletricidade. ${ }^{197}$ Pode-se dizer que se tratava de uma aplicação incompleta do ideário liberal, que não autorizava a elevação do salário mínimo e o congelamento de preços, mas essas eram concessões que as autoridades venezuelanas consideraram necessárias para viabilizar politicamente a "modernização" do país.

No entanto, tais concessões não eram suficientes para evitar protestos. No dia 27 de fevereiro de 1989, uma segunda-feira que ficou conhecida como o Caracazo, ou "27F", milhões de trabalhadores e trabalhadoras venezuelanas foram surpreendidos quando, no momento de embarcar no ônibus a caminho do trabalho, descobriram que o preço das passagens havia sido reajustado em $30 \%$, como consequência de outro aumento ainda mais abrup to (cerca de 100\%) sobre o preço da gasolina. ${ }^{198}$ Esses aumentos eram decorrentes do fim dos subsídios que o governo venezuelano pagava aos produtores e comerciantes e que garantira, até então, a manutenção dos preços em um patamar bastante baixo. Inconformados com o que consideraram uma traição por parte do presidente Andrés Pérez, muitos dos que apoiaram o candidato se revoltaram em diversas cidades do país, não só por se sentirem traídos, mas também por entenderem que o reajuste significaria uma pressão insustentável para o orçamento já apertado da maioria da população venezuelana. O saldo da semana trágica foram centenas de pessoas mortas, milhares de feridos e presos. Nesse ínterim, o Presidente venezuelano fez pronunciamento na televisão, pedindo calma aos venezuelanos: afirmando: "Reconhecemos que as medidas são duras, mas são o único remédio". ${ }^{199}$ Caracazo foi a primeira grande revolta na América Latina contra a aplicação da reforma

\footnotetext{
197 Telegrama no 168, 17/02/1989. De Renato Prado Gu imarães, Embaixador do Brasil em Caracas, ao Ministério de Relações Exteriores. Ano 1989 Telegramas e Despachos Caixa 12.

198 Gazeta Mercantil, 01/03/1989.

199 O Estado de S. Paulo, 01/03/1989.
} 
neoliberal e marca um divisor de águas na política venezuelana do século XX. Amado Cervo e Paulo Vizentini consideram que essa revolta poderia ter influído em toda a região nos anos 1990, catalisando a resistência às reformas. Isto não aconteceu, na interpretação dos dois autores, porque outros eventos mundiais obscureceram esse movimento venezuelano e reforçaram a visão de mundo que embasava as reformas: o fim da União Soviética, a Guerra do Golfo e a consequente elevação dos preços do petróleo. ${ }^{200} \mathrm{Na}$ Venezuela, contudo, o Caracazo jamais foi obscurecido e marcou a agonia final à política do Punto Fijo, dando início à "política das ruas", na expressão de Benício Schmidt. Segundo as estimativas desse autor, entre 1989 e 1999 houve uma média de dois protestos por dia na Venezuela. ${ }^{201}$

A crise venezuelana repercutiu bastante no Brasil através da imprensa. Em editorial veiculado no dia 3 de março, a Folha de S. Paulo enfatizou o "caráter exemplar" da tragédia venezuelana e recomendou que os candidatos à sucessão de José Sarney não caíssem na tentação de prometer qualquer coisa de irrealizável durante a campanha eleitoral, pois a confiança popular poderia ser abalada por qualquer tipo de demagogia. Também considerava exemplares os eventos na Venezuela pela demonstração dos efeitos sociais gravíssimos que a crise da dívida externa acarretava quando gerida sem levar em conta o seu caráter social e político. $^{202}$

O Estado de S. Paulo, em editorial veiculado naquele mesmo dia, adotou um tom ainda mais crítico em relação às atitudes das autoridades venezuelanas e à interpretação feita por políticos latino-americanos considerados "populistas" sobre a crise:

\begin{abstract}
É natural que o populismo na América do Sul queira ver nas mortes e nos tumultos de Caracas apenas o efeito do dedo "maligno" e das receitas do FMI, na medida em que o governo venezuelano aceitou compromissos com o Fundo. (...) A verdade, porém, exige que se procure ver como a Venezuela cavou com suas próprias mãos o caminho da crise. O governo do Sr. Jaime Lusinchi, que dirigiu o país de 1984 até o início deste ano, passou adiante uma herança pesada. Quando assumiu, Lusinchi encontrou reservas de 12 bilhões de dólares; ao sair, a caixa estava a zero. Em fevereiro de 84, o câmbio oficial cotava seis bolívares por dólar. Em janeiro passado, o câmbio negro cotava o dólar a 34. A inflação pulou, no período, de 6,3\% para $40 \%$ ao ano, com preços reprimidos cujo estampido atual é efeito da descompressão.
\end{abstract}

O editorial terminava ainda com uma recomendação a Andrés Pérez:

\footnotetext{
${ }^{200}$ CERVO, A mado L. “A política exterior da Venezuela”. In: ARAÚJO, op. cit., p. 57.

VISENTINI, Paulo G. F. "Venezuela e Brasil na Política Internacional: Um Ensaio Exploratório". In: GUIMARÃES, Samuel P. (org.). Brasil e Venezuela: esperanças e determinação na virada do século. Brasília: Instituto de Pesquisa de Relações Internacionais: Fundação Ale xandre de Gus mão, 1995, p. 29-30.

${ }^{201}$ SCHMIDT, Benício V. "A sociedade venezuelana em movimento". In: ARAÚJO, op. cit., p. 143.

202 Folha de S. Paulo, 02/03/1989.
} 
Pérez deve manter a mão firme no caminho da austeridade. É por aí, e não pela tentação de formar clubes de devedores sem resolver os problemas domésticos, que irá ganhar a confiança internacional para melhorar os termos da negociação de sua dívida e reto mar os investimentos que geram emprego e riqueza.

Diante das revoltas, o Presidente venezuelano reconheceu a legitimidade do descontentamento popular, culpando o FMI e os credores pela situação do país. Este era o posicionamento que a maioria de seus eleitores esperava, ou seja, o oposto do que era proposto pelos adeptos da modernização neoliberal, com a qual os representantes da "Grande Imprensa" brasileira se identificavam. Ao longo da semana, os confrontos de rua esmaeceram e na sexta-feira pela manhã Carlos Andrés Pérez concedeu entrevista coletiva a jornalistas estrangeiros, alertando os membros do FMI sobre a necessidade de tomar consciência de que “ou ajudam a resolver os problemas sociais dos países devedores ou haverá novas explosões, pondo em risco a democracia em todo o continente". ${ }^{203}$

Ainda durante o último ano da gestão de José Sarney, que se estendeu até a posse de Fernando Collor de Mello, no dia 15 de março de 1990, as relações bilaterais foram marcadas pelas visitas presidenciais: de Carlos Andrés Pérez ao Brasil como presidente eleito em janeiro de 1989, a de José Sarney à cerimônia de posse do presidente venezuelano em fevereiro e um encontro dos dois presidentes em Manaus, no mês de maio, por ocasião da reunião dos países membros do Tratado de Cooperação Amazônica. À parte essas visitas, também aconteceram as reuniões do Grupo de Cooperação Consular, em maio e outubro. Essas reuniões do Grupo ocorreram em decorrência de uma série de incidentes registrados na área fronteiriça que relataremos a seguir.

No dia 9 de maio, o governo venezuelano expulsou três mil garimpeiros brasileiros que se instalaram ilegalmente na Amazônia venezuelana para explorar ouro. O equipamento de mineração foi confiscado pelas autoridades venezuelanas e, em razão do episódio, foi solicitado o comparecimento de um representante consular brasileiro à Chancelaria venezuelana para uma visita de esclarecimento da situação. O incidente provocou ainda a convocação do chanceler venezuelano Enrique Tejera Paris e do ministro da Defesa, General Italo del Valle Alliegro, para que relatassem o ocorrido a uma comissão parlamentar venezuelana especialmente constituída para tratar dos problemas com os garimpeiros brasileiros: a constituição de comissão revela a importância que se atribuía a um assunto considerado de segurança nacional na Venezuela. A Embaixada da Venezuela em Brasília

${ }^{203}$ O Estado de S. Paulo, 02/03/1989. 
emitiu nota esclarecendo o episódio e reiterando a obrigação constitucional de defesa da soberania pelo Estado venezuelano e também foi anunciado que o governo recorreria à utilização de satélites para monitorar a região afetada. O incidente provocou, também, a primeira Reunião Extraordinária do Grupo de Cooperação Consular, que aconteceu nos dias imediatamente seguintes. ${ }^{204}$

Em outubro, o jornal venezuelano Diario de Caracas noticiou que, uma expedição científica venezuelana que se dirigia à nascente do Rio Orenoco, encontrou garimpeiros brasileiros na região de fronteira. Na reportagem, foram citados também testemunhos de guardas nacionais venezuelanos que atestavam a presença de brasileiros nesse local. Segundo a mesma reportagem, em outra localidade fronteiriça, distante centenas de quilômetros da primeira, muitas famílias brasileiras chegavam em grupos pequenos e essa população aumentava muito a partir da descoberta de ouro. ${ }^{205}$

Aquele ano de 1989 também foi movimentado no que diz respeito ao comércio bilateral, refletindo os esforços que foram implementados durante toda a década para gerar maior integração com o intuito de reduzir a dependência dos dois países frente aos países desenvolvidos. Em janeiro, a mineradora Corporación Venezuelana de Guayana (CVG) estabeleceu escritório no Brasil: o episódio foi reportado pelo Embaixador brasileiro como sendo matéria de especial interesse da Companhia Vale do Rio Doce - "tradicional interlocutora da CVG" -, da FIESP, da Confederação Nacional da Indústria (CNI) e da Câmara de Comércio Brasil-Venezuela, com sede em São Paulo. ${ }^{206}$ Em março, o Ministério das Relações Exteriores do Brasil solicitou que a embaixada em Caracas buscasse contato com empresários venezuelanos para atuarem como contraparte dos brasileiros que iriam à Feira Internacional da Venezuela (FIV). Os setores de interesse eram: transportes urbanos, bens de capital, siderurgia, agroindústria, recursos hídricos, telecomunicações, indústria eletroeletrônica, projetos de engenharia e outros setores s considerados pertinentes pela embaixada. O Ministério brasileiro pagou a contratação do espaço junto à Feira para que os

\footnotetext{
${ }^{204}$ Correio Braziliense, 24/05/1989.

205 Telegrama n ${ }^{\circ}$ 708, 02/11/1989. De Renato Prado Gu imarães, Embaixador do Brasil em Caracas, ao Ministério de Relações Exteriores. Ano 1989 Telegramas e Despachos Caixa 12.

${ }^{206}$ Telegrama no 104, 26/01/1989. De Renato Prado Guimarães, Embaixador do Brasil em Caracas, ao Minis tério de Relações Exteriores. Ano 1989 Telegramas e Despachos Caixa 12.
} 
empresários brasileiros pudessem participar, incrementando as exportações do país com negócios que somaram US\$ 4 milhões. ${ }^{207}$

Uma vez concluída a participação brasileira na FIV, o embaixador enviou ao Ministério o seguinte balanço:

\begin{abstract}
O evento foi de certo importante por marcar presença brasileira em momentos difíceis da Venezuela. Eventual cancelamento de nossa participação teria tido, sem dúvida, repercussões desfavoráveis a nossa imagem junto à comunidade empresarial local, de certo mu ito sensível a esse tipo de detecção após os graves acontecimentos de fevereiro e março. ${ }^{208}$
\end{abstract}

Em junho, foram divulgadas as conclusões de estudos feitos pela Agência Brasileira de Cooperação (ABC), ligada ao Itamaraty e que havia sido consultada pelo governo venezuelano, segundo os quais havia a necessidade de ampliação e modernização da frota viária do país. A Venezuela planejou então a importação de 1.500 ônibus urbanos e 500 ônibus interurbanos, parte dos quais seria adquirida no mercado brasileiro. $\mathrm{O}$ ministro dos Transportes e Comunicações da Venezuela, Gustavo Rada e o presidente da comissão presidencial, Pedro Olivares, visitaram Brasília naquele mês, onde foram recebidos pelo ministro brasileiro dos Transportes, José Reinaldo Tavares. Também foram agendadas visitas às fábricas da Mercedes-Benz, da Marcopolo e da Volvo. ${ }^{209}$

Por fim, já no ano de 1990, mas antes da mudança presidencial no Brasil, foi celebrada, em Caracas, entre os dias 16 e 19 de janeiro, uma Reunião entre o Diretor-Geral do Ministério das Relações Exteriores da Venezuela e o Secretário-Geral do Ministério das Relações Exteriores do Brasil (doravante Vice-Ministros). Naquela ocasião, o assunto em pauta eram as continuadas incursões de garimpeiros brasileiros em território venezuelano. $\mathrm{O}$ resultado da Reunião foi a concordância entre as partes para que fossem adotadas medidas preventivas de novas invasões, assim como a aceitação, pelas autoridades brasileiras, de sua responsabilidade de colaborar com o desalojamento dos garimpeiros em território venezuelano, se para tal fossem solicitados. Outro resultado do encontro foi a concordância das partes em aumentar a sinalização na região fronteiriça de Serra Parima, a oeste do estado

\footnotetext{
${ }^{207}$ Telegramas no 168, 08/03/1989 e nº 228, 29/03/1989. De Ministério de Relações Exterio res à Embaixada do Brasil em Caracas. Ano 1989 Telegramas e Despachos Caixa 12.

Telegrama no 363, 19/04/1989. De Renato Prado Guimarães, Embaixador do Brasil em Caracas, ao Ministério de Relações Exteriores. Ano 1989 Telegramas e Despachos Caixa 12.

208 Telegrama n 364, 19/04/1989. De Renato Prado Gu imarães, Embaixador do Brasil em Caracas, ao Ministério de Relações Exteriores. Ano 1989 Telegramas e Despachos Caixa 12.

${ }^{209}$ Gazeta Mercantil, 05/06/1989.
} 
brasileiro de Roraima, o envio de uma missão de técnicos brasileiros às zonas de desmatamento para que avaliassem os danos realizados e a assistência que o Brasil deveria fornecer para recuperar a zona, que envolveria a troca de informações, o monitoramento por satélites da região e o compartilhamento de experiências nas áreas de engenharia e construção que fossem adequadas à região. ${ }^{210}$

O legado da gestão Sarney, no que diz respeito às relações bilaterais, foi de aumento de confiança e extensão dos encontros para além das equipes presidenciais. Desde os anos finais da década anterior, os contatos empresariais eram mais frequentes, assim como as visitas de outras autoridades de governo. No espaço de duas semanas, entre os dias 13 e 22 de janeiro de 1990, os governadores de dois dos maiores estados brasileiros visitaram a Venezuela, separadamente. Entre os dias 13 e 16, foi o governador de São Paulo Orestes Quércia e, na semana seguinte, foi o governador do Rio de Janeiro, Moreira Franco. ${ }^{211}$ Essas visitas não tiveram repercussão comercial, mas política porque os dois governadores eram membros do PMDB, cujas lideranças eram muito afinadas com as do partido venezuelano $\mathrm{AD}$, do então presidente Andrés Pérez.

\subsubsection{A eleição de Fernando Collor de Mello}

A eleição presidencial brasileira de 1989 foi a primeira eleição direta desde 1960 e significou um momento de especial interesse na história política brasileira, gerando expectativas nos observadores internacionais, inclusive venezuelanos. Ao todo, 22 candidatos concorreram ao pleito. Naquele momento, se destacava a baixa popularidade do presidente Sarney, que assumira na condição de vice-presidente devido ao falecimento do presidente Tancredo Neves, eleito, de forma indireta, em 1985. Além disso, Sarney construíra sua carreira política apoiando e se beneficiando da ditadura: esse déficit de legitimidade era agravado pelo insucesso do governo na condução da crise econômica e da dívida externa.

O Plano Cruzado posto em prática nesse novo governo gerou muita expectativa no momento de seu lançamento, em 1986, mas resultou em fracasso quanto a sua meta de

\footnotetext{
${ }^{210}$ Libro Amarillo correspondente ao ano de 1990, p. 176.

${ }^{211}$ Libro Amarillo correspondente ao ano de 1990, p. 103-104.
} 
estabilizar a economia e conter a escalada inflacionária. A moratória da dívida externa, nova tentativa governamental de solucionar os problemas econômicos, também fracassou por falta de apoio interno e devido a resistências internacionais.

Nesse contexto, a iniciativa diplomática de aproximação com os vizinhos da região, com especial destaque para os acordos de comércio com a Argentina (1986) e as visitas do presidente à Venezuela (1987 e 1989), representaram uma das poucas ações bem sucedidas do governo Sarney. Esta situação de isolamento político levou a que todos os candidatos à primeira eleição direta se declarassem, em maior ou menor grau, em oposição a ele. ${ }^{212}$

Havia muita expectativa quanto ao desempenho dos candidatos da esquerda, em razão do bom desempenho que os seus partidos demonstraram nas eleições municipais do ano anterior. Especialmente o Partido Democrático Trabalhista (PDT) e o Partido dos Trabalhadores (PT) foram vitoriosos em cerca de $25 \%$ dos quatro mil municípios brasileiros, projetando boas perspectivas para a candidatura de seus líderes, respectivamente Leonel Brizola e Luis Inácio Lula da Silva. Os principais jornais brasileiros consideravam que a eventual vitória de qualquer um desses dois candidatos na eleição de 1989 representava um risco ao que consideravam a boa gestão da dívida externa: o corte de gastos e programas sociais, além de privatização de empresas do Estado, para pagamento integral e pontual de juros. De fato, a suspensão do pagamento da dívida externa fazia parte do programa do PT em $1989 .^{213}$

Na cobertura da imprensa brasileira sobre as relações entre o Brasil e a Venezuela, a desconfiança frente aos candidatos da esquerda se manifestou através da comparação, pelos jornais $O$ Estado de S. Paulo e Jornal do Brasil, entre Carlos Andrés Pérez, com seu discurso crítico ao FMI, e Leonel Brizola. Nos dias que se seguiram à eleição do novo presidente venezuelano, O Estado de $S$. Paulo lembrou que ele havia declarado ser "grande amigo" de Leonel Brizola. ${ }^{214}$ Poucos meses depois, o Jornal do Brasil destacou esse fato, através de uma reportagem na qual se referia a Andrés Pérez como "democrata com tendências esquerd istas" e o "mais populista dos políticos venezuelanos". 215

\footnotetext{
${ }^{212}$ LAMOUNIER, Bolívar. "Antecedentes, riscos e possibilidades do governo Collor". In: LAMOUNIER, Bolívar (org.). De Geisel a Collor: o balanço da transição. São Paulo: Ed. Su maré, 1990, p. 23.

${ }^{213}$ SECCO, Lincoln. História do PT. Cotia, SP: Ateliê Ed itorial, 2011, p. 133.

${ }^{214}$ O Estado de S. Paulo, 09/12/1988.

${ }^{215}$ Jornal do Brasil, 01/03/1989.
} 
No intervalo de um ano, entre a eleição presidencial venezuelana ocorrida em dezembro de 1988 e a eleição brasileira, cujo segundo turno aconteceu em dezembro de 1989, a cobertura que os principais jornais brasileiros fizeram sobre a crise política do primeiro ano de Carlos Andrés Pérez (decorrente, em grande parte, da contradição entre seu discurso crítico e adesão ao neoliberalismo, na prática) foi marcada pela critica ao seu discurso contrário ao neoliberalismo, visto como "aventura populista". Enquanto os dois governos tentavam apresentar as relações bilaterais como coincidências e positivas, os jornais brasileiros criticavam o populismo de Carlos Andrés Pérez e defendiam a modernização.

Durante o processo das eleições no Brasil, emergiu a figura de Fernando Collor de Mello como sendo o candidato mais bem identificado com a modernidade econômica e política que esses veículos de imprensa, juntamente com a influente $T V$ Globo, defendiam ${ }^{216}$ Collor era o governador do pequeno estado de Alagoas e pouco conhecido do eleitorado brasileiro. Sua juventude (tinha 40 anos quando foi eleito), seu estilo reconhecidamente arrojado e impetuoso de se comunicar contribuíram para a composição da imagem de um candidato modernizador e, portanto, capaz de mudar o país. Esperava-se que ele fosse capaz de derrotar, nas eleições, os candidatos da esquerda, identificados como populistas - palavra sempre utilizada como sinônimo de "demagogos" - e vinculados com o que era retratado como anacronismo socialista, comparado sempre com a desagregação então em curso do mundo socialista.

Collor, diferentemente de Brizola e Lula, era considerado moderno, no sentido de que estava afinado com o discurso que emanava de Washington, segundo o qual não haveria futuro em um possível enfrentamento entre devedores e credores do sistema econômico internacional. Segundo essa perspectiva, cabia aos devedores ajustar suas economias ao pagamento dos valores exigidos, mediante a diminuição dos gastos do Estado. O governador de Alagoas conquistou fama nacional como "caçador de marajás" por força de sua ação enérgica na diminuição do quadro de funcionários públicos em seu estado. ${ }^{217}$ Uma vez eleito, comemorou sua vitória com uma frase marcante: "o Brasil não trocou de presidente, trocou de geração".218

\footnotetext{
${ }^{216}$ LAMOUNIER, op. cit., p. 29.

217 CA RNEIRO, Maria C. R. O Governo Collor-1990-1994. São Paulo: Editora Três, 1999, p. 42.

218 Jornal de Brasília, 10/03/1990. Referência ao discurso modernizador da campanha de Fernando Collor pode ser encontrada em CERVO, Amado L. "Relações Internacionais do Brasill. In: CERVO, A mado L. (org.) $O$ Desafio Internacional: a política exterior do Brasil de 1930 a nossos dias. Brasília: Ed. UnB, 1994, p. 52.
} 


\subsection{AS RELAÇÕES BILATERAIS APÓS AS ELEIÇÕES VENEZUELANA E BRASILEIRA}

Cabem, portanto, algumas comparações entre a situação venezuelana e a brasileira dando ênfase ao significado político da eleição de Carlos Andrés Pérez e de Fernando Collor de Mello.

A principal semelhança entre os dois processos reside no contexto de crise econômica acompanhada de crescente insatisfação política nos dois países, mas não só neles porque a crise se estendeu por toda a região latino-americana. Carlos Andrés Pérez tinha grande popularidade ancorada na memória de sua primeira gestão, quando a conjuntura econômica era mais favorável ao país. Durante a campanha, foi identificado como o candidato da esquerda em seu país, crítico das instituições financeiras internacionais e oposto à candidatura abertamente neoliberal de Eduardo Fernández, do Copei.

Collor, ao contrário, era pouco conhecido nacionalmente, mas essa característica pesou a seu favor porque permitiu que se apresentasse como alguém pouco comprometido com a desacreditada classe política brasileira, vista como responsável pela derrocada econômica. Ele construiu sua candidatura em oposição ao candidato da esquerda brasileira, Luís Inácio Lula da Silva, do PT. Uma vez eleitos, os dois presidentes aderiram às reformas neoliberais preconizadas pelo Consenso de Washington. No caso do presidente brasileiro, as reformas estavam de acordo com suas promessas de campanha e em conformidade com a expectativa que sua candidatura gerou. No caso do presidente venezuelano, sua atuação contrastou fortemente com as expectativas da campanha: além de não conseguir solucionar a crise econômica, permitiu que o ambiente político se deteriorasse.

Pouco antes da posse do novo presidente brasileiro, Carlos Andrés Pérez manifestou sua disposição de continuar o processo de aproximação dos dois países e, para reforçar a importância dessa relação bilateral, enumerou os diversos temas de interesse comum e insistiu na possibilidade de união entre os governantes latino-americanos para pressionar a ne gociação da dívida externa e controle dos preços dos produtos de exportação. Neste sentido afirmou:

As relações entre Venezuela e Brasil são mais do que diplomáticas. Temos o Pacto Amazônico, o Grupo dos Oito (Contadora). A dívida é um problema comum e só será realmente resolvida, como principal problema da América Latina, com nossos países unidos, aliados, juntos, não para fazermos imposições, mas para defendermos 
nossas posições. Juntos, podemos impedir a imposição unilateral de preços. Não poderemos pagar a dívida se não resolvermos o problema da balança de pagamentos, defendendo os preços de nossos produtos. Tudo isso exige uma ação comum na América Latina. ${ }^{219}$

Apesar dessa alegada disposição em rever os termos das negociações, a imprensa brasileira destacou o fato de que a Venezuela estava prestes a entrar em acordo com os credores para redução temporária dos pagamentos dos juros da dívida, medida que viria a se somar aos termos já aceitos do Plano Brady. Os credores resistiam em conceder tratamento especial à Venezuela, alegando que as receitas do petróleo lhe garantiam capacidade de pagamento, mas o presidente venezuelano insistia em receber maior alívio no tratamento da dívida "para implementar as políticas de estabilização e reforma econômica". O exemplo do México, que conseguira o melhor acordo (35\% de redução sobre principal e juros), era sempre invocado como forma de ressaltar que o principal benefício da renegociação era a restauração da credibilidade, que permitia queda dos juros e retorno de investidores. ${ }^{220}$ De fato, o acordo foi realizado naquele mesmo mês, com o aval do FMI.

Em uma série de colunas publicadas no Jornal de Brasília, Sebastião Nery verbalizou o apoio que outros jornais brasileiros também concediam às negociações da dívida que fossem realizadas nos marcos do neoliberalismo e do FMI. Segundo o articulista, a grande lição a ser tirada do século $\mathrm{XX}$ era que o Estado era incompetente para gerir o desenvolvimento econômico e essa lição já estaria sendo aprendida pelos povos latino-americanos, que rechaçavam políticos demagogos e autoritários, como Daniel Ortega e Lula, derrotados nas eleições presidenciais em seus países. ${ }^{221} \mathrm{Na}$ Folha de S. Paulo também foi enfatizado o caráter exemplar da renegociação venezuelana, em matéria publicada no dia 29 de março na qual se lê: "As autoridades brasileiras deverão estar atentas ao desenrolar desse processo. Pois, em breve, protagonizarão uma renegociação que, pela dimensão do débito brasileiro, imporá um teste bem mais difícil aos pressupostos do Plano Brady". ${ }^{222}$

Entre os dias 15 e 16 de março, o presidente venezuelano visitou Brasília para participar da cerimônia de posse de Fernando Collor de Mello, retribuindo assim a visita de José Sarney a Caracas, no ano anterior. Carlos Andrés Pérez estava acompanhado de seu

\footnotetext{
219 Jornal de Brasília, 08/03/1990.

${ }^{220}$ O Estado de S. Paulo, 13/03/1990.

221 Jornal de Brasília, 13/03/1990.

${ }^{222}$ Folha de S. Paulo, 29/03/1990.
} 
chanceler, como de praxe nessas ocasiões e fez convite a Collor de Mello para que se encontrassem na fronteira entre os dois países ainda naquele ano. ${ }^{223}$

A posse do novo presidente brasileiro foi notícia destacada nos diários caraquenhos $E l$ Universal (Guerra a muerte a la inflación), El Nacional (Collor promete lucha contra la corrupción) e El Diario de Caracas (Collor auspiciará unidad latino-americana). A cobertura que esses jornais deram ao evento foi marcada pelo tom positivo. Foi destacada a juventude do presidente, o seu comprometimento com o projeto neoliberal de reforma econômica que descartava a confrontação como estratégia de gestão da dívida externa. Os jornais davam destaque a suas promessas de "reconstrução do país" e de promoção da justiça social e com a priorização das relações com a América Latina. Especialmente o Diario de Caracas enfatizou este último aspecto, citando o discurso proferido por Collor no qual ele declarou: "Para o Brasil o grande espaço imediato será a América Latina, com seu epicentro econômico no Cone Sul". 224

\subsubsection{As trocas comerciais nesse novo contexto}

Na gestão dos governantes André Perez e Collor de Mello, as relações de comércio entre os dois países atravessavam dificuldades. A crise econômica causara a diminuição da capacidade do governo brasileiro para apoiar a Engesa, empresa brasileira produtora de material bélico e fornecedora para diversos países estrangeiros, inclusive a Venezuela. Desde 1987, a Engesa tinha uma encomenda para fabricar veículos blindados para o exército venezuelano. O prazo final para a entrega (maio de 1990) se aproximava e a empresa não tinha condições de cumprir com o acordo. Por um lado, a Engesa pressionava o governo brasileiro para que atuasse junto ao governo venezuelano com vista a obter extensão do prazo inicialmente acordado; por outro, o exército venezuelano exigia a entrega dos veículos. Essas comunicações eram feitas através da embaixada brasileira em Caracas e o embaixador considerou desastroso o não cumprimento do acordo pela empresa brasileira porque sua imagem ficaria afetada num momento de fragilidade financeira, podendo até mesmo afastar

\footnotetext{
223 Libro Amarillo correspondente ao ano de 1990, p. 99.

${ }^{224}$ Telegrama no 199, 17/03/1990. De Renato Prado Guimarães, Embaixador do Brasil em Caracas, ao Ministério de Relações Exteriores. Ano 1990 Telegramas Caixa 4.
} 
outros potenciais clientes. Cabe lembrar que outra empresa brasileira do setor da indústria bélica, a Diana Trading, já enfrentava resistências no mercado venezuelano em razão da crise com a Engesa. ${ }^{225}$

Ainda em março, as autoridades venezuelanas anunciaram um amplo acordo com os bancos credores, pelo qual os pagamentos da dívida externa teriam os valores e prazos renegociados. Os bancos também se comprometeram a restabelecer os empréstimos ao país. Tal acordo só foi possível em razão do aceite por parte do governo venezuelano dos termos do Consenso de Washington e do Plano Brady. Mas, em decorrência desse acordo, as disputas na Venezuela se intensificaram entre os que advogavam uma solução de união dos países latinoamericanos para confrontar os credores da dívida e os defensores da adesão dos governos ao neoliberalismo.

Nesse ínterim, a crise econômica venezuelana começava a ser superada e, nos anos seguintes, o crescimento econômico foi retomado. No entanto, a crise política que se instalou durante esse processo de recuperação se mostrou bem mais difícil de solucionar. O governo passou a contar com o apoio dos adeptos das reformas neoliberais, mas as ruas foram tomadas, durante toda a década, por protestos diários contra o desmantelamento do Estado de Bem-Estar venezuelano.

O embaixador brasileiro referiu-se às reações dos venezuelanos ao acordo do governo com os bancos estrangeiros, comentando que ele foi apoiado pelo empresariado local, pelos principais partidos políticos e agremiações sindicais ligadas ao partido do governo, AD. Comentou, também, que a boa vontade do governo dos Estados Unidos, que se dispôs a emprestar US\$ 400 milhões para pagamento de juros de curto prazo, também fora fundamental para a concretização do acordo. ${ }^{226}$

No que se refere às relações bilaterais, cabe mencionar que, em janeiro, houve um encontro entre os Vice-Ministros que resultou numa reunião ocorrida em Caracas no dia 8 de maio, entre a Agência Brasileira de Cooperação (ABC) e o Ministério de Relações Ex teriores da Venezuela. Nessa reunião, as delegações definiram os temas que seriam objeto de um

\footnotetext{
225 Telegramas $n^{\circ} 113,14 / 02 / 1990 ; n^{\circ} 231,02 / 04 / 1990 ; n^{\circ} 240,07 / 04 / 1990 ; n^{\circ} 350,30 / 05 / 1990$. De Renato Prado Guimarães, Embaixador do Brasil em Caracas, ao Ministério de Relações Exteriores. Ano 1990 Telegramas recebidos. Secreto. Caixa 261.

${ }^{226}$ Telegramas no 213, 21/03/1990 e n 217, 22/03/1990. De Renato Prado Guimarães, Embaixador do Brasil em Caracas, ao Ministério de Relações Exteriores. Ano 1990 Telegramas Caixa 4.
} 
Programa de Cooperação Técnica para a Área Fronteiriça: imagens de satélite, cartografia e meio ambiente. A cooperação exigia que fossem enviados ao Brasil técnicos venezuelanos, para que recebessem treinamento em cartografia e imagens de satélites.

Ainda em maio, entre os dias 18 e 21, uma delegação de quatro deputados brasileiros, entre os quais estava a deputada Marcia Kubitschek (Presidente da Comissão de Política Externa da Câmara de Deputados), visitou a Venezuela a convite do chanceler Figueredo Planchart. Além de encontrar-se com o Ministro, a delegação parlamentar visitou lugares de interesse turístico e industrial nos arredores de Ciudad Guayana e entrevistou-se com o Presidente do Congresso Nacional venezuelano, David Morales Bello. ${ }^{227}$

A região de fronteira continuava problemática. Desde o começo do ano, a embaixada brasileira passou a intermediar as comunicações entre os dois governos para coordenar ações de demarcação fronteiriça e combate ao garimpo ilegal. Já em janeiro, as forças armadas venezuelanas manifestaram interesse em construir uma base militar próxima à fronteira, na serra de Parima, em uma localização conhecida como "Parima B". Ali, a Força Aérea Brasileira já começara a construção de uma base, que foi abandonada após a constatação de que o lugar ficava, na realidade, em território venezuelano. Esse episódio é revelador sobre o pouco controle efetivo que as autoridades dos dois países exerciam sobre a região de fronteira. Quando o governo venezuelano declarou a intenção de construir a base, o Brasil já possuía uma base militar nas proximidades, em seu próprio território, com objetivo declarado de vigiar os movimentos dos garimpeiros. Em março, a Guarda Nacional venezuelana realizou incursão numa pista clandestina de pouso, que estava construída exatamente na fronteira, abarcando território dos dois países simultaneamente. Como resultado da ação, foram detidos 11 cidadãos brasileiros, em território brasileiro. Além das atividades de garimpo, a ação de narcotraficantes começava a preocupar as autoridades. ${ }^{228}$

O Embaixador brasileiro passou as informações do que estava ocorrendo na região ao Ministério das Relações Exteriores antes da visita do chanceler venezuelano, Reinaldo Figueredo, faria ao chanceler brasileiro Francisco Rezek entre os dias 19 e 21 de junho. Os temas a serem tratados, por indicação da chancelaria venezuelana, versavam sobre as

\footnotetext{
${ }^{227}$ Libro Amarillo correspondente ao ano de 1990, p. 176.

228 Telegramas $n^{\circ} 31,15 / 01 / 1990 ; n^{\circ} 167,08 / 03 / 1990 ; n^{\circ} 179,10 / 03 / 1990$. De Renato Prado Guimarães, Embaixador do Brasil em Caracas, ao Ministério de Relações Exteriores. Ano 1990 Telegramas recebidos. Secreto. Caixa 261.
} 
atividades dos garimpeiros, a proteção ambiental, o narcotráfico, as relações com Cuba, a integração continental e a preocupante guinada da diplomacia mexicana em relação aos países do "Norte".

A respeito do narcotráfico, o chanceler venezuelano viajara repentinamente a Washington no começo daquele ano, com o objetivo declarado de proferir discurso na OEA sobre o Panamá e América Central, mas o real objetivo era um encontro sigiloso com autoridades estadunidenses para debater matéria da rede de televisão $\mathrm{ABC}$ veiculada em horário nobre na qual a Venezuela era retratada como "nova Meca dos narcotraficantes" e se referia ao governo como "cúmplice interessado" ou "protagonista indiferente". O chanceler não aceitou a desculpa oficial dos norte-americanos, segundo a qual a rede de televisão privada não poderia ser censurada pelo governo estadunidense em um contexto de liberdade de imprensa. Alegou que a rede americana utilizou fotos tiradas pelos serviços de informação venezuelanos e outros filmes de acesso restrito, que somente haviam sido concedidos à agência estadunidense de combate às drogas com a finalidade de colaboração policial. $\mathrm{O}$ referido programa chegava a retratar o chanceler venezuelano dizendo que não se deviam fazer escândalos sobre o assunto, descontextualizando sua afirmação feita em contexto muito diferente. Como consequência desse episódio, a Venezuela não concedeu agreement para o embaixador designado pelos EUA, porque esperava retratação oficial da ABC. Nesse contexto, os EUA ficaram 11 meses sem embaixador em Caracas, ou seja, desde julho de 1989.

Pelo relato do embaixador brasileiro, o chanceler venezuelano estava realmente irritado com a nova postura mexicana, que desqualificava, a seu ver, a cooperação no âmbito do Grupo dos Três. Estava preocupado com a capacidade de atração dos EUA frente aos demais países latino-americanos, "risco ao qual não seria a Venezuela invulnerável". Apenas o Brasil estava isento desse risco, na visão do chanceler venezuelano, porque suas dimensões eram grandes demais para servir de satélite. Reinaldo Figueredo queria que o Brasil liderasse a inte gração continental, especialmente utilizando seu acervo de ciência e tecnologia. ${ }^{229}$

Como resultado da reunião ministerial de junho, foram assinados diversos documentos que buscavam institucionalizar o interesse crescente de ambos os lados da fronteira. Além do

\footnotetext{
${ }^{229}$ Telegrama no 389, 14/06/1990. De Renato Prado Gu imarães, Embaixador do Brasil em Caracas, ao Ministério de Relações Exteriores. Ano 1990 Telegramas recebidos. Secreto. Caixa 261.
} 
Acordo sobre Circulação de Turistas, resultou também um Memorando de Entendimento para formação de um Mecanismo Político de Consulta e foram trocadas Notas Reversas para a criação de um Grupo de Trabalho de Cooperação Técnica. A agenda do ministro venezuelano contemplou ainda encontros com os governadores dos estados brasileiros do Amazonas, Roraima, São Paulo e Paraná, além de reuniões empresariais em São Paulo e Manaus, onde se encerrava a visita com o Encontro de Empresários Venezuelanos e Brasileiros. ${ }^{230}$

De fato, os temores de Reinaldo Figueredo a respeito da capacidade de atração dos Estados Unidos junto aos países latino-americanos pareciam se confirmar quando, no dia 27 de junho, o presidente George Bush anunciou a Iniciativa para as Américas. Ela compreendia três áreas temáticas, assim agrupadas por Lia Pereira e Mario Presser: comércio exterior, dívida externa e investimento. Tais assuntos eram prioritários para os governos latinoamericanos, que não puderam resolvê-los através do incremento da cooperação regional. No que se refere ao comércio exterior, a proposta dos Estados Unidos era a eliminação das barreiras comerciais na América, em consonância com o Consenso de Washington. Para os países que aceitassem essa estratégia de integração comercial, além de aderir ao que o governo estadunidense, o FMI e o Banco Mundial entendiam como boas práticas de manejo econômico (também expressas no Consenso) foi oferecida a diminuição da dívida bilateral oficial, ou seja, daquelas dívidas cujo credor fosse o governo dos EUA. Por fim, se ofereceu também como incentivo ao Acordo, a inauguração de um novo programa de empréstimos do Banco Interamericano de Desenvolvimento (BID), além da criação de um fundo multilateral de investimentos para o qual os Estados Unidos contribuiriam com US\$ 100 milhões anuais. $^{231}$ Tal oferta representava uma oportunidade de alívio da crise econômica para os países latino-americanos.

Não era o que os defensores de uma atitude mais coordenada e combativa frente ao problema da dívida pensavam que seria possível obter, uma vez que excluía qualquer concessão da parte dos bancos multinacionais, que eram os maiores credores. Mas o fato era que a coordenação de posições entre os países latino-americanos não se concretizou e em 1990 já era uma possibilidade raramente evocada. Não fora possível construir entre os

\footnotetext{
${ }^{230}$ Libro Amarillo correspondente ao ano de 1990, p. 177.

231 PEREIRA, Lia V.; PRESSER, Mario F. "A Iniciativa Para as Américas, o NAFTA e o Mercosul”. In: BATTA GLINI, Elena et al. Mercosul - Integração na América Latina e Relações com a Comunidade Europeia. São Paulo: Inca, 1993.
} 
governos da região a confiança necessária para articular uma iniciativa tão ousada que consistia em confronto com os polos de poder do capitalismo mundial: bancos e governos dos países desenvolvidos. E, mesmo que houvesse tal confiança entre os governos latinoamericanos, a maioria deles, em qualquer momento da década de 1980, era sustentada pelos principais grupos econômicos de seus países, como revelou o embaixador brasileiro com referência ao governo venezuelano, em telegrama citado no capítulo anterior. Referia-se às elites econômicas latino-americanas que tinham vinculação preferencial com o capitalismo internacional. Confrontar os credores, portanto, seria voltar-se justamente contra o elo estrangeiro de um sistema de hegemonia política do qual aqueles mesmos governos faziam parte.

Mais do que isso, a forma que tomou a posição dos credores, de fazerem valer os contratos de empréstimo que os governos latino-americanos firmaram na década de 1970 e que previam a flutuação dos juros, era perfeitamente compatível com os princípios do capitalismo: respeito à propriedade privada (o capital emprestado pelos bancos) e aos contratos firmados livremente.

Pelo exposto, concluímos que os apologistas da reforma neoliberal tinham razão quando disseram não haver outra saída. Apenas podemos acrescentar: não havia outra saída ao alcance dos países endividados dentro do respeito às regras do capitalismo. As dívidas poderiam ser perdoadas, mesmo que parcialmente, pelos credores. Mas isto já seria uma atitude contrária à própria razão de existência daquelas instituições: buscar os melhores retornos possíveis aos seus investimentos. Por isso, era uma solução que não estava ao alcance dos meios de que dispunham os políticos da América Latina. Esse era o contexto de impotência dos governos da região quando os Estados Unidos ofereceram a Iniciativa para as Américas, que era tímida, por não incluir nenhum esforço da parte dos bancos credores, mas era uma oportunidade real de abatimento de parte da dívida e de retomada dos fluxos de financiamento, tão necessários à recuperação do capitalismo latino-americano. Essa também foi a interpretação da imprensa e dos meios empresariais e políticos da Venezuela, que receberam positivamente o anúncio da Iniciativa, tal como foi reportado pelo embaixador brasileiro. $^{232}$

\footnotetext{
${ }^{232}$ Telegrama no 431, 02/07/1990. De Renato Prado Guimarães, Embaixador do Brasil em Caracas, ao Ministério de Relações Exteriores. Ano 1990 Telegramas Caixa 4.
} 
No Brasil, o jornalista Clovis Rossi, da Folha de S. Paulo, foi uma das raras exceções nos grandes jornais, no que diz respeito ao apoio que estes forneceram ao projeto neoliberal. Em novembro, publicou uma coluna em que considerava pertinente comparar o programa econômico dos dois países, que considerava "quase idênticos". Naquela altura, a Venezuela já havia assinado acordo de renegociação com os bancos credores nos marcos do Plano Brady, que condicionava a renegociação à adesão ao Consenso de Washington. O Brasil ainda estudava a adesão ao Plano. Rossi considerou que a Venezuela partia de uma situação econômica menos grave do que a brasileira no que se refere à inflação e que contava ainda com a vantagem de ter no petróleo uma fonte segura de recursos. Mesmo assim, o jornalista considerou que as autoridades brasileiras minimizavam as dificuldades que o programa liberal enfrentava na Venezuela, quando se referiam elogiosamente às reformas de Andrés Pérez. Esse texto de Clovis Rossi era parte de uma ampla reportagem dedicada à experiência venezuelana com a reforma econômica, composta por diversos textos. Analisando os textos publicados, verificamos a separação entre a realidade da reforma e o discurso do presidente venezuelano. Sem cogitar outra saída, Carlos Andrés Pérez insistia que os ajustes produziam "todos os danos que se pode produzir em uma sociedade" e que "os efeitos positivos vêm a médio e longo prazo". A necessidade das reformas decorria, na interpretação de Pérez, do excesso de estatismo que caracterizou a economia dos países latino-americanos nas décadas precedentes. Para corrigir aquele excesso, se faziam necessárias as privatizações, das quais o presidente tencionava poupar a estatal venezuelana do petróleo.

Tal reticência em apoiar verbalmente as reformas que liderava na prática contrastava com o entusiasmo com que Collor de Mello defendia o novo programa econômico de seu governo. Diferentemente do presidente brasileiro, Andrés Pérez havia construído sua carreira política sobre a imagem de um político nacionalista. Essa imagem se cristalizou especialmente porque, durante seu primeiro mandato, foi ele quem nacionalizou o petróleo e o ferro venezuelano. Percebe-se, assim, que ele tinha responsabilidade sobre o que agora chamava "excesso de estatismo". Embora a prática política de seu segundo mandato fosse contrária àquela do primeiro mandato, Pérez conservava em seu discurso traços daquele período. Chegou mesmo a utilizar um vocabulário próximo ao dos marxistas, quando acusou a burguesia de seu país pela irresponsabilidade de se lançar "aberta e desbocadamente contra os partidos políticos". As suas falas evidenciavam que a coincidência de interesses entre a classe política e a elite econômica do país era apenas parcial, no que diz respeito à aplicação das 
reformas. Tal coincidência era forte o suficiente para colocar as reformas na ordem prioritária, mas se fazia sem que o presidente a incorporasse em seu discurso:

Essa burguesia, essa classe média, que são produtos da transformação que protagonizaram os partidos políticos, agora se voltam contra eles. Isso é muito grave porque se se conseguir desestabilizar os partidos políticos latino-americanos, se criaria u m vazio que seria preenchido pelos governos de força. ${ }^{233}$

\subsubsection{Assuntos fronteiriços}

No dia 20 de julho, os dois presidentes se encontraram no marco fronteiriço número 8 (BV-8), localizado entre a cidade brasileira de Pacaraima, no extremo norte de Roraima e a cidade venezuelana de Santa Elena de Uairén. Thiago Gehre Galvão assinalou, sobre esse encontro, o simbolismo de continuidade das relações que ele envolveu, porque reeditou encontros já acontecidos entre o general Médici e Rafael Caldera, nos anos 1970, assim como entre Jaime Lusinchi e o general Figueiredo, nos anos 1980. E fez notar ainda que: "o objetivo era reforçar um processo global e progressivo de rápida aproximação entre os dois países, que havia sido engatilhado na primeira onda de adensamento da década anterior". ${ }^{234}$ Mônica Vier Loss também considerou a visita carregada de simbolismo, mas por outra razão. Segundo a autora, o simbolismo era geográfico: "o local do encontro era significativo, po is o marco BV8 é o ponto onde a estrada 'Gran Sabana', que liga Caracas à fronteira, se une com a BR$174 " 235$

O encontro presidencial pouco avançou a institucionalidade já criada pelos acordos assinados pelos chanceleres no mês anterior. De fato, o único documento resultante desse encontro foi uma Declaração Conjunta, que cimentava os avanços obtidos até ali. Além disso, foi criada uma comissão binacional para assuntos de fronteira. Naquele momento, os venezuelanos já haviam concluído o asfaltamento da ligação rodoviária entre a fronteira e o sistema de estradas venezuelano. O presidente Collor se comprometeu, na Declaração, a priorizar a construção de uma estrada que conectasse a fronteira à cidade de Boa Vista, completando a conexão rodoviária entre os dois países. O embaixador brasileiro em Caracas, Renato Prado Guimarães, reportou à chancelaria a repercussão favorável que a imprensa

${ }^{233}$ Folha de S. Paulo, 24/11/1990.

234 GALVÃ O, op. cit., p. 136.

${ }^{235}$ LOSS, op. cit., p. 58. 
venezuelana deu ao encontro presidencial. Os dois principais jornais matutinos da capital venezuelana, El Nacional e El Universal, além do vespertino Últimas Notícias, publicaram manchetes de primeira página sobre a reunião, ilustradas com fotos dos dois presidentes e mencionando a importância da articulação bilateral para responder à Iniciativa para as Américas. $^{236}$

Aconteceu uma segunda reunião de vice-chanceleres em Brasília, no dia 14 de novembro de 1990. Aquela reunião assentou as bases para outra, que se realizou em Caracas em maio de 1991 e que resultou na criação de três subcomissões bilaterais para cooperação em matéria de meio ambiente, cartografia e comunidades indígenas. Também ficou acertada, naquela reunião, a cooperação dos dois países para o adensamento dos marcos fronteiriços entre eles, o que de fato ocorreria ao longo de todo o ano seguinte. ${ }^{237}$

Nos encontros presidenciais de 1990 e naqueles que envolveram a participação dos chanceleres e vice-chanceleres, o tema dos indígenas atingiu uma importância até então inédita. Na região de fronteira compartilhada entre os dois países, os indígenas formam a maior parte da população, habitando reservas nacionais e binacionais. As conversas entre as autoridades versaram sobre a cooperação para evitar que a presença de elementos estranhos àquelas comunidades pudesse gerar conflitos com os indígenas e mesmo danos ambientais. Foi designada ainda uma Missão Científica Conjunta, para que fizesse o levantamento dos problemas que envolviam a população Ianomâmi, presente nos dois países. Ficou também pré-marcada uma nova reunião oficial, que deveria acontecer no ano seguinte, para tratar das medidas técnicas necessárias para a reparação do desmatamento causado pelos garimpeiros.

Em discurso ao Congresso venezuelano para prestação anual de contas, pronunciado em janeiro de 1991, o chanceler Reinaldo Figueredo Planchart reportou novas medidas que estavam sendo tomadas pelo governo para defender a fronteira, prevenir danos ambientais e proteger as populações indígenas que ali viviam, contra a recorrente ameaça dos garimpeiros brasileiros. $^{238}$

\footnotetext{
236 “Declaração Conjunta”, publicada em Libro Amarillo correspondente ao ano de 1990, p. 498-500. Telegrama $n^{\circ}$ 479, 21/07/1990. De Renato Prado Gu imarães, Embaixador do Brasil em Caracas, ao Ministério de Relações Exteriores. Ano 1990 Telegramas Caixa 4.

${ }^{237}$ Discurso de prestação de contas do chanceler Armando Durán ao Congresso venezuelano e Comunicado à Imprensa do encontro presidencial, registrado no Libro Amarillo correspondente ao ano de 1991, p. XXXIX e 363-369.

${ }^{238}$ Libro Amarillo correspondente ao ano de 1990, p. XXXV.
} 
Ainda naquele mês, o Jornal de Brasília publicou reportagem de Inácio Muzzi sob o título provocativo "Brasil entregará território à Venezuela". Como se vê, a dramatização dos eventos fronteiriços não era monopólio da imprensa venezuelana, embora a reportagem de Muzzi constituísse mais uma exceção do que regra na cobertura da imprensa brasileira. $\mathrm{O}$ conteúdo da reportagem esclarecia a situação: O Tratado Limítrofe entre o Brasil e a Venezuela, celebrado em 1859, estabelecia que a fronteira entre os dois países, na região da Serra de Parima seria determinada pelo divisor de águas entre as bacias do Orenoco (Venezuela) e do rio Amazonas (Brasil). Na realidade, por estar essa região distante dos centros populacionais e econômicos dos dois países, nunca se soube exatamente a localização daquele divisor de águas, até que os garimpeiros brasileiros começaram a atuar na região. Por dois anos, entre 1988 e 1990, os garimpeiros trabalharam ali. No dia 11 de outubro de 1990, o chefe da divisão de fronteiras do Itamaraty, Geraldo Afonso Muzzi, o diretor geral e setorial de fronteiras da Venezuela, almirante José Velasco, o comandante de selva do exército venezuelano, general Suju Hafo e o chefe do Estado-Maior do Comando Militar da Amazônia Brasileira, general Thaumaturgo, se encontraram na região em disputa para solucionar a questão. $\mathrm{O}$ encontro do dia 11 não terminou em solução e no dia seguinte os dois mais experientes demarcadores dos dois países, o brasileiro Dilermando Moraes Mendes e o venezuelano Rene Gay Pola sobrevoaram a região, concluindo que a zona de mineração pertencia à Venezuela, uma vez que seus rios faziam parte da bacia do Orenoco. Assim, o Brasil "entregou" à Venezuela uma área de cinco mil quilômetros quadrados rica em ouro e cassiterita, segundo a reportagem. ${ }^{239}$

Os insatisfeitos do lado brasileiro eram representados pela União dos Garimpeiros da Amazônia Legal (UGAM) e aludiram à questão do Pirara, quando Joaquim Nabuco, sucessor do Barão do Rio Branco na chancelaria do Brasil, perdeu, em 1904, quase 20 mil quilômetros quadrados do leste de Roraima para o império inglês, por arbitragem do rei Vitor Emanuel III, da Itália. Já na imprensa venezuelana, a alusão histórica ficou pela comparação de José Altino Machado, presidente da UGAM, com Plácido de Castro, chefe das forças brasileiras no território do Acre, então pertencente à Bolívia, reafirmando a disposição do governo brasileiro de promover uma fronteira viva na região, através do projeto Calha Norte, como base para pretensões expansionistas.

${ }^{239}$ Jornal de Brasília, 20/01/1991. 
A reportagem terminava por citar o general brasileiro Santa Cruz, então comandante militar da Amazônia, que recordou episódio de 1975, quando sobrevoou a região em helicóptero com o Ministro de Minas e Energia, Shigeaki Ueki. Ali detectaram alta incidência de urânio. Entre 1978 e 1979, o gerente de Geologia da Companhia de Pesquisa de Recursos Minerais (CPRM), João Orestes Schnneider Santos, percorreu a fronteira leste de Roraima com a Venezuela e tropeçou em evidências de cassiterita e ouro à flor da terra, suspeitando também da existência de vários outros minerais industriais. Em 1982, enviou os resultados de seu trabalho ao Itamaraty, dizendo que a fronteira era muito rica para estar tão mal demarcada, mas a demarcação teve de esperar quase 10 anos para acontecer. Quando enfim as fronteiras começaram a ser demarcadas, o ministro venezuelano do Meio Ambiente se apressou em celebrar o que considerou ser a solução definitiva do problema dos garimpeiros, com ampla repercussão na imprensa venezuelana. ${ }^{240}$

De acordo com o que ficara estabelecido, durante o primeiro semestre daquele ano (entre os dias 27 de fevereiro até o dia $1^{\circ}$ de maio), a Comissão Venezuelano-Brasileira Demarcadora de Limites em Serra Parima empreendeu a Campanha Extraordinária de Demarcação "Parima 91", que utilizou tecnologia de satélites para clarificar a exata localização do divisor de águas entre as bacias do Orenoco e do Amazonas. Entre os dias 30 de abril e dois de maio, aconteceu a Reunião Científica Conjunta de Alto Nível para examinar os problemas que envolviam diversos grupos indígenas na área de fronteira e também para avaliar o dano que essas comunidades sofreram pela interferência dos garimpeiros. ${ }^{241}$ A etapa seguinte dos trabalhos foi feita em escritórios e consistiu na confecção de mapas corrigidos pelas novas informações, entre os dias 15 de maio e 5 de julho, aniversário da independência venezuelana. Novamente os trabalhos de demarcação fronteiriça foram retomados entre os dias 15 de outubro até 13 de dezembro daquele ano. ${ }^{242}$

\footnotetext{
${ }^{240}$ Telegrama n ${ }^{\circ}$ 121, 11/03/1991. De Renato Prado Guimarães, Embaixador do Brasil em Caracas, ao Ministério de Relações Exteriores. Ano 1991 Telegramas Caixa 7.

${ }^{241}$ Libro Amarillo correspondente ao ano de 1991, p. XXXIX.

${ }^{242}$ Libro Amarillo correspondente ao ano de 1991, p. 315.
} 


\subsection{CRISE POLÍTICA}

Naquele contexto, a diplomacia brasileira estava empenhada em articular uma maior integração com os vizinhos latino-americanos, vista não como alternativa à integração com os Estados Unidos, mas como etapa prévia de um processo de liberalização comercial que deveria se estender posteriormente ao âmbito pan-americano e mundial. O Brasil assinou, conjuntamente com a Argentina, Paraguai e Uruguai, o Tratado de Assunção, em março. Esse Tratado marca o nascimento do Mercosul (Mercado Comum do Sul) e previa que os países envidassem esforços para que no dia 31 de dezembro de 1994 estivessem zeradas as barreiras tarifárias e não tarifárias para o comércio regional, além de obter a coordenação de política macroeconômicas e a constituição de uma tarifa externa comum. ${ }^{243}$ A importância desse evento para as relações entre o Brasil e a Venezuela está em que, a partir daquele momento, permaneceria no discurso diplomático dos dois países a possibilidade de integração do Mercosul com a Comunidade Andina de Nações (CAN), da qual a Venezuela fazia parte e mesmo com o Grupo dos Três (G3), que era um projeto de formação de uma área de livre comércio envolvendo a Venezuela, a Colômbia e o México, cujas negociações já eram então públicas. Ou seja, as relações bilaterais foram enquadradas no contexto mais amplo de formação de blocos econômicos regionais.

O segundo semestre de 1991 foi marcado pela discordância nos jornais brasileiros quanto ao sucesso das reformas econômicas na Venezuela. Em julho, a Folha de S. Paulo publicou matéria de Efrém Ribeiro destacando o crescimento da miséria e do desemprego naquele país. Em agosto, o Jornal do Brasil reproduziu matéria do The Washington Post, em que se afirmou haver pânico na Venezuela causado pelas revelações de envolvimento de políticos e militares com o narcotráfico. Já o Correio Braziliense adotou outro ponto de vista em setembro, quando reportagem de Tatiana Montezuma destacou que o processo de modernização, desregulamentação e busca de eficiência já estava surtindo efeito e que "os venezuelanos demonstraram satisfação com o governo". O otimismo da reportagem do Correio era tão grande que mesmo os tímidos acordos obtidos para renegociação da dívida externa foram retratados como surpreendentes "em função da eficiência e do retorno

\footnotetext{
${ }^{243}$ PRESSER, Mario F. “Abertura Externa e Integração Regional: o Caso do Mercosul”. In: BATTA GLINI, op. cit., p. 87.
} 
financeiro". Gesner de Oliveira, escrevendo para a Folha de S. Paulo em novembro, fez avaliação similar sobre as reformas venezuelanas. Apesar de alertar para os desafios políticos envolvidos no processo, citando como exemplo o Caracazo, considerou que a Venezuela fazia o "dever de casa" e era um dos "bons alunos em ajuste econômico", constituindo exemplo para o Brasil. Há razões, porém, para acreditar que esse tipo de cobertura era mais fiel ao posicionamento editorial dos jornais frente à ideologia neoliberal do que à apuração dos fatos. Isto porque, em curto espaço de tempo, outras reportagens podiam contradizer frontalmente as anteriores. Exemplo disso foi a reportagem da Gazeta Mercantil publicada no dia 5 de dezembro, sob o título "É crescente a inquietação social enquanto avança a queda do padrão de vida". A Gazeta citou o influente intelectual venezuelano Arturo Uslar Pietri, quando disse: "Temos na Venezuela uma sensação de sufocação. O governo não funciona. As instituições não funcionam. Não existem mecanismos para fornecer padrão mínimo de vida". 244

Enquanto os jornais brasileiros polemizavam em suas avaliações sobre as reformas venezuelanas, as autoridades políticas dos dois países aprofundavam a cooperação bilateral. Em setembro, o deputado brasileiro Ulysses Guimarães foi convidado pelo Congresso venezuelano a participar das Jornadas de Revisão Constitucional Jóvito Villalba. ${ }^{245}$ A proximidade de Guimarães com os venezuelanos era antiga e remontava a sua posição de liderança da oposição parlamentar à ditadura brasileira. Na década de 1980, Guimarães foi presidente do partido de oposição Movimento Democrático Brasileiro (MDB), que depois agregou a palavra "Partido" ao nome, constituindo o PMDB. Esse partido era especialmente próximo do partido venezuelano da Ação Democrática, com quem compartilhava um programa socialdemocrata.

Entre os dias 18 e 21 de novembro, o presidente venezuelano realizou uma visita oficial ao Brasil, a convite do presidente brasileiro. As conversas mantidas pelos presidentes versaram sobre as relações bilaterais, com especial ênfase em assuntos de cooperação econômica e comercial. Dentre os documentos que resultaram daquele encontro, figuram o Acordo de Cooperação entre as empresas estatais CVG e Companhia Vale do Rio Doce, o Memorando de Entendimento entre a Companhia Anônima de Administração e Fomento

\footnotetext{
${ }^{244}$ Folha de S. Paulo, 03/07/1991. Jornal do Brasil, 08/08/1991. Correio Braziliense, 08/09/1991. Folha de S. Paulo, 17/11/1991. Gazeta Mercantil, 05/12/1991.

${ }^{245}$ Telegrama n ${ }^{\circ}$ 518, 23/09/1991. De Renato Prado Guimarães, Embaixador do Brasil em Caracas, ao Ministério de Relações Exteriores. Ano 1991 Telegramas Caixa 7.
} 
Elétrico (CADAFE, da Venezuela) e a Eletrobrás e um Comunicado à Imprensa. ${ }^{246}$ Em relação a este último documento cabe destacar que expressou a congratulação dos dois presidentes com a visita realizada em agosto daquele mesmo ano pelos ministros venezuelanos de Fomento e Coordenação e de Planejamento ao Brasil, a convite do ministro brasileiro de Economia, Fazenda e Planejamento. A comitiva do presidente venezuelano estava composta por mais 40 empresários; por executivos da PDVSA, que buscavam aumentar as vendas de petróleo ao Brasil; e pelo chanceler Armando Durán. Em sua agenda constaram encontros com os governadores de São Paulo, Luiz Antonio Fleury Filho, do Rio de Janeiro, Leonel Brizola, do Amazonas, Gilberto Mestrinho e de Roraima, Ottomar Pinto. ${ }^{247}$

Aquela visita marcou o início das negociações para o estabelecimento de um Acordo de Complementação Econômica, que institucionalizasse o crescimento do comércio bilateral. Também foi saudada a realização de encontros empresariais em Manaus, Ciudad Bolívar e Boa Vista, além do Seminário sobre Perspectivas de Negócios Associados entre Brasil e Venezuela, que aconteceu na Ciudad Guayana, com patrocínio da CVG. Além de todas essas evidências de que as relações bilaterais já se adensavam progressivamente antes do encontro de Guzmania, em 1994, deve-se registrar ainda a realização, paralelamente à visita presidencial de 1991, de um encontro empresarial patrocinado pelas Câmaras binacionais de Indústria e Comércio em São Paulo e no Rio de Janeiro. ${ }^{248}$ Naquela ocasião, o enquadramento institucional da Associação Latino-Americana de Integração (ALADI), ainda era considerado o mais apropriado para as negociações comerciais. Nas reuniões dos anos seguintes, porém, a ALADI seria gradualmente entendida como um mecanismo inadequado aos novos tempos e as negociações seriam pautadas pela formação de novas instituições, como o Mercosul, a Área de Livre Comércio Sul-Americana (ALCSA) e a Área de Livre Comércio das Américas (ALCA).

O ano de 1992 testemunhou o ápice da crise política na Venezuela e no Brasil. Enquanto na Venezuela ocorreram duas tentativas de golpe de Estado, em fevereiro e em novembro, no Brasil o presidente Fernando Collor de Mello tentou se defender de escândalos de corrupção que, somados ao fracasso de sua gestão econômica, acabaram lhe custando o cargo em dezembro. Um contexto assim turbulento não favoreceu as iniciativas diplomáticas

\footnotetext{
${ }^{246}$ Libro Amarillo correspondente ao ano de 1991, p. 167.

${ }^{247}$ Folha de S. Paulo, 17/11/1991.

${ }^{248}$ Comunicado à Imprensa do encontro presidencial, registrado no Libro Amarillo correspondente ao ano de 1991, p. 363-369.
} 
de maior envergadura, como era o projeto de aproximação entre os dois países. Mais ainda, as rebeliões militares de fevereiro e novembro na Venezuela fizeram com que as viagens presidenciais, que sempre foram uma estratégia destacada da diplomacia de Andrés Pérez, ficassem reduzidas a apenas três ao longo de todo o ano: o comparecimento à reunião de presidentes dos países membros do Conselho de Segurança da ONU e ao Fórum Econômico Mundial, na Suíça, entre os dias finais de janeiro e começo de fevereiro, e ao funeral do líder socialdemocrata alemão Willy Brandt, no dia 17 de outubro.

Nessa conjuntura não ocorreram mais visitas bilaterais de altas autoridades. Os relatórios anuais da diplomacia venezuelana registraram, em suas menções ao Brasil, apenas a ocorrência de incidentes fronteiriços e o início de negociações pela celebração de um Acordo de Complementação Econômica e de um Acordo de cooperação aerocomercial, ainda em janeiro. ${ }^{249}$ Mas a análise dos relatos e percepções da crise, especialmente aquelas registradas na imprensa, constituem importantes revelações sobre os interesses que permeavam as relações que se desenvolveram ao longo dos anos seguintes.

Era evidente a situação de instabilidade política na Venezuela quando o Embaixador do Brasil em Caracas escreveu ao Ministério das Relações Exteriores, em 4 de fevereiro de 1992, para reportar que o governo havia suspendido garantias constitucionais, como o direito de ir e vir e o direito de reunião. O objetivo dessa medida era combater uma insurreição que começara na madrugada e se estendeu pela manhã, até terminar com a rendição dos líderes rebeldes, por volta do meio dia. ${ }^{250}$ Desde a embaixada, era possível escutar os tiros dos confrontos em Caracas, que envolveram majoritariamente militares, mas também alguns civis, dos quais a maioria eram estudantes universitários. ${ }^{251}$ No dia seguinte ao levante, o Embaixador relatou a volta à normalidade: “As lojas estão, em sua grande maioria, abertas; os transportes públicos funcionam, inclusive o metrô, este com passagens gratuitas, no que parece ser um esforço do governo para convencer o conjunto da população a trabalhar

\footnotetext{
${ }^{249}$ Libro Amarillo correspondente ao ano de 1992, p. 267.

${ }^{250}$ Telegrama no 86, 04/02/1992. De Renato Prado Guimarães, Embaixador do Brasil em Carac as, ao Ministério de Relações Exteriores. Ano 1992 Telegramas Recebidos Caixa 54.

Mais informações sobre o desenrolar dos acontecimentos naquela noite, os atores envolvidos e suas motivações podem ser encontrados em BARRERA TYSZKA; MARCANO. op. cit.;

MARINGONI (2004 e 2008); MENDES, op. cit.

${ }^{251}$ Telegrama n ${ }^{\circ}$ 87, 05/02/1992. De Renato Prado Guimarães, Embaixador do Brasil em Caracas, ao Ministério de Relações Exteriores. Ano 1992 Telegramas Recebidos Caixa 54.
} 
normalmente". ${ }^{252}$ Ainda segundo o Embaixador, verificou-se que a insurreição foi liderada por alguns poucos oficiais de baixa patente, que reuniram um pequeno contingente das Forças Armadas venezuelanas em uma tentativa de liderar o que, esperavam, se tornaria uma revolução a partir da adesão popular.

O encerramento das batalhas militares significou, contudo, o início de uma batalha semântica na imprensa brasileira. Uma batalha que foi bastante desigual, dada a concentração dos contendores em apenas um dos lados. A questão se colocou em torno do nome pelo qual se deveria chamar o episódio e a grande maioria dos repórteres, analistas e editores referiu-se a ele como golpe, ou tentativa de golpe. Os líderes da chamada intentona (termo atribuído ao movimento insurrecional ocorrido no Brasil em 1935 liderado pelo Partido Comunista do Brasil - PCB) ficaram conhecidos como golpistas, estigma que o líder maior da insurreição, o tenente-coronel Hugo Chávez Frías, levou até a sua eleição à Presidência da República, em dezembro de 1998.

A reportagem da Gazeta Mercantil, publicada no dia 5 de fevereiro, trazia como título: "Líder golpista reconhece fracasso e pede a aliados que se rendam". ${ }^{253}$ No mesmo dia, o Correio Braziliense apresentou a seguinte notícia: "Fracassa golpe militar na Venezuela".254 O Jornal de Brasília publicou um editorial sob o título "Golpe Frustrado". ${ }^{255} \mathrm{Na}$ Folha de S. Paulo, o editorial chamou-se "Golpe na Venezuela". ${ }^{256}$ O mesmo ocorreu na reportagem do Jornal do Brasil que também se referia a "golpe" no título: "Venezuela derrota tentativa golpista de jovens oficiais". ${ }^{257}$ O Estado de S. Paulo, com três dias de atraso, publicou o editorial "A tentativa de golpe na Venezuela", ${ }^{258}$ no qual associaram a rebelião dos "caraspintadas", militares direitistas da Argentina à insurreição venezuelana, ambas caracterizadas como "idiossincrasia castrense".

Também o comunicado emitido pelo presidente Fernando Collor de Mello, reproduzido pelo Correio Braziliense, fazia menção à necessidade de defesa da América Latina:

\footnotetext{
${ }^{252}$ Telegrama no 91, 05/02/1992. De Renato Prado Guimarães, Embaixador do Brasil em Caracas, ao Ministério de Relações Exteriores. Ano 1992 Telegramas Recebidos Caixa 54.

${ }^{253}$ Gazeta Mercantil, 05/02/1992.

${ }^{254}$ Correio Braziliense, 05/02/1992.

${ }^{255}$ Jornal de Brasília, 05/02/1992.

${ }^{256}$ Folha de S. Paulo, 05/02/1992.

257 Jornal do Brasil, 05/02/1992.

${ }^{258}$ O Estado de S. Paulo, 08/02/1992.
} 
Trago minha irrestrita solidariedade ao presidente Carlos Andrés Pérez, no mo mento em que enfrenta, com determinação e êxito, essa ameaça a seu mandato, que é também uma afronta às liberdades públicas e individuais, e a democracia que queremos firme e definitiva, na A mérica Latina e em todo o mundo. ${ }^{259}$

No editorial citado do Jornal de Brasília, encontra-se a seguinte referência: "O ciclo de golpes e governos militares foi suficientemente sangrento, opressivo e corrupto para demonstrar que, se a democracia por si só não resolve os problemas nacionais latinoamericanos, muito menos o fazem os regimes de força". ${ }^{260}$ Na Folha de S. Paulo, o colunista Josias de Souza escreveu:

Não se sabe até quando haverá abaixo da linha do Equador u ma fatia de funcionários públicos fardados desempenhando o papel de semideuses. Mas não há qualquer dúvida sobre a necessidade de esmagar todos aqueles que resolverem apontar a arma adquirida com verba do erário contra a ordem constitucional vigente. ${ }^{261}$

O Jornal do Brasil foi igualmente incisivo em seu editorial: "Nada é mais previsível do que certa incapacidade militar de se adaptar à democracia, embora, neste final de século, a democracia tenha soprado pelo mundo com intensidade espetacular". ${ }^{262}$

Segundo o editorial do Correio Braziliense:

O episódio do levante armado expõe com rudes caracteres a renitente ignorância de alguns segmentos das Forças Armadas latino-americanas. A ideia da impraticabilidade golpista como alternativa de força para mudança do poder parece distante ainda de tais enquistamentos castrenses. Nessa consciência que se compraz em conceber o mundo como expressão de interesses personalistas, capazes de prevalecer apenas pela tutela brutal das instituições, não cabe apreciar a evolução política mundial a partir do sepultamento dos regimes discricionários e a consagração do governo democrático. ${ }^{263}$

Por fim, $O$ Globo explicitou a comparação entre a conjuntura política venezuelana e o passado autoritário brasileiro, evidenciando a influência que a experiência vivida no Brasil exerceu sobre o olhar dos brasileiros para a Venezuela:

Ao Brasil e ao continente, interessa que esse quadro evolua positivamente. Diferenças à parte, os nossos objetivos são os mesmos: construir sociedades viáveis, onde os índices de desigualdade social percam o aspecto indecoroso que exibem ainda hoje. Enão é com golpes militares que se consegue is to. ${ }^{264}$

\footnotetext{
${ }^{259}$ Correio Braziliense, 05/02/1992.

260 Jornal de Brasília, 05/02/1992.

${ }^{261}$ Folha de S. Paulo, 05/02/1992.

262 Jornal do Brasil, 05/02/1992.

263 Correio Braziliense, 06/02/1992.

${ }^{264}$ O Globo, 08/02/1992
} 
Cabe mencionar como exceção a esse tipo de argumento o texto de Heraclio Salles, colunista do Jornal do Brasil, que apresentou uma interpretação distinta dos fatos: "O que houve em Caracas no dia 4 deste mês não foi golpe, mas o exercício do direito de insurreição. (...) Golpe, hoje, na América Latina, é o governo que dá". ${ }^{265}$ A argumentação do autor, que fora professor na Faculdade de Direito do Distrito Federal, recorreu à teoria de John Locke para justificar a insurreição contra um governo que contrariou as promessas em razão das quais fora eleito: "Se, uma vez conquistado o poder com os gorjeios despistatórios do populismo, eles passam a usá-lo para fazer o contrário do que prometeram o que ocorre é a devolução automática do poder à sua única fonte: a soberania popular”. Alguns dias antes, no mesmo Jornal do Brasil, o enviado especial a Caracas, Luiz Eduardo Rezende, também evitou identificar os rebeldes como ameaça à democracia, preferindo se referir ao bloqueio que o sistema político venezuelano representava às aspirações populares, na medida em que conferia excessivo protagonismo às cúpulas partidárias, em detrimento da vontade dos eleitores. $^{266}$

A interpretação de Heraclio Salles não prevaleceu na maioria das reportagens, análises e editoriais publicados à época nos jornais brasileiros. Antes, o prisma através do qual se considerou o episódio de quatro de fevereiro foi a experiência brasileira do golpe e ditadura militar de 1964-1985. Cabe dizer que, condenando simultaneamente a insurreição venezuelana e o golpe brasileiro de 1964, aqueles jornais buscavam construir uma memória que apagava a posição que realmente tiveram. Se em 1992 os editoriais condenavam a intervenção militar na política, tal não fora a sua posição em 1964, quando apoiaram o golpe, como demonstra Maria Helena Capelato. De fato, todos os maiores jornais brasileiros que serviram de fonte a este trabalho apoiaram o golpe militar de 1964 e seguiram apoiando a ditadura até $1968 .^{267}$

Nesse contexto de incertezas políticas, o embaixador Renato Prado Guimarães chegou a advertir seus interlocutores no Ministério sobre a possibilidade de que as negociações com a Venezuela diminuíssem porque a crise política abalara o desempenho econômico daquele

\footnotetext{
265 Jornal do Brasil, 13/02/1992. Grifos do original.

266 Jornal do Brasil, 09/02/1992.

267 CAPELATO, Maria H. R. História do Tempo Presente: a Grande Imprensa como fonte e objeto de estudo. Rio de Janeiro: Ed. FGV, no prelo.
} 
país. ${ }^{268}$ No entanto, apesar da crise política que abalava a legitimidade do presidente Collor de Mello e da insurreição ocorrida na Venezuela, os contatos comerciais entre os dois países continuaram.

Em abril, uma missão da empresa estatal brasileira do setor de energia, Eletrobrás, visitou a Venezuela para prestar apoio técnico à estatal venezuelana, CADAFE, dando sequência à cooperação binacional em matéria de tecnologia. Empresas brasileiras interessadas em realizar comércio com a Venezuela continuavam realizando consultas junto ao Ministério das Relações Exteriores e à Embaixada em Caracas. Ao perceber que as negociações tinham continuidade das negociações, as preocupações do Embaixador brasileiro se amainaram, permitindo que ele vislumbrasse novas oportunidades para a retomada do comércio bilateral.

Diante da constatação de que as negociações continuavam, comentou que as oportunidades estavam sendo desperdiçadas, não por causa da instabilidade política, mas pela insuficiência de recursos e pessoal destinado para atuar no setor comercial (SECOM) da Embaixada. Esta consideração foi feita no mesmo telegrama no qual relatou o incremento do comércio bilateral nos primeiros anos da década de 1990. Desde a Guerra do Golfo, o Brasil voltara a comprar petróleo venezuelano, incrementando as cifras do comércio. Também as exportações brasileiras haviam aumentado naquele período, garantindo ao Brasil a condição de quinto maior parceiro comercial da Venezuela e primeiro entre os países da Associação Latino-Americana de Integração (ALADI). A economia venezuelana crescera em 1991 8,5\%, gerando oportunidades de negócios que provocaram o aumento do interesse dos empresários brasileiros por aquele mercado, mas que eram desperdiçadas pela incapacidade dos poucos funcionários do setor comercial em processá-las porque estavam sobrecarregados. Segundo o embaixador: "o número de consultas e visitas tem crescido significativamente, assim como o número de empresas brasileiras que abriram escritório ou designaram representante na Venezuela nos últimos dois anos". 269

\footnotetext{
268 Telegramas no 226, 18/03/1992 e no 312, 09/04/1992. De Renato Prado Guimarães, Embaixador do Brasil em Caracas, ao Min istério de Relações Exteriores. Ano 1992 Telegramas Recebidos Caixa 54.

${ }^{269}$ Telegrama no 765, 08/10/1992. De Renato Prado Guimarães, Embaixador do Brasil em Caracas, ao Ministério de Relações Exteriores. Ano 1992 Telegramas Recebidos Caixa 54.
} 


\subsection{AS RELAÇÕES BILATERAIS DIANTE DO AGRAVAMENTO DA CRISE POLÍTICA}

O comércio bilateral prosperava, mas foi nesse contexto que a situação política tanto no Brasil, como na Venezuela tornou-se crítica.

A crise política que já se enunciava desde 1990 envolvendo o presidente Collor de Mello atingiu seu ponto culminante. Já nesse ano começaram a circular na imprensa brasileira acusações de corrupção envolvendo o ex-tesoureiro da campanha de Fernando Collor de Mello à Presidência, Paulo César Farias. Em agosto de 1991, o Jornal do Brasil publicou uma série de reportagens sobre irregularidades na administração da Legião Brasileira de Assistência (LBA), presidida pela primeira-dama Rosane Collor que, diante de tais as acusações foi obrigada a abandonar a direção da LBA. Pouco a pouco, o círculo mais próximo do presidente era exposto a acusações de corrupção, desgastando ainda mais a imagem de Collor, que já se ressentia do fracasso de seu governo na tentativa de estabilizar a economia. Em maio de 1992, foi o próprio irmão do presidente, Pedro Collor, quem o acusou de ser sócio de Paulo César Farias em negócios não declarados à Receita Federal. No dia 26 desse mês, foi criada uma Comissão Parlamentar de Inquérito (CPI) para investigar as denúncias contra o presidente. À medida que as investigações revelavam detalhes do esquema de corrupção operado conjuntamente por Fernando Collor e Paulo César Farias, o presidente foi se enfraquecendo politicamente. No dia 29 de setembro, a Câmara Federal autorizou a abertura de processo contra ele e o Senado determinou o seu afastamento do cargo, o que aconteceu no dia 2 de outubro, quando o vice-presidente, Itamar Franco, assumiu a Presidência em caráter temporário, até a renúncia definitiva de Fernando Collor em 29 de dezembro daquele ano. ${ }^{270}$

Pouco antes do "impeachment" de Collor de Mello, também se agravou a situação política na Venezuela. No dia 27 de novembro ocorreu uma nova insurreição militar, liderada

\footnotetext{
270 Detalhes desse conturbado processo podem ser encontrados em CONTI, Mario S. Notícias do Planalto: a imprensa e Fernando Collor. São Paulo: Companhia das Letras, 1999. Brasílio Sallum Júnior e Gu ilherme Stolle Paixão e Casarões citaram dados de pesquisa do Instituto Datafolha para demonstrar que, em março de 1992 , após dois anos do governo Collor, apenas $18 \%$ dos brasileiros avaliaram positivamente o seu governo, enquanto outros $50 \%$ avaliaram o governo como ruim ou pés simo. $38 \%$ dos entrevis tados consideraram o governo regular, e o restante não soube responder. SALLUM JR., Brasílio; CASARÕES, Guilherme S. P. "O impeachment do presidente Collor: a literatura e o processo". In: Lua Nova, São Pau lo, nº 82, 2001, p. 176.
} 
por oficiais ligados ao grupo bolivariano de Hugo Chávez. Coube ao chanceler brasileiro, Fernando Henrique Cardoso, avisar ao presidente recém-empossado Itamar Franco sobre o ocorrido. Este enviou ao presidente venezuelano uma nota de repúdio à 'tentativa de tomada do poder pela força" e de apoio à democracia venezuelana. Ao Jornal do Brasil, Fernando Henrique Cardoso acreditava que houvesse risco de contaminação aos países vizinhos e, neste sentido, afirmou: “A democracia hoje é um valor universalmente respeitado". ${ }^{271}$

Cabe notar que em uma década a Venezuela, antes considerada uma democracia exemplar, acabou sendo vista como um país "primitivo", o "mais explosivo da América Latina", segundo reportagem da Folha de S. Paulo:

Faz 34 anos que os venezuelanos elegem seu presidente. Mas politicamente a
Venezuela é um Estado primitivo. A democracia é frágil e a população
aparentemente desconhece métodos civilizados de protestos. Uma noite de
"panelaço" em Caracas é uma noite de guerra. Os manifestantes se armam de pau e
pedra e vão para as ruas enfrentar a polícia. Há grupos armados que atiram em todas
as direções. Morrem dezenas de pessoas. O país não consegue fazer manifestações
pacíficas.

A situação política modificou-se a tal ponto que se inverteram os termos da comparação em relação aos processos políticos venezuelano e brasileiro. Se, como mostramos anteriormente, nos anos finais da ditadura militar, a democracia venezuelana era exaltada como modelo quando comparada à incapacidade de se implementar um regime democrático duradouro no Brasil, nos anos 1990 a grande imprensa brasileira passou a enaltecer a democracia participativa e civilizada que vigorava no país. Citamos como exemplo de inversão das avaliações os argumentos de Luiz Adolfo Pinheiro, diretor de redação do Correio Braziliense:

\begin{abstract}
A forma pacífica, legalista, como se produziram no Brasil eventos da maior importância, a partir da campanha das "diretas já" até as mais recentes manifestações de rua, é algo que não apenas o País, mas também outras nações latino-americanas não conheciam. Por muito menos do que isso, já houve duas tentativas de golpe este ano na Venezuela, a mbas de caráter militar, enquanto o Peru anda em sobressalto e as chamas ainda não estão de todo apagadas na América Central. ${ }^{273}$
\end{abstract}

Já como presidente em exercício, Itamar Franco deu continuidade às iniciativas de integração latino-americana e também propôs novos projetos. Tais projetos não se desviaram

\footnotetext{
271 Jornal do Brasil, 28/11/1992.

272 Folha de S. Paulo, 28/1 1/1992.

${ }^{273}$ Correio Braziliense, 29/11/1992.
} 
da orientação impressa pela diplomacia brasileira nos anos do governo Collor de Mello, apenas se aprofundou a liberalização comercial.

O contexto em que Itamar assumiu o poder era pouco favorável para mudanças bruscas de direção. No âmbito doméstico, o novo presidente se viu diante do desafio de governar um país que se caracterizava por um sistema político fragilizado pela experiência do impeachment. No âmbito externo, a permanência da crise econômica restringia a capacidade do governo de resistir ao receituário neoliberal recomendado pelos Estados Unidos.

Em dezembro de 1992, na VI Reunião de Cúpula do Grupo do Rio em Buenos Aires, Itamar Franco propôs a Iniciativa Amazônica, que deveria conduzir à formação de uma área de livre comércio entre os países da região. No ano seguinte, sugeriu que os países membros do Mercosul, da Comunidade Andina, da Iniciativa Amazônica e mais o Chile iniciassem negociações para a constituição de uma Área de Livre Comércio Sul-Americana (ALCSA). O presidente brasileiro esperava que a ALCSA pudesse ser formada em um prazo de dez anos. $^{274}$

Nesse contexto, a crise política vivida nos dois países (Brasil e Venezuela) afetou as relações bilaterais, provocando diminuição dos encontros de autoridades e os encontros de comércio bilaterais de 1993 foram menos numerosos em comparação com os anos anteriores. Por um breve momento entre o impeachment de Collor e de Carlos Andrés Pérez, as relações entre os dois países pareceram reviver a assincronia que Paulo Vizentini apontou como característica marcante dessas mesmas relações durante o século XX, em que os diferentes ritmos da política doméstica afastaram maiores possibilidades de cooperação. ${ }^{275}$

Quando o presidente Itamar Franco completou sete meses no cargo, no começo de maio de 1993, o presidente da Suprema Corte da Venezuela recomendou aos outros 13 juízes que votassem pela abertura de um processo contra o presidente Andrés Pérez por malversação de US\$ 17,5 milhões. Dez dias depois, Humberto Celli, presidente do partido da Ação Democrática, ao qual Carlos Andrés Pérez era filiado, solicitou a ele que renunciasse ao cargo. Isolado, sem o apoio popular, sem o apoio de seu partido, sem apoio nas Forças

\footnotetext{
${ }^{274}$ HIRST, Monica; PINHEIRO, Letícia. "A política externa do Brasil em do is tempos". In: Revista Brasileira de Política Internacional. Ano 38, $\mathrm{n}^{\circ} 1,1995$, p. 5-23.

275 VIZENTINI, Paulo. "Venezuela e Brasil na Política Internacional: Um Ensaio Exploratório". In: GUIMARÃES, op. cit., p. 24.
} 
Armadas, o presidente foi afastado provisoriamente pelo Senado venezuelano no dia 21 de maio, para que respondesse às acusações de corrupção que lhe eram feitas. No dia seguinte, foi empossado interinamente o Presidente do Congresso, Octavio Lepage, ligado a um grupo do partido da $\mathrm{AD}$ aliado do ex-presidente Jaime Lusinchi, rival político de Carlos Andrés Pérez. Lepage continuou como presidente oficial até o dia 31 de agosto, quando o Congresso decidiu seu afastamento definitivo. ${ }^{276}$

Durante o processo contra o presidente venezuelano, não faltaram comparações entre o seu caso e o de Fernando Collor no Brasil. Poucos dias antes da Corte Suprema autorizar o julgamento de Carlos Andrés Pérez, o ex-presidente venezuelano Rafael Caldera, candidato novamente para as eleições do final do ano, fez declarações ao jornal El Universal afirmando que a Venezuela não era menos capaz do que o Brasil para destituir um presidente envolvido em escândalos de corrupção num contexto democrático. ${ }^{277} \mathrm{Na}$ imprensa brasileira, o Jornal do Brasil, em editorial de 23 de maio, após a decisão da Suprema Corte, considerou que o afastamento dos dois presidentes foi feito com instrumentos democráticos e refletiu a "mudança dos tempos" na América Latina, onde a população não mais aceitava corr upção e desmandos. ${ }^{278}$ Em caráter oficial, o presidente Itamar Franco enviou mensagem de apoio a Octavio Lepage, na qual mencionou o impeachment de Collor como incentivador do processo na Venezuela. ${ }^{279}$

No dia 5 de junho, Ramón Velásquez foi escolhido pelo Congresso como novo presidente da Venezuela, incumbido de exercer o cargo até a posse do presidente que seria diretamente eleito no final daquele mesmo ano. Os poucos meses em que exerceu o poder foram marcados pelo imobilismo político decorrente da crise institucional do país.

Entre os dias 24 e 26 de agosto, o chanceler venezuelano Fernando Gerbasi visitou o Brasil onde participou da Primeira Reunião do Mecanismo de Consulta Política. ${ }^{280}$ Naquele

\footnotetext{
${ }^{276}$ Folha de S. Paulo, 08/05/1993; Jornal de Brasília, 18/05/1993; Folha de S. Paulo, 22/05/1993; O Estado de S. Paulo, 02/09/1993.

${ }^{277}$ Telegrama n ${ }^{\circ}$ 215, 06/05/1993. De Renato Prado Gu imarães, Embaixador do Brasil em Caracas, ao Ministério de Relações Exteriores. Ano 1993 Telegramas Recebidos Caixa 7. Ao longo de todo o mês de maio, o embaixador brasileiro enviou regularmente ao MRE os títulos de reportagens dos principais jornais venezuelanos, e ocasionalmente reportou também o seu conteúdo.

278 Jornal do Brasil, 23/05/1993.

${ }^{279}$ Correio Braziliense, 23/05/1993.

${ }^{280}$ O Mecanismo fora instituído mais de três anos antes, durante encontro de chanceleres realizado em junho de 1990, como uma instancia de cooperação bilateral que envolvia delegações dos dois países, chefiadas pelos Ministros das Relações Exteriores.
} 
mesmo mês aconteceu, na região de fronteira, um massacre de indígenas Ianomâmis, que teve ampla repercussão nas relações entre os dois países a ponto de provocar a criação de uma Comissão Binacional de investigação em setembro. ${ }^{281}$

Logo após esse episódio, os ministros venezuelanos de Fomento e do Escritório Central de Coordenação e Planejamento (Cordiplan) visitaram o Brasil, a convite do ministro da Economia, para negociações da integração comercial, visando à assinatura de um Acordo de Complementação Econômica. ${ }^{282}$ Em decorrência dos incidentes na fronteira, o governo venezuelano anunciou a disposição de realizar patrulhas conjuntas com militares brasileiros na área, além de criar uma zona especial de segurança na fronteira entre o estado venezuelano do Amazonas e o estado brasileiro de Roraima, a oeste do estado, onde se localiza a Serra de Parima. ${ }^{283}$

Em outubro, a embaixada brasileira acompanhou a iniciativa venezuelana de negociar com o México e a Colômbia um acordo de complementação econômica, que daria origem ao Grupo dos Três. O acordo de complementação econômica contemplava 15 temas: programa de liberalização, normas técnicas e de origem, salvaguardas, práticas desleais, propriedade intelectual, serviços financeiros e de telecomunicações, bem como investimentos e compras governamentais. ${ }^{284} \mathrm{O}$ México conduzia essas negociações em paralelo com a adesão ao Acordo Norte-Americano de Livre Comércio (NAFTA, na sigla em inglês), o que já havia gerado descontentamento em seus parceiros venezuelanos, como mencionado acima. No mês seguinte, porém, o governo venezuelano saudou a aprovação do NAFTA pelo Congresso dos Estados Unidos. O novo Embaixador do Brasil na Venezuela apurou, em conversa com o presidente do Instituto de Comércio Exterior daquele país, que o seu governo encarava a formação do G3 “como um passo na aproximação com o NAFTA", que poderia levar inclusive à adesão ao Acordo. ${ }^{285}$

Às vésperas da eleição presidencial daquele ano, o presidente em exercício Ramón Velásquez decidiu paralisar as privatizações até que o novo presidente fosse empossado. A agitação popular continuava na Venezuela e a classe política, de maneira geral, era alvo dessa

\footnotetext{
${ }^{281}$ Libro Amarillo correspondente ao ano de 1993, p. 210.

${ }^{282}$ Libro Amarillo correspondente ao ano de 1993, p. 442.

283 Jornal do Brasil, 16/09/1993.

${ }^{284}$ Telegrama n ${ }^{\circ}$ 580, 13/10/1993. De Dante Coelho de Lima, Ministro Conselheiro, ao Ministério de Relações Exteriores. Ano 1993 Telegramas Recebidos Caixa 7.

${ }^{285}$ Telegrama $\mathrm{n}^{\mathbf{0}}$ 675, 19/11/1993. De Clodoaldo Hugueney Filho, Embaixador do Brasil em Caracas, ao Ministério de Relações Exteriores. Ano 1993 Telegramas Recebidos Caixa 7.
} 
revolta que a identificava com a corrupção e o neoliberalismo. Mesmo assim, muitos membros do governo se viram perplexos diante da decisão do presidente, segundo relatou o embaixador Clodoaldo Hugueney: "A referida medida traz no seu bojo sérias implicações, pois retirará das mãos do governo recursos vultosos que estavam sendo utilizados para atenuar o déficit fiscal". ${ }^{286}$

A desaceleração das reformas econômicas não foi completa e Velázquez promulgou, em novembro, uma nova Lei Geral de Bancos e Outras Instituições, inspirada nos princípios desregulamentadores do Consenso de Washington. Com esta medida, o Banco Central da Venezuela ganhou maior autonomia e diversos bancos estatais se prepararam para a retomada das privatizações. O capital estrangeiro foi autorizado a participar no sistema bancário do país com o intuito de conseguir recursos para controlar a crise econômica. O Embaixador era cético em relação a essa medida e comentou que as incertezas econômico-financeiras e políticas da Venezuela levantavam sérios temores nos investidores estrangeiros. ${ }^{287}$

A aproximação das eleições causava grandes expectativas nos observadores brasileiros. O ex-presidente Rafael Caldera, que governou o país entre 1969 e 1974 pelo Copei, liderava as pesquisas de opinião. No começo do ano, desligou-se desse partido, do qual fora fundador, para concorrer novamente à Presidência. Em torno de sua candidatura formouse uma aliança de pequenos partidos, que incluíam dissidentes do Copei (democrata-cristão), o partido liberal-conservador Movimento de Integridade Nacional (MIN) e o esquerdista Movimento ao Socialismo (MAS). A heterogeneidade dessa aliança fez com que ela fosse apelidada "chiripero" (vespeiro). ${ }^{288}$ A estratégia eleitoral de Caldera consistia em se distanciar da política neoliberal, marcando posição contrária em relação ao governo anterior de Carlos Andrés Pérez e aos demais candidatos, do Copei, da Ação Democrática e mesmo do partido esquerdista da Causa Radical. $\mathrm{O}$ discurso de Caldera gerou preocupações na imprensa brasileira, então já abertamente favorável às políticas neoliberais. ${ }^{289}$

\footnotetext{
286 Telegrama $n^{\circ}$ 649, 16/11/1993. De Clodoaldo Hugueney Filho, Embaixador do Brasil em Caracas, ao Ministério de Relações Exteriores. Ano 1993 Telegramas Recebidos Caixa 7.

287 Telegrama $\mathrm{n}^{\circ}$ 658, 17/11/1993. De Clodoaldo Hugueney Filho, Embaixador do Brasil em Caracas, ao Ministério de Relações Exteriores. Ano 1993 Telegramas Recebidos Caixa 7.

288 Jornal do Brasil, 05/12/1993.

289 Dentre todos os jornais que cobriram as eleições, nenhum adotou linha editorial favorável à revisão da estratégia neoliberal de superação da crise. Os exemplos da referida preocupação com o abandono dessa estratégia podem ser encontrados em: Folha de S. Paulo, 28/11/1993; Jornal do Brasil, 05/12/1993; O Globo, 05/12/1993; O Estado de S. Paulo, 05/12/1993; Correio Braziliense, 06/12/1993.
} 
Marlise Ilhesca, correspondente do Jornal do Brasil em Caracas, acompanhou a caravana de Rafael Caldera durante a campanha e entrevistou o candidato procurando saber quais eram suas expectativas sobre as relações entre Venezuela e Brasil. O candidato garantiu que priorizaria o tratamento das fronteiras e a firmou:

Quando estive no Brasil recentemente, me dei conta que pela primeira vez ambos os países perceberam que têm uma extensa fronteira que supõe a obrigação de uma política comum de desenvolvimento sócio-econômico. Assim sendo, acredito que o Codesur (Programa Conquista do Sul) deva ser reativado, mas, de uma forma atualizada, que leve em conta a ideia do desenvolvimento sustentado proclamado pelas Nações Unidas. Eu integro uma comissão conjunta do Banco Interamericano de Desenvolvimento, Programa das Nações Unidas para a América Latina e Tratado de Cooperação Amazônica para realizar um relatório sobre a Amazônia. Estou convencido de que é indispensável para preservar a região. Evidentemente, não se pode abandonar estas terras para a invasão dos irresponsáveis que depredam os recursos naturais e contribuem para o genocídio das tribos indígenas.

A seguir, completou:

Nunca ocorreu qualquer incidente violento entre os dois países. Entretanto, sempre pareceu que estávamos de costas um para o outro. Vocês virados para o sul e nós para o norte. Agora nos damos conta de que temos que olhar para nossa fronteira comum e parto do princípio de que qualquer esforço que o Brasil faça, nesta área, o faz com boas intenções. ${ }^{290}$

Após sua vitória nas eleições, Rafael Caldera matizou suas críticas ao neoliberalismo argumentando que não poderia trocar uma ortodoxia (neoliberal) por outra, mas se comprometeu a analisar "caso a caso" o que deveria ser mudado. Anunciou também a retomada de seu projeto de desenvolvimento da região sul da Venezuela, afastada dos grandes centros urbanos e próxima à fronteira com o Brasil, tal como havia dito a Marlise Ilhesca. $\mathrm{O}$ principal assessor econômico de Rafael Caldera, Julio Sosa Rodríguez, reafirmou o compromisso do novo governo com as negociações da dívida externa que haviam sido feitas até então. $^{291}$

A cerimônia de posse de Rafael Caldera aconteceu no dia 2 de fevereiro de 1994 e contrastou com a cerimônia pomposa de Carlos Andrés Pérez, realizada cinco anos antes: sequer foram convidados chefes de Estado. O novo presidente prometeu continuar com as privatizações e com a redução dos gastos do governo.

\footnotetext{
290 Jornal do Brasil, 05/12/1993.

${ }^{291}$ Telegramas $n^{\circ}$ 748, 06/12/1993, de Clodoaldo Hugueney Filho, Embaixador do Brasil em Caracas e n 781, 17/12/1993, de Piragibe, Ministro Conselheiro, ao Ministério de Relações Exteriores. Ano 1993 Telegramas Recebidos Caixa 7.
} 
O contexto político em que ocorreu sua posse era muito delicado porque o presidente governaria sem a adesão explícita de nenhum dos dois grandes partidos que haviam dividido o poder desde 1958. A crise na economia continuava em razão da retomada de investimentos e empréstimos a partir da adesão ao Plano Brady; além disso, em janeiro de 1994, estourou uma crise bancária que se estendeu por todo aquele ano, provocando a falência de diversos bancos comerciais e exigindo a utilização dos já escassos recursos do governo. ${ }^{292}$

Pouco tempo após a cerimônia de posse de Rafael Caldera, foi realizado o encontro que Mônica Loss considerou a "o início de uma nova fase nas relações entre o Brasil e a Venezuela". ${ }^{293}$ O presidente brasileiro, Itamar Franco, encontrou-se com Caldera em sua residência de verão, chamada La Guzmania e localizada em Macuto, região da grande Caracas, no dia 4 de março. Esse encontro permitiu a concretização de muitas negociações que vinham sendo gestadas e gerou documentos importantes para o estabelecimento das bases para a futura institucionalização dos trabalhos de cooperação que tiveram início nos anos seguintes. Os documentos mais destacados desse encontro foram o Protocolo da Guzmania e o Comunicado Conjunto.

O texto do Protocolo reconhecia a conveniência de se realizar reuniões presidenciais com maior frequência do que vinha acontecendo até ali já que, nos dois anos anteriores, não ocorreram encontros desse tipo. Também destacou "a coincidência de propósitos e objetivos sobre temas bilaterais e de caráter regional e mundial" entre os dois países. A partir do Protocolo, os presidentes se declararam comprometidos em priorizar as relações bilaterais e elevá-las a uma "nova dimensão", o que foi parcialmente obtido porque o documento, a diferença de outros assinados anteriormente no âmbito das relações bilaterais, criou um novo mecanismo para a realização dessas aspirações. Assim foi criada uma Comissão Binacional de Alto Nível (COBAN), que seria presidida pelos ministros das Relações Exteriores de ambos países e integrada ainda por outros ministros cujos trabalhos pudessem contribuir para a concretização dos objetivos de integração. ${ }^{294}$

No Comunicado Conjunto, os presidentes anunciaram, também, a realização de uma segunda Reunião do Mecanismo de Consulta Política, “com a brevidade possível”. Como o Acordo de Complementação Econômica não havia ainda sido concluído, os presidentes se

\footnotetext{
292 Gazeta Mercantil, 31/01/1994; Correio Braziliense, 03/02/1994.

${ }^{293}$ LOSS, op. cit., p. 82.

${ }^{294}$ Protocolo da Guzmania, publicado em Libro Amarillo correspondente ao ano de 1994, p. 650-651.
} 
comprometeram a instruir as instâncias gerenciadoras do comércio exterior em seus países a apressar esse trabalho. A proposta brasileira de criação da ALCSA também foi mencionada com a indicação de que deveria ser objeto de maiores estudos por ambas as partes, o que significava uma maneira polida das autoridades venezuelanas indicarem que não se consideravam prontas para dar prioridade a esse projeto. Novamente foram retomadas as negociações para maior cooperação entre as estatais petrolíferas, PDVSA e Petrobras, o que significaria a ampliação das compras brasileiras de petróleo venezuelano.

Quanto à região fronteiriça, o Comunicado estabeleceu um conjunto de metas ambiciosas, que podem ser sintetizadas como proposta de transformação de uma área pouco habitada e monitorada em "um espaço de desenvolvimento e integração". Para realizar esse objetivo, os presidentes reconheceram a importância de uma agenda prática, que contava com seis pontos essenciais: a pavimentação da estrada BR-174; a compra de energia venezuelana pelo Brasil, para ser utilizada em Roraima e Amazonas; o estudo da navegabilidade das bacias do Orenoco e do Amazonas; o empreendimento de iniciativas conjuntas no setor de mineração, envolvendo as estatais CVG e CVRD, mas também empresas privadas; a cooperação no setor siderúrgico, envolvendo novamente a brasileira CVRD e a empresa estatal venezuelana Siderúrgica do Orenoco (SIDOR); e o desenvolvimento do turismo ecológico na região.

Para tentar impedir ações consideradas nocivas na região - narcotráfico e mineração ilegal -, os presidentes se comprome teram a reforçar a cooperação em matéria de inteligência, com a participação da Venezuela no Sistema de Vigilância da Amazônia (SIVAM) do go verno brasileiro.

Nesse Comunicado de cooperação bilateral, os representantes dos dois países se manifestaram a respeito do contexto político da América Central, celebrando a consolidação da democracia, mas ressaltando a necessidade de serem implementadas políticas de desenvolvimento econômico e de justiça social. Também manifestaram expectativa de que pudessem cooperar na Cúpula Hemisférica, que aconteceria em Miami, nos Estados Unidos, ainda naquele ano e que versaria sobre as tratativas para implementação de uma área de livre comércio de alcance continental. ${ }^{295}$

\footnotetext{
${ }^{295}$ Libro Amarillo correspondente ao ano de 1994, p. 651-655.
} 


\section{ADENSAMENTO DAS RELAÇÕES BILATERAIS A PARTIR DE NOVAS BASES (1994-1998)}

A institucionalização dos trabalhos a partir do encontro da Guzmania, realizado entre os presidentes Itamar Franco e Rafael Caldera em março de 1994, teve como consequências forte aceleração do processo de aproximação política entre os dois países, ainda que deva ser compreendido em um contexto de iniciativas diplomáticas que remonta à década anterior. Mas esse fato novo na política internacional não pode impedir a deterioração econômica e política interna da Venezuela. A previsão de entrada de recursos com a venda do petróleo era de US\$ 9 bilhões para aquele ano de 1994, contra US\$ 20 bilhões recebidos nos anos 1980 e 1981. O processo de liberalização financeira iniciado por Carlos Andrés Pérez em 1989 acabou por aprofundar a desestabilização financeira nos anos seguintes. Em 1992, o governo se viu obrigado a elevar as taxas de juros, mas essa ação levou a que muitos devedores não pudessem mais pagar suas dívidas, pressionando a posição dos bancos. O resultado foi que, a princípios de 1994, no mesmo contexto em que Itamar Franco e Rafael Caldera se encontraram na Venezuela, aquele país enfrentava grave crise bancária. ${ }^{296}$

Para responder a essa situação, Rafael Caldera encaminhou ao Congresso o Plano Sosa, nomeado a partir do nome de seu Ministro da Fazenda, Julio Sosa Rodríguez.

\subsection{PRIMEIROS RESULTADOS DO ENCONTRO DA GUZMANIA}

O Plano buscava capitalizar o Estado a partir da elevação da carga tributária e do corte de gastos públicos. Dirigindo-se ao Ministério das Relações Exteriores, o Embaixador do Brasil comentou que o Plano tinha boas chances de lograr os objetivos do governo: "pode não representar a melhor resposta, mas é seguramente a resposta possível aos problemas da

\footnotetext{
${ }^{296}$ Jornal do Brasil, 30/01/1994.

Gazeta Mercantil, 31/01/1994.
} 
Venezuela, não tanto do ponto de vista da lógica econômica, mas certamente da ótica da sobrevivência política do governo". ${ }^{297}$

No âmbito político, Caldera procurou diminuir as tensões, anistiando o líder dos militares rebelados, Hugo Chávez, preso desde 1992. Já em seus primeiros dias de liberdade. Chávez foi recebido por muitos simpatizantes e, desligado das Forças Armadas, pode iniciar uma carreira política que logo o transformou no principal nome da oposição venezuelana. Os processos judiciais contra ex-membros do governo de Carlos Andrés Pérez continuavam, e muitos deles já se estavam vivendo no exterior, como se fossem refugiados ou foragidos, a depender de quem avaliasse a situação. Tal era o caso do ex-chanceler Reinaldo Figueredo, que vivia na Suíça. O ex-presidente, porém, não pode evitar sua prisão, decretada e executada no dia 18 de maio, em razão das acusações de corrupção que levaram ao seu afastamento da presidência, menos de um ano antes. ${ }^{298}$

Cabe frisar que, mesmo o cenário complicado da economia e da política venezuelanas não impediu que as relações entre os dois países assumissem, a partir daquele ano, uma dinâmica própria. Em contraste com os anos de 1992 e 1993, quando a desestabilização nos dois países levou a uma desaceleração dos encontros bilaterais, o encontro da Guzmania criou uma base sólida e duradoura a partir de reuniões que respeitavam, rigorosamente, um cronograma pré-estabelecido. A maior parte dessas reuniões aconteceu com a presença de grupos de trabalho compostos por funcionários e pessoal técnico, que continuavam as negociações de cooperação a despeito da persistência da crise.

A realização da segunda reunião do Mecanismo Político de Consulta, na cidade de Caracas, durante visita do secretário-geral do Ministério das Relações Exteriores, Roberto Abdenur, entre os dias 3 e 4 de maio, demonstra que os acordos bilaterais tinham autonomia para atuar independentemente da crise. ${ }^{299}$ O objetivo dessa reunião era dar seguimento à resolução expressa pelos dois presidentes no encontro da Guzmania para que fosse criada uma base institucional sólida para assegurar as relações entre os dois países. Para esse fim, os chefes das delegações decidiram constituir seis grupos de trabalho, versando sobre os seguintes temas: comércio e integração; energia; transporte e comunicações; mineração e

297 Telegrama $\mathrm{n}^{\circ}$ 202, 12/03/1994. De Clodoaldo Hugueney Filho, Embaixador do Brasil em Caracas, ao Ministério de Relações Exteriores. Ano 1994 Telegramas Recebidos Caixa 11.

298 Jornal de Brasília, 27/03/1994. Jornal do Brasil, 12/04/1994. Jornal do Brasil, 28/04/1994. Gazeta Mercantil, 19/05/1994. Folha de S. Paulo, 19/05/1994.

${ }^{299}$ Libro Amarillo referente ao ano 1994, p. 655. 
siderurgia; meio ambiente; e desenvolvimento fronteiriço. Coube ao governo de cada país indicar, posteriormente, os funcionários que comporiam os grupos. Foi decidida ainda a convocação de uma Comissão Mista de Cooperação Cultural, que se reuniu nos dias 19 e 20 daquele mesmo mês, com objetivo de elaborar um programa binacional de cooperação no setor. Os chefes de delegação presentes naquela reunião ficaram encarregados de atribuir à Comissão Mista de Repressão ao Tráfico, formada a partir do acordo de 1977, a responsabilidade pela formulação de propostas de ações conjuntas para combater o narcotráfico. Por fim, a delegação venezuelana expressou receptividade à proposta de formação da ALCSA, encampada pelo governo brasileiro, destacando que constituía um "paso importante para la ampliación del comercio entre los países de la región y para auspiciar una futura integración hemisférica". 300

No dia 13 de maio aconteceu a primeira reunião do grupo de trabalho sobre meio ambiente encarregado de traçar iniciativas conjuntas como desenvolvimento do turismo ecológico e de pesquisa sobre biodiversidade e cooperação para recuperar as áreas desmatadas pela mineração ilegal. No contexto no qual o grupo foi formado, o Ministro venezuelano de Meio Ambiente visitou o Brasil e teve encontros com autoridades brasileiras durante uma semana. $^{301}$

Esses encontros do mês de maio marcaram uma série de frequentes contatos diplomáticos que visavam implementar as decisões tomadas em La Guzmania. No âmbito deste trabalho não cabe uma descrição pormenorizada do funcionamento dos grupos de trabalho e suas reuniões, mas é importante contextualizar os momentos nos quais ele foi formado, bem como o tema central a ser abordado e os avanços da discussão que ocorreu em cada um deles. Por esta razão, a narrativa que se segue busca intercalar referências às frequentes reuniões oficiais com a interpretação de diplomatas e jornalistas sobre outros aspectos das relações bilaterais. A recorrente citação de reuniões, datas e acordos busca demonstrar de que maneira essa nova etapa das relações bilaterais contrastou com as fases anteriores, em que os encontros se realizaram de forma menos sistemática.

\footnotetext{
${ }^{300}$ Libro Amarillo referente ao ano 1994, p. 658. A Comissão de Cooperação Cultural foi uma iniciativa que visava envolver os governos nacionais mais ativamente no fomento desse tipo de relações, em face das dificuldades que o Embaixador brasileiro vinha encontrando para obter patrocínio de empresas, mesmo estatais, para eventos desse tipo. Telegrama no 412, 13/05/1994. De Clodoaldo Hugueney Filho, Embaixador do Brasil em Caracas, ao Ministério de Relações Exteriores. Ano 1994 Telegramas Recebidos Caixa 11.

${ }^{301}$ Libro Amarillo referente ao ano 1994, p. 390.
} 
A formação dos grupos de trabalho, embora significasse a consolidação de uma proposta longamente discutida sobre a necessidade de se conferir maior institucionalidade à cooperação, não foi objeto de atenção nos periódicos brasileiros. A atuação dos grupos frequentemente se restringiu a assuntos predominantemente técnicos, de escasso interesse para um público leitor mais amplo. Naqueles dias, a imprensa brasileira deu grande destaque à prisão de Carlos Andrés Pérez, noticiando o acontecimento a partir de uma perspectiva similar à que orientara as reportagens produzidas em anos anteriores. Essa continuidade consistia na comparação entre a dinâmica política brasileira e a venezuelana.

O Jornal do Brasil publicou editorial considerando que a prisão de Perez encerrava "um longo período de demagogia populista", caracterizado pelo fato de que os políticos diziam uma coisa, mas, nos bastidores, faziam outra. Mas acrescentavam a seguinte frase: "A Venezuela, pelo menos, demonstra que combate corruptos e demagogos com seriedade, doa a quem doer". ${ }^{302}$ Neste último comentário fica subentendida a comparação com a política brasileira.

O Correio Braziliense foi mais explícito na comparação entre o Brasil e a Venezuela. Em seu editorial, encontramos a seguinte afirmação:

O episódio guarda uma lição muito importante para o Brasil em particular, onde a regra é a morosidade dos julgamentos e a impunidade dos culpados. Basta ver que, na Venezuela, o processo contra Pérez levou apenas um ano e dois meses para alcançar a sentença definitiva. Aqui, processo em tudo semelhante não tem sequer previsão quanto ao seu desfecho. ${ }^{303}$

O comentário não se referia especificamente ao caso de Fernando Collor de Mello, que teve os seus direitos políticos cassados por oito anos em decorrência das acusações de corrupção. Antes, o texto refletia uma percepção mais difusa sobre o nível geral de corrupção e impunidade da política brasileira.

Ainda em maio, a embaixada do Brasil em Caracas começou a publicar o "Boletim Informativo Brasil", sem periodicidade definida, condicionada ao surgimento de "algum elemento novo de informação relevante" sobre a política e a economia do Brasil. O Boletim buscava apresentar as noticias ou versões oferecidas pelas agencias internacionais que fossem mais favoráveis aos interesses do governo brasileiro sobre o julgamento dos presidentes; esse material era direcionando aos órgãos de imprensa locais e "outros setores considerados

\footnotetext{
${ }^{302}$ Folha de S. Paulo, 19/05/1994. Jornal da Tarde, 19/05/1994. O Estado de S. Paulo, 19/05/1994.

${ }^{303}$ Correio Braziliense, 20/05/1994.
} 
relevantes". Em muitas situações, o objetivo consistia em contrapor o conteúdo das notícias veiculadas pelas agências internacionais à imprensa venezuelana, única fonte à qual tinham acesso os jornais do país que não contavam com a presença de correspondentes no Brasil.

Cabe mencionar outras comparações feitas pelos periódicos venezuelanos entre a situação venezuelana e brasileira. No mês de julho, o diário venezuelano Economía Hoy baseou-se em texto fornecido pela embaixada brasileira para noticiar o plano de estabilização econômica daquele país. ${ }^{304}$

Em 29 de junho, o Correio Brazilien se publicou editorial ignorando, completamente, a responsabilidade da desregulamentação bancária sobre a crise econômica venezuelana e fez referência à lição que os brasileiros deveriam tirar daquela crise. Ou seja, a de que a modernização do Estado (entendida nos moldes do modelo neoliberal) não podia ser contaminada pela voracidade oligárquica e nem obstaculizada pela "demagogia de feição marxista". 305

Naquele mesmo mês, a diplomacia dos dois países continuou empenhada no estabelecimento dos grupos de trabalho. No dia 6, instalou-se, formalmente, o grupo de trabalho sobre comércio e integração, cuja finalidade era conduzir as negociações para cooperação bilateral relativa ao Acordo de Complementação Econômica, à Área de Livre Comércio Sul-Americana e a outros temas relacionados à integração latino-americana. $\mathrm{O}$ primeiro resultado concreto da atuação desse grupo de trabalho foi a assinatura do ACE no dia 14 de julho em Caracas. ${ }^{306}$

O grupo de trabalho sobre cooperação energética fora instalado no dia 8 de junho. $\mathrm{O}$ grupo se concentrou na avaliação de formas capazes de aumentar as vendas de petróleo da Venezuela para o Brasil e no incentivo a iniciativas conjuntas da Petrobrás e da PDVSA para realizar pesquisas que aumentassem o aproveitamento de petróleo pesado. Foi no âmbito das reuniões desse grupo que a Venezuela e o Brasil negociaram a venda de um novo combustível venezuelano para usinas termoelétricas brasileiras, chamado Orimulsão. Por fim, a esse grupo de trabalho ficou a responsabilidade de estabelecer negociações para construção de uma linha

\footnotetext{
304 Telegrama $n^{\circ}$ 646, 03/08/1994. De Clodoaldo Hugueney Filho, Embaixador do Brasil em Caracas, ao Ministério de Relações Exteriores. Ano 1994 Telegramas Recebidos Caixa 11.

305 Correio Braziliense, 29/06/1994.

${ }^{306}$ Libro Amarillo referente ao ano 1994, p. 174.
} 
de transmissão de eletricidade da usina venezuelana de Guri até Manaus, a partir da cooperação entre as estatais Eletrobrás e Edelca. ${ }^{307}$

O grupo de trabalho sobre transporte e comunicações foi instalado no dia $1^{\circ}$ de julho e centralizou as tratativas para pavimentação da estrada BR-174, ligando a fronteira entre os dois países até Manaus. Tratava-se de uma antiga promessa, que remontava ao tempo dos governos militares, mas não cumprida até então. Também foram realizadas através desse grupo as negociações para a celebração de um acordo de transporte terrestre e para a condução de pesquisas conjuntas sobre a viabilidade da navegação das bacias do Orenoco e do Amazonas. ${ }^{308}$ Tal iniciativa representava uma resposta à recomendação que o embaixador Clodoaldo Hugueney fizera às autoridades brasileiras, em telegrama enviado no mês de abril, quando considerou que o aumento do volume de transporte de mercadorias por via terrestre entre os dois países estabelecia a demanda por uma nova regulamentação dessa modalidade de comércio. $^{309}$

No dia 20 de julho foi instalado o grupo de trabalho sobre mineração e siderurgia. Dentre as atribuições desse grupo estavam o desenvolvimento de projetos a serem realizados conjuntamente pelas estatais Companhia Vale do Rio Doce e Corporación Venezolana de Guayana. O grupo também foi incumbido de articular a pesquisa conjunta de tecnologias de mineração ambientalmente sustentáveis. ${ }^{310}$ Gradualmente a agenda bilateral incorporava novas temáticas da política internacional, como era o caso da preocupação com o meio ambiente.

O Diretor Geral do Ministério das Relações Exteriores da Venezuela, Roy Chaderton Matos, visitou o Brasil entre os dias 21 e 22 de julho, para chefiar a delegação venezuelana na III Reunião do Mecanismo Político de Consulta, em Brasília. Uma das novidades desse encontro foi que as delegações procederam à análise pormenorizada da conjuntura nacional de cada um dos dois países. Também as delegações coincidiram em promover em seus países a realização de feiras de negócios que aproximassem o empresariado. Durante a reunião foram

\footnotetext{
${ }^{307}$ Libro Amarillo referente ao ano 1994, p. 388.

${ }^{308}$ Libro Amarillo referente ao ano 1994, p. 388.

309 Telegrama $n^{\circ}$ 324, 15/04/1994. De Clodoaldo Hugueney Filho, Embaixador do Brasil em Caracas, ao Ministério de Relações Exteriores. Ano 1994 Telegramas Recebidos Caixa 11.

${ }^{310}$ Libro Amarillo referente ao ano 1994, p. 389.
} 
analisados os resultados dos encontros dos grupos de trabalho e se concluiu que esse formato de cooperação era capaz de fomentar um processo "contínuo e dinâmico" de cooperação. ${ }^{311}$

Na semana seguinte ( 28 e 29 de julho), se reuniu em Caracas a COBAN, com a presença dos Ministros de Relações Exteriores e na qual os chanceleres aprovaram as recomendações dos grupos de trabalho e se congratularam pela conclusão das obras de pavimentação da estrada BR-174 no trecho entre a fronteira e a cidade de Boa Vista. Expres saram, conjuntamente, o interesse dos governos dos dois países em atrair investimentos da iniciativa privada para a pavimentação do trecho restante, entre Boa Vista e Manaus. No que se refere às tratativas do grupo de trabalho sobre o meio ambiente, os chanceleres concordaram em criar rotas turísticas ecológicas entre os dois países e intensificar a troca de informações e experiências em matéria de biodiversidade. Daquela reunião resultaram ainda um Aide-memoire sobre temas multilaterais de interesse comum, um Memorando de Entendimento sobre cooperação para formação de pessoal diplomático e o primeiro protocolo adicional ao Acordo de Complementação Econômica, que objetivava "promover a expansão e diversificação do comércio, estimular o desenvolvimento de atividades conjuntas de investimento e auspiciar mecanismos de promoção de investimentos entre ambos os países". 312

O conteúdo do Aide-memoire explicitou a contextualização das iniciativas de aproximação política em um quadro mais geral de liberalização econômica levada a cabo nos dois países. Também foi registrada, nesse documento, a insistência do chanceler brasileiro, Celso Amorim, para que fossem iniciadas consultas e trocas de informações visando à conformação da ALCSA, em um prazo máximo de dez anos. O chanceler venezuelano agradeceu a oferta de Amorim e aceitou iniciar o processo de consultas. A Venezuela, em contrapartida, solicitou ao Brasil um tratamento tarifário preferencial para as suas exportações de petróleo e derivados, ao que o chanceler brasileiro respondeu que levaria o assunto ao conhecimento das autoridades competentes. ${ }^{313}$

\footnotetext{
${ }^{311}$ Libro Amarillo referente ao ano 1994, p. 674.

${ }^{312}$ Libro Amarillo referente ao ano 1994, p. 367.

313 Telegrama no 705, 17/08/1994. De Clodoaldo Hugueney Filho, Embaixador do Brasil em Caracas, ao Ministério de Relações Exteriores. Ano 1994 Telegramas Recebidos Caixa 11.
} 


\subsubsection{O plano Real e suas consequências para as relações com a Venezuela}

Os meses de maio, junho e julho também foram marcados pela aplicação de uma nova política econômica no Brasil, inspirada pelo ex-Chanceler e então Ministro da Fazenda, Fernando Henrique Cardoso. O Plano Real, como foi chamado, consistiu na troca da moeda brasileira, que deixava de ser o Cruzeiro Real para chamar-se apenas Real, a partir de julho. A nova taxa de câmbio foi mantida valorizada para facilitar as importações, aumentando a oferta de produtos no mercado brasileiro como forma de forçar a diminuição dos preços e, consequentemente, da taxa de inflação. Para reforçar essa estratégia, a liberalização do comércio exterior continuou, mediante a diminuição das tarifas. Ademais, procedeu-se à diminuição dos gastos do governo, por um lado, e à retomada das privatizações, de outro lado, para gerar receitas e reduzir os gastos com as estatais. O Plano foi bem sucedido em seu objetivo principal que era conter a inflação, além de gerar euforia pelo barateamento dos produtos importados em decorrência da valorização do câmbio.

Até 1999, quando o governo brasileiro se viu forçado a desvalorizar a moeda para conter déficits, o Plano Real foi considerado uma referência de sucesso na aplicação de várias premissas neoliberais. Ele possibilitou a retomada dos empréstimos e investimentos no Brasil, marcando assim a superação da crise de financiamento causada pelas dificuldades de pagamento da dívida externa. No entanto, é importante notar que o mecanismo de alívio da crise representou na realidade uma ampliação daquela dívida, cujos pagamentos continuara m a ser feitos mediante a contratação de novos empréstimos. ${ }^{314}$

Daquele momento em diante, o Brasil se tornou um modelo de superação da crise, reforçando sua capacidade de atração diplomática mediante o assessoramento das autoridades venezuelanas para a reforma de sua economia. Os grupos de trabalho continuaram se reunindo: o que era responsável pelo tema do desenvolvimento fronteiriço se reuniu pela primeira vez em Puerto Ordaz, no dia 25 de agosto, com a presença do ministro Burelli Rivas, atestando a importância conferida pelos venezuelanos às atividades dos grupos de trabalho. Os temas que nortearam os trabalhos desse grupo versaram sobre o comércio na região de

\footnotetext{
${ }^{314}$ CARDOSO, op. cit.

GOMES, Luiz Marcos. Os homens do Presidente. São Pau lo: Viramundo, 2000.
} 
fronteira, o monitoramento das atividades de mineradores ilegais na região e o compartilhamento da experiência brasileira de zoneamento econômico e ecológico. Mais especificamente, os venezuelanos manifestaram mais uma vez o seu interesse em compartilhar com o Brasil as experiências de tecnologia para vigilância da Amazônia. ${ }^{315}$

Ainda naquele mês, a Cervejaria Brahma inaugurou, no dia 12, sua primeira fábrica na Venezuela, na cidade de Barquisimeto, a 300 quilômetros de Caracas. A inauguração contou com a presença de personalidades importantes como o Ministro do Fomento e Comércio Exterior, e do Presidente do Congresso Nacional. Em relato feito pelo Embaixador para o Ministério das Relações Exteriores, o evento foi avaliado de maneira bastante positiva, sobretudo em relação ao impacto que se poderia esperar desse tipo de negócio:

Para o Brasil, a vinda da Brahma para a Vene zuela reveste-se de importância por ser
o primeiro investimento brasileiro de peso e estar sendo feito por uma empresa do
porte e tradição da Brahma, capaz de criar uma imagempositiva que facilitará outros
investimentos. As exportações para o Caribe, antes feitas a partir do Brasil, e a
possibilidade de exportação para a Colômbia são também fatores capazes de
viabilizar e consolidar o empreendimento. 316

Em setembro Rafael Caldera fez uma visita oficial ao Brasil, onde copresidiu as comemorações pela Independência na condição de convidado de honra. ${ }^{317} \mathrm{O}$ presidente venezuelano cumpriu extensa agenda entre os dias 6 e 10 daquele mês e recebeu convite do presidente Itamar Franco para que a Venezuela se associasse ao Mercosul. Em um movimento pouco usual, Rafael Caldera se entrevistou com os dois principais candidatos à Presidência da República, Fernando Henrique Cardoso e Luiz Inácio Lula da Silva. Esse encontro foi entendido na Venezuela como uma sinalização de um consenso entre os brasileiros em relação à importância da aproximação do Brasil com o país vizinho. ${ }^{318}$

A presença de Marcel Granier, diretor-presidente do O Diário de Caracas, na comitiva que acompanhou o presidente Rafael Caldera na viagem ao Brasil, contribuiu muito para a disseminação dessa interpretação sobre as benesses das relações bilaterais. O Diario era um dos maiores jornais venezuelanos à época e se destacava por ser o mais favorável, dentre os

\footnotetext{
315 Libro Amarillo referente ao ano 1994, p. 390.

316 Telegrama $n^{\circ}$ 714, 19/08/1994. De Clodoaldo Hugueney Filho, Embaixador do Brasil em Caracas, ao Ministério de Relações Exteriores. Ano 1994 Telegramas Recebidos Caixa 11.

${ }^{317}$ O convite a que Rafael Caldera copatrocinasse as comemorações de 7 de setembro de 1994 só teve como antecedente a participação do presidente argentino, na mes ma condição, no ano anterior. EMBAIXADA DA VENEZUELA NO BRASIL, Abriendo caminos para la historia: los viajes del presidente Caldera al Brasil. Caracas: Ed itorial Panapo, 1997, p. 13.

${ }^{318}$ MENDIBLE ZURITA, op. cit., p. 198.
} 
periódicos de maior circulação no país, à política de aproximação com o Brasil pro movida pelo Presidente venezuelano. Como Granier também era dirigente da Radio Caracas TV, a segunda maior rede de televisão do país, sua presença na comitiva foi muito importante para a divulgação da visita. Essa divulgação contribuiu para a aceitação da opinião pública em relação à importância da aproximação com o país vizinho. ${ }^{319}$

$\mathrm{Na}$ entrevista coletiva que concedeu à imprensa, Caldera afirmou crer que as relações entre os dois países estavam no ponto mais alto da história e com perspectivas de melhorar ainda mais. Também se referiu ao problema da atuação dos garimpeiros brasileiros na região de fronteira, procurando minimizar esse problema, alegando que não eram apenas garimpeiros brasileiros que atuavam na fronteira venezuelana, mas sim de várias nacionalidades. Além disso, explicitou a maneira pela qual esperava que a questão fosse definitivamente superada, ao afirmar que se deveriam explorar as riquezas minerais da região com atividade industrial tecnologicamente capacitada, mas "que respete y garantice la ecología ambiental y la ecología humana, con la protección adecuada a las etnias indígenas que viven en la región". 320

Ainda por ocasião da entrevista coletiva, Caldera declarou seu distanciamento da ideologia neoliberal, salientando:

Está demostrado que las medidas del ajuste económico que se han adoptado en las corrientes de la globalización, por si solas, no resuelven el problema de la pobreza, sino que más bien, los países que han aplicado estas medidas de ajuste, el porcentaje de personas, de población, que vive en situación de pobreza y más gravemente aún, de pobreza crítica, ha aumentado en todos los países, en vez de haber disminuido, como consecuencia de las medidas de mejoramiento macroeconómico. ${ }^{321}$

Paralelamente à visita presidencial aconteceu a terceira reunião da COBAN. Um dos resultados dessa reunião foi a decisão conjunta de implementar estudos sobre a viabilidade para a criação de linhas aéreas regionais que conectassem o sul da Venezuela com o norte do Brasil. A reunião foi presidida pelos Ministros de Relações Exteriores, que consideraram satisfatório o avanço nas obras de pavimentação da estrada BR-174, cujo trecho entre a fronteira e Boa Vista estava para ser inaugurado. Ficou patente, porém, que nenhum dos dois

\footnotetext{
319 Telegrama $n^{\circ}$ 574, 21/06/1995. De Clodoaldo Hugueney Filho, Embaixador do Brasil em Caracas, ao Ministério de Relações Exteriores. Ano 1995 Dig italizado.

${ }^{320}$ Libro Amarillo referente ao ano 1994, p. 608.

${ }^{321}$ Libro Amarillo referente ao ano 1994, p. 609.
} 
países teria recursos suficientes, nem possibilidade de consegui-los no exterior, para financiar a extensão das obras ao trecho que ligava Boa Vista a Manaus. ${ }^{322}$

Dessa forma, se completou o primeiro ciclo de um modus operandi mais institucionalizado para as relações bilaterais, em comparação com a prática desenvolvida nos anos anteriores. Os grupos de trabalho encaminhavam as negociações específicas de cada área temática, e as delegações que ali se reuniam eram chefiadas por diplomatas e composta por técnicos e representantes da iniciativa privada. Suas deliberações deram origem a recomendações de políticas públicas que eram submetidas à análise das delegações presentes nas reuniões do Mecanismo de Consulta Política, chefiadas pelos Vice-Ministros das Relações Exteriores. Esse Mecanismo, por sua vez, estava subordinado às reuniões da COBAN, cujas delegações eram presididas pelos Ministros das Relações Exteriores. Nessas reuniões, os Ministros avaliavam os relatórios das instâncias inferiores e sugeriam as adequações à política de cooperação que seriam implementadas por ocasião dos encontros presidenciais.

\subsubsection{A diplomacia presidencial a partir da eleição de Fernando Henrique Cardoso}

Em outubro, ocorreram as eleições presidenciais no Brasil, e o ex-Ministro da Fazenda de Itamar Franco, Fernando Henrique Cardoso (PSDB), saiu vitorioso já no primeiro turno, contra o candidato do Partido dos Trabalhadores, Luis Inácio Lula da Silva, crítico do modelo neoliberal. A eleição de Cardoso consolidou a opção brasileira a favor do Consenso de Washington; o novo presidente compôs uma equipe econômica que tinha fortes laços ideológicos e profissionais com os principais bancos e organismos financeiros internacionais. ${ }^{323}$

Por ocasião das eleições no Brasil, o embaixador Clodoaldo Hugueney recebeu cumprimentos do presidente Rafael Caldera e do chanceler Burelli Rivas. Naquela ocasião, foi reiterado o convite para que Fernando Henrique Cardoso visitasse a Venezuela dentro em

\footnotetext{
322 Libro Amarillo referente ao ano 1994, p. 691.

${ }^{323}$ Tais ligações, que remontavam ao te mpo de Sarney, Collor e Itamar Franco, foram detalhadas em GOMES, op. cit.
} 
breve. Em seu relatório a respeito desses contatos com o Presidente venezuelano, o Embaixador comentou sua boa vontade em relação ao Brasil e ao governo recém-eleito:

Estas manifestações e inúmeras outras que tenho recebido de personalidades
políticas e intelectuais venezuelanas refletem o apreço deste país pelo Brasil e a
confiança em um maior estreitamento das relações entre os dois países, o qual se
tornou realidade após o encontro entre os presidentes Itamar Franco e Rafael
Caldera em La Guzmania. A ampla cobertura de imprensa das eleições, sempre
simpática e elogiosa, revela igualmente essa recuperação de nossa presença e
imagem na Venezuela.

No dia 24 de outubro, o grupo de trabalho se reuniu outra vez para discutir as questões referentes ao desenvolvimento fronteiriço a partir da cidade de Boa Vista e, nessa ocasião foi assinada a Ata Constitutiva do Conselho Empresarial Binacional do Norte. Dois dias depois, aconteceu a segunda reunião do grupo de trabalho sobre o meio ambiente, em Caracas, com a participação dos Ministros do Meio Ambiente dos dois países. ${ }^{325}$ Ainda naquele mês, a Venezuela materializou sua aproximação com o Mercosul mediante a assinatura de acordos de complementação econômica com cada um dos países membros daquela organização. ${ }^{326}$

Em dezembro, Fernando Henrique Cardoso compareceu, a convite do presidente Itamar Franco, à Cúpula das Américas, em Miami, na qualidade de presidente eleito. Fez escala na Venezuela, no dia 10, e declarou que o país era um sócio prioritário do Brasil. Reconheceu também os avanços obtidos nos anos anteriores, no que diz respeito às relações bilaterais, e se comprometeu a aprofundar esse processo. Também naquele mês se reuniu pela primeira vez o sétimo grupo de trabalho, para negociar a cooperação em matéria de ciência e tecnologia. ${ }^{327}$

Em discurso anual pronunciado no Congresso venezuelano para prestação de contas do Ministério, o chanceler venezuelano Miguel Ángel Burelli Rivas considerou que o ano de 1994 trouxera avanços nas relações com o Brasil, especialmente através da assinatura do Acordo de Complementação Econômica. Destacou, ainda, o que considerava como objetivos fundamentais para a economia venezuelana: a venda de energia elétrica da usina de Guri a Manaus; o aumento das exportações de petróleo para o Brasil, para que a Venezuela voltasse a ter a importância que tivera como fornecedor desse produto antes do golpe militar de 1964;

\footnotetext{
324 Telegrama $\mathrm{n}^{\text {o }}$ 861, 11/10/1994. De Clodoaldo Hugueney Filho, Embaixador do Brasil em Caracas, ao Ministério de Relações Exteriores. Ano 1994 Telegramas Recebidos Caixa 11.

${ }^{325}$ Libro Amarillo referente ao ano 1994, p. 695.

${ }^{326}$ Libro Amarillo referente ao ano 1994, p. 368.

327 A referência à viagem de Fernando Henrique está em MENDIBLE ZURITA, op. cit., p. 199. A referência ao grupo de trabalho sobre ciência e tecnologia está no Libro Amarillo referente ao ano 1995, p. 497.
} 
o abastecimento dos mercados do norte e nordeste do Brasil com produtos venezuelanos e a participação da Venezuela no sistema brasileiro de vigilância da Amazônia. ${ }^{328}$

Em janeiro, o Governador de Roraima, Neudo Campos, visitou a Venezuela onde foi recebido pelo Embaixador. Nesse encontro, ressaltou que a agenda com aquele país tinha evoluído, nos anos anteriores, de temas negativos como o garimpo e os conflitos em terras indígenas para assuntos mais positivos, como a integração física centrada especialmente nas obras da estrada BR-174 e na transmissão de energia elétrica da Venezuela para Roraima. Especificamente a respeito da estrada, o Embaixador expressou que, mais do que representar "uma saída para outras regiões do mundo", a estrada tinha a finalidade de dinamizar a economia da região fronteiriça, agregando atividades comerciais, de investimentos e de fluxo de pessoas. Consciente da importância dessa integração com a Venezuela, o Governador de Roraima recordou que ela contrastava com as dificuldades de conexão com Manaus, maior centro urbano da região. Por essa razão, solicitou que fossem intensificados os esforços para integrar a Venezuela ao Mercosul, gerando condições para estreitar ainda mais os laços econômicos com Roraima. ${ }^{329}$

Ainda com base nos relatos do Embaixador, é possível discernir uma retomada da política de privatizações na Venezuela, nos primeiros meses de 1995. A PDVSA concretizou acordos de investimentos conjuntos com as empresas estadunidenses Mobil e Chevron. Mas a implementação dos acordos esbarrava na legislação venezuelana, que concedia ao Estado o monopólio das atividades no setor petrolífero. Foram então retomadas no Congresso as discussões para a reforma da legislação, para permitir a associação da estatal venezuelana com empresas estrangeiras. $\mathrm{O}$ assunto interessava ao Brasil porque havia a possibilidade de associar a Petrobras com a PDVSA na exploração de campos de petróleo na Venezuela. Luis Giusti, então Presidente da PDVSA, era um dos mais destacados defensores da chamada "abertura" do setor petroleiro, e se filiava, dessa forma, ao grupo das autoridades venezuelanas favoráveis ao aprofundamento do neoliberalismo no país. Além da reforma do setor petroleiro, a privatização avançava no setor minerador. No dia 15 de março, o Congresso venezuelano aprovou, com votos favoráveis da Convergência (federação de pequenos partidos

\footnotetext{
${ }^{328}$ Libro Amarillo referente ao ano 1994, p. LIX-LX.

329 Telegrama $n^{\circ}$ 23, 13/01/1995. De Clodoaldo Hugueney Filho, Embaixador do Brasil em Caracas, ao Ministério de Relações Exteriores. Ano 1995 Dig italizado.
} 
apoiadores do governo Caldera), da AD, do Copei e do MAS, a privatização das empresas subsidiárias da Corporação Venezuelana de Guayana (CVG). ${ }^{330}$

A segunda reunião do grupo de trabalho sobre ciência e tecnologia aconteceu nos dias 24 e 25 de abril. Na reunião, ficou decidida a realização de consultas trimestrais a respeito do andamento das ações desenvolvidas e das formas de financiamento para o funcionamento do grupo. Por se tratar de dois países de escassa produção científica e tec nológica, ficou acordada a intenção de recorrer conjuntamente aos programas da União Europeia para assistência em matéria tecnológica. Naquela mesma semana teve lugar a terceira reunião do grupo de trabalho sobre desenvolvimento fronteiriço, com a participação de representantes do setor privado. A participação dos empresários possibilitou que fosse celebrada uma reunião do Conselho Empresarial Venezuela-Brasil, de conteúdo pouco substancial. O único resultado prático dessa reunião foi o acordo de cooperação que tinha como objetivo elaborar um regulamento de funcionamento do Conselho. ${ }^{331}$

Entre os dias 15 e 16 de maio, reuniu-se em Caracas o Mecanismo Político de Consulta, que progrediu nas negociações para assinatura de um tratado de livre comércio entre o Mercosul e o Pacto Andino, mecanismo regional de liberalização co mercial do qual a Venezuela era membro. O comércio foi o assunto principal dessa reunião, e as delegações destacaram o fato de que as vendas de petróleo da Venezuela para o Brasil haviam triplicado desde que se intensificaram os encontros bilaterais no ano anterior. Além do comércio, foram revisados os relatórios de atividade dos grupos de trabalho e também foi aprovada a proposta, que deveria ser submetida à Comissão Binacional de Alto Nível, para formação de outros dois grupos de trabalho: sobre telecomunicações e sobre planejamento. Caberia a este último grupo coordenar a troca de informações em matéria de ajustes macroeconômicos. ${ }^{332}$

No dia 17 de maio, o chanceler venezuelano discursou na abertura do seminário Venezuela-Mercosul, realizado na sede do Parlamento Latino-Americano, em São Paulo. O

\footnotetext{
${ }^{330}$ Telegramas $n^{\circ} 102,08 / 02 / 1995 ; n^{\circ} 207$ e 210, 09/03/1995; no 232, 16/03/1995. De Clodoaldo Hugueney Filho, Embaixador do Brasil em Caracas, ao Min is tério de Re lações Exteriores. Ano 1995 Dig italizados.

${ }^{331}$ Sobre o grupo de ciência e tecnologia, ver Libro Amarillo referente ao ano 1995, p. 498.

Estavam presentes na reunião do grupo de trabalho de desenvolvimento fronteiriço, representando o setor privado, o Presidente da Câmara de Comércio Brasil-Venezuela, Laerte Oestreicher; o Diretor Superintendente do Serviço Brasileiro de Apoio às Micro e Pequenas Empresas (SEBRAE), Julio Marcos Mourthé; o Presidente da Federação das Associações Comerciais e Industriais de Roraima, Dorival Coelho Maranhão e um representante da Fedecámaras, Angel García Arzo la.

Libro Amarillo referente ao ano 1995, p. 511.

${ }^{332}$ Libro Amarillo referente ao ano 1995, p. 515.
} 
chanceler atentou, em seu discurso, para a importância central que tinham as relações com o Brasil no processo de aproximação com o Mercosul. Na presença dos Ministros de Relações Exteriores do Brasil, do Paraguai e do Uruguai, afirmou que a Venezuela sempre se destacara por uma vocação à integração latino-americana, mas ela não se pode viabilizar em outra época nas relações com o Brasil: por um lado, devido à presença da selva amazônica que dificultava os contatos e, por outro, devido à orientação eurocêntrica assumida pela diplomacia brasileira. Mas Burelli Rivas entendia que o Brasil, desde a década anterior, havia demonstrado interesse na integração com os países da América Latina, o que possibilitava o inicio de no vas políticas com a Venezuela, não apenas através das relações bilaterais, mas também porque permitia a aproximação da Venezuela com os países do Cone Sul. Após discorrer sobre a importância dos encontros das autoridades que vinham acontecendo, cada vez com maior frequência, o Chanceler venezuelano explicitou os interesses econômicos que envolviam essa nova relação política: "Necesitamos del mercado del norte y del nordeste de Brasil y el norte y el nordeste de Brasil necesitan de nosotros, luego hay una complementación indudable a la cual le estamos haciendo seguimiento". 333

Essa visita foi comentada n' O Estado de S. Paulo, que publicou um editorial intitulado "Venezuela no Mercosul", no dia 20 de maio. O texto chamava a atenção para o fato de que representantes dos dois países deixavam clara a urgência para conseguir um acordo de livre comércio entre a Venezuela e o Mercosul, motivo pelo qual sugeriam que ele fosse assinado já no dia 5 de julho, data de comemoração da independência venezuelana (fato que não ocorreu). O editorial reconheceu ainda que a Venezuela era sempre levada em conta, desde que se iniciaram, já na década anterior, novos esforços integracionistas por representantes da política exterior brasileira. Mais do que isso, o texto expressou o franco apoio daquele jornal às iniciativas bilaterais, fato que não era costumeiro na cobertura midiática até aquele momento:

Sempre que se falava na otimização das complementaridades econômicas do Cone Sul, lembrava-se da necessidade de introduzir no arranjo a Venezuela, como fornecedora de recursos energéticos que daria organicidade à região integrada. A contigüidade de território para os sócios no empreendimento comunitário, no entanto, foi a condição de facilidade para a criação do Mercosul que determinou o arquivamento da carta venezuelana. (...) A aproximação da Venezuela do Brasil e do Mercosul é rentável, política e economicamente, para todos. Para o conjunto,

\footnotetext{
${ }^{333}$ Libro Amarillo referente ao ano 1995, p. 471.
} 
crescem as oportunidades econômicas. Para o Brasil e a Venezuela só há vantagens na vivificação da fronteira. ${ }^{334}$

Em junho, foi realizada a quarta reunião da Comissão Binacional de Alto Nível (COBAN), a reunião do Conselho de Integração Empresarial e a terceira reunião do grupo de trabalho sobre meio ambiente. A reunião da COBAN, maior instância de cooperação, teve lugar entre os dias 12 e 13 em Brasília e foi presidida pelos chanceleres dos dois países (do lado brasileiro, também participaram os Ministros da Justiça e de Minas e Energia). Além de repassar os temas que haviam sido tratados no âmbito dos grupos de trabalho, os chanceleres aprovaram a recomendação emanada da reunião do Mecanismo Político de Consulta para que fossem instituídos grupos de trabalho sobre telecomunicações e planejamento.

O Chanceler venezuelano teve agenda intensa no Brasil: reuniu-se com o presidente Fernando Henrique Cardoso, com o Presidente da Comissão de Relações Exteriores do Senado, senador José Sarney e com o Presidente do Superior Tribunal Federal, Sepúlveda Pertence. Igualmente importante foi a sua participação na inauguração do Seminário sobre Relações Brasil-Venezuela. ${ }^{335} \mathrm{O}$ evento constituiu um fato inédito porque reuniu representantes de diversos setores sociais, como acadêmicos e empresários, além de autoridades de governo.

Como já foi mencionado, o Seminário aconteceu em Brasília durante a visita do chanceler venezuelano ao Brasil, por ocasião da quarta reunião da COBAN. As diversas palestras, discursos e intervenções que ocorreram nesse evento foram compiladas e publicadas em livro, que passou a constituir a principal fonte sobre o evento. Cabe mencionar o discurso inaugural do chanceler, no qual apresentou sua interpretação sobre a crise venezuelana, afirmando que se tratava de uma crise de cultura política e de percepção de vida, de um povo pobre que acreditou que era rico por conta da exportação do petróleo. Além disso, acrescentou que, com o tempo, os preços do petróleo diminuíram e, minorada a crise econômica, tornou-se evidente a corrupção e a ineficiência do Estado venezuelano. ${ }^{336}$

\footnotetext{
334 O Estado de S. Paulo, 20/05/1995.

335 Telegrama $n^{\circ}$ 492, 15/06/1995. De Ministério das Relações Exteriores à Embaixada do Brasil em Caracas. Ano 1995 Digitalizado.

336 GUIMARÃES, op. cit., p. 11. Cabe aqui identificar os muitos participantes das mesas de debate que se organizaram no âmbito daquele seminário, porque a listagem desses participantes pode expressar o poder de atração que o tema das relações bilaterais atingiu naquele momento. Dentre os intelectuais venezuelanos que viajaram a Brasília para participar no Seminário estavam: Giovanna de Michele; Andrés Bansart; Julio Portillo, que fora Embaixador no Brasil e publicou um livro sobre as relações bilaterais em 1982; Alejandro Mendible Zurita, professor da Universidade Central da Venezuela, e Ramón Illarramendi, Assessor da Presidência da
} 
Outras autoridades participaram do Seminário. O Governador de Roraima, Neudo Campos, referiu-se à situação peculiar de seu estado, que permanecia ligado à Venezuela sem estar conectado com o restante do território brasileiro devido à ausência de estradas asfaltadas. Esse isolamento de Roraima em relação ao restante do Brasil penalizava o estado em sua capacidade de se beneficiar do Mercosul. Por essa razão, o Governador acreditava que o Mercosul deveria buscar maior integração, não apenas com a Venezuela, mas também com os demais vizinhos do território amazônico, tal como era o caso do Peru, da Colômbia e das Guianas. Amazonino Mendes, Governador do Amazonas, concordava com esse ponto de vista. Em sua análise, ressaltou que o Mercosul possuía uma vocação capaz de integrar toda a América Latina, e não apenas os países do Cone Sul. Por isso, insistiu também na necessidade de acelerar as negociações para a associação da Venezuela àquela organização internacional. $^{337}$

Poucos dias depois do Seminário, o Conselho de Integração Empresarial se reuniu em Santa Elena de Uairén, cidade venezuelana situada na fronteira com o Brasil. A esse encontro foi atribuída alta prioridade política, como se pode notar pela presença de Ministros e Governadores dos estados brasileiros e venezuelanos. Os temas prioritários daquela reunião foram, novamente, as negociações para a entrada da Venezuela no Mercosul, as obras para asfaltamento da BR-174 e as potencialidades do comércio de fronteira entre os dois países.

A terceira reunião do grupo de trabalho sobre meio ambiente foi realizada em Brasília, entre os dias 29 e 30 de junho, e marcou a reinserção das relações bilaterais no quadro mais amplo do Tratado de Cooperação Amazônica (TCA). As delegações dos dois países concordaram em coordenar esforços para revitalizar as negociações multilaterais no âmbito do Tratado, a começar pelo seminário sobre ecoturismo que estava agendado para outubro daquele mesmo ano. Além disso, se destacaram os avanços na cooperação para pesquisa em

\footnotetext{
República. A participação de acadêmicos brasileiros foi ainda mais numerosa. Estiveram ali presentes Alcides da Costa Vaz, Amado Luiz Cervo e Luiz Alberto Moniz Bandeira, professores da Universidade de Brasília;Luiz Pinguelli Rosa, da Universidade Federal do Rio de Janeiro; Paulo Fagundes Vizentini, da Universidade Federal do Rio Grande do Sul; José Augusto Guilhon Albuquerque e Tullo Vigevani, da Universidade de São Paulo. A comunidade empresarial se fez representar por Imelda Cisneros, diretora da empresa venezuelana Axis Estratégias Empresariales; por Dorival Coelho Maranhão, da Associação Comercial e Industrial de Roraima e por José Francisco Marcondes, presidente da Câmara de Comérc io Brasil-Venezuela. Diversos funcionários do governo brasileiro estiveram representando as estatais Eletrobras e Petrobras, além da Fundação Nacional do Îndio (FUNAI), do Estado Maior do Exército e da Zona Franca de Manaus.

${ }^{337}$ Ibidem, p. 14-15.
} 
temas de biodiversidade, com o envolvimento do Instituto Nacional de Pesquisas Amazônicas (INPA), pelo lado do Brasil, e do Ministério do Meio Ambiente, pelo lado da Venezuela. ${ }^{338}$

Entre os dias 3 e 5 de julho, Fernando Henrique Cardoso visitou a Venezuela, onde presenciou a celebração do aniversário da Independência daquele país, retribuindo a visita de Rafael Caldera ocorrida no ano anterior, por ocasião dos festejos da Independênc ia do Brasil. A visita foi precedida pela publicação de um texto do embaixador venezuelano em Brasília, Alfredo Toro Hardy, no Correio Braziliense, no qual o autor saudava o novo momento das relações, enfatizando a escolha que fizera Rafael Caldera ao elevar o Brasil à categoria de "principal sócio e interlocutor no marco da política exterior da Venezuela". ${ }^{339}$ A comitiva do Presidente brasileiro era composta por membros do Congresso, dos Governadores de Roraima e do Amazonas, e dos Ministros de Estado das Relações Exteriores, das Comunicações, de Energia e Minas e do Meio Ambiente, entre outros funcionários. A visita gerou diversos documentos que se referiram à cooperação em várias áreas, envolvendo os ministérios ali representados: eles dão mostra da densidade que as relações bilaterais haviam atingido naquele momento, dos avanços logrados graças à atuação dos grupos de trabalho e, principalmente, pela prioridade conferida pela diplomacia dos dois países à integração. ${ }^{340}$

Da extensa lista de documentos gerados, cabe fazer especial menção à Declaração sobre a Formação de uma Área de Livre Comércio. Esse documento colocou ênfase, novamente, na aproximação bilateral a partir de um projeto de desenvolvimento inspirado no neoliberalismo. Tratava-se de um projeto de desenvolvimento que tinha como horizonte a liberalização dos fluxos de comércio em amplitude global e foi adaptado na América Latina para ser aplicado por etapas: da integração regional à celebração de acordos entre blocos

\footnotetext{
${ }^{338}$ Libro Amarillo referente ao ano 1995, p. 522-539.

${ }^{339}$ Correio Braziliense, 26/06/1995. É importante observar também que a elevação do status do Brasil na agenda diplo mática venezuelana coincidiu com u ma forte retração da capacidade da Venezue la em articular um projet o próprio de liderança na A mérica Latina. A crise econômica inviabilizou a continuidade dos programas de ajuda e cooperação da Venezuela co m vizinhos da América Central e do Caribe, conforme relatou o ministro conselheiro Piragibe dos Santos Tarragô, ainda em 1994, no Telegrama nº 614, 19/07/1994. De Piragibe dos Santos Tarragô, Ministro Conselheiro na Embaixada do Brasil em Caracas ao Ministério de Relações Exteriores. Ano 1994 Telegramas Recebidos Caixa 11.

${ }^{340}$ A lista de documentos assinados entre os dias 3 e 5 de julho é a seguinte: Acordo para Promoção e Proteção Recíproca de Investimentos; Ata de Miraflores; Declaração de Caracas; Protocolo Adicional ao Acordo de Complementação Econômica $\mathrm{n}^{\circ}$ 27; Acordo Complementar ao Convênio de Cooperação Técnica para o Desenvolvimento das Telecomunicações; Acordo Complementar ao Convênio Básico de Cooperação Técnica em Matéria de Planejamento; Memorando de Entendimento na Área de Mineração e Siderurgia; Acordo Complementar para a Cooperação da Região Amazônica e Orinoquense; Declaração da Venezuela e do Brasil para Formação de u ma Área de Livre Co mércio; Acordo de Transporte Internacional por Estradas de Passageiros e Cargas e Protocolo de Intenções entre a PDVSA e a Petrobrás. Todos esses documentos foram reproduzidos integralmente no Libro Amarillo referente ao ano 1995, p. 539-576.
} 
comerciais. Concretamente, o Brasil e a Venezuela negociavam a liberalização dos fluxos de comércio entre suas economias partindo do pressuposto de que essa integração constituía uma finalidade em si mesma, mas também uma etapa da aproximação entre o Mercosul e a Comunidade Andina. A integração entre esses dois blocos e eventualmente de toda a América Latina era entendida como uma forma de aumentar a capacidade de barganha da região nas negociações de liberalização comercial com outros atores, como os Estados Unidos e a União Europeia. Na Declaração, ficavam explicitadas as vantagens da integração a partir dessa perspectiva, nos seguintes termos:

La importancia de impulsar una creciente convergencia entre los procesos
subregionales de integración como etapa indispensable en el camino de la
integración suramericana, latinoamericana y hemisférica, que favorecerá el
desarrollo de la región sobre bases sostenibles, permitiendo una utilización más
eficiente de los recursos disponibles, una mayor generación de empleos y un
aumento significativo del nivelde vida de sus pueblos. ${ }^{341}$

Em meio à visita do presidente Cardoso à Venezuela, o Jornal do Brasil publicou editorial apoiando a estratégia de aproximação com aquele país. Segundo o Jornal, a viagem se revestia de uma importância política que ia além dos objetivos econômicos centrados no petróleo, nas telecomunicações e nas rodovias.

Naqueles dias, rumores de golpe circulavam pela Venezuela, que em dezessete meses de governo de Rafael Caldera não tinha conseguido se desvencilhar da crise econômica e da crise política. Nas ruas, a população permanecia mobilizada. No entanto, o referido editorial, não fazia menção a essa mobilização que expressava o descontentamento da população frente ao insucesso do modelo econômico adotado por Caldera. O jornal limitou-se a fazer referência a uma mobilização de estudantes, ou seja, de um setor específico. A intenção de minimizar as insatisfações fica implícita no titulo da publicação - "Mão peluda" - que se referia a setores ligados ao antigo governo que supostamente buscavam desestabilizar Rafael Caldera, segundo interpretava o editorialista. Cabe notar que o Jornal do Brasil participava do coro dos que apoiavam a aproximação entre os dois países e entre seus governantes.

O editorial se referia ao passado para elogiar a atuação de Fernando Henrique Cardoso como Chanceler do Brasil, atribuindo a ele a mudança no relacionamento com as autoridades venezuelanas. Referia-se também ao passado venezuelano para criticar a democracia venezuelana de fachada que, a partir de 1958 passara a ser sustentada pelo dinheiro do

${ }^{341}$ Libro Amarillo referente ao ano 1995, p. 567. 
petróleo, nos tempos de abundância, dinheiro esse que garantia a "enorme capacidade de tolerar a corrupção".

Constatamos um forte contraste entre essa interpretação do regime político venezuelano e aquela que predominava na imprensa brasileira, Jornal do Brasil incluído, nos anos 1980, quando a democracia venezuelana era constantemente festejada e comparada com a ditadura militar que vigia no Brasil. Nesse momento, a imprensa não questionava nem a "democracia" nem a "corrupção" nas referências feitas ao país vizinho. O editorial concluía sua apologia à aproximação entre os dois países, afirmando: "Hoje, a democracia é um bem precioso demais para ser colocado em segundo plano quando os presidentes se reúnem para tocar ( sic) alianças econômicas". 342

À primeira vista, pode parecer paradoxal que o editorial criticasse o modelo democrático venezuelano marcado pela corrupção e, ao mesmo tempo, desqualificasse a mobilização popular que protestava contra os corruptos. A chave para compreender essa postura contraditória reside no entendimento de que os principais jornais analisados no presente trabalho defendiam o projeto de modernização neoliberal preconizado pelo Consenso de Washington, a ser executado de cima para baixo sem a interferência dos setores populares que deveriam ser controlados pelos governantes. Em suma, os jornais denunciavam a política ineficiente e corrupta, mas condenavam os governantes que se propunham a buscar alternativas fora do Consenso para solucionar ou minimizar os problemas sociais; políticas que tinham essa finalidade eram contestadas e definidas como demagógicas, populistas ou "marxizantes". A grande imprensa, tanto venezuelana como brasileira, apoiava Fernando Henrique Cardoso e Rafael Caldera e atribuíam a eles a responsabilidade de conduzir as reformas neoliberais consideradas indispensáveis para a superação do atraso que ainda caracterizava os países da América Latina.

Por esse motivo a imprensa brasileira deu grande cobertura à visita do presidente brasileiro à Venezuela. Em telegrama datado do dia 7 de julho, o Embaixador do Brasil congratulou-se pelo sucesso daquela visita e também comentou que ela representara um ganho político para o presidente Rafael Caldera, cujo governo enfrentava crise política e econômica. Segundo o Embaixador, a visita de Cardoso reforçara a liderança de Caldera porque dera maior "visibilidade ao que muitos consideram como uma das maiores realizações

${ }^{342}$ Jornal do Brasil, 04/07/1995. 
de seu governo: a aproximação com o Brasil”. Também para o Brasil, houve ganhos com a visita, na visão do diplomata. Os dividendos eram originados, em parte, pela:

Excepcional admiração e respeito gerados junto à sociedade venezuelana pelo senhor Presidente e pela Primeira Dama, que aqui deixaram vínculos humanos duradouros e um capital de simpatia e apreço cujo valor para o desenvolvimento das relações bilaterais, não tenho dúvida, será inestimável. ${ }^{343}$

O mês de agosto marcou a entrada definitiva do governador de Roraima, Neudo Ribeiro Campos, na dinâmica das relações bilaterais como ator autônomo em relação à agenda presidencial. No dia 4, ele assinou juntamente com o Governador do estado venezuelano de Monagas, Guillermo Antonio Call, a Declaração de Monagas, através da qual assumia o compromisso de envolver, mais profundamente, a esfera estadual de governo nos esforços pela integração regional, pela cooperação e intercâmbio em matéria de tecnologia, educação, comércio, transporte, saúde, cultura e esportes. Dois dias depois, reunido com o Governador do estado venezuelano de Carabobo, Henrique Salas Römer, Neudo Campos assinou a Declaração de Roraima, assumindo os mesmos os mesmos compromissos firmados com o governador de Monagas. ${ }^{344}$

É importante notar que nenhum daqueles dois estados venezuelanos fazia fronteira com o Brasil, portanto, a celebração dos encontros de governadores se inseria na pauta de uma agenda presidencial voltada para a região de fronteira que envolvia outros envolvia outros atores, além do governo federal, no processo de integração. Este alargamento da esfera de integração indicava uma descentralização dessa política que também estava aberta à participação dos empresários. Ainda nesse contexto ocorreu a viagem de uma dele gação pernambucana à Venezuela, composta por deputados e secretários de governo, com o objetivo de convencer as autoridades venezuelanas sobre as vantagens de se construir uma refinaria de petróleo naquele estado, a partir de uma iniciativa conjunta entre a Petrobras e a PDVSA. O Ceará e o Maranhão também disputavam aquela refinaria e o Rio Grande do Norte entrou na disputa em maio de $1996 .^{345}$

\footnotetext{
343 Telegrama no 624, 07/07/1995. De Clodoaldo Hugueney Filho, Embaixador do Brasil em Caracas, ao Ministério de Relações Exteriores. Ano 1995 Digitalizado.

${ }^{344}$ Libro Amarillo referente ao ano 1995, p. 577-578.

345 Telegrama no 792, 30/08/1995. De Clodoaldo Hugueney Filho, Embaixador do Brasil em Caracas, ao Minis tério de Relações Exteriores. Ano 1995 Dig italizado. Correio Braziliense, 22/05/1996.
} 


\subsubsection{Persistência da crise econômica na Venezuela}

Enquanto as relações bilaterais evoluíam, o cenário político e econômico na Venezuela permanecia instável. Durante todo o ano de 1994 e primeiro semestre de 1995, a Venezuela acumulou atrasos nos pagamentos da dívida externa, e em agosto aventava a possibilidade de declarar moratória por insuficiência de reservas. Os governos dos países credores, contudo, organizados no Clube de Paris, pressionavam a Venezuela, advertindo que a moratória, que não estava de acordo com o FMI, não seria bem vista e acarretaria "graves problemas de crédito" para o país. ${ }^{346}$ Esta situação contrastava sensivelmente com o cenário brasileiro no qual a estabilização econômica proporcionada pelo Plano Real garantiu ao governo índices satisfatórios de popularidade.

A Comissão Mista Venezuelano-Brasileira sobre Entorpecentes e Substâncias Psicotrópicas se reuniu em Caracas entre os dias 19 e 20 de setembro, cumprindo decisão que fora tomada na reunião da COBAN, em julho. As delegações trocaram conhecimento a respeito da legislação sobre a matéria vigente nos dois países, e concordaram em que a abordagem do problema deveria ser feita de maneira mais ampla, envolvendo também a cooperação na difusão de informações concernentes ao sigilo bancário e no combate à lavagem de dinheiro. Além disso, as delegações também concordaram em relação à necessidade de serem realizadas atividades conjuntas de repressão e policiamento das fronteiras. Essa reunião marcou a evolução da cooperação policial fronteiriça que ultrapassava as questões que envolviam o problema do garimpo clandestino, passando então a se responsabilizar pelos problemas relacionados ao tráfico de drogas. ${ }^{347}$

Ainda naquele mês, as autoridades venezuelanas realizaram um seminário sobre as relações bilaterais, em Caracas. A iniciativa consistiu em uma contrapartida ao seminário que se realizou em Brasília, durante o mês de junho. O seminário venezuelano foi organizado pela Comissão Presidencial para a Reforma do Estado (Copre) e pelo Centro de Estudos sobre o Desenvolvimento (CENDES), ligado à Universidade Central da Venezuela. Os organizadores do Seminário se empenharam em garantir igual suces so em relação ao do seminário brasileiro e, para tanto, envolveram funcionários do Estado, acadêmicos e empresários no evento que

\footnotetext{
346 O Estado de S. Paulo, 30/08/1995.

${ }^{347}$ Libro Amarillo referente ao ano 1995, p. 578-586.
} 
discutiu os projetos bilaterais. Em relatório sobre esse evento, o Embaixador brasileiro ressaltou o prestígio conferido pelo discurso de abertura pronunciado pelo chanceler Burelli Rivas e pela presença de veículos de comunicação (jornais e televisão). Para o Embaixador, tanto a iniciativa de organizar o seminário quanto o sucesso com que ele foi conduzido demonstravam que, na Venezuela, o interesse pelas relações com o Brasil se ampliara muito além do âmbito governamental. ${ }^{348}$

Entre os dias 5 e 6 de outubro, uma delegação brasileira chefiada por um funcionário do Ministério da Agricultura visitou Caracas, onde se reuniu com o Ministro venezuelano de Agricultura, Raúl Alegrett, para criar o décimo grupo bilateral de trabalho, cujas negociações versariam sobre aquele tema. Este foi o último grupo de trabalho a ser instalado, dentre todos os que resultaram do novo fôlego de cooperação iniciado na reunião de Guzmania. Era objetivo do grupo propiciar a cooperação técnica para programas de produção e controle de insumos pecuários e diagnósticos de laboratórios; para harmonização de normas, procedimentos e requisitos legais das atividades agropecuárias; para realização de campanhas sanitárias e preventivas na região e fronteira e para estabelecer acordos para importação e exportação de materiais de multiplicação animal e produtos químicos e bioló gicos. ${ }^{349}$

No entanto, a instabilidade na Venezuela aumentara naqueles meses finais de 1995. Em outubro, o FMI passou a exigir flexibilização da taxa de câmbio, que estava sendo mantida em 170 bolívares por dólar. A perspectiva de que a Venezuela não teria co ndições de honrar o pagamento de US\$ 2 bilhões em serviço da dívida agravava a pressão contra a economia venezuelana. Nas ruas, os protestos se intensificavam e uma manifestação de estudantes e professores universitários redundou em confrontos que envolveram cerca de 10 mil manifestantes e dois mil soldados da Guarda Nacional. O confronto foi o pior desde que Caldera assumira o governo, e fez com que os noticiários recordassem os eventos de 1989 e 1992. Na falta de perspectivas para a elevação dos preços internacionais do petróleo, único motor da economia venezuelana, o governo admitiu, em novembro, a disposição em recorrer ao FMI para receber ajuda financeira. No mês seguinte, as eleições que elegeram prefeitos,

\footnotetext{
348 Telegrama $n^{\circ}$ 882, 29/09/1995. De Clodoaldo Hugueney Filho, Embaixador do Brasil em Caracas, ao Ministério de Relações Exteriores. Ano 1995 Dig italizado.

${ }^{349}$ Libro Amarillo referente ao ano 1995, p. 586-592. No documento, não foi identificado o nome nem o cargo do funcionário do Ministério da Agricu ltura do Brasil.
} 
governadores e deputados foram marcadas pela abstenção recorde de $65 \%$ dos eleitores, refletindo a descrença dos venezuelanos em relação ao sistema político de seu país. ${ }^{350}$

Nesse contexto, mais uma vez a aproximação com o Brasil, que Rafael Caldera estimulara, foi de grande ajuda para o governo. Para responder à crise econômica, o governo preparava um plano de estabilização, a ser apresentado no ano seguinte, para o qual solicitou, seguidas vezes, ao longo do ano, a assistência do governo brasileiro. Caldera se reunira com Fernando Henrique Cardoso em Nova York e, nessa ocasião, solicitou que o mandatário brasileiro enviasse à Venezuela membros da equipe econômica para relatarem a experiência brasileira de combate à crise; o Presidente brasileiro acedeu a essa demanda, prometendo que enviaria para o país vizinho, o Ministro da Fazenda, Pedro Malan e o Presidente do Banco Central, Gustavo Loyola. Os venezuelanos consideravam a assistência brasileira especialmente importante porque estavam em negociações com o FMI para a implementação de um ajuste "duro" na economia do país. ${ }^{351}$

Nos dias 15 e 16 de janeiro, o Presidente do Banco Central do Brasil, Gustavo Loyola, reuniu-se com o Presidente do Banco Central da Venezuela, Antonio Casas González, e com o Ministro da Fazenda, Luis Raúl Matos Azócar. Em decorrência dessa reunião, as autoridades venezuelanas enviaram uma missão técnica ao Brasil, entre os dias 4 e 6 de março, para avançar nas negociações em matéria de cooperação financeira e assistência para um novo programa econômico, inspirado no Plano Real. A missão venezuelana recebeu tratamento especial no Brasil: foi recebida pelo Ministro da Fazenda do Brasil, Pedro Malan, e pelo Presidente da Comissão de Política Exterior da Câmara dos Deputados, Franco Montoro. Quase do is anos após o "estouro" da crise bancária de 1994, o governo venezuelano havia nacionalizado sete grandes bancos no país, e naquele momento buscava a cooperação brasileira para novamente privatizá-los. ${ }^{352}$

Entre os dias $1^{\circ}$ e 2 de fevereiro, celebrou-se, em Brasília, a quinta reunião do Mecanismo de Consulta, cuja finalidade era preparar a próxima reunião da COBAN. As negociações para formação de uma área de livre comércio entre a Venezuela e o Mercosul

\footnotetext{
${ }^{350}$ O Globo, 04/12/1995. Ver também O Estado de S. Paulo, 04/10/1995 e 13/10/1995, além de Jornal do Brasil, 05/11/1995.

${ }^{351}$ Telegrama $n^{\circ}$ 1100, 29/11/1995. De Piragibe dos Santos Tarragô, Ministro Conselheiro na Embaixada do Brasil em Caracas, ao Ministério de Relações Exteriores. Ano 1995 Digitalizado.

352 Relatório publicado no Libro Amarillo referente ao ano 1996, p. 151, diz que a visita de Gustavo Loyola aconteceu em fevereiro, o que constitui um erro, uma vez que $O$ Globo publicou reportagem no dia 15 de janeiro noticiando a visita.
} 
foram destacadas na reunião do Mecanismo. Também foram analisados os resultados dos encontros mantidos por cada um dos grupos de trabalho. Os dois Vice-Ministros, que chefiaram as delegações presentes ao encontro, ressaltaram a coincidência de pontos de vista entre a diplomacia dos dois países no que dizia respeito à agenda de liberalização das relações econômicas internacionais. ${ }^{353}$

\subsection{A SEGUNDA FASE DO NEOLIBERALISMO: NOVAS DIRETRIZES ECONÔMICAS}

Em março de 1996, Rafael Caldera reconheceu o fracasso de sua política econômica, caracterizada pela combinação de medidas do projeto neoliberal como as privatizações, juntamente com a permanência de elementos heterodoxos, como a fixação de preços e subsídios à atividade econômica. O Presidente anunciou ampla reforma ministerial, nomeando o dirigente socialista Teodoro Petkoff para o cargo de Ministro do Planejamento com o intuito - paradoxal tendo em vista a história política de Petkoff - de imprimir novo fôlego às reformas neoliberais. O Estado de S. Paulo reconheceu o aparente paradoxo na indicação do socialista (cujo partido, MAS, já havia aderido à coligação que elegeu Rafael Caldera), assinalando:

\footnotetext{
Em contraste com suas opções ideológicas passadas e presentes, o ministro apresentou um programa de reformas liberais que inclui a redução do número dos funcionários e dos gastos públicos, o fim do subsídio à gasolina - considerada a mais barata do mundo - e a liberação do câmbio. (...) O governo pretende com essas medidas se qualificar para um acordo com o FMI, protelado diversas vezes, que agora volta a ser negociado. ${ }^{354}$
}

Rapidamente, o novo Ministro passou a ser a figura pública mais identificada com o novo plano econômico, chamado Agenda Venezuela. Esse plano incluía a retirada de subsídios ao preço da gasolina como forma de reduzir os gastos do Estado. Esta medida era particularmente delicada tendo em vista a memória do Caracazo, que se iniciara em razão de medida semelhante.

\footnotetext{
${ }^{353}$ Libro Amarillo referente ao ano 1996, p. 609-618.

${ }^{354}$ O Estado de S. Paulo, 19/03/1996.
} 


\subsubsection{A Venezuela frente ao FMI}

Em decorrência da falta de subsídio, o preço da gasolina se multiplicou por 10. Houve corrida aos bancos e supermercados motivada pela apreensão frente ao novo plano. As taxas de juros e de câmbio foram liberadas do controle exercido, anteriormente, pelo governo e passaram a ser determinadas por critérios de mercado. O Ministro sugeriu ainda a demissão de 500 mil funcionários públicos, a serem realizadas ao longo dos três anos seguintes. Ao Jornal do Brasil, o ministro Petkoff declarou: "Já se foi o tempo em que poderíamos tomar medidas graduais. Vamos ter uma liberação total do mercado cambial, seja na conta corrente, seja na conta de capital". 355

Enquanto a população seguia se manifestando nas ruas, o Secretário-Geral da Confederação dos Trabalhadores da Venezuela (CTV), principal representação sindical, declarou uma tímida oposição ao novo plano econômico. Segundo ele, o custo social era muito elevado, mas a situação caótica da economia do país não permitiria que a CTV confrontasse o governo. Dessa forma, a Confederação, que era ligada ao partido da Ação Democrática, se descolava dos anseios das ruas, o que contribuiu para o desgaste final do sistema político venezuelano. Também o Copei apoiou a Agenda Venezuela, assim como a entidade empresarial Fedecámaras. Os apoios mais importantes, porém, do ponto de vista da estratégia do governo, vieram do Banco Mundial, do Banco Interamericano de Desenvolvimento e do FMI, que anunciaram um pacote de ajuda à Venezuela como reconhecimento pela adesão do governo ao Consenso de Washington. A mudança de atitude do presidente Caldera frente ao neoliberalismo e ao FMI não escapou à Gazeta Mercantil, que publicou reportagem na qual apontava a necessidade do Presidente recuar de sua "plataforma populista", com a qual prometera, em campanha eleitoral, não aumentar o preço da gasolina nem recorrer ao FMI. ${ }^{356}$

A implementação da Agenda Venezuela e a assinatura de um acordo com o FMI, que foram anunciados pelo Presidente em cadeia nacional de rádio e televisão no dia 15 de abril de 1996, marcaram um segundo momento chave da trajetória venezuelana de busca pela saída da crise econômica que se abateu sobre aquele país desde a elevação dos juros da dívida e

\footnotetext{
355 Jornal do Brasil, 11/04/1996. Gazeta Mercantil, 13/05/1996.

${ }^{356}$ Gazeta Mercantil, 17/04/1996. Jornal do Brasil, 21/04/1996. Gazeta Mercantil, 23/04/1996.
} 
redução dos preços internacionais do petróleo. ${ }^{357}$ Lembramos que o primeiro momento ocorreu quando Carlos Andrés Pérez aderiu às reformas neoliberais e aos acordos como FMI, em contradição com a sua trajetória de político nacionalista e com as expectativas que criou durante sua campanha eleitoral de 1988. As reformas acabaram sendo desaceleradas em razão da forte resistência da sociedade venezuelana entre os anos de 1989 e 1992, que acabaram inviabilizando politicamente o governo de Carlos Andrés Pérez. Nesse segundo momento, Rafael Caldera repetiu a trajetória de seu antecessor, abandonando antigas promessas de campanha e aderindo ao receituário do Consenso de Washington. A forma como essa adesão se processou na Venezuela marca flagrante contraste com o processo brasileiro, onde o candidato Luiz Inácio Lula da Silva, crítico do neoliberalismo, foi derrotado nas eleições de 1989 e 1994 por candidatos identificados com a modernização neoliberal.

O caso brasileiro e o caso venezuelano guardam semelhanças quanto aos seus resultados: por um caminho ou por outro, chegou-se à adesão (voluntária ou forçada) às condições que os representantes das agências financeiras internacionais impuseram para a retomada dos fluxos financeiros, empréstimos e investimentos. Esses movimentos, que também ocorreram na maioria dos países latino-americanos no período, desautorizam a interpretação de que a adesão ao neoliberalismo foi uma decisão de submissão voluntária ou servilismo de determinados grupos políticos nesses países em oposição ao que seria entendido como "verdadeiro interesse nacional". ${ }^{358} \mathrm{O}$ fato de que, tanto políticos comprometidos ideologicamente com o Consenso de Washington, como os refratários a ele, tenham finalizado por reformar as economias de seus países demonstra que o determinante para essa decisão não era decorrente do comprometimento pessoal dos governantes com aquela agenda externa, mas sim das relações de poder marcadamente assimétricas entre países com escassez de capital e de capacidade de geração interna de capital, de um lado, e países detentores dos recursos necessários para o funcionamento das economias capitalistas, de outro.

\footnotetext{
357 Telegrama $\mathrm{n}^{\text {o }}$ 341, 17/04/1996. De Clodoaldo Hugueney Filho, Embaixador do Brasil em Caracas, ao Ministério de Relações Exteriores. Ano 1996 Dig italizado.

${ }^{358}$ Exemp los desse tipo de interpretação podem ser encontrado em CERVO, A mado. L. "A ação internacional do Brasil em um mundo em transformação: conceitos, objetivos e resultados (1990-2005)". In: ALTEMANI, Henrique; LESSA, Antonio C. Relações Internacionais do Brasil: temas e agendas. São Paulo: Saraiva, 2006, e também CERVO, A mado L. Relações Internacionais da América Latina - velhos e novos paradigmas. Brasília: IBRI, 2001.
} 
As elites governantes dos países latino-americanos, incluindo os grupos de apoio a Carlos Andrés Pérez, Rafael Caldera, Fernando Collor ou Fernando Henrique Cardoso, não podiam contestar a legitimidade da posição que os credores mantinham nesse processo sem questionar a própria relação de propriedade entre os bancos internacionais e os recursos que eles haviam emprestado aos países latino-americanos, ou seja, sem contestar o sistema capitalista. O rechaço ao capitalismo, condição necessária para a recusa consequente dos termos de negociação impostos pelos credores e pelo FMI, era uma posição que não estava ao alcance daqueles políticos, por mais críticos que pudessem parecer em relação às instituições da economia internacional, uma vez que suas trajetórias pessoais e suas bases de apoio eram construídas a partir de ligações com interesses do empresariado em seus próprios países, incluindo os proprietários dos meios de comunicação que defendiam, ardorosamente, a modernização neoliberal através das mídias sob seus comandos.

A adesão da Venezuela às negociações com o FMI selou o enquadramento da cooperação bilateral dentro dos preceitos do Consenso de Washington, o que significou o abandono de qualquer intenção de transformá-la em eixo de contestação ao sistema econômico internacional, tal como se aventou tantas vezes na década de 1980; lembramos que, nesse período, a formação de unidade de devedores na América Latina era uma ideia em voga.

\subsubsection{A visita de Caldera ao Brasil: novo marco nas aproximações}

As mudanças ocorridas na Venezuela permitiram maior aproximação com o governo brasileiro. No final de abril de 1996, essa aproximação era visível: uma delegação de parlamentares venezuelanos visitou o Brasil. Chefiada pelo Presidente da Câmara dos Deputados, Ramón Guillermo Aveledo, a missão tinha como objetivo estreitar o relacionamento com os parlamentares do Brasil, constituindo mais um laço institucional que se somou às reuniões presidenciais, ministeriais, de governadores e de empresários. ${ }^{359}$

\footnotetext{
${ }^{359}$ Libro Amarillo referente ao ano 1996, p. 152.
} 
No começo de maio, reuniu-se o grupo de trabalho responsável pelo desenvolvimento fronteiriço. Dessa reunião resultou o enquadramento das relações de fronteira em um âmbito predominantemente comercial, a partir da instituição de três Comitês de Cooperação destinados a facilitar os procedimentos aduaneiros, a realizar cooperação em matéria de comércio e a aperfeiçoar as redes de transporte na região. Logo mais, o grupo de trabalho relacionado à ciência e tecnologia se reuniu em Brasília. ${ }^{360}$

Mas o principal evento ocorrido no âmbito das relações bilaterais naquele mês de maio foi a visita do presidente Rafael Caldera ao Brasil. Entre os dias 19 e 23, o presidente venezuelano chefiou extensa delegação, composta de ministros, parlamentares, técnicos e empresários. Durante jantar oferecido a ele, proferiu discurso no qual resumiu as motivações de sua visita e as afinidades que julgava haver entre os dois países e entre os dois presidentes. Em primeiro lugar, identificou a Venezuela como uma potência energética, com interesse em comercializar essa energia com o Brasil. A seguir, afirmou que as negociações de integração entre os dois países transcendiam o espectro das relações bilaterais e se inseriam em um contexto mais amplo de integração latino-americana. O Mercosul foi identificado por ele como um acordo similar ao do Pacto Andino e, neste sentido, considerou que a aproximação política e comercial entre o Brasil e a Venezuela representaria um movimento importante para a interação entre os dois blocos regionais, até porque, os dois países compartilhavam como fronteira a floresta amazônica.

No que diz respeito às trajetórias pessoais dos dois presidentes, Rafael Caldera procurou destacar afinidades entre ele e Fernando Henrique Cardoso, lembrando que ambos fizeram carreira acadêmica na área de sociologia. Com isso queria salientar que os dois políticos tinham, em decorrência de suas respectivas formações, "preocupação com o social". Mas essa preocupação não os eximia de tomarem "medidas indispensables, muchas de ellas duras, porque tenemos que reconocer el movimiento mundial de globalización de la economía". 361

Ainda durante sua visita, o presidente venezuelano concedeu uma entrevista coletiva, na qual Maria Elena Tachinardi, da Gazeta Mercantil, indagou sobre a possibilidade de o Brasil oferecer à Venezuela conhecimento para a realização de suas reformas econômicas; o

\footnotetext{
${ }^{360}$ Libro Amarillo referente ao ano 1996, p. 153 e 489.

${ }^{361}$ Libro Amarillo referente ao ano 1996, p. 511.
} 
presidente respondeu que, ressalvadas as diferenças existentes entre os países, desejava conhecer melhor os antecedentes e o desenvolvimento do Plano Real, inquestionavelmente bem sucedido. Respondendo a outra pergunta, sobre a importância do Mercosul na agenda dos dois países, Caldera afirmou ser possível concluir acordos entre a Venezuela e o Mercosul ainda naquele ano. ${ }^{362}$

A agenda de Caldera em território brasileiro incluiu visitas à sede da Confederação Nacional das Indústrias (CNI), ao Congresso Nacional e à Universidade de Brasília, todas realizadas no mesmo dia. $\mathrm{Na}$ sede da CNI, o presidente venezuelano destacou a importância do envolvimento da sociedade civil (no caso, os empresários) na integração regional, a exemplo do que acontecia na Europa. Sobre o processo de privatização das empresas estatais, esclareceu que não eram resultado de concepções ideoló gicas, como diziam seus críticos, mas sim da necessidade. Aproveitou ainda para convidar os empresários brasileiros a que participassem dos leilões de privatização:

Em materia de minería, el Brasil nos puede aportar, no solamente capital y técnica, sino una gran experiencia. No queremos caer en los errores en que muchas veces se incurrió en los países mineros, que solamente sirvieron como teatro de paso para que algunos inversionistas llegaran, explotaran nuestras riquezas y se las llevaran. El Brasil nos puede dar mucho em este sentido y la participación de los brasileños puede ser para nosotros realmente considerable. ${ }^{363}$

Freddy Rojas Parra, Ministro de Fomento da Venezuela, também discursou naquela ocasião, reforçando a estratégia venezuelana de harmonizar o processo de liberalização comercial através da aproximação com o Brasil. Reforçou ainda o convite de Rafael Caldera para que os empresários brasileiros contribuíssem no processo de privatizações:

Creo señores, y allí quizás va un poco de mi experiencia empresarial, que la oportunidad de invertir se vuelve exitosa en su proyección, no sólo en el momento de la cresta del ciclo económico; la oportunidad suele darse y allí se explica el éxito de muchos empresarios cuando el ciclo económico empieza y da muestras de un proceso de recuperación. ${ }^{364}$

O presidente da Fedecámaras, Jorge Serrano, destacou o crescimento do comércio fronteiriço, que criava mais oportunidades para as exportações não tradicionais venezuelanas. Por essa razão, a Fedecámaras decidira patrocinar um evento de promoção comercial na capital de Roraima intitulado: "Venezuela expone en Boa Vista". Ficou claro ainda que Serrano compartilhava a estratégia de liberalização comercial traçada por Rafael Caldera

\footnotetext{
${ }^{362}$ EMBAIXADA DA VENEZUELA NO BRASIL, op. cit., p. 86-89.

363 Ibid., p. 126.

364 Ibid., p. 133.
} 
quando se referiu às negociações para assinatura de um acordo entre a Venezuela e o Mercosul para constituir uma zona de livre comércio. Naquele mesmo dia 21 de maio, Caldera foi recebido ainda no Congresso Nacional brasileiro. Roberto Requião, senador pelo estado do Paraná, fez um discurso de boas vindas em que destacou a centralidade do Mercosul na construção de um bloco econômico formado por todas as economias latino-americanas. ${ }^{365}$ $\mathrm{Na}$ Universidade de Brasília, Rafael Caldera ministrou Aula Magna sobre o "Valor da democracia como sistema na América Latina: a experiência venezuelana". 366

Resultaram dessa visita a Declaração de Brasília e a Ata do Planalto. Esse último documento explicitou o apoio do governo brasileiro ao Plano de Estabilização Econômica conduzido pelo governo venezuelano, e também conhecido como Agenda Venezuela; ele se fundamentava na estratégia neoliberal de retirada dos subsídios estatais à economia, de fomento às privatizações e de liberalização cambial. A Ata do Planalto também registrou o chamado de Rafael Caldera a que os empresários brasileiros participassem nos leilões de privatização venezuelanos. Para tanto, os presidentes concordaram em apoiar a realização de missões de negócios que servissem para ampliar o conhecimento mútuo das elites empresariais.

Cabe frisar, ainda em relação a esse documento presidencial que, pela primeira vez, um documento dessa natureza conferia especial importância aos aspectos culturais e educativos da integração, saudando a realização próxima do evento "Presença Cultural da Venezuela no Brasil", que previa a exibição de produção artística daquele país nas cidades de Brasília, Manaus, São Paulo e Rio de Janeiro. Além desse evento, ficou agendada também a celebração da "Semana da Amazônia" em Caracas, com o apoio das instituições culturais dos governos de Amazonas e de Roraima. Também em Caracas, havia sido realizado, naquele ano, a terceira "Semana do Brasil". Finalmente, mencionamos o compromisso, reconhecido no documento oficial, de criação de uma orquestra juvenil na cidade brasileira de Campos com a assistência da Fundação do Estado para Formação de Orquestras Juvenis da Venezuela. 367

A Declaração de Brasília cristalizou a estratégia dos dois governos para aprofundar a integração em nove pontos de ação, que podem ser assim resumidos: compromisso dos

\footnotetext{
${ }^{365}$ Ibid., p. 145-148.

366 Ibid., p. 187.

${ }^{367}$ Libro Amarillo referente ao ano 1996, p. 997-1003.
} 
presidentes de manter o seu envolvimento nas negociações e programas de cooperação; compromisso dos governos com a forma de governo democrática e com a justiça social; cooperação econômica em um contexto de reformas para garantir a estabilidade e o crescimento sustentado; integração energética e mineradora; integração física e ambiental na região de fronteira; ênfase na construção de confiança e na realização concreta de iniciativas conjuntas; construção de um espaço integrado na América do Sul e, posteriormente, na América Latina; incentivo à integração cultural e à difusão do conhecimento mútuo; e continuação do "diálogo fluido y constante que hemos establecido, caracterizado por la más irrestricta confianza, comprometiéndonos a continuar utilizando plenamente los mecanismos institucionales de cooperación bilateral existentes". 368

Tal era a percepção sobre a importância, considerada inédita, da proximidade política atingida pelos dois países à época quando Márcio Moreira Alves escreveu um balanço da visita, na edição de 23 de maio d' $O$ Globo:

A visita do Presidente da Venezuela teve, como é natural, suas doses de protocolo. Mas foi, possivelmente, a mais objetiva e promissora de todas que aconteceram no Brasil, desde o encontro entre José Sarney e Raúl Alfonsín, que assentou as bases do Mercosul. ${ }^{369}$

Em junho, Rafael Caldera discursou ao Parlamento Andino, afirmando que a aproximação entre o Brasil e a Venezuela era o elemento-chave para a integração latinoamericana, através da aproximação entre o Pacto Andino e o Mercosul. Em seu discurso, Caldera contextualizou essas relações expondo um movimento mais amplo de integração hemisférica, que envolvia também o México e a Colômbia (com quem a Venezuela estava associada no Grupo dos Três), os países do Caribe e os Estados Unidos.

No mês seguinte, a proximidade com o Brasil serviu de inspiração para uma reforma do sistema cambial venezuelano. Em telegrama que noticiava a reforma, o Embaixador brasileiro enfatizou ter sido resultado das viagens de economistas ligados ao governo do Brasil, Pérsio Arida e Edmar Bacha. ${ }^{370}$

Entre os dias 29 de setembro e 2 de outubro, uma delegação de empresários paulistas visitou a Venezuela com a finalidade de estreitar os contatos com o setor empresarial daquele

\footnotetext{
${ }^{368}$ Libro Amarillo referente ao ano 1996, p. 1003-1005.

${ }^{369}$ EMBAIXADA DA VENEZUELA NO BRASIL, op. cit., p. 16.

370 Telegramas no 514, 13/06/1996 e n⿳0 592, 10/07/1996. De Clodoaldo Hugueney Filho, Embaixador do Brasil em Caracas, ao Ministério de Relações Exteriores. Ano 1996 Digitalizados.
} 
país, buscando gerar negócios nos setores petrolífero, hidrelétrico, minerador e siderúrgico a partir da proximidade política promovida pelas autoridades. A visita foi coordenada pela embaixada brasileira em Caracas e o consulado geral da Venezuela em São Paulo. Os empresários brasileiros pretendiam incrementar seus negócios com o país vizinho aproveitando o contexto de retomada das privatizações. Mas esse processo ainda caminhava lentamente.

No dia 4 de outubro, logo após a viagem dos empresários para a Venezuela, a revista The Economist e a Gazeta Mercantil publicaram matéria que apontava o fracasso do governo venezuelano na tentativa de imprimir maior ritmo às privatizações, em razão do aumento dos preços do petróleo causado pelos conflitos no Oriente Médio e da utilização das empresas estatais para patrocínio dos principais partidos políticos. ${ }^{371}$

A quinta reunião da COBAN teve lugar em Caracas, em outubro. O chanceler brasileiro Luiz Felipe Lampreia foi recebido pelo Presidente da Venezuela e também se encontrou com diversos ministros, além dos presidentes do Senado e da Câmara de Deputados. Além disso, foi convidado a proferir uma conferência na Universidade Central da Venezuela.

Como se pode notar, o representante brasileiro recebeu tratamento pouco usual para um Ministro de Estado, sinal indicativo da prioridade que as autoridades venezuelanas conferiam à aproximação com o Brasil. Nessa reunião do COBAN, as delegações dos dois países concluíram que os grupos de trabalho sobre comércio e integração e sobre transporte haviam concluído, satisfatoriamente, os seus mandatos e por esse motivo foram extintos. No entanto, dois outros grupos começaram a atuar: o que deveria promover o turismo e o que tinha como objetivo promover a cooperação entre pequenas e médias indústrias. Além disso, as negociações para a associação da Venezuela ao Mercosul foram novamente objeto prioritário da reunião. ${ }^{372}$

Em novembro, o Embaixador brasileiro compareceu a um almoço promovido pela Câmara de Comércio Venezuelano-Brasileira em homenagem ao Ministro do Planejamento da Venezuela, Teodoro Petkoff. Tal almoço aconteceu na véspera de uma viagem do Ministro venezuelano ao Brasil, onde manteria encontros oficiais em Brasília e com empresários em

\footnotetext{
371 Libro Amarillo referente ao ano 1996, p. 153. Gazeta Mercantil, 04/10/1996.

${ }^{372}$ Libro Amarillo referente ao ano 1996, p. 153.
} 
São Paulo. Petkoff apresentou aos presentes um balanço autocongratulador a respeito dos resultados da Agenda Venezuela, embora admitisse que muitas expectativas não tivessem sido cumpridas.

Atento aos interesses de sua audiência, o Ministro reiterou a firme decisão do governo venezuelano em prosseguir e aprofundar as privatizações e os cortes no funcionalismo público. Em harmonia com as reformas internas da economia, o governo manteria sua estratégia de abertura econômica, dentro da qual a aproximação com o Brasil representava prioridade máxima. ${ }^{373}$ Já no último dia do ano de 1996, o embaixador Clodoaldo Hugueney enviou, ao Ministério, um telegrama no qual fazia um balanço bastante favorável da evolução das relações bilaterais. Segundo o Embaixador, aquele ano fora "altamente propício à promoção da imagem do Brasil”, principalmente porque a aproximação bilateral conta va com "grande receptividade junto aos meios de comunicação, às mais importantes instituições acadêmicas e culturais e acadêmicas e junto ao público em geral". 374

\subsubsection{FHC e Rafael Caldera: protagonistas do encontro de 11de abril de 1996}

A integração energética continuava a ser um dos principais eixos estratégicos das relações entre o Brasil e a Venezuela. Em janeiro, foi finalmente assinado um contrato entre as estatais Edelca e Eletrobrás para que a Venezuela vendesse a energia excedente da usina hidrelétrica de Guri ao estado brasileiro de Roraima. Em reportagem sobre o assunto, a Gazeta Mercantil enfatizou que aquele acordo significava um avanço nos esforços dos dois governos para estabelecer na região uma dinâmica integradora semelhante ao que o Brasil desenvolvia junto aos países do Cone Sul. ${ }^{375}$ No mês seguinte, o Jornal do Brasil noticiou a meta venezuelana de suprir $25 \%$ do consumo brasileiro de petróleo, desbancando os principais fornecedores que eram a Arábia Saudita e a Argentina. Para conseguir esse objetivo, os venezuelanos se apoiavam nos bons resultados nos quatro anos anteriores,

\footnotetext{
373 Telegrama no 974, 26/11/1996. De Clodoaldo Hugueney Filho, Embaixador do Brasil em Caracas, ao Ministério de Relações Exteriores. Ano 1996 Digitalizado.

374 Telegrama ${ }^{\circ}$ 1068, 31/12/1996. De Clodoaldo Hugueney Filho, Embaixador do Brasil em Caracas, ao Ministério de Relações Exteriores. Ano 1996 Dig italizado.

${ }^{375}$ Gazeta Mercantil, 30/01/1997.
} 
período de tempo em que a Venezuela mais do que dobrou a quantidade de petróleo vendida ao Brasil.

No dia 11 de abril, Rafael Caldera viajou ao Brasil, visitando as cidades de Manaus e Boa Vista, onde assinou com Fernando Henrique Cardoso um contrato para o fornecimento de energia elétrica venezuelana àquela cidade. Os dois presidentes foram recebidos pelo governador Neudo Campos, que fez discurso celebrando o progresso das obras para asfaltamento da BR-174 e para a transmissão de energia da usina hidrelétrica de Guri para o território roraimense. ${ }^{376} \mathrm{O}$ presidente brasileiro parabenizou seu homólogo venezuelano pela importância que teve no processo de "reconstrução" das relações bilaterais, a partir de seu encontro com o ex-presidente brasileiro, Itamar Franco, ainda em março de 1994. Fernando Henrique ainda afirmou que:

Essa aproximação entre a Venezuela e o Brasil se iniciou durante os mandatos do presidente Caldera e do presidente Itamar Franco, quando este último realizou uma visita a Caracas, oportunidade na qual pude testemunhar, como Ministro das Relações Exteriores do Brasil, o significado dessa aproximação entre Brasil e Venezuela. ${ }^{377}$

O triunfalismo dessa declaração é característico dos encontros entre autoridades internacionais. Em diversas ocasiões os mandatários se congratularam pelo que entendiam ser o ineditismo de suas iniciativas diplomáticas. No entanto, o ineditismo dos encontros ocorridos entre Itamar Franco e Rafael Caldera, apontado também por Mônica Loss ${ }^{378}$ e Alfredo Toro Hardy, Embaixador da Venezuela no Brasil, é apenas relativo. ${ }^{379}$

As pesquisas que realizamos sobre esta questão mostram que tal perspectiva não se sustenta. Se tomarmos por base a frequência de encontros presidenciais como evidência de proximidade política, devemos nos remeter aos encontros entre José Sarney e Jaime Lusinchi que podem ser considerados os pontos de partida dessa aproximação: a partir deles, todos os presidentes dos dois países se encontraram todos os anos, exceto em 1992 e 1993, quando estiveram no poder Carlos Andrés Pérez e Itamar Franco. Se considerarmos que a formação de grupos de trabalho permanentes promovidos pelas chancelarias são indicadores confiáveis

\footnotetext{
${ }^{376}$ Libro Amarillo referente ao ano 1997, p. 139. EMBAIXADA DA VENEZUELA NO BRA SIL, op. Cit., p. 261-266.

${ }^{377}$ P. 268.

${ }^{378}$ LOSS, op. cit., p. 82

379 Alfredo Toro Hardy, que era o Embaixador da Venezuela naquele momento, posteriormente escreveu: "La llegada por segunda vez a la presidencia de la República del doctor Rafael Caldera, en 1994, transformó completamente el ámbito de las relaciones bilaterales”. EMBAIXADA DA VENEZUELA NO BRASIL, op. Cit., p. 11.
} 
de cooperação, podemos estabelecer como marco inicial o encontro de chanceleres em junho de 1991, quando foram criados o Mecanismo de Consulta Política e o Grupo de Trabalho de Cooperação Técnica. Mais apropriado, porém, seria compreender a aproximação política entre o Brasil e a Venezuela como um processo construído gradualmente, sem interrupções, desde 1983, momento em que a crise econômica forçou uma revisão dos modelos de inserção dos países na política e na economia internacional. No ano seguinte a formação do Grupo de Contadora também contribuiu para esse processo.

Em seu discurso, Fernando Henrique Cardoso expressou a continuidade do projeto estratégico de constituir o Mercosul como centro da integração, dessa vez não mais latinoamericana, mas sul-americana:

Percebemos que é necessário conseguir mais. E esse mais é a integração crescente
entre Brasil e Venezuela, da Venezuela com o Mercosul, para formar realmente um
grande mercado, não apenas consumidor mas produtor e para que possamos nos
lançar a aventuras ainda maiores de integração hemisférica e de cooperação com a
União Europeia, de cooperação com os países da Ásia, em condições mais
favoráveis a nossos povos. ${ }^{380}$

No referido 11 de abril de 1996, os dois presidentes viajaram, com suas respectivas comitivas, para Manaus, onde se encerrava o encontro empresarial Brasil-Venezuela. Em seu discurso, Rafael Caldera mostrou adesão ao planejamento estratégico do presidente brasileiro, afirmando:

En este momento, pues, estamos impulsando el proceso de integración. He dicho que en una mentalidad como la de Fernando Henrique Cardoso, la idea de Mercosur no es la de un coto cerrado, la de un mercado común limitado a los países del Cono Sur de América. La concepción del Mercosur, según las declaraciones que le he escuchado, en más de una ocasión, es la de un Mercado Común de Sur A mérica. ${ }^{381}$

A respeito daquela visita, o Embaixador Alfredo Toro Hardy sintetizou os aspectos comerciais das aspirações venezuelanas nas relações com o Brasil. Segundo o embaixador, $80 \%$ dos produtos comprados no estado do Amazonas provinham do sudeste brasileiro e poderiam ser substituídos por produtos venezuelanos. Também a região Nordeste do Brasil poderia constituir um mercado promissor para as exportações venezuelanas, uma vez que estava distante dos principais fluxos de comércio do Mercosul. O autor citou como exemplo a exportação de cerveja Brahma, que era produzida na Venezuela para ser vendida naquela região brasileira. Além disso, a Venezuela buscava se colocar como principal fornecedora de

\footnotetext{
380 Ibid., p. 272.

381 Ibid., p. 297.
} 
energia para o Brasil, ampliando, consideravelmente, as vendas de petróleo. Por fim, o embaixador destacou os potenciais benefícios da associação da Venezuela ao Mercosul, citando o exemplo da Argentina:

Baste citar que tras la constitución del Mercosur, 400 empresas brasileñas se han instalado en Argentina, realizando ingentes inversiones. Para Venezuela, la aproximación al Mercosur resulta una continuación natural de su relación privilegiada con el Brasil. ${ }^{382}$

Uma vez encerradas as visitas, o embaixador Clodoaldo Hugueney informou ao Ministério das Relações Exteriores que elas tiveram "grande e altamente favorável repercussão entre as autoridades e empresários venezuelanos”. Segundo o Embaixador, os venezuelanos tinham quatro planos estratégicos sobre os quais deveriam incidir as relações bilaterais: desenvolvimento sustentável das regiões Sul da Venezuela e Norte do Brasil, integração de infraestrutura e matéria energética, integração entre o Mercosul e a Comunidade Andina mediante as negociações para conformação de uma zona de livre comércio e, finalmente, impacto da integração bilateral sobre as estratégias dos dois países de inserção na economia global. Também a imprensa venezuelana deu grande destaque à iniciativa e apresentou, de forma muito favorável, a visita bilateral, através de matérias de primeira página nos maiores jornais, além de "ampla cobertura nas rádios e nos canais de televisão", segundo informou o Embaixador do Brasil. ${ }^{383}$

Naquele ano, o grupo de trabalho sobre o meio ambiente se reuniu duas vezes. A primeira reunião foi realizada em Caracas, em maio. A outra realizou-se em Brasília, em setembro, e contou com a presença dos Ministros do Meio Ambiente dos dois países. O grupo de trabalho sobre mineração ilegal se reuniu outras duas vezes naquele mesmo ano, havendo a primeira reunião acontecido em maio e a segunda reunião entre os dias 2 e 3 de dezembro. $\mathrm{O}$ objeto dessas reuniões foram as iniciativas de cooperação bilateral para reprimir atividades de mineração ilegal na fronteira, com destaque para a decisão, tomada no segundo encontro, de reativar a Missão Científica de Alto Nível. ${ }^{384}$

Em junho, se reuniu pela sexta vez o Mecanismo Político de Consulta, em Caracas, com a presença do Secretário Geral do Itamaraty, Sebastião do Rego Barros, e se decidiu criar um grupo de trabalho sobre cooperação militar, que não chegou a se reunir até o final de

\footnotetext{
${ }^{382}$ Ibid., p. 19.

383 Telegrama $\mathrm{n}^{\circ}$ 288, 14/04/1997. De Clodoaldo Hugueney Filho, Embaixador do Brasil em Caracas, ao Ministério de Relações Exteriores. Ano 1997 Dig italizado.

${ }^{384}$ Libro Amarillo referente ao ano 1997, p. 139-140.
} 
1998. ${ }^{385}$ Naquela ocasião, a confiança entre as delegações dos dois países já era tão grande que o Diretor-Geral da Chancelaria venezuelana, Carlos Bivero, afirmou ser aquele o Mecanismo Político mais bem sucedido da América Latina. ${ }^{386}$ Ainda naquele mesmo mês, o grupo de trabalho sobre comunicações se reuniu pela primeira vez, na cidade do Rio de Janeiro. Além de temas relativos às comunicações regionais, fronteiriças e de telefonia celular, foi apresentado, pela delegação venezuelana o Projeto Simón Bolívar, através do qual os países da Comunidade Andina coordenariam a utilização de satélites. ${ }^{387}$

Nesse contexto, as autoridades financeiras da Venezuela continuavam se valendo da consultoria brasileira para acelerar as reformas da economia. O próprio Presidente do Banco Central da Venezuela, Antonio Casas, reconheceu que a Agenda Venezuela fora elaborada a partir de consultas com membros do governo brasileiro, que haviam colaborado na concepção do Plano Real. Como se pode notar, após um ano da implementação da Agenda Venezuela, Antonio Casas ainda continuava se consultando com influentes membros da equipe econômica do governo brasileiro, como Gustavo Loyola, Gustavo Franco e o Ministro da Fazenda, Pedro Malan. Nesses encontros Casas reafirmava a determinação de acelerar os processos de privatização dos setores de alumínio, aço e energia elétrica. ${ }^{388}$

Em setembro, reuniu-se o grupo de trabalho sobre desenvolvimento fronteiriço e, nessa ocasião, foi constituído o Conselho Binacional de Integração Empresarial, revitalizando iniciativa que já fora implementada ainda em 1994, quando o mesmo grupo de trabalho instituiu o Conselho Empresarial Binacional do Norte. ${ }^{389}$ No dia 5 de setembro, aconteceu em Boa Vista o I Encontro entre Parlamentares Brasileiros e Venezuelanos que concretizava as negociações dos deputados Paciano Padrón, Presidente da Comissão de Política Exterior da Câmara de Deputados da Venezuela, e Benito Gama, Presidente da Comissão de Relações Exteriores e Defesa Nacional da Câmara de Deputados do Brasil. Os deputados repassaram os temas de cooperação bilateral e analisaram as atas dos grupos de trabalho que versavam sobre os temas mais diversos, como a cooperação fronteiriça, energética, de saúde e o Mercosul. A contribuição desse encontro, mais do que gerar novas propostas, foi a de envolver as

\footnotetext{
${ }^{385}$ Libro Amarillo referente ao ano 1997, p. 139. A referência ao grupo de trabalho sobre cooperação militar pode ser encontrada no Libro Amarillo referente ao ano 1998, p. 445.

386 Telegrama $\mathrm{n}^{\circ}$ 461, 10/06/1997. De Clodoaldo Hugueney Filho, Embaixador do Brasil em Caracas, ao Ministério de Relações Exteriores. Ano 1997 Dig italizado.

387 Libro Amarillo referente ao ano 1997, p. 140.

388 Gazeta Mercantil, 06/08/1997.

${ }^{389}$ Libro Amarillo referente ao ano 1997, p. 140.
} 
instituições parlamentares no processo de aproximação conduzido, não só pelos Presidentes dos dois países, mas por muitos outros atores que contribuíram nesse sentido. ${ }^{390}$

O grupo de trabalho sobre agricultura se reuniu, pela primeira vez, em novembro e nessa reunião foram discutidos projetos de abertura comercial para beneficiar o setor. Cabe destacar, neste caso, a alta capacidade exportadora do Brasil de produtos agrícolas e a cond ição de importadora desses produtos por parte da Venezuela. ${ }^{391}$ Também naquele mês, a imprensa venezuelana noticiou medidas econômicas adotadas pelo governo brasileiro para garantir a continuidade do plano de estabilização. A cobertura feita pelos veículos de comunicação sobre essa questão foi favorável ao governo do Brasil: enfatizava a "severidade" das medidas e a coragem de realizá-las já às vésperas de um ano eleitoral. Dessa forma, estabeleceu-se uma rede de apoio às reformas neoliberais. Por um lado, a imprensa brasileira cobria positivamente o avanço das reformas na Venezuela e, por outro, a imprensa venezuelana fazia o mesmo em relação à política econômica do governo brasileiro, apoiada em informações distribuídas pela Embaixada do Brasil. ${ }^{392}$

A sexta reunião da COBAN aconteceu nos dias 8 e 9 de dezembro, quando o Chanceler Venezuelano, Burelli Rivas, realizou visita oficial ao Brasil, acompanhado do Ministro de Indústria e Comércio, Freddy Rojas Parra. Retribuindo o tratamento que o Minis tro brasileiro recebeu em Caracas no ano anterior, o presidente Fernando Henrique Cardoso recebeu pessoalmente os ministros venezuelanos. Um dos objetivos prioritários daquela visita era a reiteração do compromisso dos dois governos com a celebração de um acordo de livre comércio entre a Comunidade Andina e o Mercosul, além da negociação de iniciativas conjuntas no setor energético entre as estatais Petrobras e PDVSA. ${ }^{393}$

Antes ainda de se encerrar aquele ano, foi realizado, na Venezuela, o leilão de privatização da empresa Siderúrgica do Orenoco (Sidor): o consó rcio vencedor contou com a participação da empresa brasileira Usiminas. Dentre os dois outros consórcios que concorreram, um deles tinha a participação de outra empresa brasileira, a Companhia Siderúrgica Nacional. A potencialização das chances de sucesso de empresas brasileiras em

\footnotetext{
390 Telegrama n 687, 15/09/1997. De Ministério de Relações Exteriores para Embaixada do Brasil em Caracas. Ano 1997 Digitalizado.

${ }^{391}$ Libro Amarillo referente ao ano 1997, p. 140.

392 Telegrama $n^{\text {o } 894, ~ 11 / 11 / 1997 . ~ D e ~ C l o d o a l d o ~ H u g u e n e y ~ F i l h o, ~ E m b a i x a d o r ~ d o ~ B r a s i l ~ e m ~ C a r a c a s, ~ a o ~}$ Ministério de Relações Exteriores. Ano 1997 Dig italizado.

${ }^{393}$ Libro Amarillo referente ao ano 1997, p. 326-327.
} 
leilões de privatização na Venezuela era um dos objetivos permanentes das autoridades brasileiras em suas iniciativas de aproximação política e comercial. Portanto, não foi por outro motivo que o resultado do leilão da Sidor foi recebido, no Brasil, como uma vitória e um fruto daquela estratégia. 394

\subsubsection{8: eleições desviam atenção das relações bilaterais}

Em 1998, ano eleitoral nos dois países, a cooperação bilateral ficou relegada a segundo plano porque as eleições consumiram todo o tempo e esforços da classe política. Por essa razão, os encontros e visitas foram sensivelmente reduzidos, em comparação com os anos anteriores. Ainda assim, aconteceu a sétima reunião do Mecanismo Político de Consulta e também uma visita dos Presidentes à cidade fronteiriça de Santa Elena de Uairén, carregada de simbolismo porque nela aconteceu, em 1973, no final do mandato de Rafael Caldera, o encontro com o presidente Médici. Anos depois, nesse mesmo local, ocorreu novo encontro com presidentes do Brasil e da Venezuela.

Nesse novo momento, o Brasil era governado por Fernando Henrique Cardoso, que gozava de considerável popularidade devido à estabilização da economia, mas na Venezuela tinha início a campanha presidencial que substituiria Rafael Caldera, impossibilitado de se reeleger de acordo com a Constituição do país.

Durante o processo eleitoral venezuelano, a crise provocada no país pelo aumento do preço do petróleo começara a se reverter o que contribuía para diminuir as tensões sociais e políticas. 395

Em março, a imprensa brasileira começou a priorizar, em suas notícias, o desenrolar da campanha presidencial no país vizinho. Com as eleições marcadas para dezembro daquele ano, os principais candidatos já mobilizavam eleitores, apoiadores e financiadores. O précandidato do Copei era Eduardo Fernández: ele já havia concorrido contra Carlos Andrés

\footnotetext{
394 Telegrama $n^{\circ}$ 1017, 18/12/1997. De Clodoaldo Hugueney Filho, Embaixador do Brasil em Caracas, ao Ministério de Relações Exteriores. Ano 1997 Dig italizado.

395 Telegrama no 91, 06/02/1998. De Clodoaldo Hugueney Filho, Embaixador do Brasil em Caracas, ao Ministério de Relações Exteriores. Ano 1998 Dig italizado.
} 
Pérez, em 1988, com uma plataforma abertamente neoliberal que ele adotaria uma década depois. Ele era o candidato mais próximo das autoridades brasileiras e foi recebido naquele mês pelo vice-presidente Marco Maciel, pelo governador do Distrito Federal Cristovam Buarque e pelo secretário-geral do Itamaraty Sebastião do Rego Barros por insistência do Embaixador brasileiro. Naquela ocasião, o pré-candidato aproveitou para lembrar às autoridades brasileiras da afinidade de sua candidatura com a de Fernando Henrique Cardoso, ambas apoiadas por "forças liberais". ${ }^{396}$ No entanto, apesar dessa afinidade, a candidatura de Fernández não se concretizou.

Hugo Chávez, líder das rebeliões de 1992 que passara dois anos preso e fora anistiado em 1994, apresentou-se como pré-candidato: crescia nas pesquisas com um discurso que rejeitava a esquerda e a direita, o socialismo e o neoliberalismo, em favor de uma ideologia que ele denominava "bolivariana". Chávez procurou ser recebido pelos representantes da Embaixada do Brasil em Caracas, mas não foi recebido. ${ }^{397}$ Naquele momento, quem liderava as pesquisas era a ex-miss universo Irene Sáez, que se apresentava como candidata independente, beneficiando-se junto ao eleitorado pelo seu distanciamento com relação aos principais partidos políticos, embora se declarasse fã de Margareth Tatcher e do neoliberalismo. ${ }^{398}$

O crescimento das intenções de voto em Hugo Chávez se explica pelo fato de ser identificado como o candidato que mais rejeitava o neoliberalismo, apesar de seguidas declarações nas quais buscou matizar suas posições. Em decorrência de sua posição privilegiada na disputa eleitoral, a imprensa brasileira passou a centralizar suas reportagens nessa candidatura, procurando denegrir a imagem de Chávez. A estigmatização do candidato fica evidente no seguinte trecho de autoria Carlos Alberto Montaner publicado numa coluna de $O$ Estado de S. Paulo:

Se fosse possível moer, numa máquina, Perón e Velasco Alvarado, Noriega e Che Guevara, Daniel Ortega e Fidel Castro, Abimael Guzmán e o padre Pérez da guerrilha colombiana, e essa massa fosse polvilhada com uma pitada de Kadafi e salpicada com u mas gotas de Saddam Hussein, es taríamos construindo Hugo Chávez - um sujeito que resume, assimila e repete todos os erros e barbaridades que durante

\footnotetext{
${ }^{396}$ Correio Braziliense, 23/03/1998. Telegrama no 117, 11/02/1998. De Clodoaldo Hugueney Filho, Embaixador do Brasil em Caracas, ao Ministério de Relações Exteriores. Ano 1998 Digitalizado. Telegrama ${ }^{\circ}{ }^{195}$, 20/03/1998. De Ministério das Relações Exterio res à Embaixada do Brasil em Caracas. Ano 1998 Digitalizado. ${ }^{397}$ Jornal do Brasil, 08/12/1998.

${ }^{398}$ Jornal do Brasil, 13/03/1998. O Estado de S. Paulo, 29/03/1998.
} 
o século 20 empobreceram, confundiram e atrasaram a América Latina, com assombroso sadismo. ${ }^{399}$

Também era comum que os jornais brasileiros se referissem a Hugo Chávez como golpista, em alusão à sua participação nas rebeliões de 1992, e como populista. Esse último termo também era aplicado ao ex-presidente Carlos Andrés Pérez como sinônimo de demagogo. ${ }^{400}$ A respeito da utilização política dessa expressão, Maria Helena Rolim Capelato afirmou:

Nos últimos tempos, o termo populis mo deslizou do campo acadêmico para o terreno político, apresentando, então, conotação dicotômica e maniqueísta. Dessa forma, ganha sentido positivo ou pejorativo, dependendo do grupo que o mobiliza no debate público. Usado como arma de luta a favor do neoliberalis mo, o ataque ao populismo contribuiu para a construção de imaginários políticos que serviam aos interesses de novos grupos de poder. ${ }^{401}$

Em abril, aconteceu em Brasília a sétima reunião do Mecanismo Política de Consulta, na qual foram avaliados os relatórios dos grupos de trabalho: os resultados foram considerados satisfatórios. As delegações decidiram reativar o grupo de trabalho sobre planejamento e criar o grupo de trabalho encarregado de assuntos sociais.

O Vice-Ministro das Relações Exteriores da Venezuela chefiou a delegação de seu país e manteve encontro com o chanceler Luiz Felipe Lampreia. Ambos conversaram, naquela reunião, sobre as negociações para integração da Comunidade Andina e do Mercosul e também sobre as negociações para implementação de projetos conjuntos entre a PDVSA e a Petrobras, assunto que o Chanceler brasileiro considerou tão importante quanto o primeiro, em comunicado que, posteriormente, enviou à Embaixada do Brasil. ${ }^{402}$ A propósito deste último objetivo Lampreia escreveu em sua autobiografia que nunca manteve "ilusões" a respeito desse projeto uma vez que a estatal venezuelana não demonstrava interesse em negociar com o Brasil, priorizando sempre as negociações com os Estados Unidos. ${ }^{403}$

O grupo de trabalho sobre planejamento se reuniu entre os dias 8 e 9 de junho e propôs à COBAN que se formasse um Centro Binacional de Assuntos Estratégicos para consolidar a

\footnotetext{
399 O Estado de S. Paulo, 05/04/1998.

400 Jornal do Brasil, 04/05/1998.

401 CAPELATO, Maria H. R. "Populismo latino-americano em discussão". In: FERREIRA, Jorge. (org.) $O$ populismo e sua história. Rio de Janeiro: Civilização Brasile ira, 2001, p. 141.

${ }^{402}$ Libro Amarillo referente ao ano 1998, p. 201. Telegrama n ${ }^{\circ}$ 250, 10/04/1998. De Ministério das Relações Exteriores à Embaixada do Brasil em Caracas. Ano 1998 Digitalizado.

403 LAMPREIA, op. cit., p. 225-226.
} 
união entre os dois países que tinham afinidade política; a afinidade consistia na adoção do modelo neoliberal de desenvolvimento. ${ }^{404}$

Por ocasião dos festejos da Independência venezuelana, celebrados no dia 5 de julho, o Ministro da Presidência da Venezuela, José Guilhermo Andueza visitou Brasília, onde inaugurou uma estátua do prócer Simón Bolívar em frente à Embaixada de seu país. Na cerimônia de inauguração da estátua estiveram presentes, além de Maciel, o governador Cristovam Buarque e "vários representantes do corpo diplomático e altas autoridades civis e militares". Nessa ocasião, o Ministro venezuelano manteve encontros reservados com o vicepresidente Marco Maciel nos quais foram avaliados o andamento dos projetos conjuntos. ${ }^{405}$

Meses depois foram realizadas eleições presidenciais no Brasil e Fernando Henrique Cardoso se reelegeu no primeiro turno, com $53 \%$ dos votos, graças ao sucesso obtido no combate à inflação. No entanto, para garantir a reeleição, o governo adiou a desvalorização cambial que se fazia necessária para reduzir os contínuos déficits comerciais.

Após as eleições, os presidentes do Brasil e da Venezuela se reuniram na cidade venezuelana de Santa Elena de Uairén, no dia 23 de novembro e avaliaram, positivamente, os avanços logrados durante os cinco anos de mandato de Caldera, que estava se encerrando. Aquele encontro marcou a inauguração da estrada BR-174 (asfaltada) e os presidentes destacaram os logros obtidos com a integração em termos de infraestrutura (como foi o caso da estrada que ligava Caracas a Manaus, passando por Boa Vista), mas também econômica, energética e cultural. Foi então assinada a Declaração de Santa Elena de Uairén: nesse documento, além das congratulações pela conclusão das obras da estrada, foi mencionada pela primeira a disputa fronteiriça da Venezuela com a Guiana. Rafael Caldera incluiu na Declaração um pedido para que o Brasil sempre se recordasse do direito venezuelano. ${ }^{406}$

A adesão da Venezuela às negociações com o FMI não pode garantir a superação da crise econômica, aprofundada pela diminuição dos preços do petróleo e pelo contágio das crises financeiras que eclodiram na Ásia e na Rússia. O descontentamento popular acabou se manifestando na vitória de Hugo Chávez, no dia 6 de dezembro, com 56.2\% dos votos.

\footnotetext{
${ }^{404}$ Ididem. p. 223.

405 Telegrama n ${ }^{\circ}$ 538, 28/07/1998. De Ministério das Relações Exteriores à Embaixada do Brasil em Caracas. Ano 1998 Digitalizado.

${ }^{406}$ Libro Amarillo referente ao ano 1998, p. 502. A Declaração se encontra reproduzida nas páginas 808-809.
} 
Frente a esse resultado, a imprensa brasileira publicou análises sobre as expectativas concernentes às relações bilaterais depois da posse do novo governo, que ocorreria em fevereiro de 1999.

O Jornal do Brasil comentou que, durante toda a campanha, o único elogio que Chávez fez à administração de Rafael Caldera dizia respeito a sua política de aproximação com o Brasil. O Correio Braziliense noticiou que o presidente eleito havia escolhido o Brasil como o primeiro país a ser visitado por ele e, segundo o jornal, a Câmara de Comércio BrasilVenezuela anunciara que Hugo Chávez faria uma palestra a empresários brasileiros ainda naquele ano. O Correio reproduziu também a seguinte afirmação do chanceler Luiz Felipe Lampreia: "O presidente eleito tem reiterado a intenção de manter e aprofundar a aproximação com o Brasil, iniciada com o presidente Rafael Caldera, algo que certamente o governo brasileiro vê com bons olhos". 407

A Folha de S. Paulo ouviu os deputados federais Roberto Campos e Aloizio Mercadante sobre as suas expectativas em relação ao governo de Hugo Chávez. Roberto Campos, que fora Ministro da ditadura militar e era identificado com o neoliberalismo, previu catástrofe para a Venezuela caso Chávez tentasse, efetivamente, implementar sua plataforma populista. Mas lembrou, com alívio, que também Carlos Menem fora eleito na Argentina com um discurso semelhante, mas acabara se tornando o campeão do neoliberalismo. E concluiu que o liberalismo não era o problema da América Latina, e sim a solução.

Aloizio Mercadante, membro do Partido dos Trabalhadores, que fazia oposição às políticas neoliberais do governo Cardoso, também não festejou a vitória de Hugo Chaves, mas seu argumento ia noutra direção. Temia pelo destino da democracia na América do Sul e, neste sentido, afirmou:

A democracia foi uma conquista muito difícil na região. Devido à tentativa de golpe
de 1992, ele gera insegurança em relação a esse valor fundamental. (...) Precisamos
construir alternativas que não sejam baseadas no populismo econômico e no
voluntaris mo autoritário. 408

Para concluir, recorremos ao Libro Amarillo publicado no início de 1999 e que continha uma revisão das principais iniciativas diplomáticas da Venezuela durante o quinquênio em que Rafael Caldera foi Presidente. A característica particular das relações

\footnotetext{
407 Jornal do Brasil, 08/12/1998. Correio Braziliense, 08/12/1998.

${ }^{408}$ Folha de S. Paulo, 08/12/1998.
} 
bilaterais daqueles anos, como mencionado anteriormente, foi a articulação em torno de instâncias hierarquizadas: os grupos de trabalho, as reuniões do Mecanismo de Consulta Política, as reuniões da COBAN e as reuniões presidenciais. Naquela edição do Libro Amarillo, foi publicado um breve relatório dos resultados que a Chancelaria venezuelana considerou como sendo os principais logros da cooperação bilateral que analisamos.

A institucionalização das relações no período analisado neste capítulo final (19941998) possibilitou a redução dos confrontos na fronteira entre os garimpeiros e as forças de segurança nos dois países; o aumento do comércio bilateral de petróleo e gás, exportados da Venezuela para o Brasil; a assinatura de um contrato de venda de energia elétrica das usinas venezuelanas para o estado de Roraima; o incremento da cooperação para desenvolvimento de atividades econômicas na região de fronteira; a celebração de um Acordo de Promoção e Proteção Recíproca de Investimentos e o início de negociações para a adesão da Venezuela ao Mercosul e para a formação de uma zona de livre-comércio sul-americana. 


\section{CONSIDERAÇÕES FINAIS}

A análise das fontes evidencia uma aproximação política inédita no registro das relações bilaterais: o Brasil e a Venezuela mantiveram, durante quinze anos (1983 - 1998) uma intensa cooperação intensa em vários planos. Concordamos, portanto, com Amado Cervo quando afirma que: "nenhum outro país da América do Sul apresenta, relativamente ao Brasil, no início do milênio, tantas variáveis comuns em sua visão de mundo e em sua estratégia externa quanto a Venezuela". ${ }^{409}$

No entanto, cabe ressaltar que tais afinidades não se manifestaram de forma linear. Ao contrário, as relações nesse período foram constantemente influenciadas por circunstâncias adversas, como foi mostrado ao longo do texto. No primeiro capítulo procuramos demonstrar que a criação de um clima de confiança teve que enfrentar desconfianças históricas. A primeira delas se baseava no que os venezuelanos entendiam como tendências militaristas e expansionistas do Brasil, tendências essas que teriam se acentuado a partir do regime militar que manifestava interesse em relação à região amazônica; a segunda estava relacionada à tradição de proselitismo democrático dos venezuelanos, reforçada na imprensa brasileira que, no início do processo de redemocratização no Brasil, citava o país vizinho como modelo de cultura democrática a ser seguido pelos brasileiros na luta contra a ditadura ainda vigente no país.

O fato de a Venezuela ter se diferenciado de outros países da região que viveram sob regimes autoritários permitiu que se formassem laços entre a elite governante venezuelana, particularmente os membros do partido da Ação Democrática e líderes da oposição brasileira à ditadura, como Ulysses Guimarães, um dos fundadores do MDB, Fernando Henrique Cardoso e Leonel Brizola.

Dentre os fatores que favoreceram a aproximação, cabe destacar, com base no que foi exposto no primeiro capítulo, a adesão da diplomacia brasileira às iniciativas prevalecentes na América Latina no que dizia respeito às questões de segurança. A partir dos anos finais da ditadura militar, foi sendo desfeita, gradualmente, a imagem do Brasil como potência agressiva e alinhada com os Estados Unidos. Para que isso fosse possível, contribuíram muito

${ }^{409}$ CERVO, A mado L. “A Venezuela e seus vizinhos”. In: GUIMARÃES; CARDIM. op. cit, p 173. 
o apoio às reivindicações argentinas em relação às Ilhas Malvinas e também a participação do Brasil no Grupo de Apoio a Contadora, criado para a prevenção de ações militares dos Estados Unidos contra o governo revolucionário da Nicarágua. As posições brasileiras a respeito desses temas coincidiam com as posições venezuelanas, e tal coincidência contribuiu para a criação de expectativas positivas de cooperação futura.

A cooperação em matéria de segurança não se verificou quando se colocou a questão da crise da divida externa enfrentada pelos dois países. Ela incidiu, tanto sobre o Brasil como sobre a Venezuela: teve a mesma origem e através da mesma dinâmica. Em que pesem as diferenças entre os modelos de desenvolvimento adotados pelos dois países durante as décadas anteriores, eles compartilhavam, como a maioria dos países da América Latina, a dependência em relação ao financiamento externo, obtido mediante empréstimos contratados a taxas de juros flutuantes, condicionadas a taxas praticadas nos países centrais. A elevação dessas taxas de juros incidiu de igual maneira sobre as dívidas do Brasil e da Venezuela e inviabilizou, nos do is casos, a continuidade do desenvolvimento.

Procuramos mostrar que a crise da dívida na América Latina acabou inspirando propostas de coordenação política entre os países devedores para que forçassem a renegociação das dívidas contratadas juntos aos grandes bancos internacionais. Tais propostas não encontraram maior acolhida entre os dirigentes políticos brasileiros que, quando recorreram à moratória, em 1987, optaram por não politizar o evento. Do lado venezuelano, houve maior aceitação às teses de coordenação entre os países endividados defendida especialmente por Carlos Andrés Pérez nos anos anteriores à sua eleição para um segundo mandato.

No entanto, os limites para a cooperação em matéria da dívida externa não impediram que o saldo político da década fosse positivo para a integração entre os dois países: houve um estreitamento das relações concretizado durante a visita de José Sarney a Caracas, em 1987. Por essa razão, concluímos que o processo político da década de oitenta foi tão importante para a proximidade dos dois países como a que ocorreu nos anos finais do século a partir do encontro da Guzmania ocorrido em 1994. Esse encontro, segundo pudemos observar, foi celebrado exageradamente como o início de uma nova fase na história das relações entre os 
dois países. ${ }^{410}$ Ao contrário, procuramos mostrar que ele já vinha ocorrendo, de forma significativa, na década anterior.

No segundo capítulo, abordamos as questões relacionadas ao segundo mandato de Carlos Andrés Pérez e ao breve governo de Fernando Collor de Mello.

A eleição de Carlos Andrés Pérez, que propôs uma reforma econômica radical e impopular já no início de seu segundo mandato, precedeu em apenas um ano a eleição de Fernando Collor de Mello, no Brasil. O novo Presidente brasileiro, assim como o seu homólogo venezuelano, procurou mudar o paradigma de desenvolvimento da economia brasileira para um modelo inspirado nas recomendações do governo dos Estados Unidos e do Fundo Monetário Internacional. Ambos os Presidentes vivenciaram mandatos turbulentos, caracterizados pela agudização da crise política, contaminada pela crise econômica. Também com relação às políticas econômicas dos dois governantes e os resultados delas, apontamos similaridades. A comparação se torna mais evidente a partir dos desfechos: nenhum deles conseguiu concluir seus mandatos. A desestabilização política doméstica que ocorreu tanto na Venezuela como no Brasil, acabou desestimulando o adensamento das relações durante um período, tal como foi relatado nesse mesmo capítulo.

Entre 1989 e 1992 ocorreram as primeiras tentativas de adesão ao paradigma neoliberal nos dois países como já mencionamos. Mas existiram importantes diferenças entre o processo brasileiro e o processo venezuelano. No que se refere à Venezuela, a perda de legitimidade do governo de Carlos Andrés Pérez foi tão pronunciada que inviabilizou qualquer nova iniciativa diplomática. No ano crítico de 1992, o Presidente foi até mesmo proibido pelo Senado de viajar para o exterior. Já no Brasil, o presidente Collor pode concretizar a formação do Mercosul. É possível afirmar, portanto, que a desaceleração da integração entre o Brasil e a Venezuela naquele começo dos anos 1990 foi causada mais pelas dificuldades políticas e econômicas enfrentadas pelos venezuelanos do que pela crise política brasileira que não afetou de forma particular a atuação da diplomacia.

Outro contraste importante entre os dois países se refere à maneira como cada um dos presidentes se vinculou ao projeto neoliberal. Fernando Collor de Mello construiu o discurso de sua campanha a partir da promessa de modernizar o país, o que significava entrosamento

\footnotetext{
${ }^{410}$ LOSS, op. cit., p 82. EMBAIXADA DA VENEZUELA NO BRASIL, op. cit.
} 
com os interesses do capitalismo internacional. Sua candidatura se opôs à de Luis Inácio Lula da Silva, que adotou uma plataforma ostensivamente crítica ao programa neoliberal e à adesão dos negociadores brasileiros aos critérios dos credores externos no que dizia respeito ao problema da dívida.

Carlos Andrés Pérez, diferentemente, adotou um discurso dúbio em relação ao neoliberalismo e às negociações da dívida externa. Seu histórico de liderança popular em seu país revelava um político de inclinações nacionalistas porque nacionalizara as atividades relacionadas ao petróleo e ao ferro durante o seu primeiro mandato como Presidente da Venezuela, entre 1974 e 1979. Ao longo da década de 1980, Pérez deu seguidas declarações nas quais rechaçava a intromissão do FMI no planejamento das políticas econômicas dos países devedores. À medida que se aproximavam as eleições de 1988, ele moderou o seu discurso, fazendo referências ocasionais à necessidade de "desestatizar" a economia e de fortalecer a iniciativa privada. Uma vez empossado, o novo presidente lançou mão de um grande pacote de reformas claramente alinhadas com as teses neoliberais e interesses dos bancos credores.

Assim, ainda que concordemos com Amado Cervo quando afirma que os dois países foram "exemplos de hesitações políticas e tropeços operacionais" na aplicação do programa neoliberal, ${ }^{411}$ procuramos mostrar no segundo capítulo que os tropeços foram mais recorrentes do que as hesitações. Fernando Collor não hesitou em aderir ao receituário neoliberal e Carlos Andrés Pérez também aderiu rapidamente depois de eleito.

Amado Cervo afirma que o momento neoliberal na América Latina significou o abandono dos "interesses nacionais" revelado por uma atitude de submissão ideológica por parte dos governantes. ${ }^{412}$ Acreditamos que é preciso nuançar essa afirmação, pois tanto os presidentes Carlos Andrés Pérez e Rafael Caldera até o agravamento da crise da dívida se

411 CERVO, Amado L. Relações Internacionais na América Latina: velhos e novos paradigmas. 2. Ed. São Paulo: Saraiva, 2007, p. 216.

${ }^{412}$ Esse tipo de interpretação está particularmente presente também em outras obras do autor, como CERVO, Amado L. "Relações Internacionais do Brasil". In: CERVO, A mado L. (org.) O Desafio Internacional: a política exterior do Brasil de 1930 a nossos dias. Brasília: Ed. Un B, 1994, p. 9-58., e também CERVO, A mado L. "A ação internacional do Brasil em um mundo em transformação". In: OLIVEIRA, Henrique A.; LESSA, Antonio C. (orgs.) Relações Internacionais do Brasil: temas e agendas. São Paulo: Saraiva, 2006, p. 7-34. Em outro texto, contudo, o autor se refere à mudança de paradigma de forma menos depreciativa, reconhecendo no neoliberalis mo a existência de uma proposta de desenvolvimento alternativa ao nacional-desenvolvimentis mo: CERVO, Amado L. "O final do século XX e o início do XXI: dificuldades para construção de uma ordem global”. In: SARAIVA, op. cit., p. 317-340. 
definiam, claramente, contra o neoliberalismo. Essa posição se sustentava porque a dependência em relação aos bancos fora minimizada em seus efeitos mais drásticos durante suas gestões nos anos 1970, quando o petróleo se valorizou. Quando voltaram ao poder, duas décadas depois, a situação era outra: as exportações de petróleo já não apresentavam os mesmos rendimentos e os capitais internacionais já não tinham a mesma disponibilidade. Incapacitados de coordenar uma nova elevação dos preços do petróleo junto à OPEP, o recurso ao FMI tornou-se inevitável para a retomada dos fluxos financeiros que emanavam do sistema bancário internacional.

Recorremos às análises de Pierre Renouvin e Jean-Baptiste Duroselle para dar suporte à nossa conclusão sobre as reformas neoliberais que se diferencia daquela apresentada por Amado Cervo. Este autor enfatiza a importância da subserviência ideológica dos atores em relação às coordenadas neoliberais impostas de fora sem levar em conta o peso das "forças profundas" (conceito formulado por Renouvin e Duroselle) ou seja, do sistema econômico internacional assentado sobre a propriedade privada dos ativos financeiros. Procuramos mostrar que os governantes venezuelanos, ao invés de traírem seus ideais, não puderam oferecer alternativas ao neoliberalismo. Podemos afirmar, a partir do que foi exposto no segundo e terceiro capítulo, que as reformas neoliberais, embora tenham sido aplicadas nos dois países no mesmo período, evidenciaram diferenças ideológicas importantes entre as autoridades da Venezuela e do Brasil em relação à adoção da política neoliberal. Concluímos, portanto, que não foram as crenças dos atores nas reformas que definiram a sua concretização, mas sim fatores externos à vontade deles.

A maioria dos autores reconhece a importância da influência externa na decisão sobre a aplicação das reformas neoliberais e Amado Cervo também reconhece esse dado, mas sem retirar dele todas as suas consequências. Quando nos referimos à determinação externa, temos clareza de que o programa neoliberal foi gestado em território estrangeiro, em universidades e institutos sediados nos países centrais do sistema econômico mundial, mas também levamos em conta o fato de que a capacidade dos atores para elaborar um programa alternativo tem como limite as regras básicas do sistema capitalista: entre outras, o respeito aos contratos. Os contratos de empréstimo firmados com os bancos internacionais na década de 1970 previam a possibilidade de elevação dos juros. 
Os dirigentes buscavam soluções para a crise decorrente das "forças profundas" porque delas dependia a legitimidade dos governos. No entanto, as soluções não eram necessariamente coincidentes com o bem estar da maioria da população, como mostraram nossas fontes e também como reconheceu Amado Cervo.

Reconhecer essa realidade é uma consequência lógica do trabalho desenvolvido ao longo dos três capítulos. Mas tal reconhecimento não implica minimizar ou recusar a capacidade dos atores se movimentarem com algum grau de liberdade no interior das "forças profundas", pois como também procuramos mostrar nesses capítulos, a aproximação entre o Brasil e a Venezuela foi se gestando gradualmente ao longo dos anos até conquistar uma institucionalidade gerada pelos grupos de trabalho compostos por atores diversos, desde funcionários e técnicos até os Presidentes. A aproximação entre os dois países não foi, portanto, imposta pelas "forças profundas", mas sim um resultado da interação entre elas e as estratégias dos tomadores de decisão.

Ao longo da década de 1980 foi se formando, nos dois países, uma vontade política de maior integração. Essa vontade política foi testada pelas crises e pelas reformas e resistiu, evidenciando a capacidade de iniciativa dos dois países, mesmo em um contexto adverso.

Tal processo integracionista se cristalizou a partir dos eventos relatados no terceiro capítulo: eles permitiram demonstrar a afinidade entre as principais iniciativas de cooperação e os objetivos de desenvolvimento econômico. A existência dos grupos de trabalho voltados para o comércio e também para a integração logística, tecnológica e financeira, bem o demonstram e o mesmo pode se dizer em relação às negociações para a complementação energética e de infraestrutura.

No entanto, ao mesmo tempo em que esses projetos demonstraram capacidade de iniciativa relativamente autônoma da política externa dos dois países. Eles também foram limitados por forças maiores, como a integração prévia com os mercados centrais. O bloqueio à maior cooperação entre a PDVSA e a Petrobrás é um exemplo dessa limitação, como reconheceu o chanceler Luiz Felipe Lampreia.

As relações entre os dois países permaneceram bastante dependentes dos esforços governamentais e relativamente fechadas à participação de setores mais amplos da sociedade civil. A imprensa desempenhou papel importante, dos dois lados da fronteira, oferecendo a 
um público mais amplo interpretações sobre o significado das relações de maneira autônoma em relação às versões oficiais. A imprensa venezuelana, no geral, oscilou entre interpretações negativas quando se tratava de expor temores em relação ao expansionismo brasileiro, e positivas, no caso do apoio ao programa de estabilização da economia. A imprensa brasileira deu grande cobertura à crise política venezuelana, revelando uma preocupação pedagó gica a ser captada pelos governantes do Brasil. Nos anos finais da década de 1990, todas as reportagens que se referiam, especificamente, às relações bilaterais foram feitas de maneira elogiosa, destacando a assistência conferida pelas autoridades monetárias brasileiras a seus homólogos venezuelanos, como foi destacado no terceiro capítulo.

Também o empresariado foi convocado pelos governos a assumirem um papel mais destacado na condução da integração. A correspondência diplomática brasileira revela especial atenção dos Embaixadores em relação às oportunidades de negócios surgidas na Venezuela para os setores de empresas públicas e privadas. A partir de 1995 se intensificaram os encontros empresariais bilaterais incentivados pela diplomacia e sempre prestigiados por altas autoridades como Ministros e Presidentes.

No que se refere aos partidos políticos, verificou-se que no período em que o MDB fez oposição à ditadura militar, as relações com partidos venezuelanos foram mais profícuas. A mudança de regime no Brasil implicou também transformações no perfil da oposição, que desde 1989 foi mais bem representada pelo Partido dos Trabalhadores, que não estabeleceu comos venezuelanos laços de proximidade similares aos que Ulysses Guimarães teve com os políticos da Ação Democrática nos primeiros anos da década. No final do terceiro capítulo, procuramos deixar evidente o distanciamento do PT em relação à política venezuelana quando mencionamos as declarações críticas de Aloízio Mercadante sobre a eleição de Hugo Chávez.

Algumas ausências também são reveladoras no que se refere ao processo de integração. Ao longo da pesquisa, tomamos conhecimento da alta incidência de conflitos na região de fronteira envolvendo garimpeiros e indígenas. Muitas reuniões foram feitas para discutir essa questão, como mencionamos no terceiro capítulo. No entanto, em nenhuma delas registrou-se a presença de qualquer representante das comunidades indígenas, as mais afetadas pelas decisões que foram tomadas pelos governantes a partir dessas reuniões.

Esperamos, com este trabalho, contribuir para o debate sobre o tema das relações bilaterais entre os países da América Latina. Especificamente, buscamos demonstrar que a 
proximidade registrada entre o Brasil e a Venezuela durante o período em que governaram Hugo Cháveze Lula teve sólidos antecedentes, marcando uma relação concebida e construída através de momentos e propósitos bastante variados. Não subsiste, portanto, certa interpretação dessas relações que atribui a proximidade entre os dois países na primeira década do século XXI apenas à proximidade ideológica entre Chávez e Lula. 


\section{FONTES}

No Arquivo Histórico do Ministério das Relações Exteriores do Brasil, foram consultadas as correspondências trocadas entre a Embaixada do Brasil em Caracas e a sede do Minis tério em Brasília, durante o período que se estende desde o ano de 1983 até o ano 1998.

Na Hemeroteca do Senado Federal foram consultadas as reportagens publicadas na imprensa brasileira sobre a Venezuela, no período que se estende desde 1977 ao ano 1999. Os jornais são: Folha de São Paulo, Jornal do Brasil, Jornal de Brasília, Correio Brasiliense, Estado de São Paulo, O Globo, Gazeta Mercantil, Tribuna da Imprensa e Jornal da Tarde.

Em Caracas, pudemos visitar a biblioteca do Ministério das Relações Exteriores da Venezuela, onde consultamos os Libros Amarillos, que são relatórios anuais elaborados pelo Ministério, e cujo conteúdo principal consiste nas atas de reuniões, textos de acordos e reprodução de discursos das autoridades do país em visitas bilaterais e fóruns multilaterais. Os relatórios consultados referem-se a todos os anos compreendidos entre 1981 até 1999. Também na mesma biblioteca foram consultados todos os números da Revista Política Internacional, publicada pelo Ministério trimestralmente entre os anos de 1986 e 1998.

Foram realizadas também quatro entrevistas em Caracas. Estas entrevistas buscaram documentar a experiência vivida por profissionais que desempenharam atividades relevantes durante o período sobre o qual se apoia nosso estudo. O primeiro entrevistado foi o Prof. Dr. Alejandro Mendible, professor de História do Brasil na Universidade Central da Venezuela, atual coordenador do departamento de pós-graduação em ciências humanas daquela universidade. O Prof. Mendible possui larga experiência no estudo e ensino da história política brasileira, tendo representado a academia venezuelana em seminário temático realizado pelo Itamaraty, em 1995, na cidade de Brasília. Por indicação do Prof. Mendible, pudemos entrevistar os diplomatas Jesús Mazzei Alfonzo, que foi editor da Revista Política Internacional e também serviu como adido político na Embaixada venezuelana em Brasília entre os anos de 1996 a 2000, e José Bruzual, que desempenhou a mesma função na Embaixada entre os anos de 2000 a 2004. Por fim, coletamos a entrevista da Prof ${ }^{a}$. Beatriz Demoly, brasileira que reside em Caracas desde 1978, havendo-se incorporado ao Instituto Cultural Brasil-Venezuela como professora de português em 1998. 
Nos portais acadêmicos Mundorama e Scielo pudemos consultar todos os números da Revista Brasileira de Política Internacional (RBPI) publicados entre os anos de 1983 e 1998. À semelhança da revista venezuelana, a RBPI publicou artigos e documentos emanados de autoridades e acadêmicos que refletiram o estado de opinião no momento de sua publicação. 


\section{BIBLIOGR AFIA}

ALBUQUERQUE, José A. G. (org.). Sessenta anos de política externa brasileira (19301990). Diplomacia para o desenvolvimento. São Paulo: Cultura Editores/Nupri-USP, V. II, 1996.

. Sessenta Anos de Política Externa Brasileira 1930-1990. Vol. III. O Desafio Geoestratégico. São Paulo: Annablume/NUPRI/USP, 2000

Sessenta anos de política externa brasileira (1930-1990): Prioridades, atores e políticas. São Paulo: Annablume / NUPRI/USP, 2000. V. 4.

ALMADA, Izaías. Venezuela: Povo e Forças Armadas. São Paulo: Caros Amigos, 2007.

ALMEIDA, Paulo R. “A nova história diplomática”. In: Revista Política Externa. Vol. 1, n², Setembro 1992.

O estudo das relações internacionais do Brasil. São Paulo: Unimarco Editora, 1999.

Os primeiros anos do século XXI: O Brasil e as relações internacionais contemporâneas. São Paulo: Paze Terra, 2002.

ARAÚJO, Heloisa V. de (org.). Os Países da Comunidade Andina. Brasília: Fundação Alexandre de Gusmão: Instituto de Pesquisa de Relações Internacionais, 2004.

ARTEAGA S., Rosalia. A Organização do Tratado de Cooperação Amazônica (Otca): um desafio permanente. Diplomacia, Estratégia e Política. No 4. Abril/Junho, 2006, p. 86 - 100.

BARRERA T., Alberto; MARCANO, Cristina. Hugo Chávez Sin Uniforme. Caracas: Ed. Melvin, 2006.

BARROS, Pedro. Governo Chávez e desenvolvimento: a política econômica em processo. São Paulo: PUC, 2007. Dissertação de Mestrado.

BATISTA, P. N. "A política externa de Collor: modernização ou retrocesso?" Política externa, V. I, n. 4, 1993.

BATISTA JR. Paulo N. Da crise internacional à moratória brasileira. Rio de Janeiro: Paz e Terra, 1988.

BATTAGLINI, Elena et al. Mercosul - Integração na América Latina e Relações com a Comunidade Europeia. São Paulo: Inca, 1993. 
BIELSCHOWSKY, Ricardo. (comp.) Sesenta años de la CEPAL: textos seleccionados del decenio 1998-2008. Buenos Aires: Siglo Veintiuno Editores, 2010.

BLOCH, Marc. Apologia da História. Rio de Janeiro: Jorge Zahar, 2002.

CALDEIRA, Giovana F. H. As relações políticas e econômicas entre Brasil e Espanha da transição democrática a nossos dias. IFCH/UNICAMP, 2008. Dissertação de Mestrado.

CAPELATO, Maria H. R. "História Política”. In: Revista Estudos Históricos, Vol. 9, № 17, Rio de Janeiro: CPDOC/FGV, 1996.

História do Tempo Presente: a Grande Imprensa como fonte e objeto de estudo. Rio de Janeiro: Ed. FGV, no prelo.

CARDOSO, Fernando H. A Arte da Política - A História que vivi. $3^{\mathrm{a}}$ Ed., Rio de Janeiro: Civilização Brasileira, 2006.

CARNEIRO, Maria C. R. O Governo Collor-1990-1994. São Paulo: Editora Três, 1999.

CERVO, Amado L. As relações históricas entre o Brasil e a Itália: o papel da diplomacia. Brasília: Editora Universidade de Brasília; São Paulo: Instituto Italiano di Cultura, 1992

(org.) O Desafio Internacional: a política exterior do Brasil de 1930 a nossos dias. Brasília: Ed. UnB, 1994.

Relações Internacionais da América Latina: velhos e novos paradigmas. Brasília: IBRI, 2001.

. Relações Internacionais da América Latina: velhos e novos paradigmas. 2. Ed.

São Paulo: Saraiva, 2007.

Ática, 1992.

; BUENO, Clodoaldo. História da Política Externa do Brasil. São Paulo: Ed. História da Política Exterior do Brasil. 4. Ed. Brasília: UnB, 2011

CONSALVI, Simón Alberto. Una Política Exterior Democratica en Tiempos de Crisis, Caracas: Editorial Pomaire, 1988.

CONTI, Mario S. Notícias do Planalto: a imprensa e Fernando Collor. São Paulo: Companhia das Letras, 1999.

DUROSELLE, Jean-Baptiste. Todo Império Perecerá: teoria das relações internacionais. Brasília: UNB, 2000.

EMBAIXADA DA VENEZUELA NO BRASIL, Abriendo caminos para la historia: los viajes del presidente Caldera al Brasil. Caracas: Editorial Panapo, 1997. 
FLORENZANO, Modesto. "François Furet: Historiador da Revolução Francesa" Revista de História, no 132, São Paulo: USP, 1995, p. 95-109.

FURTADO, Celso. Ensaios sobre a Venezuela: subdesenvolvimento com abundância de divisas. Rio de janeiro: Contraponto: Centro Internacional Celso Furtado, 2008.

GALVÃO, Thiago G. Uma história de parceria: as relações entre Brasil e Venezuela (18102012). Belo Horizonte: Fino Traço, 2012.

GAUCHET, Marcel. Le désenchantément du monde: histoire politique de la religion. Paris: Gallimard, 1985.

GOMES, Luiz Marcos. Os homens do Presidente. São Paulo: Viramundo, 2000.

GUERREIRO, Ramiro S. Lembranças de um empregado do Itamaraty. São Paulo: Siciliano, 1992.

GUIMARÃES, Samuel P. (org.). Brasil e Venezuela: esperanças e determinação na virada do século. Brasília: Instituto de Pesquisa de Relações Internacionais: Fundação Alexandre de Gusmão, 1995.

; CARDIM, Carlos H.(orgs.). Venezuela: Visões Brasileiras, Brasília: FUNAG, 2001.

HAGE, José A. A. As Relações entre Argentina e Brasil no Mercosul: princípios de hegemonia, dependência e interesse nacional no Tratado de Assunção. Dissertação de Mestrado. Campinas: IFCH/Unicamp, 2001.

HITNER, Verena. Uma análise do malogro do modelo de desenvolvimento latino-americano dos anos 1990: os limites internos da Venezuela. São Paulo: USP, 2011. Dissertação de Mestrado.

JAKOBSKIND, Mário A. América Latina: histórias de dominação e libertação. Campinas: Papirus, 1985.

KUNZLER, Jacob P. Mercosul e o Comércio Exterior. $2^{\mathrm{a}}$ Ed. São Paulo: Aduaneiras, 2002.

LAFER, Celso. Mudam-se os tempos: Diplomacia Brasileira - 2001/2002. Vols. I e II. Brasília: IPRI: FUNAG, 2002.

LAMOUNIER, Bolívar (org.). De Geisel a Collor: o balanço da transição. São Paulo: Ed. Sumaré, 1990

LAMPREIA, Luiz F. O Brasil e os ventos do mundo, Rio de Janeiro: Objetiva, 2010.

LOSS, Mônica V. Os condicionantes econômicos e políticos no relacionamento BrasilVenezuela de 1990-1998. Dissertação de Mestrado. Porto Alegre: UFRGS, 2007. 
MANDUCA, Paulo C. S. As Relações Brasil-África do Sul. IFCH/Unicamp, 1995. Dissertação de Mestrado.

MARINGONI, Gilberto. A Venezuela que se inventa: poder, petróleo e intriga nos tempos de Chávez. São Paulo: Ed. Fundação Perseu Abramo, 2004.

. A Revolução Venezuelana. São Paulo: UNESP, 2008.

MELLO, Leonel I. A. Brasil e Argentina em Perspectiva. Revista de História. No 147. 2002. P. $211-234$.

MENDES, Flávio da Silva. Hugo Chávez em seu labirinto. O movimento bolivariano e a política na Venezuela. São Paulo: Alameda/Fapesp, 2011.

MENDIBLE ZURITA, Alejandro. Venezuela-Brasil: La Historia de Sus Relaciones Desde Sus Inicios Hasta El Umbral del Mercosur (1500-1997), Caracas: FEPUVA, 1999.

. "Darcy Ribeiro" Cadernos de História da Educação. V. 10, n. 1, Curitiba: UFP, jan./jun. 2011, p. 33-50.

MILLET, Damien; TOUSS AINT, Éric. 50 perguntas 50 respostas sobre a dívida, o FMI e o Banco Mundial. São Paulo: Boitempo, 2006.

MONIZ BANDEIRA, Luiz A. Presença dos Estados Unidos no Brasil. Rio de Janeiro: Civilização Brasileira, 1973.

. Estado nacional e política internacional na América Latina - O continente nas relações Argentina-Brasil (1930 - 1992), 2a ed., São Paulo: Ensaio, 1995.

. Conflito e integração na América do Sul-Brasil, Argentina e Estados Unidos: da Tríplice Aliança ao Mercosul (1870 - 2003). Rio de Janeiro: Revan, 2003.

Formação do Império Americano. Rio de Janeiro: Civilização Brasileira, 2005.

MOTA, Carlos G. (org.). Viagem Incompleta: A experiência brasileira. A Grande Transação. São Paulo: SENAC, 2000.

MOURA, Gérson. Autonomia na dependência; a política externa brasileira de 1935 a 1942. Rio de Janeiro: Nova Fronteira, 1980.

MUÑOZ, Heraldo; TULCHIN, Joseph S. (orgs.) Latin American Nations in World Politics. Boulder, EUA: Westview Press, 1996.

MURILLO VIAÑA, Fernando. América Latina en los Ochenta. Madri: Ediciones Cultura Hispánica, 1986.

NEVES, Rômulo F. Cultura política e elementos de análise da política venezuelana. Brasília, FUNAG, 2010. 
OLIVEIRA, Henrique A. Política Externa Brasileira, São Paulo: Saraiva, 2005.

; LESSA, Antonio C. (orgs.) Relações Internacionais do Brasil: temas e agendas. São Paulo: Saraiva, 2006

PORTILLO, Julio. Venezuela-Brasil - Relaciones Diplomaticas 1842-1982. Caracas: Ed. Arte, 1983.

PRADO, Maria Lígia C. O Brasil e a distante América do Sul. Revista de História. N $^{\circ} 145,2^{\circ}$ semestre de 2001. São Paulo: Humanitas, USP, 2001.

RÉMOND, René (org.). Por uma história política. Trad. Dora Rocha. 2 ed. Rio de Janeiro: Editora FGV, 2003.

RENOUVIN, Pierre; DUROSELLE, Jean-Baptiste. Introduction à l'histoire des relations internationales. $4^{\mathrm{a}}$ ed., Paris: Armand Colin Éditeur, 1991.

ROSANVALLON, Pierre. A crise do Estado-providência. Tradução de Joel Ulhoa. Goiânia: UFG, 1997.

ROSANVALLON, __ Por uma história do político, São Paulo: Alameda, 2010.

SALLUM JR., Brasílio; CASARÕES, Guilherme S. P. "O impeachment do presidente Collor: a literatura e o processo". In: Lua Nova, São Paulo, no 82, 2001.

SANTOS, Marcelo. O poder norte-americano e a América Latina no pós-guerra fria. São Paulo: Annablume; Fapesp, 2007.

SANTOS, Theotonio dos. A Teoria da Dependência: Balanços e Perspectivas. Rio de Janeiro: Civilização Brasileira, 2000.

SARAIVA, José F. S. (org.). História das Relações Internacionais Contemporâneas. São Paulo: Saraiva, 2007.

SARDENBERG, Ronaldo M. As Relações Brasil-Europa. In: BAHIA, Luiz A. Questões críticas da situação internacional. Brasília: Ed. UnB, 1982.

SECCO, Lincoln. História do PT. Cotia, SP: Ateliê Editorial, 2011

SOARES, Gabriela P. Projetos políticos de modernização e reforma no Peru: 1950-1975. São Paulo: Annablume: FAPESP, 2000.

; PINTO, Júlio P. A América Latina no universo das edições brasileiras. In: Diálogos, Vol. 8, N. 2, Departamento de História e do Programa de Pós-graduação da Universidade Estadual de Maringá, 2004.

História das Ideias e mediações culturais: breves apontamentos. In: Cadernos de Seminários de Pesquisa, Vol. II, São Paulo: USP-FFLCH/Humanitas, 2011. 
SKIDMORE, Thomas E. Brasil: de Castelo a Tancredo. Rio de Janeiro: Paz e Terra, $4^{\text {a }}$ Ed., 1991.

UCHOA, Pablo. Venezuela: a encruzilhada de Hugo Chávez. Rio de Janeiro: Globo, 2003.

VILlA, Rafael A. D. Política externa na administração Hugo Chávez. In: Política Externa, vol. 13, No 1, São Paulo: Paz e Terra, Junho/Julho/Agos to 2004.

Limites do ativismo venezuelano para América do Sul. In: Política Externa,

Vol. 16, Nº. 2. São Paulo: Paz e Terra, Setembro/Outubro/Novembro 2007.

Rafael Caldera (1916-2009) e a democracia: memória política de um estadista

latino-americano. In: Política Externa, Vol. 18, № 4. São Paulo: Paz e Terra, Março/Abril/Maio 2010.

Carlos Andrés Pérez (1921-2010), de líder regional ao impeachment. In: Política Externa, Vol. 19, No. 4. São Paulo: Paze Terra, Março/Abril/Maio 2011.

VIZENTINI, Paulo G. F. A política externa do Regime Militar brasileiro: multilateralização, desenvolvimento e a construção de uma potência média (1964 - 1985). Porto Alegre: Ed. UFRGS, 1998.

O descompasso entre as nações. Rio de Janeiro: Record, 2004.

; CARRION, Raul K. M. A crise do capitalismo globalizado na virada do milênio.

Porto Alegre: Editora da Universidade Federal do Rio Grande do Sul, 2000. 